\title{
Top management team impact on organizations: determinants from inside and outside the boardroom
}

Citation for published version (APA):

Raes, A. (2008). Top management team impact on organizations: determinants from inside and outside the boardroom. [Doctoral Thesis, Maastricht University]. Maastricht University. https://doi.org/10.26481/dis.20081114ar

Document status and date:

Published: 01/01/2008

DOI:

10.26481/dis.20081114ar

Document Version:

Publisher's PDF, also known as Version of record

\section{Please check the document version of this publication:}

- A submitted manuscript is the version of the article upon submission and before peer-review. There can be important differences between the submitted version and the official published version of record.

People interested in the research are advised to contact the author for the final version of the publication, or visit the DOI to the publisher's website.

- The final author version and the galley proof are versions of the publication after peer review.

- The final published version features the final layout of the paper including the volume, issue and page numbers.

Link to publication

\footnotetext{
General rights rights.

- You may freely distribute the URL identifying the publication in the public portal. please follow below link for the End User Agreement:

www.umlib.nl/taverne-license

Take down policy

If you believe that this document breaches copyright please contact us at:

repository@maastrichtuniversity.nl

providing details and we will investigate your claim.
}

Copyright and moral rights for the publications made accessible in the public portal are retained by the authors and/or other copyright owners and it is a condition of accessing publications that users recognise and abide by the legal requirements associated with these

- Users may download and print one copy of any publication from the public portal for the purpose of private study or research.

- You may not further distribute the material or use it for any profit-making activity or commercial gain

If the publication is distributed under the terms of Article $25 \mathrm{fa}$ of the Dutch Copyright Act, indicated by the "Taverne" license above, 
TOP MANAGEMENT TEAM IMPACt ON ORganizations:

Determinants from Inside and Outside the Boardroom

Anneloes M. L. Raes 
ISBN: 978-90-8891-0616

(c) 2008, A. M. L. Raes

Cover Design \& Artwork // E. Tode 2008

Printed by: Uitgeverij BOX Press, Oisterwijk 


\title{
Top MANAgement TEAM IMPACt ON ORganizations: \\ Determinants from Inside and Outside the Boardroom
}

\section{Proefschrift}

\author{
ter verkrijging van de graad van doctor \\ aan de Universiteit Maastricht, \\ op gezag van de Rector Magnificus, \\ Prof. Mr. G. P. M. F. Mols \\ volgens het besluit van het College van Decanen, \\ in het openbaar te verdedigen op \\ vrijdag 14 november 2008 om 14:00 uur
} door 


\section{Promotoren:}

Prof. dr. R. A. Roe

Prof. dr. M. G. Heijltjes

\section{Co-promotor:}

Dr. U. Glunk

\section{Beoordelingscommissie:}

Prof. dr. M. A. Carree (voorzitter)

Prof. dr. B. S. Lawrence (UCLA Anderson School of Management, United States)

Prof. dr. R. S. Peterson (London Business School, United Kingdom)

Prof. dr. F. R. H. Zijlstra 


\section{Dankwoord \& Acknowledgements}

Op deze ongetwijfeld meest gelezen pagina's van dit proefschrift wil ik een aantal mensen heel hartelijk bedanken voor hun directe of indirecte bijdrage aan het tot stand komen ervan.

In de eerste plaats mijn begeleiders van de Universiteit Maastricht, Rob Roe, Mariëlle Heijltjes en Ursula Glunk, voor de wetenschappelijke en persoonlijke begeleiding en het vertrouwen gedurende de afgelopen vier jaren. Rob, veel dank voor je steeds weer inspirerende gedachten, voorstellen en commentaar en de boeiende discussies. En bovendien voor het bewaken van de balans tussen het opstarten van leuke nieuwe projecten en het voltooien van het proefschrift. Mariëlle, dankjewel voor je enthousiasme, creativiteit en kritische blik en de leuke samenwerking aan de verschillende varianten van de studentenbesturen-studie. En, uiteraard, het 'lobster dinner' in de Harvard Faculty Club was onvergetelijk! Ursula, dankjewel voor je altijd scherpe commentaar, je betrokkenheid en de kansen die je me hebt gegeven op het gebied van onderwijs, zoals in het UNICEF project. Ook denk ik met veel plezier terug aan de productieve samenwerking in het middenmanagers-onderzoek en de casestudy, waarbij de lunches op zonnige terrasjes ongekende inspiratie bleken te geven.

I would also like to thank the members of the dissertation committee: prof. dr. Martin Carree, prof. dr. Barbara Lawrence, prof. dr. Randall Peterson, and prof. dr. Fred Zijlstra. Thank you for the time and energy that you devoted to reading this dissertation. Barbara, thank you also for your support and guidance when I was a visiting student at UCLA. Your seminars and classes have encouraged me to 'theorize' and to start a Maastricht-version of your successful PhD seminar.

De empirische studies van dit proefschrift waren niet mogelijk geweest zonder de medewerking van de managementteams en middenmanagers. In de eerste plaats gaat mijn dank uit naar de leden van het topmanagementteam dat ik gedurende een half jaar heb mogen observeren. Heel veel dank voor jullie vertrouwen om mij toe te laten bij vertrouwelijke vergaderingen, voor de tijd die jullie aan de interviews hebben besteed en voor jullie openheid die het mogelijk maakte deze studie gerapporteerd in hoofdstuk 4 - tot een succes te maken. Bovendien wil ik de besturen van de studentenverenigingen hartelijk bedanken voor de bereidheid om gedurende een jaar onze vragenlijsten in te vullen. De resultaten hiervan zijn te lezen in hoofdstuk 3. Ik had deze studie bovendien niet uit kunnen voeren zonder de medewerking van de scriptie-studenten die inmiddels vele bestuurskamers in heel Nederland van binnen kennen. Anouk Broen, Victor van der Linden, Susanne Simons en Liselotte Wentrup: veel dank voor jullie enthousiaste bijdragen en de prettige samenwerking.

I would also like to thank the people with whom I worked on projects not directly related to this dissertation, who broadened my scientific perspective and once more illustrated the fun and inspiration that can come from scientific cooperation. Woody van Olffen, Boris Blumberg, and Yun Chung, thank you for the synergetic collaboration on the faultlines-study; Mary Waller, Rob Roe, Seth Kaplan, and Josette Gevers, thank you for the chance to work with you on the 'bifurcation' paper. 
Woody, thanks also for your coaching and advice on both scientific and personal matters. Mary, thank you for the insights gained during our cooperation and for sharing your experiences and advice regarding American academic life.

At Harvard University, I would like to thank Richard Hackman, Anita Williams Woolley, and Claudia Peus, for providing me with the opportunity to work in the Group Brain Project and develop my top management team research. At UCLA, I would like to thank the PhD students Priya KannanNarasimhan, Vicki Scherwin, Ning Chen, Neha Shah, Shalini Lal, and Hilla Dotan for making my time in Los Angeles both useful and very enjoyable.

Omar Solinger and Jia Li, my office mates, I had a great time with you and I would like to thank you for being able to deal with my 'time urgent' work-rhythm, your nice company, and our discussions about life and science. In addition, I would like to thank all current and former PhD students of the Organization and Strategy department - among which: Fons Naus, Sara Safay, Jacqueline Pennings, Stefanie Lorenz-Orlean, Hans Frankort, Maarten Cuijpers, Sjir Uitdewilligen, Daniela Kirchberg, and Sara Horn - for both social and scientific support during the PhD seminars, over lunches and coffees, in the train, while running, and on many other occasions. The other current and former members of the department of Organization and Strategy also deserve a big thank you for maintaining an enjoyable and supportive working environment.

Dan zijn er de mensen van buiten de universiteit, mijn familie en vrienden, die niet per se inhoudelijk, maar juist des te meer persoonlijk betrokken waren bij dit proefschrift. Jullie aanwezigheid en interesse, zowel live als per telefoon of Skype, gaven mij altijd weer nieuwe energie, afleiding en ideeën. In het bijzonder wil ik hierbij diegenen noemen die al sinds lang mijn leven máken: mijn ouders, Carolijn, Michiel, Michiel S., paranimfen Sanne en Simone, mijn vriendinnen en vrienden van het Newman en die 'uit' Nijmegen. En ook al diegenen die ik hier niet bij naam noem: jullie gezelschap en betrokkenheid zou ik niet kunnen missen; ook niet wanneer ik weer eens een tijdje in het buitenland ben!

Ten slotte is er Matthijs, die gelukkig altijd weer een nieuw perspectief op 'mijn soort' wetenschap wist in te brengen en zonder wie de afgelopen jaren zonder twijfel niet zo mooi waren geweest als nu het geval was. Matthijs: dankjewel voor je grenzeloze steun en inspiratie op alle mogelijke gebieden.

Anneloes 


\section{Contents}

Dankwoord \& Acknowledgements

Chapter 1 Introduction 1

What Is a Top Management Team? 2

Theories about Top Management Teams $\quad 4$

Research Gaps $\quad 6$

Dissertation Outline $\quad 8$

Chapter 2 What Happens in the Boardroom? A Review on the Effects of Top 11

Management Team Internal Processes and Emergent States on

Outcomes

Introduction 12

A Framework for Organizing Research on TMT Internal Processes 13

$\begin{array}{ll}\text { Method } & 18\end{array}$

Results $\quad 41$

Implications for Future Research $\quad 57$

Conclusion $\quad 59$

Chapter 3 Temporal Patterns of Conflict and Trust in Management Teams 61

Introduction 62

Theoretical Background $\quad 63$

Hypotheses $\quad 66$

$\begin{array}{ll}\text { Method } & 70\end{array}$

$\begin{array}{ll}\text { Results } & 74\end{array}$

$\begin{array}{ll}\text { Discussion } & 79\end{array}$

Conclusion $\quad 83$

Appendix $\quad 84$

Chapter 4 Top Management Team and Middle Managers: Making Sense of 85

Leadership

Introduction $\quad 86$

$\begin{array}{ll}\text { Method } & 88\end{array}$

Results and Discussion $\quad 92$

$\begin{array}{ll}\text { Conclusion } & 103\end{array}$ 
Chapter 5 The Dimensionality of Top Management Team Performance:

Expectations and Evaluations of Middle Managers

Introduction

$\begin{array}{ll}\text { Theoretical Background } & 107\end{array}$

Research Questions 112

Method 113

$\begin{array}{ll}\text { Results } & 116\end{array}$

Discussion 123

Conclusion 126

Chapter 6 The Interface of Top Management Team and Middle Managers: 127 A Process Model

$\begin{array}{lr}\text { Introduction } & 128 \\ \text { Theoretical Background } & 129 \\ \text { The Interface Model } & 132 \\ \text { Discussion and Implications } & 141 \\ \text { Conclusion } & 145\end{array}$

$\begin{array}{lr}\text { References } & 147\end{array}$

$\begin{array}{ll}\text { Summary } & 161\end{array}$

$\begin{array}{ll}\text { Samenvatting } & 163\end{array}$

$\begin{array}{ll}\text { About the Author } & 166\end{array}$ 


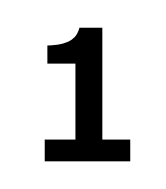

\section{Introduction}

Top management teams (TMTs) are assumed to matter for their organizations. Yet, how these teams exert their impact is unclear. This dissertation addresses this question by investigating two types of determinants of TMT impact. First, we study the role of what happens inside the boardroom by examining the role of TMT internal processes and emergent states for team and organizational outcomes. Second, we focus on what happens outside the boardroom, in the interface of TMT and middle managers. In this first chapter, the key concepts of the dissertation are defined, two theoretical perspectives are introduced, and the outline of the further chapters is presented. 
A widespread assumption in both organizational literature and business practice is that the performance of organizations is influenced by their top managers. Although heroic images of single Chief Executive Officers (CEOs) who steer organizations according to a 'one-captain-on-a-ship approach' still abound in the media and the business press, organizational reality is that many organizations nowadays have a top management team (TMT) instead of a single decision-maker at the top (Cohen \& Bailey, 1997; O'Toole, Galbraith, \& Lawler, 2002; Wageman, Nunes, Burruss, \& Hackman, 2008).

It has been established that TMTs somehow 'matter' for their organizations (Certo, Lester, Dalton, \& Dalton, 2006; Hambrick, 2007). However, the mechanisms by which such influence is exerted are less clear. TMT impact is the effect that the TMT has on the operation and outcomes of the organization and can be positive, negative, neutral, or even absent. The goal of this dissertation is to contribute to the scientific knowledge on TMTs by investigating determinants of TMT impact on their organizations.

In this chapter, I describe in more detail what TMTs are and why such teams exist at the top of organizations. Thereafter, I introduce existing research from paradigms in strategy and psychology that shed light on the issue of TMT organizational impact. Given my interest in understanding the phenomenon of TMTs operating in organizations and the state-of-the-art of current research, I identify gaps in scientific knowledge that currently hinder insight into TMT impact. Chapter 1 ends with an outline of the dissertation.

\section{What Is a Top Management Team?}

The concept of 'top management team' was introduced in the organizational literature more than twenty years ago by Hambrick and Mason (1984), who simply referred to it as "the firm's officers" (p. 196). These authors proposed to focus on demographic characteristics of TMT members as important determinants of why organizations act the way they do. More recently, a TMT was further specified to be the aggregate informational and decisional entity through which the organization operates and which forms the inner circle of executives who collectively formulate, articulate, and execute the strategic and tactical moves of the organization (Eisenhardt, Kahwajy, \& Bourgeois, 1997; Klenke, 2003). What a TMT is can be understood in more detail when considering its three components: 'top', 'management', and 'team'.

\section{Top}

The TMT is the group of managers highest in the organizational hierarchy. Such an organizational position implies that these managers have much freedom in the way they plan and execute their work, although they are held accountable by the board of directors (Forbes \& Milliken, 1999; Pettigrew, 1992). This place at the top also implies that aspects of TMT work differ from the work of teams operating on lower organizational echelons.

First, TMTs' tasks are more complex and varied than those of most other teams. TMT members must comprehend a great deal of vague, ambiguous, and often conflicting information and decide which tasks are most critical to perform (Edmondson, Roberto, \& Watkins, 2003; Hambrick, 1994). 
Second, a TMT is highly visible for others inside and outside the organization. Hence, its actions carry symbolic meaning and are particularly prone to be scrutinized by others (Ancona, 1989; Gibson \& Schroeder, 2003). Third, TMTs often consist of members from different parts of the organization, such that these managers are simultaneously part of the TMT and the head of their own business unit (Cohen \& Bailey, 1997; O'Toole et al., 2002). Thus, although TMTs might be comparable to nonmanagerial teams in some ways (see Cohen \& Bailey, 1997), the tasks they perform pose specific demands on their work.

\section{Management}

Carrying out 'management' has been defined as "deciding what to do and getting it done through and with other people by making the best use of the available resources" (Armstrong, 1999, p. 8). The tasks of top management in particular have been described as the formulation and implementation of strategic decisions in order to ensure the survival and growth of the organization (Guth \& MacMillan, 1986; Hambrick, 1994).

Strategic decision making consists of the choice of a particular course of strategic action and strategy implementation comprises the subsequent actions to make that strategy happen (Mintzberg, 1983; Nutt, 1986). The crafting of high quality strategic decisions and the successful implementation of these decisions are two important mechanisms by which a TMT influences organizational outcomes (Amason, 1996; Hambrick \& Mason, 1984; Mintzberg, 1983).

\section{Team}

Having a team at the top implies that the management task becomes the responsibility of more than one person. Not a single CEO, but two or more top managers work together to formulate and implement strategic decisions (O'Toole et al., 2002). A team can be defined as a collection of individuals who are interdependent in their tasks, who share responsibility for outcomes, who see themselves and who are seen by others as an intact social entity embedded in one or more larger social systems and who manage their relationships across organizational boundaries (Cohen \& Bailey, 1997; Hackman, 1987).

Reflecting on this definition of a team, researchers have sometimes expressed doubts about the actual 'teamness' of TMTs (Hambrick, 1994). For example, it has been stated that a TMT might be more accurately described as a co-acting group, in which the CEO and his or her direct advisors function as 'semi-autonomous barons', than as a real team (Hambrick, 1994, 2007). It has also been argued that the composition of the TMT might vary with the strategic decision that is at issue, further challenging the teamness of a TMT (Roberto, 2003).

On the other hand, recent research has indicated that many organizations in fact do have 'real teams' at the top (Wageman et al., 2008). A TMT can be seen as a real team, when it is a distinct organizational entity, has clear boundaries about who is in the team, is reasonably stable in membership over time, and in which TMT members are interdependent in their work (Hackman, 2002; Wageman et al., 2008). The prevalence of such teams also seems to expand in response to the turbulence and complexity of the current global business environment of many organizations (Cohen 
\& Bailey, 1997; Wageman et al., 2008). Consistent with this previous research, I am primarily interested in this dissertation in TMTs that do exist as real teams and have a 'teamness' to them.

\section{Why a Team at the Top?}

Working as a team instead of individually is generally the preferred option when work is too voluminous and too complex to be performed alone. Teams also have the advantage of being flexible in how they deploy and use their resources and they provide opportunities for team members to learn from one another to build a larger pool of knowledge and expertise for themselves (Hackman, 2002). This reasoning also applies to work at the top of organizations. Researchers have stated that the current organizational reality, at least in large organizations, is too complex for a single manager to oversee and that a division of tasks among TMT members in a team structure could overcome this (Edmondson et al., 2003; O'Toole et al., 2002).

More specifically, it has been proposed that by working in a TMT, the quality of strategic decisions can be increased, because multiple managers can apply more and more diverse perspectives to solve a problem (Hambrick \& Mason, 1984; Janis, 1982). The synthesis of these perspectives is expected to be superior to an individual's decision (Amason \& Mooney, 1999). The commitment of executives to implement decisions can increase through the understanding and acceptance generated by joint decision making processes (Amason, 1996; Korsgaard, Schweiger, \& Sapienza, 1995). In addition, having a TMT at the top instead of a single manager has the potential to improve communication and cooperation among executives from different subunits.

\section{Theories about Top Management Teams}

Despite the theoretical advantages of having a team at the top, effective TMT functioning is not self evident. Assuming that 'good' performance of a TMT translates into an organization performing well, researchers have been interested in specifying which characteristics of the TMT and its internal dynamics matter for organizational performance and how these matter. Two streams of research provide primary insight in these questions: research from the upper-echelons perspective in the strategy discipline and team research from the social and organizational psychology areas.

Scholars of strategy have studied TMTs from the perspective of the upper-echelons theory (Carpenter, Geletkanycz, \& Sanders, 2004; Hambrick, 2007; Hambrick \& Mason, 1984). This theory emphasizes the role of TMT composition in terms of TMT members' demographic characteristics, such as age or functional background, for explaining organizational performance. TMTs with demographically diverse members are proposed to have more capabilities for processing information than TMTs in which members are similar and this diversity is expected to benefit strategic decision making and organizational performance (Haleblian \& Finkelstein, 1993; Leifer \& Mills, 1996). Scholars of upper-echelons theory have also introduced a focus on financial organizational performance as the main outcome measure of interest for studying TMT organizational impact.

Despite much empirical work, the results of studies that link TMT composition to organizational performance are inconsistent and inconclusive (Carpenter et al., 2004; Certo et al., 2006; Priem, 
Lyon, \& Dess, 1999). Researchers have repeatedly concluded that considering TMT composition alone does not provide real insight in how TMTs influence organizational performance (Lawrence, 1997; Priem et al., 1999). Some have even proposed to "call a moratorium for the use of demographic variables as surrogates for psychological constructs" (Boal \& Hooijberg, 2000, p. 523).

As a reaction to these inconsistent findings, researchers have proposed to explore the so called 'black box' in order to uncover the mechanisms through which TMT composition influences organizational performance (Lawrence, 1997; Priem et al., 1999). In doing so, they have built on theories about nonmanagerial teams from social and organizational psychology. In these fields, the interactions between members of small groups have since long been of central interest (Bales, 1950; Hackman, 1987; McGrath, 1964; Steiner, 1972; Tuckman, 1965). Scholars in psychology have often used an input-process-output model of teamwork to explain team outcomes (Cohen \& Bailey, 1997; Hackman, 1987; McGrath, 1964), or used this model as a base for formulating more detailed, recursive, and time-based models (Ilgen, Hollenbeck, Johnson, \& Jundt, 2005; Marks, Mathieu, \& Zaccaro, 2001). According to the input-process-output model, team inputs, including TMT composition, shape team internal processes and emergent states that subsequently lead to outcomes of teamwork, such as performance.

In this dissertation, we are primarily interested in TMTs that function as real teams. Yet, even these TMTs are different from the nonmanagerial teams (e.g., work teams, parallel teams, project teams; Cohen \& Bailey, 1997) on which most of the psychological team research has been based. In particular, numerous researchers have noted that the type of task teams perform have implications for team functioning (McGrath, 1984; Steiner, 1972, Stewart, 2006). Some aspects of the TMT task that distinguish them from those of other teams, include the high technical, social, and political complexity, high ego involvement of team members, and the high visibility of the TMT and its outcomes to others inside and outside the organization (Ancona, 1989; Hambrick 1994). Since the tasks of a TMT are different from those of other teams and task type has an impact on the relationships in the input-process-output model, findings on nonmanagerial teams cannot be directly transferred to TMTs (Hambrick, 1994). However, since the real team TMTs that are the focus of this dissertation can still be characterized as 'teams', I assume that the general model of teamwork provides a meaningful starting point for investigating determinants of TMT impact.

Researchers from the social and organizational psychological disciplines have studied various aspects of team inputs, team processes, and team outputs (for reviews, see Cohen \& Bailey, 1997; LePine, Piccolo, Jackson, Mathieu, \& Saul, 2008; Stewart, 2006). For example, as input factors, the design, composition, tasks, and structure of teams have been studied, and as output factors multiple aspects of objective and self-perceived team effectiveness and performance have been identified. For the TMT literature, the concepts of team internal processes and team emergent states are particularly relevant. Team internal processes describe the nature of team members' interaction and behavior while working on achieving the team's goals (Marks et al., 2001; Smith et al., 1994), whereas team emergent states are the cognitive and affective modes of a team at a certain moment (Marks et al., 2001; Srivastava, Bartol, \& Locke, 2006). Both type of constructs can add understanding to how team inputs are transferred to outcomes. TMT researchers have studied both internal processes and emergent states, but the focus has been on studying processes as 
determinants of TMT outcomes and as potential mediators and moderators of TMT composition organizational performance relationships (Carpenter et al., 2004; Peterson, Smith, Martorana, \& Owens, 2003; Smith et al., 1994).

\section{Research Gaps}

Scholars in the field of TMT research have stated that studying TMT composition alone is not enough for explaining TMT impact on organizations. In particular, they have proposed to assess TMT internal processes and to identify other factors as determinants of TMT impact (Carpenter et al., 2004; Hambrick, 2007; Peterson et al., 2003). However, some problems in the current TMT literature can be identified that limit understanding of these issues, which are the starting points of this dissertation.

First, existing empirical studies on TMT internal processes are relatively scarce and there is no clear overview on the relationships between TMT internal processes and organizational outcomes (Hambrick, 2007; Peterson et al., 2003; Pettigrew, 1992). Reasons for this scarcity include the difficulty for researchers to get access to TMTs for highly confidential data (Pettigrew, 1992), to publish null results (Carpenter et al., 2004), and to obtain the dual skill set in both micro- and macroorganizational research that is required for this research (Hambrick, 2007). Additionally, since existing empirical research spans multiple disciplines and theoretical domains (Carpenter et al., 2004), the results of different studies are not always compatible and there is currently no overarching framework to integrate empirical knowledge.

Second, there is a lack of integration of different processes and emergent states into broader patterns of team behavior and a lack of knowledge on how such patterns develop over time. In the upper-echelons tradition, researchers have suggested to study temporal aspects of TMT processes and outcomes. (Cannella \& Holcomb, 2005; Carpenter et al., 2004). In psychological team research, theoretical models acknowledging temporality in team functioning and suggestions for researchers who want to empirically study these topics are growing in importance (Arrow, McGrath, \& Berdahl, 2000; Ilgen et al., 2005; Marks et al., 2001; Weingart, 1997). In particular, researchers have proposed to study joint patterns of processes and emergent states as a way to understand the complex dynamics of teams (Arrow et al., 2000; McGrath, Arrow, \& Berdahl, 2000). However, both in the upper-echelons tradition and in psychological team research, empirical progress in this direction is limited.

A third difficulty that limits researchers' understanding of TMT internal processes as determinants of TMT impact on organizations, is a methodological singularity that characterizes the research field of TMTs. Most studies have relied on databases and large-scale surveys and failed to achieve a realistic picture of how strategic decisions are made in real-world firms (Cannella \& Monroe, 1997; Carpenter et al., 2004; Samra-Fredericks, 2000). To circumvent the inherent problems with any single research method and data source, researchers have advocated the triangulation of research methods, data sources, and analysis approaches (Edmondson \& McManus, 2007; McGrath, 1964). In line with this recommendation, researchers have proposed to use qualitative data and methods to study TMTs and achieve 'realistic pictures' of TMT functioning 
(Carpenter et al., 2004; Peterson, Owens, Tetlock, Fan, \& Martorana, 1998; Peterson et al., 2003). However, empirical research using new methodologies is rare.

The fourth problem is the variety of outcome measures used in studying TMT impact. The majority of upper-echelons researchers has relied on indicators of financial organizational performance to assess the outcomes of TMTs' work (Carpenter et al., 2004) or have used characteristics of TMTs' strategic decisions as criteria of interest (Amason, 1996; Amason \& Mooney, 1999). When researchers started to incorporate TMT internal processes from psychological team research, they also started to adapt outcome criteria and defined indicators of TMT performance on the team level (Edmondson et al., 2003). Quite problematically, the observed effects of processes and emergent states vary with the outcomes chosen (Barrick et al., 2007; Elron, 1997). Therefore, the current variety of outcome measures limits the comparability of findings and, thereby, hinders clear insight in the role and operation of these processes.

A final problem of the current research on TMT impact is that the proposed determinants are mostly limited to factors that are internal to the TMT. That is, the main variables of interest - TMT composition and TMT internal processes - both relate to what is happening inside the boardroom, when TMT members work together to make strategic decisions. However, the way in which such strategic decisions are subsequently implemented by the TMT and exert their influence on the operation of the organization, has received considerable less attention (Hickson, Miller, \& Wilson, 2003). In order words, it is unknown what happens outside the boardroom, when TMT members interact with other organizational actors to achieve strategic decision implementation. Nor do researchers have insight in how what happens inside the boardroom transfers into what happens outside.

In sum, the following open issues in the current literature on TMT impact are identified: 1) lack of insight in the role of TMT internal processes as determinants of TMT impact on organizations, 2) no consideration of how various TMT internal processes and emergent states relate to each other and develop over time, 3) methodological singularity and a lack of studies providing realistic pictures of TMT internal processes, 4) ambiguity regarding the outcomes on which TMT internal processes are proposed to have effects, and 5) limited attention to what happens outside the boardroom where TMT members cooperate with other organizational actors on strategic decision implementation.

For both scholars and practitioners, it would be desirable to get more knowledge about these open issues in the literature. Such knowledge is scientifically valuable, because despite an accumulation of TMT studies during the past twenty years, scholars do not know very well how TMTs influence their organizations. As TMT research is an active field with many researchers from different disciplines, more clarity about the effects of TMT internal processes would provide more detailed explanations for TMT impact on organizations. From the perspectives of practicing TMTs, Human Resources professionals, executive recruiters, and consultants, knowledge about the determinants of TMT impact on organizational success could assist in developing guidelines for the hiring, training, or coaching of TMT members. 


\section{Dissertation Outline}

This dissertation is perhaps best characterized as a journey through TMT research. The path follows the intersection of the research fields of strategic upper-echelons theory and psychological team research to finally arrive at a surprising, new perspective for research on TMT impact.

The journey starts in chapter 2 and 3 with an investigation of the relation between TMT internal processes and outcomes. The inductive qualitative study in chapter 4 provides an unexpected new direction and leads to a focus on a previously neglected determinant of TMT impact: TMT leadership toward middle managers. Chapter 5 continues to follow this new road and examines the perspectives of middle managers on TMT performance.

Finally, chapter 6 represents the destination of the dissertation where the findings from previous chapters are integrated and a new theoretical model is presented. This 'interface model of TMT and middle managers' builds on and extends current knowledge about determinants of TMT impact. The contents of the chapters are outlined in more detail below.

\section{Chapter 2}

In this chapter, a review and critical evaluation is presented of the studies that investigated the effects of TMT internal processes on outcomes. To organize existing research, we ${ }^{1}$ propose to adopt the distinction between task processes, relationship processes, and team emergent states from psychological team research (Marks et al., 2001), and we classify investigated variables accordingly. The outcomes of team processes are categorized as organizational, TMT, or decisional. We propose that further progress in the area of TMT processes should investigate joint patterns of processes and emergent states over time.

\section{Chapter 3}

In this chapter, we studied the evolution of one task process (task conflict), one relationship process (relationship conflict), and one team emergent state (team trust) in relation to two measures of team effectiveness. To be able to study these constructs over the period of a year and to circumvent the problem of changes in team composition during this period, we chose for a sample of 41 management teams of student organizations in the Netherlands. Task conflict, relationship conflict, and trust were studied over a 10-month period with five measurement moments.

The results showed that two significantly different patterns exist for conflict- and trustevolution in teams over time: a stable pattern with low conflict and high trust and an unstable pattern in which conflict increased over time and trust decreased. The teams with the stable pattern were more effective than teams with the unstable pattern.

\footnotetext{
${ }^{1}$ When using 'we' in this dissertation, I designate myself and the co-authors with whom the various studies have been performed, who are mentioned at the beginning of each chapter.
} 


\section{Chapter 4}

Since researchers have called for the use of qualitative methods to get a more realistic picture of TMT work (Cannella \& Holcomb, 2005; Carpenter et al., 2004), this chapter presents the results of a qualitative and longitudinal study of one TMT. The goal of this study was theory building instead of theory testing. We used a grounded-theory approach (Strauss \& Corbin, 1998) to find out what stands out when observing TMT internal processes 'in action' and to see what previous research might have missed due to the inherent limitations of quantitative survey research.

For this study, observational data from 23 meetings of a TMT were analyzed together with data from interviews and archival sources. The results point at a so far neglected aspect of how TMT internal processes can have an impact on organizational performance, namely through influencing TMT sensemaking about leading middle managers, which is expected to shape actual TMT leadership vis-à-vis middle managers.

\section{Chapter 5}

In this chapter, we present a study on the expectations and evaluations of 251 middle managers from the Netherlands and France regarding their TMTs' performance. The aim of this study was to establish the dimensionality of TMT performance by assessing middle managers' expectations and evaluations of their TMT. Middle managers were chosen, because they are important stakeholders of a TMT and the assessment of stakeholders' evaluations has been proposed as an important criterion for team performance (Hackman, 1987, 2002).

The results of this study indicate the existence of five dimensions of TMT performance: company results, strategic leadership, connectedness, TMT unity, and moral leadership. Establishing the dimensionality of TMT performance contributes to developing more comprehensive models of TMT impact by specifying in more detail the outcomes of such models.

\section{Chapter 6}

Through the qualitative approach in the study reported in chapter 4, the interface of TMT and middle managers was identified as an important, yet neglected, determinant of TMT impact on organizational performance. Subsequently, in chapter 5 , it became clear that middle managers have expectations and evaluations about their TMT and we suggested that these could be consequential for middle managers' commitment and effort in the implementation of TMT decisions.

Therefore, chapter 6 presents a theoretical model about the interface of TMT and middle managers. This model extends the current state of TMT research by proposing 'interface mechanisms' as determinants of decision quality and commitment and, subsequently, organizational performance, beyond the effects of TMT composition and TMT internal processes. Thereby, we propose to broaden researchers' current focus on what happens inside the boardroom with a focus on what happens outside.

To summarize the open issues and related research questions addressed in this dissertation, an overview is presented in table 1.1 , together with the chapters in which these are covered. 
Table 1.1. Open issues in TMT literature and associated research questions of this dissertation

Open issue in the literature

1. What is the role of TMT internal processes as determinants of TMT impact on organizations?

2. How are different TMT processes and emergent states inter-related over time?

3. Which internal processes can we see when observing TMTs with a qualitative approach; has anything been overlooked so far?

4. Can dimensions of TMT performance be organized in a comprehensive framework?

5. Which mechanisms that happen outside the boardroom describe the interface of TMT and middle managers?
Research question

Chapter

How can existing studies on TMT

internal processes be organized in a comprehensive framework?

- How do TMT internal processes and emergent states relate to outcomes on various levels?

- Do teams exhibit distinguishable patterns of conflict and trust over time?

- $\quad$ Are patterns of conflict and trust related to team performance?

- $\quad$ When observing a TMT during meetings and interviewing the TMT members about their team's functioning, what can be seen regarding TMT internal processes?

- How does a TMT make sense of its leadership role vis-à-vis middle managers?

- Can middle managers' expectations and evaluations be organized according to dimensions of TMT performance?

- What is the dimensionality of TMT performance?

How does the interface of TMT and middle managers influence strategic decision quality and implementation commitment?

- What are the TMT- and middle manager-related determinants and consequences of the interface mechanisms? 


\section{2}

\section{What Happens in the Boardroom? \\ A Review on the Effects of Top Management \\ Team Internal Processes and Emergent States on Outcomes}

The internal processes of top management teams (TMTs) have been proposed to be crucial for understanding the impact TMTs can have on their organizations. Despite empirical progress, insight into the importance of these processes for outcomes is limited due to conceptual and theoretical fragmentation within the field. This chapter presents a framework to organize existing research, as well as a review of the theoretical arguments and empirical findings on the relationship between TMT internal processes and outcomes. The results show that task processes, relationship processes and emergent states all relate to outcomes, but that inconsistent findings hinder further progress. Suggestions for future research in this area include examining the nature of TMTs, studying the temporal nature of processes and states, and performing integrative research that considers the simultaneous occurrence of multiple processes and their joint effect on outcomes.

This chapter is based on:

Raes, A. M. L., Roe, R. A., Glunk, U., \& Heijltjes, M. G. What happens in the boardroom? A review on the effects of top management team internal processes and emergent states on outcomes. Manuscript submitted for publication. 


\section{Introduction}

Strategic decision making at the top of organizations has increasingly been acknowledged to be a collective activity (Hambrick \& Mason, 1984; O'Toole, Galbraith, \& Lawler, 2002; Yukl, 2006). The 'top management team' (TMT), the group of top managers that steers decision making and implementation, has attracted the interest of scholars of strategy and decision making for the past decades. Although TMT composition was initially considered to be a direct determinant of TMT impact on organizations (Hambrick \& Mason, 1984), researchers have become increasingly interested in the mechanisms by which TMT composition leads to organizational outcomes (Carpenter, Geletkanycz, \& Sanders, 2004; Lawrence, 1997; Smith et al., 1994). One such mechanism is the interaction of TMT members toward each other during TMT taskwork, often referred to as 'TMT internal processes'.

TMT internal processes describe the nature of team members' interaction and behavior while working on achieving the TMT's goals (Marks, Mathieu, \& Zaccaro, 2001). These processes are referred to as 'internal' as they designate actions taking place among TMT members and exclude acts that take place in interaction with others, who are not part of the TMT. Consistent with a general input-process-output model of teamwork, TMT processes have been advocated as moderators and mediators between TMT composition and outcomes (Hackman, 1987; McGrath, 1984), and as crucial for understanding how, when, and why TMT composition matters for organizational outcomes (Carpenter et al., 2004; Hambrick, 2007).

Despite the now common agreement that studying TMT internal processes would contribute to a better understanding of TMTs' impact on their organizations (Carpenter et al., 2004), doing so empirically is a challenge. Empirical studies are relatively scarce, because getting access to TMTs for sensitive and confidential data is difficult (Hambrick, 2007; Pettigrew, 1992) and because studying the effects of TMT processes on organizational performance requires a "dual skill-set in both microand macro-organizational research" (Hambrick, 2007, p. 337). An additional difficulty for researchers interested in TMT internal processes is that existing empirical research spans multiple disciplines and theoretical domains, such as strategy, organizational behavior, and psychology. As a result, a clear overview of the current state-of-the-art of research on TMT processes and outcomes is lacking.

The aims of this review are fourfold: 1 ) to provide a framework for organizing existing studies on TMT internal processes, 2) to identify what is currently known about how TMT internal processes relate to outcomes, 3) to assess what is currently unclear regarding the effects of TMT processes on outcomes, and 4) to present suggestions for advancing research on the role of TMT processes. The review covers the intersection of the field of upper-echelons theory and team research. As such, it relates to two previous review articles. We extend Carpenter and colleagues' (2004) review on upper-echelons theory by zooming in on the role of TMT internal processes, a topic that they touched upon, but could not explore in detail; we also build on Cohen and Bailey's (1997) review on teams, but do not systematically review the research on nonmanagerial teams.

In the following, we will first outline our model for organizing existing studies on TMT internal processes. This model builds on a general input-process-output model of teamwork (Cohen \& Bailey, 1997; Hackman, 1987; McGrath, 1964) and incorporates recent conceptual insights that distinguish 
team processes from emergent states (Marks et al., 2001). While using this framework, our focus is primarily on the relationship between processes and outcomes, leaving aside the effects of inputs most notably TMT composition - on processes. We have chosen to do so, because we reasoned that a first prerequisite for using internal processes as mechanisms of TMT impact is to establish a clear relationship between these processes and outcomes. We analyze the results from these studies to see what is known and what is unclear regarding the relationship between TMT processes and outcomes, and we conclude with formulating suggestions for further research on TMT internal processes.

\section{A Framework for Organizing Research on TMT Internal Processes}

Since Hambrick and Mason in 1984 introduced the term 'top management team', these authors' upper-echelons theory has been the major theoretical perspective for understanding how and why TMTs influence organizational performance (Carpenter et al., 2004; Hambrick, 2007; Hambrick \& Mason, 1984). According to this theory, diversity in demographic characteristics of TMT members enhances the information-processing capabilities of the TMT and, hence, benefits strategic decision making and, ceteris paribus, organizational performance (Haleblian \& Finkelstein, 1993; Leifer \& Mills, 1996). Although upper-echelons theory has succeeded in showing that the demographic profiles of executives 'matter' for organizational performance (Carpenter et al., 2004; Hambrick, 2007), a recent meta-analysis concluded that it is difficult to pinpoint the effects of individual demographic variables (Certo, Lester, Dalton, \& Dalton, 2006). This meta-analysis indicated that while significant relationships exist between TMT composition - in terms of team members' demographic characteristics - and organizational performance, "results do not hold across the TMT indicators, nor do they hold across the performance indicators; as importantly, those relationships that are significant indicate relatively modest associations between the relevant TMT indicators and firm performance" (Certo et al., 2006, p. 829). Other scholars have even proposed to "call a moratorium for the use of demographic variables as surrogates for psychological constructs" (Boal \& Hooijberg, 2000, p. 523).

As a result of these conflicting empirical findings, upper-echelons theory has been criticized for having created a 'black box', prohibiting insight in psychological and social mechanisms that link TMT members' characteristics to outcomes (Lawrence, 1997; Priem, Lyon, \& Dess, 1999). The interaction among top managers during taskwork ${ }^{1}$, often simply equated to strategic decision making, was proposed to be one such neglected mechanism and researchers started to use the generic term 'TMT processes' to designate aspects of this interaction. TMT internal processes have been proposed as both mediators and moderators of the relationship between TMT composition and outcomes (Carpenter et al., 2004).

When researchers started to acknowledge the importance of TMT internal processes and incorporated them in empirical research, they drew on approaches from related research fields to

\footnotetext{
${ }^{1}$ The overall tasks of a TMT can be described as strategic decision making and implementation (Hambrick \& Mason, 1984; Roberto, 2003; Srivastava, Bartol, \& Locke, 2006). Their tasks have been characterized as consisting of "unstructured task streams" (Edmondson et al., 2003), "a great deal of vague, ambiguous, and often conflicting information" (Edmondson et al., 2003; Hambrick, 1994), and "uncertainty, complexity, competitive pressures" (Srivastava et al., 2006).
} 
analyze how TMT processes can influence outcomes (Boal \& Hooijberg, 2000; Smith et al., 1994). Most notably, they drew on knowledge about nonmanagerial teams from the fields of social and organizational psychology, where researchers have since long been interested in the interactions between members of small groups (Bales, 1950; Cohen \& Bailey, 1997; Hackman, 1987; McGrath, 1964; Steiner, 1972; Tuckman, 1965). The basic input-process-output model of teamwork provided a meaningful framework for incorporating both TMT composition from upper-echelons research as well as TMT internal processes as determinants of TMT and organizational performance (Cohen \& Bailey, 1997; Hackman, 1987; McGrath, 1964). According to this model, team inputs, such as TMT composition and structure, shape interaction processes that subsequently lead to outcomes of teamwork. Our framework to categorize the TMT studies in this review, depicted in figure 2.1, also follows the input-process-output model.

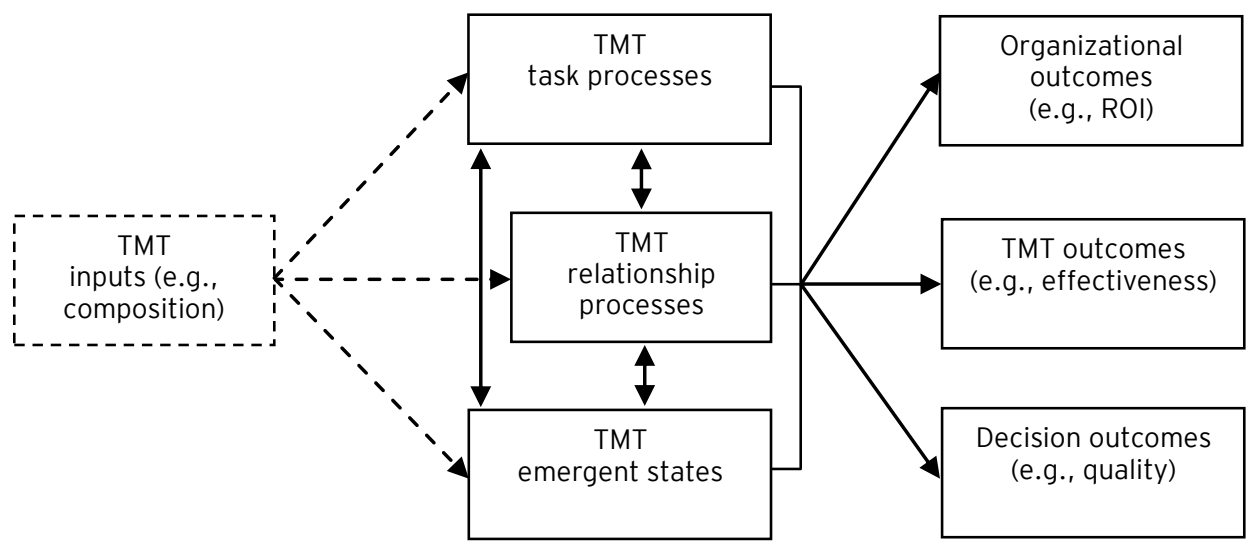

Figure 2.1. Conceptual framework for organizing studies on TMT internal processes (dashed arrows indicate relationships not covered in this review)

The input-process-output model of teamwork is applicable to understanding TMT work, as TMTs are similar to nonmanagerial teams in that they have to combine the inputs of multiple individuals (such as TMT members' individual information, values, and experiences) during interaction and coordination processes, which result in certain outcomes (such as strategic decisions). However, the specific findings within this input-process-output model from research on nonmanagerial teams might not be directly transferable to TMTs, for several reasons (Hambrick, 1994). First, the tasks of a TMT are different from those of other types of teams, in that the TMT task is highly complex, dynamic, and uncertain (Ancona, 1989; Edmondson, Roberto, \& Watkins, 2003; Hambrick, 1994) and task characteristics may moderate relationships between team inputs, processes, and outcomes (Stewart, McGrath, 1984). Second, the presence and relevance of certain processes and states has been proposed to vary with the activities teams perform (Marks et al., 2001). Thus, processes and 
states that play a role in the interaction of nonmanagerial teams might not be relevant for generating TMT outcomes and, conversely, processes and states that would be important for understanding TMT outcomes might not have been covered by research on other types of teams. Third, TMTs comprise team members with very specific characteristics and this may influence the relationship between TMT inputs and processes. For example, TMT members have been argued to be "relatively aggressive and achievement-oriented" (Hambrick, 1994, p. 176) and to display different priorities, languages, and values because they come from different parts of an organization (Ancona, 1989; Hambrick, 1994). In this context, power and status dynamics can be expected to play a larger role in TMT processes than in other teams (Finkelstein, 1992).

\section{TMT Internal Processes and Emergent States}

In the first study that empirically investigated the role of TMT internal processes of Smith and colleagues (1994), the basic model for the role of TMT processes for explaining outcomes proved valid. The authors found support for their hypothesized 'intervening model' in which processes mediated the relationship between TMT demographic composition and organizational performance. They also found support for a 'process model', in which processes contributed incrementally beyond TMT composition to explaining organizational performance (Smith et al., 1994). In contrast, no support was found for a 'demography model', in which only TMT composition was a determinant of organizational performance without any effects of processes. This finding was later confirmed in another study that also explicitly compared the roles of TMT composition and processes in explaining outcomes. The model in which processes partly mediated the effects of TMT composition on strategic consensus showed superior fit above 'direct effects only' and 'full mediation by TMT processes' models (Knight et al., 1999). Thus, including TMT internal processes in research models seemed to explain TMT impact on organizational performance beyond the effects of TMT composition.

In subsequent studies on TMT processes, a variety of constructs has been used to represent processes, among which such conceptually diverse ones as communication (Smith et al., 1994), conflict (Amason, 1996; Barsade, Ward, Turner, \& Sonnenfeld, 2000), knowledge sharing (Srivastava et al., 2006), and cohesion (Elron, 1997). These constructs were often adapted from studies on nonmanagerial teams and adapted to fit to the particular tasks and work context of TMTs. The many new constructs that got introduced to this newly established research area at the intersection of upper-echelons theory and team research can be seen as an indication that this area is currently 'intermediate theory research' (Edmondson \& McManus, 2007). A problem commonly encountered in research in this phase, is that existing constructs lack reliability and external validity (Edmondson \& McManus, 2007). This seems to also be the case for the field of TMT processes where the broad variety of constructs that capture TMT internal processes has contributed to conceptual inconsistency regarding the nature of TMT processes.

A possible way to organize this variety of constructs comes from psychological research on nonmanagerial teams, where researchers have recently started studying the complex, adaptive, and dynamic nature of teams and paid attention to temporal and multi-level aspects of team functioning (Arrow, McGrath, \& Berdahl, 2000; Ilgen, Hollenbeck, Johnson, \& Jundt, 2005; Marks et al., 2001). To advance thinking about dynamic aspects of team functioning, a distinction has been made between 
team processes that describe characteristics of members' interaction, and team emergent states, which are cognitive and affective states of teams that vary as a function of team context, inputs, processes, and outcomes (Ilgen et al., 2005; Marks et al., 2001) ${ }^{2}$. For example, cohesion is a team emergent state as it reflects the extent to which TMT members are attracted to each other (Barrick, Bradley, Kristof-Brown, \& Colbert, 2007; Elron, 1997), whereas conflict is a process as it describes a characteristic of TMT members' interaction (Amason, 1996; Barsade et al., 2000). The distinction between processes and emergent states contributes to studying dynamic aspects of team functioning, because it provides conceptual clarity and because it models team states as both inputs and outcomes of team processes.

TMT researchers have also recently adopted the distinction between processes and emergent states, acknowledging that the two constructs capture fundamentally different aspects of TMT dynamics (Barrick et al., 2007; Srivastava et al., 2006). However, more emergent states had already been studied before without classifying them as such, and often under the label of TMT processes (Elron, 1997; Hendriks, 2004; Smith et al., 1994). Since processes and emergent states describe different aspects of TMT work that might relate differently to TMT outcomes, we analyze in this review all constructs that have been studied as TMT processes and see if these should be classified as processes or rather as emergent states.

\section{TMT Task and Relationship Processes}

TMT internal processes can be further classified as being primarily related to tasks or relationships. Task processes comprise the cognitive, verbal, and behavioral acts that describe TMT taskwork, such as task conflict, debate, and dissent (for examples of task processes, see Pitcher \& Smith, 2001; Rau, 2006; Simons, Pelled, \& Smith, 1999). Relationship processes are the affective, verbal, and behavioral acts that relate to TMT members relationships while working on their tasks, such as relationship conflict (for examples of relationship processes, see Amason, 1996; Amason \& Mooney, 1999; Amason \& Sapienza, 1997; Jehn, 1995).

The distinction between task and relational aspects of team interaction has been made in various ways in previous taxonomies of team interaction. For example, Bales (1950) in his Interaction Process Analysis of group dynamics distinguished between task and socio-emotional activities and Hackman (1987) distinguished between 'performance' and 'affective' aspects of team interaction. Research on communication and networks has identified 'instrumental' versus 'expressive' ties, where instrumental ties reflect the exchange of task-related information and expressive ties are 'affectIaden' and represent friendships (Balkundi \& Harrison, 2006; Reagans \& Zuckerman, 2001). Marks and colleagues (2001) make the distinction between taskwork, describing what teams do, versus teamwork, describing how they do it. Finally, in the literature on conflict, the distinction between 'task' and 'relationship' aspects of conflict is often used (De Dreu \& Weingart, 2003; Jehn, 1995; Simons \& Peterson, 2000). In the TMT literature, scholars with a strategic, upper-echelons perspective have traditionally emphasized task-related aspects of TMT interaction, such as strategic

\footnotetext{
${ }^{2}$ It should be noted that almost no research has explicitly focused on the stability or change of processes and states, so the extent to which team processes might change and states are 'emergent' is as yet unknown, as is the way in which processes and states influence each other over time.
} 
decision making (Carpenter et al., 2004; Hambrick, 2007), whereas the field of team research has served as a source of inspiration for constructs describing relational aspects of team dynamics.

Researchers who study task processes have typically focused on TMT information exchange as the central conduit for reaching strategic decisions. To come to a decision, top managers obtain, interpret, explain, and act on information from the environment (Amason, 1996; Dooley \& Fryxell, 1999; Leifer \& Mills, 1996). Since any single top manager has a limited field of vision and is subject to perceptual filters that influence perception and choice (Cyert \& March, 1963; Hambrick \& Mason, 1984; March \& Simon, 1958), researchers have argued that the exchange of information and perspectives among TMT members reduces the effects of such limits and enhances top management's ability to reach complex decisions. Accordingly, they have reasoned that TMT task processes characterized by differentiation in information and opinions will lead to the incorporation of more and more diverse information, the generation of creative ideas and multiple alternatives, and the application of the diverse skills and experience that TMT members possess (Edmondson et al., 2003; Olson, Parayitam, \& Bao, 2007). These processes are supposed to improve the quality of TMT decision outcomes (Amason \& Sapienza, 1997).

Researchers who study relationship processes have focused on time and energy as the main resources in TMT interaction. They often build on the underlying mechanism of minimizing 'process losses' in teamwork (Steiner, 1972) - coordination and motivation difficulties that waste or misapply members' time, energy, and expertise of which team performance suffers - and maximizing potential 'process gains'. For example, Smith and colleagues (1994) have reasoned that positive relationship processes limit coordination and control demands (i.e., monitoring behavior) for a team and, thus, result in better TMT performance. In contrast, when TMT interaction is characterized by tensions and animosities, TMT members' resources are distracted from taskwork and TMT performance will suffer (Amason, 1996; Amason \& Mooney, 1999; Simons \& Peterson, 2000).

Although task and relationship processes highlight conceptually distinct aspects of TMT interaction and operate according to different theoretical mechanisms, they are intimately connected. Task-related discussions during strategic decision making carry relational meanings and relationship processes permeate task behavior. Some researchers have argued that "it is entirely possible for groups to have high levels of both interpersonal attraction and task-oriented disagreement" (Forbes \& Milliken, 1999, p. 496) and that "effective strategic decision making teams are somehow able to synthesize the contradictory forces of dissent and consensus during the strategic decision-making process" (Dooley \& Fryxell, 1999, p. 389). Other research indicates that achieving optimal levels of task conflict - a task process - on one hand and relationship conflict - a relationship process - on the other, might in practice be difficult because the two tend to reinforce each other (De Dreu \& Weingart, 2003; Simons \& Peterson, 2000). We will provide insight in this apparent contradiction by analyzing which task and relationship processes have been studied and how they relate to outcomes.

\section{TMT Outcomes on Three Levels}

Most studies on TMT processes have included outcomes that refer to either the organizational, TMT, or decision level. Researchers in the upper-echelons tradition with the main objective of 
explaining organizational performance have typically used indicators of organizational performance as outcome measures: Return on Assets - ROA (laquinto \& Fredrickson, 1997), innovation (Chen, Liu, \& Tjosvold, 2005; Pitcher \& Smith, 2001; West \& Anderson, 1996), Return on Investment - ROI (Smith et al., 1994), growth, revenues, and profit (Ensley \& Pearce, 2001; Ensley, Pearson, \& Amason, 2002; Pitcher \& Smith, 2001) are some examples of these measures. A key strength of these indicators is that they are objective measures of TMT outcomes and scholars have suggested that organizational performance should be the ultimate criterion for TMT success (Cohen \& Bailey, 1997; Srivastava et al., 2006).

As outcomes on the TMT level, self perceptions of TMT members about the team's effectiveness, defined as the extent to which TMT members perceive that they have reached the TMT's goals, have been used (Flood et al., 2000). Additionally, Edmondson and colleagues (2003), referring to the literature on nonmanagerial teams (Hackman, 1987, 2002), proposed three TMT level indicators of team effectiveness: first, the degree to which the TMT's decisions enhance organizational performance; second, TMT members' commitment to implementing team decisions and willingness to work together in the future; and third, the extent to which the TMT process meets members' psychological needs for growth and satisfaction (see also Cohen \& Bailey, 1997, for more examples of team effectiveness measures from team research).

On yet another level, researchers have used characteristics of TMT strategic decisions as outcome measures. Examples are: decision quality (Amason, 1996; Carmeli \& Schaubroeck, 2006; Dooley \& Fryxell, 1999; Janssen, Van de Vliert, \& Veenstra, 1999), TMT members' acceptance of decisions (Amason, 1996; Janssen et al., 1999), and TMT members' commitment to implementing decisions (Amason, 1996; Dooley \& Fryxell, 1999; Olson et al., 2007). In this review, we will investigate whether the relationships between TMT processes and outcomes vary with different outcome measures. We distinguish between outcomes that relate to organizational performance (i.e., the various financial indicators), to the TMT (i.e., team effectiveness), and to characteristics of strategic decisions (i.e., quality, timeliness) ${ }^{3}$.

\section{Method}

We performed a structured literature search by using the Ebsco Business Premier and PsychArticles databases to identify studies that empirically investigated TMT internal processes and emergent states. From the articles that emerged from this search, we traced references to other articles that could be relevant to our purpose. We included articles that empirically investigated TMT processes and at least one outcome measure. Two studies have been included that did not incorporate outcome measures, but that specifically tested relationships among task processes, relationship processes, and emergent states (Knight et al., 1999; Simons \& Peterson, 2000). We took the study of Smith and colleagues (1994) as our starting point as this was the first to empirically investigate the role of TMT processes. As we focused on studies that related processes to outcomes, TMT studies that only

\footnotetext{
${ }^{3}$ For a more detailed perspective on the dimensionality of TMT performance, see chapter 5 of this dissertation. In the current chapter, we focus on existing outcome measures from the reviewed studies with the purpose of assessing the effects of TMT processes and emergent states on these outcomes.
} 
investigated the effects of TMT composition on TMT processes and/or outcomes have not been included in the review ${ }^{4}$.

For classifying investigated variables as task processes, relationship processes or emergent states, we based ourselves on the conceptualizations and operationalizations of the constructs. For example, when 'communication' was included as a variable (Smith et al., 1994), we analyzed the operationalization and measures that the authors used and concluded that this study's 'communication frequency' could be seen as a task process, as it referred to the frequency of TMT meetings. In contrast, their variable 'informal communication' was classified as a relationship process, because informality was seen as a relational aspect of interaction rather than primarily referring to taskwork. To make the distinction between processes and emergent states, we analyzed if the construct represented "TMT members' interdependent acts", or rather "qualities of a team that represent member attitudes, values, cognitions, and motivations" (Marks et al., 2001, p. 357), in which case the construct was classified as an emergent state. When in doubt about classifying a construct as a task or relationship process or emergent state, the scale items of the measure were the final criterion for our decisions.

\section{TMT Structure and the Teamness of TMTs}

Some variables in the studies we reviewed related to aspects of TMT dynamics that were not processes or emergent states, but rather represented structural characteristics of the TMT. Team structure is the relatively stable pattern of relationships among team members that determine the allocation of tasks, responsibilities, and authority (Forsyth, 1999; Stewart \& Barrick, 2000). Two important features of team structure are interdependence and team autonomy (Cohen \& Bailey, 1997; Stewart \& Barrick, 2000). Using this classification, we identified the constructs of 'TMT interdependence' (Barrick et al., 2007; Janssen et al., 1999) and 'decision centralization' (Hendriks, 2004) as characteristics of TMT structure. TMT structure has been proposed as a moderator for the relationship between TMT processes and outcomes (Barrick et al., 2007), and therefore, we analyzed the role of these variables as they could aid in achieving our primary goal of getting insight in how TMT internal processes and emergent states relate to outcomes ${ }^{5}$.

Related to TMT structure is the question to the 'teamness' of TMTs. Although the term 'top management team' has been used in scientific publications for more than twenty years, scholars have argued that TMTs might function rather as co-acting groups in which the CEO and direct advisors function as 'semi-autonomous barons' (Hambrick, 1994, 2007). Others have suggested that TMTs should be seen as flexible groups that include and exclude top executives depending on the specific decisions to be made (Roberto, 2003). This is in contrast to the description of an actual team as "a collection of individuals who are interdependent in their tasks, who share responsibility for outcomes,

\footnotetext{
${ }^{4}$ Some studies have investigated the internal processes of the TMTs from 'new venture' organizations. We choose to not include these studies, because of the inherent faultline between members from the two merging organizations that is present in such TMTs (Li \& Hambrick, 2005). This can be expected to lead to TMT internal processes that are qualitatively different from those in other TMTs.

${ }^{5}$ Team researchers have also studied TMT structure as an input (e.g., Stewart \& Barrick, 2000) or output (e.g., Langfred, 2007) variable to explain TMT internal processes and states. We report here the studies that incorporated team structure in a TMT setting, in which TMT structure was modeled as a moderator for the relationship of TMT processes and states to outcomes.
} 
who see themselves and who are seen by others as an intact social entity embedded in one or more larger social systems and who manage their relationships across organizational boundaries" (Cohen \& Bailey, 1997; Hackman, 1987). Hambrick $(1994,2007)$ argued that a TMT's teamness is enhanced when it is behaviorally integrated and when TMT members engage in mutual and collective interaction. A behaviorally integrated TMT shares information, resources, and decisions. Additionally, a TMT has been argued to be a 'real team' if it is interdependent in its work, has clear boundaries about who is in the team, and is reasonably stable in its membership over time (Hackman, 2002; Wageman, Nunes, Burruss, \& Hackman, 2008).

The teamness of TMTs might influence the relationships between TMT internal processes, emergent states, and outcomes. Internal processes might be different and have differential effects depending on the extent to which TMTs function as a real team versus as a co-acting group (Barrick et al., 2007). Although most studies did not explicitly measure variables that could indicate the degree of teamness of the TMTs in the samples, researchers have used multiple ways to identify the TMTs, such as selecting all managers above the level of vice-president or asking the CEO to identify the TMT (Certo et al., 2006; Cohen \& Bailey, 1997). Differences in selection method might serve as a coarse indicator of the extent to which the TMTs are real teams or not. When a TMT exists as a distinct social entity in an organization, it is likely to have more characteristics of a real team than a when researchers have identified TMT members by selecting top managers on the base of job titles. Therefore, we inspected in the reviewed studies how researchers had identified the TMTs by distinguishing between three options: the TMT was identified by the organization (i.e., the TMT existed as distinct social entity), by the CEO (i.e., a TMT could be identified, but it is not necessarily clear if this identified group of top managers functions as a distinct social entity or not), or by the researchers (i.e., researchers constructed a TMT based on job titles).

\section{Presentation of Review Results}

Table 2.1 presents the results of the search and classification process. We identified 27 studies that empirically investigated TMT processes and emergent states. The table provides an overview of the measured variables in the studies - classified as composition, structure, task processes, relationship processes, emergent states, and outcomes - the research methods and samples that were used, the identification of the TMTs - by the researchers, CEO, or organization, as well as the main results of the studies. To indicate significant relationships, we used the criterion that the results were at least significant at the level of $p<.05$. In the following, we will describe the characteristics of the studies included in the review and analyze the results. 
Table 2.1. Characteristics of empirical studies on TMT processes and emergent states in relation to outcomes

\begin{tabular}{|c|c|c|c|c|c|c|}
\hline $\begin{array}{l}\text { Author(s), } \\
\text { year of } \\
\text { publication, \& } \\
\text { journal of the } \\
\text { study }\end{array}$ & $\begin{array}{l}\text { TMT composition } \\
\text { (selection) \& TMT } \\
\text { structure }\end{array}$ & $\begin{array}{l}\text { TMT processes \& } \\
\text { emergent states }\end{array}$ & Outcome measures & Research methods & $\begin{array}{l}\text { Sample, TMT } \\
\text { identification, } \\
\text { \& average } \\
\text { TMT size }\end{array}$ & $\begin{array}{l}\text { Main results for } \\
\text { relationship TMT } \\
\text { processes and } \\
\text { emergent states to } \\
\text { outcomes }\end{array}$ \\
\hline $\begin{array}{l}\text { Amason } \\
(1996) \\
\text { Academy of } \\
\text { Management } \\
\text { Journal }\end{array}$ & $\begin{array}{ll}- & \text { TMT size } \\
- & \text { CEO tenure } \\
- & \text { Average team } \\
& \text { tenure }\end{array}$ & $\begin{array}{l}\text { Task process } \\
\text { - Cognitive } \\
\text { conflict } \\
\text { Relationship } \\
\text { process } \\
\text { - Affective } \\
\text { conflict }\end{array}$ & \begin{tabular}{ll}
\multicolumn{2}{l}{ Decision level } \\
$-\quad$ Decision \\
- $\quad$ quality \\
Understanding \\
of decision \\
- $\quad$ Commitment \\
to decision \\
- $\quad$ Affective \\
acceptance of \\
decision
\end{tabular} & $\begin{array}{l}\text { Questionnaires to } \\
\text { all team members } \\
\text { about one specific } \\
\text { strategic decision. } \\
\text { In sample 2: } \\
\text { additional semi- } \\
\text { structured } \\
\text { interviews }\end{array}$ & $\begin{array}{l}\text { 2 samples: } \\
\text { 1. } 48 \text { TMTs } \\
\text { from food } \\
\text { industry (USA) } \\
\text { 2. } 5 \text { TMTs } \\
\text { from } \\
\text { manufacturing } \\
\text { firms (USA) } \\
\text { TMT identified } \\
\text { by: } \\
\text { CEO } \\
\text { Average TMT } \\
\text { size sample 1: } \\
3.44 \\
\text { Average TMT } \\
\text { size sample 2: } \\
5\end{array}$ & $\begin{array}{l}\text { Analysis: multiple } \\
\text { regression analysis } \\
\text { * Cognitive conflict } \\
\rightarrow \text { decision quality: + } \\
* \text { Cognitive conflict } \\
\rightarrow \text { understanding: + } \\
\text { * Cognitive conflict } \\
\rightarrow \text { commitment: } n \text {. s. } \\
* \text { Cognitive conflict } \\
\rightarrow \text { affective } \\
\text { acceptance: + } \\
* \text { Affective conflict } \\
\rightarrow \text { decision quality: - } \\
* \text { Affective conflict } \\
\rightarrow \text { understanding: } n \text {. } \\
\text { s. } \\
* \text { Affective conflict } \\
\rightarrow \text { commitment: } n . \text { s. } \\
* \text { Affective conflict } \\
\rightarrow \text { affective } \\
\text { acceptance: - }\end{array}$ \\
\hline $\begin{array}{l}2 . \\
\text { Amason \& } \\
\text { Mooney } \\
\text { (1999) } \\
\text { International } \\
\text { Journal of } \\
\text { Conflict } \\
\text { Management }\end{array}$ & $\begin{array}{ll}- & \text { TMT size } \\
- & \text { CEO tenure }\end{array}$ & $\begin{array}{l}\text { Task process } \\
\text { - } \quad \begin{array}{c}\text { Cognitive } \\
\text { conflict }\end{array} \\
\text { Relationship } \\
\text { process } \\
\text { - Affective } \\
\text { conflict }\end{array}$ & 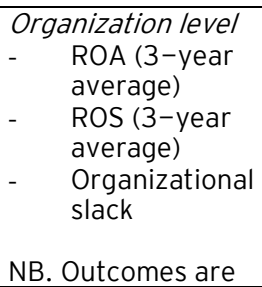 & $\begin{array}{l}\text { Questionnaires to } \\
\text { all team members } \\
\text { about one specific } \\
\text { strategic decision }\end{array}$ & $\begin{array}{l}44 \text { TMTs in } \\
\text { mid-size firms } \\
\text { from } \\
\text { computer } \\
\text { software and } \\
\text { restaurant } \\
\text { industry (USA) } \\
\text { TMT identified }\end{array}$ & $\begin{array}{l}\text { Analysis: multiple } \\
\text { regression analysis } \\
\text { Past performance } \rightarrow \\
\text { cognitive conflict: } \mathrm{n} \text {. } \\
\text { s. } \\
\text { Past ROA } \rightarrow \\
\text { affective conflict: - }\end{array}$ \\
\hline
\end{tabular}




\begin{tabular}{|c|c|c|c|c|c|c|}
\hline $\begin{array}{l}\text { Author(s), } \\
\text { year of } \\
\text { publication, \& } \\
\text { journal of the } \\
\text { study }\end{array}$ & $\begin{array}{l}\text { TMT composition } \\
\text { (selection) \& TMT } \\
\text { structure }\end{array}$ & $\begin{array}{l}\text { TMT processes \& } \\
\text { emergent states }\end{array}$ & Outcome measures & Research methods & $\begin{array}{l}\text { Sample, TMT } \\
\text { identification, } \\
\& \text { average } \\
\text { TMT size }\end{array}$ & $\begin{array}{l}\text { Main results for } \\
\text { relationship TMT } \\
\text { processes and } \\
\text { emergent states to } \\
\text { outcomes }\end{array}$ \\
\hline & & \begin{tabular}{ll}
\multicolumn{2}{c}{ Emergent states } \\
$-\quad$ Openness \\
norms \\
$-\quad$ Mutuality \\
norms
\end{tabular} & $\begin{array}{l}\text { studied as inputs } \\
\text { for conflict }\end{array}$ & & $\begin{array}{l}\text { by: } \\
\text { CEO } \\
\text { Average TMT } \\
\text { size: } \\
4.8\end{array}$ & $\begin{array}{l}\text { Past ROS } \rightarrow \text { affective } \\
\text { conflict: }- \\
\text { Past slack } \rightarrow \\
\text { affective conflict: } \\
\text { n. s. } \\
\text { Openness \& } \\
\text { mutuality norms } \rightarrow \\
\text { cognitive conflict: } \text { n. } \\
\text { s. } \\
\text { Mutuality norms } \rightarrow \\
\text { affective conflict: - } \\
\text { Openness norms } \rightarrow \\
\text { affective conflict: } \\
\text { n. s. }\end{array}$ \\
\hline $\begin{array}{l}\text { 3. Barrick, } \\
\text { Bradley, } \\
\text { Kristof- } \\
\text { Brown, \& } \\
\text { Colbert } \\
\text { (2007) } \\
\text { Academy of } \\
\text { Management } \\
\text { Journal }\end{array}$ & $\begin{array}{ll}- & \text { TMT size } \\
- & \text { Firm size } \\
- & \text { Firm age } \\
- & \text { TMT demographic } \\
\text { composition in } \\
\text { terms of tenure, } \\
\text { age, education, } \\
\text { sex } \\
\text { TMT structure } \\
\text { Interdependence }\end{array}$ & $\begin{array}{l}\text { Task process } \\
\text { Communication } \\
\text { Emergent states } \\
\text { Cohesion } \\
\text { NB. In analyses } \\
\text { communication and } \\
\text { cohesion combined } \\
\text { into one factor } \\
\text { 'team mechanisms' } \\
\text { (classified as task } \\
\text { process) }\end{array}$ & $\begin{array}{l}\text { TMT level } \\
\text { Team performance } \\
\text { (CEO rating) } \\
\text { Organization level } \\
\text { Organizational } \\
\text { performance (mean } \\
\text { of } 4 \text { measures } \\
\text { obtained with 1- } \\
\text { year time-lag: Net } \\
\text { worth to total } \\
\text { assets, delinquent } \\
\text { loans to total loans, } \\
\text { net charge-offs to } \\
\text { average loans, } \\
\text { return on average } \\
\text { assets (ROA). }\end{array}$ & $\begin{array}{l}\text { Questionnaires to } \\
\text { CEO and TMT } \\
\text { members }\end{array}$ & $\begin{array}{l}\text { 94 TMTs from } \\
\text { credit union } \\
\text { industry } \\
\text { (USA) } \\
\text { TMT identified } \\
\text { by: } \\
\text { CEO } \\
\text { Average TMT } \\
\text { size: } \\
6.4\end{array}$ & $\begin{array}{l}\text { Analysis: multiple } \\
\text { regression analysis } \\
\text { * Team } \\
\text { interdependence } \rightarrow \\
\text { team performance: - } \\
\text { * Team } \\
\text { interdependence } \rightarrow \\
\text { firm performance: - } \\
* \text { Team mechanisms } \\
\rightarrow \text { team } \\
\text { performance: - } \\
* \text { Team mechanisms } \\
\rightarrow \text { firm performance: } \\
\text { - } \\
\text { Team } \\
\text { interdependence } x \\
\text { team mechanisms } \rightarrow \\
\text { team performance: }+ \\
\text { Team }\end{array}$ \\
\hline
\end{tabular}




\begin{tabular}{|c|c|c|c|c|c|c|}
\hline $\begin{array}{l}\text { Author(s), } \\
\text { year of } \\
\text { publication, \& } \\
\text { journal of the } \\
\text { study }\end{array}$ & $\begin{array}{l}\text { TMT composition } \\
\text { (selection) \& TMT } \\
\text { structure }\end{array}$ & $\begin{array}{l}\text { TMT processes \& } \\
\text { emergent states }\end{array}$ & Outcome measures & Research methods & $\begin{array}{l}\text { Sample, TMT } \\
\text { identification, } \\
\text { \& average } \\
\text { TMT size }\end{array}$ & $\begin{array}{l}\text { Main results for } \\
\text { relationship TMT } \\
\text { processes and } \\
\text { emergent states to } \\
\text { outcomes } \\
\text { interdependence } x \\
\text { team mechanisms } \rightarrow \\
\text { firm performance: + }\end{array}$ \\
\hline $\begin{array}{l}4 . \\
\text { Barsade, } \\
\text { Ward, Turner } \\
\text { \& Sonnenfeld } \\
\text { (2000) } \\
\text { Administrative } \\
\text { Science } \\
\text { Quarterly }\end{array}$ & $\begin{array}{ll}\text { - } & \text { Positive affect } \\
\text { (PA) } & \\
\text { - } & \text { Perceived group } \\
\text { positive culture } \\
\text { - } \quad \text { CEO participative } \\
\text { leadership } \\
\text { (treated as } \\
\text { outcome \& judged } \\
\text { by team } \\
\text { members) }\end{array}$ & $\begin{array}{l}\text { Task processes } \\
\text { Task conflict } \\
\text { Relationship } \\
\text { process } \\
\text { Emotional conflict } \\
\text { Emergent state } \\
\text { TMT } \\
\text { cooperativeness }\end{array}$ & $\begin{array}{l}\text { Organizational } \\
\text { level } \\
\text { Market adjusted } \\
\text { return } \\
\text { NB. Also individual } \\
\text { level outcomes } \\
\text { included: } \\
\text { - interpersonal } \\
\quad \text { satisfaction } \\
\quad \text { within the } \\
\text { TMT } \\
\text { perceived } \\
\text { influence on } \\
\text { TMT }\end{array}$ & $\begin{array}{l}\text { Questionnaires } \\
\text { (distributed at } 2 \\
\text { CEO conferences) }\end{array}$ & $\begin{array}{l}62 \text { TMTs from } \\
\text { various } \\
\text { industries } \\
\text { (USA) } \\
\text { TMT identified } \\
\text { by: } \\
\text { CEO } \\
\text { Average TMT } \\
\text { size: } \\
4.41\end{array}$ & $\begin{array}{l}\text { Analysis: multiple } \\
\text { regression analysis } \\
\text { * Task conflict } \rightarrow \\
\text { market adjusted } \\
\text { return: } n \text {. s. } \\
\text { * Emotional conflict } \\
\rightarrow \text { market adjusted } \\
\text { return: } n \text {. s. } \\
\text { * TMT } \\
\text { cooperativeness } \rightarrow \\
\text { market adjusted } \\
\text { return: } n \text {. s. }\end{array}$ \\
\hline $\begin{array}{l}5 . \\
\text { Bunderson \& } \\
\text { Sutcliffe } \\
\text { (2003) } \\
\text { Journal of } \\
\text { Applied } \\
\text { Psychology }\end{array}$ & $\begin{array}{ll}- & \text { Market } \\
& \text { favorability } \\
- & \text { Team size } \\
- & \text { Average position } \\
& \text { tenure } \\
-\quad & \text { Position tenure } \\
& \text { heterogeneity } \\
-\quad & \text { Average industry } \\
& \text { tenure } \\
-\quad & \text { Industry tenure } \\
& \text { heterogeneity } \\
-\quad & \text { Functional } \\
& \text { background } \\
& \text { heterogeneity }\end{array}$ & $\begin{array}{l}\text { Task process } \\
\text { Communication } \\
\text { frequency } \\
\text { Emergent state } \\
\text { Team learning } \\
\text { orientation }\end{array}$ & $\begin{array}{l}\text { Organization level } \\
\text { - } \quad \text { Performance- } \\
\text { to-plan } \\
\text { - } \quad \text { Profit-per- } \\
\text { unit }\end{array}$ & Questionnaires & $\begin{array}{l}\text { 44 TMTs from } \\
\text { business units } \\
\text { from Fortune } \\
100 \text { consumer } \\
\text { products } \\
\text { company } \\
\text { (USA) } \\
\text { TMT identified } \\
\text { by: } \\
\text { Organization } \\
(\rightarrow \text { real teams) } \\
\text { Average TMT } \\
\text { size: } \\
11\end{array}$ & $\begin{array}{l}\text { Analysis: multiple } \\
\text { regression analysis } \\
\text { * Communication } \\
\text { frequency } \rightarrow \\
\text { performance-to- } \\
\text { plan: } \mathrm{n} \text {. s. } \\
\text { * Team learning } \\
\text { orientation } \rightarrow \\
\text { performance-to- } \\
\text { plan: - } \\
\text { Team learning } \\
\text { orientation }{ }^{2} \rightarrow \\
\text { performance-to- } \\
\text { plan: - } \\
\text { * Communication }\end{array}$ \\
\hline
\end{tabular}




\begin{tabular}{|c|c|c|c|c|c|c|}
\hline $\begin{array}{l}\text { Author(s), } \\
\text { year of } \\
\text { publication, \& } \\
\text { journal of the } \\
\text { study }\end{array}$ & $\begin{array}{l}\text { TMT composition } \\
\text { (selection) \& TMT } \\
\text { structure }\end{array}$ & $\begin{array}{l}\text { TMT processes \& } \\
\text { emergent states }\end{array}$ & Outcome measures & Research methods & $\begin{array}{l}\text { Sample, TMT } \\
\text { identification, } \\
\& \text { average } \\
\text { TMT size }\end{array}$ & $\begin{array}{l}\text { Main results for } \\
\text { relationship TMT } \\
\text { processes and } \\
\text { emergent states to } \\
\text { outcomes }\end{array}$ \\
\hline & & & & & & $\begin{array}{l}\text { frequency } \rightarrow \text { profit- } \\
\text { per-unit: } n \text {. } s \text {. } \\
* \text { Team learning } \\
\text { orientation } \rightarrow \text { profit- } \\
\text { per-unit: }- \\
\text { Team learning } \\
\text { orientation }^{2} \rightarrow \\
\text { profit-per-unit: - } \\
\text { Team learning } \\
\text { orientation } x \\
\text { performance } \\
\text { performance-to- } \\
\text { plan: - } \\
\text { Team learning } \\
\text { orientation } x \\
\text { performance } \\
\text { profit-per-unit: } \rightarrow\end{array}$ \\
\hline $\begin{array}{l}6 . \\
\text { Carmeli \& } \\
\text { Schaubroeck } \\
\text { (2006) } \\
\text { Leadership } \\
\text { Quarterly }\end{array}$ & $\begin{array}{ll}- & \text { Industry } \\
& \text { conditions (5 } \\
& \text { aspects) } \\
- & \text { Organizational } \\
& \text { age } \\
\text { - } \quad \text { Organizational } \\
\text { size }\end{array}$ & $\begin{array}{l}\text { Task process } \\
\text { Behavioral } \\
\text { integration } \\
\text { (collaborative } \\
\text { behavior, } \\
\text { information } \\
\text { exchange, and joint } \\
\text { decision making) }\end{array}$ & $\begin{array}{l}\text { TMT level } \\
\text { TMT decision } \\
\text { quality (self- } \\
\text { perception) } \\
\text { Organization level } \\
\text { Organizational } \\
\text { decline }\end{array}$ & Questionnaires & $\begin{array}{l}\text { 116 TMTs, via } \\
\text { executive } \\
\text { training } \\
\text { program } \\
\text { (Israel) } \\
\text { TMT identified } \\
\text { by: } \\
\text { Researcher } \\
\text { Average TMT } \\
\text { size: } \\
5.86\end{array}$ & $\begin{array}{l}\text { Analysis: multiple } \\
\text { regression analysis } \\
\text { * TMT behavioral } \\
\text { integration } \rightarrow \\
\text { organizational } \\
\text { decline: - } \\
\text { * TMT behavioral } \\
\text { integration } \rightarrow \\
\text { decision quality: + } \\
\text { Decision quality } \rightarrow \\
\text { organizational } \\
\text { decline: - } \\
\text { NB. Effect of TMT } \\
\text { behavioral } \\
\text { integration still } \\
\text { significant }\end{array}$ \\
\hline
\end{tabular}




\begin{tabular}{|c|c|c|c|c|c|c|}
\hline $\begin{array}{l}\text { Author(s), } \\
\text { year of } \\
\text { publication, \& } \\
\text { journal of the } \\
\text { study }\end{array}$ & $\begin{array}{l}\text { TMT composition } \\
\text { (selection) \& TMT } \\
\text { structure }\end{array}$ & $\begin{array}{l}\text { TMT processes \& } \\
\text { emergent states }\end{array}$ & Outcome measures & Research methods & $\begin{array}{l}\text { Sample, TMT } \\
\text { identification, } \\
\text { \& average } \\
\text { TMT size }\end{array}$ & $\begin{array}{l}\text { Main results for } \\
\text { relationship TMT } \\
\text { processes and } \\
\text { emergent states to } \\
\text { outcomes }\end{array}$ \\
\hline $\begin{array}{l}7 . \\
\text { Chen, Liu, \& } \\
\text { Tjosfold } \\
\text { (2005) } \\
\text { Journal of } \\
\text { Management } \\
\text { Studies }\end{array}$ & n. a. & \begin{tabular}{ll}
\multicolumn{2}{l}{ Task processes } \\
$-\quad$ & Cooperative \\
conflict \\
$-\quad$ & Competitive \\
conflict \\
$-\quad$ Avoiding \\
conflict \\
- $\quad$ Productive \\
conflict
\end{tabular} & $\begin{array}{l}\text { TMT level } \\
\text { Team effectiveness } \\
\text { (CEO rating) } \\
\text { Organization level } \\
\text { Organizational } \\
\text { innovation } \\
\text { (CEO rating) }\end{array}$ & $\begin{array}{l}\text { Questionnaires to } \\
\text { CEO's and vice } \\
\text { presidents via } \\
\text { executive education } \\
\text { program }\end{array}$ & $\begin{array}{l}\text { 105 TMTs } \\
\text { from various } \\
\text { industries } \\
\text { (China) } \\
\text { TMT identified } \\
\text { by: } \\
\text { CEO } \\
\text { Average TMT } \\
\text { size: } \\
\text { "between } 3 \\
\text { and 6" }\end{array}$ & $\begin{array}{l}\text { Analysis: structural } \\
\text { equation analysis } \\
\text { Cooperative conflict } \\
\rightarrow \text { productive } \\
\text { conflict: }+ \\
\text { Competitive conflict } \\
\rightarrow \text { productive } \\
\text { conflict: - } \\
\text { Avoiding conflict } \rightarrow \\
\text { productive conflict: } \\
\text { n. S. } \\
* \text { Productive conflict } \\
\rightarrow \text { TMT } \\
\text { effectiveness: }+ \\
\text { TMT effectiveness } \rightarrow \\
\text { innovation: }+\end{array}$ \\
\hline $\begin{array}{l}8 . \\
\text { Dooley \& } \\
\text { Fryxell, } \\
\text { (1999) } \\
\text { Academy of } \\
\text { Management } \\
\text { Journal }\end{array}$ & $\begin{array}{ll}- & \text { TMT size } \\
\text { - } & \text { Organizational } \\
& \text { slack }\end{array}$ & $\begin{array}{l}\text { Task process } \\
\text { Dissent } \\
\text { Emergent states } \\
-\quad \text { Loyalty } \\
-\quad \text { Competence }\end{array}$ & \begin{tabular}{ll}
\multicolumn{2}{c}{ Decision level } \\
$-\quad$ & Decision \\
- & commitment \\
- & Decision \\
& quality
\end{tabular} & Questionnaires & $\begin{array}{l}86 \text { TMTS of } \\
\text { hospitals } \\
\text { (USA) } \\
\text { TMT identified } \\
\text { by: } \\
\text { CEO }\end{array}$ & $\begin{array}{l}\text { Analysis: multiple } \\
\text { regression analysis } \\
\text { * Dissent } \rightarrow \text { decision } \\
\text { quality: }+ \\
\text { * Dissent } \rightarrow \text { decision } \\
\text { commitment: + }\end{array}$ \\
\hline & & & & & $\begin{array}{l}\text { Average TMT } \\
\text { size: } \\
8.14\end{array}$ & $\begin{array}{l}* \text { Loyalty } \rightarrow \text { decision } \\
\text { quality: } \mathrm{n} \text {. s. } \\
* \text { Loyalty } \rightarrow \text { decision } \\
\text { commitment: } \mathrm{n} \text {. s. } \\
\text { * Competence } \rightarrow \\
\text { decision quality: } \mathrm{n} \text {. s. } \\
* \text { Competence } \rightarrow \\
\text { decision } \\
\text { commitment: }+ \text { (NB. }\end{array}$ \\
\hline
\end{tabular}




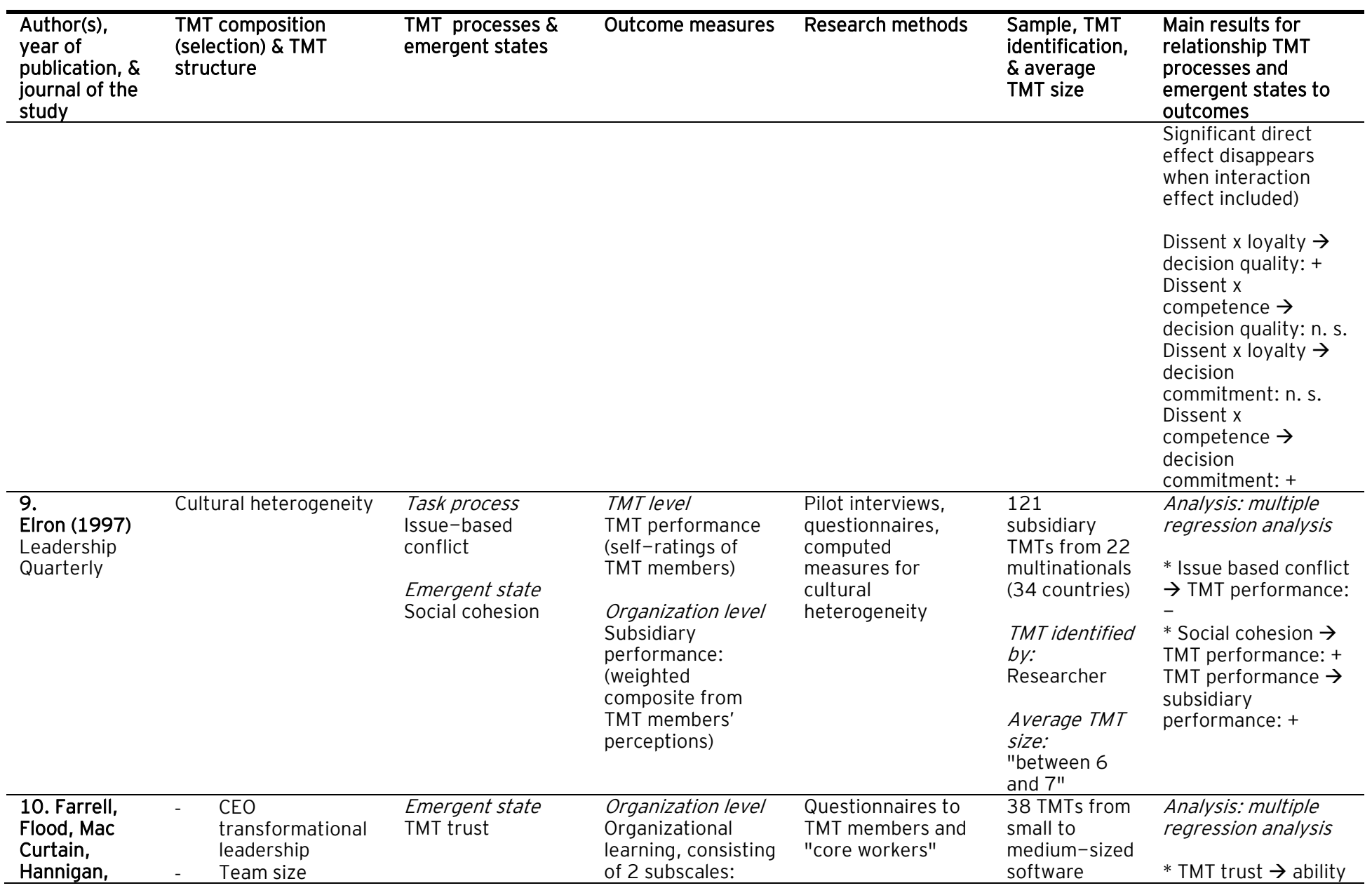




\begin{tabular}{|c|c|c|c|c|c|c|}
\hline $\begin{array}{l}\text { Author(s), } \\
\text { year of } \\
\text { publication, \& } \\
\text { journal of the } \\
\text { study }\end{array}$ & $\begin{array}{l}\text { TMT composition } \\
\text { (selection) \& TMT } \\
\text { structure }\end{array}$ & $\begin{array}{l}\text { TMT processes \& } \\
\text { emergent states }\end{array}$ & Outcome measures & Research methods & $\begin{array}{l}\text { Sample, TMT } \\
\text { identification, } \\
\text { \& average } \\
\text { TMT size }\end{array}$ & $\begin{array}{l}\text { Main results for } \\
\text { relationship TMT } \\
\text { processes and } \\
\text { emergent states to } \\
\text { outcomes }\end{array}$ \\
\hline $\begin{array}{l}\text { Dawson, \& } \\
\text { West (2005) } \\
\text { The Irish } \\
\text { Journal of } \\
\text { Management }\end{array}$ & & & $\begin{array}{ll}- & \text { [Employees'] } \\
\text { Ability to } \\
\text { combine and } \\
\text { exchange } \\
\text { information } \\
\text { - } \quad \text { Employees'] } \\
\text { Motivation to } \\
\text { combine and } \\
\text { exchange } \\
\text { information }\end{array}$ & & $\begin{array}{l}\text { companies } \\
\text { (Ireland) } \\
\text { TMT identified } \\
\text { by: } \\
\text { CEO } \\
\text { Average TMT } \\
\text { size: } \\
\text { not reported }\end{array}$ & $\begin{array}{l}\text { to combine and } \\
\text { exchange } \\
\text { information: + } \\
\text { * TMT trust } \rightarrow \\
\text { motivation to } \\
\text { combine and } \\
\text { exchange } \\
\text { information: } n \text {. s. } \\
\text { CEO } \\
\text { transformational } \\
\text { leadership } \rightarrow \text { TMT } \\
\text { trust: + } \\
\text { CEO } \\
\text { transformational } \\
\text { leadership } \rightarrow \text { ability } \\
\text { to combine and } \\
\text { exchange } \\
\text { information: + } \\
\text { CEO } \\
\text { transformational } \\
\text { leadership } \rightarrow \\
\text { motivation to } \\
\text { combine and } \\
\text { exchange } \\
\text { information: + }\end{array}$ \\
\hline $\begin{array}{l}11 . \\
\text { Flood, } \\
\text { Hannan, } \\
\text { Smith, Turner, } \\
\text { West, \& } \\
\text { Dawson } \\
\text { (2000) } \\
\text { European } \\
\text { Journal of }\end{array}$ & $\begin{array}{l}\text { CEO characteristics: } \\
\text { CEO Leadership style } \\
\text { (authoritarian, } \\
\text { transactional, } \\
\text { transformational, } \\
\text { laissez faire) }\end{array}$ & $\begin{array}{l}\text { Task process } \\
\text { Consensus decision } \\
\text { making } \\
\text { Emergent state } \\
\text { Social integration }\end{array}$ & $\begin{array}{l}\text { TMT level } \\
\text { TMT effectiveness } \\
\text { (self-reported by } \\
\text { TMT members) }\end{array}$ & Questionnaires & $\begin{array}{l}83 \text { TMTs from } \\
\text { high } \\
\text { technology } \\
\text { firms ( } 67 \text { USA } \\
\text { and } 26 \text { Irish) } \\
\text { NB. No } \\
\text { differences in } \\
\text { results }\end{array}$ & $\begin{array}{l}\text { Analysis: multiple } \\
\text { regression analysis } \\
\text { Social integration } \rightarrow \\
\text { consensus decision } \\
\text { making: + } \\
\text { * Social integration } \\
\rightarrow \text { TMT } \\
\text { effectiveness: + }\end{array}$ \\
\hline
\end{tabular}




\begin{tabular}{|c|c|c|c|c|c|c|}
\hline $\begin{array}{l}\text { Author(s), } \\
\text { year of } \\
\text { publication, \& } \\
\text { journal of the } \\
\text { study }\end{array}$ & $\begin{array}{l}\text { TMT composition } \\
\text { (selection) \& TMT } \\
\text { structure }\end{array}$ & $\begin{array}{l}\text { TMT processes \& } \\
\text { emergent states }\end{array}$ & Outcome measures & Research methods & $\begin{array}{l}\text { Sample, TMT } \\
\text { identification, } \\
\text { \& average } \\
\text { TMT size }\end{array}$ & $\begin{array}{l}\text { Main results for } \\
\text { relationship TMT } \\
\text { processes and } \\
\text { emergent states to } \\
\text { outcomes }\end{array}$ \\
\hline $\begin{array}{l}\text { Work and } \\
\text { Organisational } \\
\text { Psychology }\end{array}$ & & & & & $\begin{array}{l}\text { between } \\
\text { samples } \\
\text { TMT identified } \\
\text { by: } \\
\text { CEO }\end{array}$ & $\begin{array}{l}\text { * Consensus decision } \\
\text { making } \rightarrow \text { TMT } \\
\text { effectiveness: + } \\
\text { (NB: Effect social } \\
\text { integration } \\
\text { disappears) }\end{array}$ \\
\hline & & & & & $\begin{array}{l}\text { Average TMT } \\
\text { size: } \\
\text { not reported }\end{array}$ & $\begin{array}{l}\text { Authoritarian } \\
\text { leadership } \rightarrow \text { TMT } \\
\text { effectiveness: } n \text {. s. } \\
\text { (NB. Effect becomes } \\
\text { n. s. after consensus } \\
\text { decision making in } \\
\text { model) } \\
\text { Laissez faire } \\
\text { leadership } \rightarrow \text { TMT } \\
\text { effectiveness: - } \\
\text { Transactional } \\
\text { leadership } \rightarrow \text { TMT } \\
\text { effectiveness: n. s. } \\
\text { Transformational } \\
\text { leadership } \rightarrow \text { TMT } \\
\text { effectiveness: }+ \\
\text { (NB. Effect remains } \\
\text { significant. after } \\
\text { consensus decision } \\
\text { making in model) }\end{array}$ \\
\hline $\begin{array}{l}12 . \\
\text { Hendriks } \\
(2004) \\
\text { PhD thesis }\end{array}$ & $\begin{array}{ll}- & \begin{array}{l}\text { Functional } \\
\text { diversity }\end{array} \\
- & \text { Skill diversity } \\
- & \begin{array}{l}\text { Locus of control } \\
\text { diversity }\end{array} \\
& \\
\text { TMT structure } \\
\text { Centralization of }\end{array}$ & $\begin{array}{l}\text { Task process } \\
\text { Accurate } \\
\text { communication } \\
\text { Emergent states } \\
\text { Cohesion }\end{array}$ & $\begin{array}{l}\text { Organization level } \\
\text { - } \\
\text { Project } \\
\text { problems (as } \\
\text { inverse } \\
\text { indicator for } \\
\text { implementatio } \\
\text { n } \\
\text { effectiveness) }\end{array}$ & $\begin{array}{l}\text { Interviews with CEO } \\
\text { and questionnaires } \\
\text { for TMT }\end{array}$ & $\begin{array}{l}\text { 38 TMTS of IT } \\
\text { service firms } \\
\text { (Netherlands } \\
\text { and Belgium) } \\
\text { TMT identified } \\
\text { by: } \\
\text { CEO }\end{array}$ & $\begin{array}{l}\text { Analysis: multiple } \\
\text { regression analysis } \\
\text { * Accurate } \\
\text { communication } \rightarrow \\
\text { firm profitability: }+ \\
\text { * Cohesion } \rightarrow \text { firm } \\
\text { profitability: } n \text {. s. }\end{array}$ \\
\hline
\end{tabular}




\begin{tabular}{|c|c|c|c|c|c|c|}
\hline $\begin{array}{l}\text { Author(s), } \\
\text { year of } \\
\text { publication, \& } \\
\text { journal of the } \\
\text { study }\end{array}$ & $\begin{array}{l}\text { TMT composition } \\
\text { (selection) \& TMT } \\
\text { structure }\end{array}$ & $\begin{array}{l}\text { TMT processes \& } \\
\text { emergent states }\end{array}$ & Outcome measures & Research methods & $\begin{array}{l}\text { Sample, TMT } \\
\text { identification, } \\
\text { \& average } \\
\text { TMT size }\end{array}$ & $\begin{array}{l}\text { Main results for } \\
\text { relationship TMT } \\
\text { processes and } \\
\text { emergent states to } \\
\text { outcomes }\end{array}$ \\
\hline & decision making & & $\begin{array}{ll}- & \text { Firm } \\
\text { profitability - } \\
\text { (Return on } \\
\text { Sales) }\end{array}$ & & $\begin{array}{l}\text { Average TMT } \\
\text { size: } \\
4.94\end{array}$ & $\begin{array}{l}* \text { Centralization } \rightarrow \\
\text { firm profitability: + } \\
* \text { Accurate } \\
\text { communication } \rightarrow \\
\text { project problems: } \\
\text { n. s. } \\
\text { * Cohesion } \rightarrow \text { project } \\
\text { problems: - } \\
\text { * Centralization } \rightarrow \\
\text { project problems: - }\end{array}$ \\
\hline $\begin{array}{l}13 . \\
\text { laquinto \& } \\
\text { Fredrickson } \\
\text { (1997) } \\
\text { Strategic } \\
\text { Management } \\
\text { Journal }\end{array}$ & $\begin{array}{ll}- & \text { Environmental } \\
& \text { stability } \\
- & \text { Past performance } \\
- & \text { Organizational } \\
& \text { size } \\
\text { - } & \text { TMT size } \\
- & \text { TMT tenure }\end{array}$ & $\begin{array}{l}\text { Emergent state } \\
\text { TMT agreement on } \\
\text { comprehensiveness } \\
\text { of strategic } \\
\text { decision process }\end{array}$ & $\begin{array}{l}\text { Organization level } \\
\text { ROA (5-year } \\
\text { average: following } \\
\text { decision and prior } \\
\text { to decision) }\end{array}$ & $\begin{array}{l}\text { Decision scenario } \\
\text { questionnaire }\end{array}$ & $\begin{array}{l}\text { 95 TMTs from } \\
\text { three different } \\
\text { industries } \\
\text { (use of } \\
\text { samples from } \\
\text { earlier studies } \\
\text { Fredrickson } \\
\text { and } \\
\text { colleagues, } \\
\text { 1984, 1984, } \\
\text { \& 1989) } \\
\text { TMT identified } \\
\text { by: } \\
\text { CEO } \\
\text { Average TMT } \\
\text { size: } \\
4.29\end{array}$ & $\begin{array}{l}\text { Analysis: multiple } \\
\text { regression analysis } \\
\text { * TMT agreement } \rightarrow \\
\text { ROA: }+ \\
\text { Past performance } \rightarrow \\
\text { TMT agreement }:+\end{array}$ \\
\hline $\begin{array}{l}\text { 14. Janssen, } \\
\text { Van de Vliert, } \\
\text { \& Veenstra } \\
\text { (1999) } \\
\text { Journal of }\end{array}$ & $\begin{array}{l}\text { TMT structure } \\
\text { Positive } \\
\text { interdependence }\end{array}$ & \begin{tabular}{ll}
\multicolumn{2}{l}{ Task processes } \\
$-\quad$ & Task conflict \\
- & Integrative \\
conflict \\
behavior
\end{tabular} & \begin{tabular}{ll}
\multicolumn{2}{c}{ Decision level } \\
$-\quad$ & Decision \\
& quality \\
- & Affective \\
& acceptance of
\end{tabular} & Questionnaires & $\begin{array}{l}102 \text { managers } \\
\text { that } \\
\text { functioned in } \\
\text { management } \\
\text { teams }\end{array}$ & $\begin{array}{l}\text { Analysis: multiple } \\
\text { regression analysis } \\
\text { (on individual level) } \\
\text { Positive }\end{array}$ \\
\hline
\end{tabular}

- 29 - 
Chapter 2

\begin{tabular}{|c|c|c|c|c|c|c|}
\hline $\begin{array}{l}\text { Author(s), } \\
\text { year of } \\
\text { publication, \& } \\
\text { journal of the } \\
\text { study }\end{array}$ & $\begin{array}{l}\text { TMT composition } \\
\text { (selection) \& TMT } \\
\text { structure }\end{array}$ & $\begin{array}{l}\text { TMT processes \& } \\
\text { emergent states }\end{array}$ & Outcome measures & Research methods & $\begin{array}{l}\text { Sample, TMT } \\
\text { identification, } \\
\text { \& average } \\
\text { TMT size }\end{array}$ & $\begin{array}{l}\text { Main results for } \\
\text { relationship TMT } \\
\text { processes and } \\
\text { emergent states to } \\
\text { outcomes }\end{array}$ \\
\hline Management & & $\begin{array}{l}\text { - } \begin{array}{l}\text { Distributive } \\
\text { conflict } \\
\text { behavior }\end{array} \\
\text { Relationship } \\
\text { process } \\
\text { Person conflict }\end{array}$ & decisions & & $\begin{array}{l}\text { (Netherlands) } \\
\text { TMT identified } \\
\text { by: } \\
\text { Respondents } \\
\text { Average TMT } \\
\text { size: } \\
7\end{array}$ & $\begin{array}{l}\text { interdependence } \rightarrow \\
\text { integrative behavior: } \\
+ \\
\text { Task conflict } \rightarrow \\
\text { integrative behavior: } \\
\text { n. s. } \\
\text { Person conflict } \rightarrow \\
\text { integrative behavior: } \\
- \\
\text { Positive } \\
\text { interdependence } \rightarrow \\
\text { distributive behavior: } \\
+ \\
\text { Task conflict } \rightarrow \\
\text { distributive behavior: } \\
\text { n. s. } \\
\text { Person conflict } \rightarrow \\
\text { distributive behavior: } \\
+ \\
\text { Positive } \\
\text { interdependence } \rightarrow \\
\text { decision quality: }+ \\
\text { Task conflict } \rightarrow \\
\text { decision quality: n. s. } \\
\text { Person conflict } \rightarrow \\
\text { decision quality: }- \\
\text { Positive } \\
\text { interdependence } \rightarrow \\
\text { affective } \\
\text { acceptance: }+ \\
\text { Task conflict } \rightarrow \\
\text { affective }\end{array}$ \\
\hline
\end{tabular}




\begin{tabular}{|c|c|c|c|c|c|c|}
\hline $\begin{array}{l}\text { Author(s), } \\
\text { year of } \\
\text { publication, \& } \\
\text { journal of the } \\
\text { study }\end{array}$ & $\begin{array}{l}\text { TMT composition } \\
\text { (selection) \& TMT } \\
\text { structure }\end{array}$ & $\begin{array}{l}\text { TMT processes \& } \\
\text { emergent states }\end{array}$ & Outcome measures & Research methods & $\begin{array}{l}\text { Sample, TMT } \\
\text { identification, } \\
\text { \& average } \\
\text { TMT size }\end{array}$ & $\begin{array}{l}\text { Main results for } \\
\text { relationship TMT } \\
\text { processes and } \\
\text { emergent states to } \\
\text { outcomes }\end{array}$ \\
\hline & & & & & & $\begin{array}{l}\text { acceptance: n. s. } \\
\text { Person conflict } \rightarrow \\
\text { affective } \\
\text { acceptance: - } \\
\text { NB. For all } \\
\text { dependent variables: } \\
\text { 3-way interaction } \\
\text { effects of PI x TC x } \\
\text { PC; effect is negative } \\
\text { for distributive } \\
\text { behavior and positive } \\
\text { for all other } \\
\text { variables. All 2-way } \\
\text { interaction effects: } \\
\text { n. s. }\end{array}$ \\
\hline $\begin{array}{l}15 . \\
\text { Knight, } \\
\text { Pearce, } \\
\text { Smith, Olian, } \\
\text { Sims, Smith, \& } \\
\text { Flood. (1999) } \\
\text { Strategic } \\
\text { Management } \\
\text { Journal }\end{array}$ & $\begin{array}{ll}- & \text { Location (USA or } \\
& \text { Ireland) } \\
- & \text { Functional } \\
& \text { diversity } \\
- & \text { Age diversity } \\
- & \text { Educational } \\
& \text { diversity } \\
- & \text { Employment } \\
& \text { tenure diversity }\end{array}$ & $\begin{array}{l}\text { Task process } \\
\text { Agreement seeking } \\
\text { Relationship } \\
\text { process } \\
\text { Interpersonal } \\
\text { conflict } \\
\text { Emergent state } \\
\text { Strategic } \\
\text { consensus } \\
\text { (measured as } \\
\text { similarity in mental } \\
\text { models in TMT } \\
\text { members' } \\
\text { interpretations of } \\
\text { firms' strategic } \\
\text { orientation) }\end{array}$ & 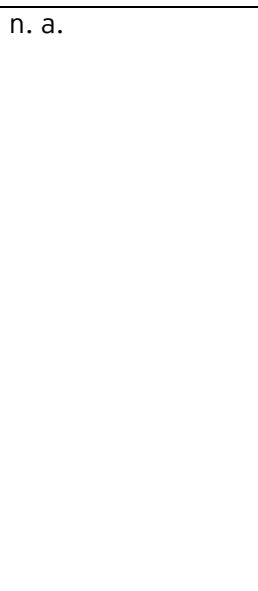 & $\begin{array}{l}\text { Interviews with } \\
\text { CEO's } \\
\text { Questionnaires for } \\
\text { TMT on } \\
\text { demographic, } \\
\text { process-oriented } \\
\text { issues and } \\
\text { questions testing } \\
\text { mental models }\end{array}$ & $\begin{array}{l}2 \text { samples } \\
53 \text { TMTs from } \\
\text { high- } \\
\text { technology } \\
\text { firms (USA) } \\
26 \text { TMTs from } \\
\text { subsidiaries of } \\
\text { USA multi- } \\
\text { nationals } \\
\text { (Ireland) } \\
\text { TMT identified } \\
\text { by: } \\
\text { CEO } \\
\text { Average TMT } \\
\text { size: } \\
\text { not reported }\end{array}$ & $\begin{array}{l}\text { Analysis: structural } \\
\text { equation modeling } \\
\text { Interpersonal conflict } \\
\rightarrow \text { agreement } \\
\text { seeking: - } \\
\text { Agreement seeking } \\
\rightarrow \text { strategic } \\
\text { consensus: + }\end{array}$ \\
\hline
\end{tabular}


Chapter 2

\begin{tabular}{|c|c|c|c|c|c|c|}
\hline $\begin{array}{l}\text { Author(s), } \\
\text { year of } \\
\text { publication, \& } \\
\text { journal of the } \\
\text { study }\end{array}$ & $\begin{array}{l}\text { TMT composition } \\
\text { (selection) \& TMT } \\
\text { structure }\end{array}$ & $\begin{array}{l}\text { TMT processes \& } \\
\text { emergent states }\end{array}$ & Outcome measures & Research methods & $\begin{array}{l}\text { Sample, TMT } \\
\text { identification, } \\
\text { \& average } \\
\text { TMT size }\end{array}$ & $\begin{array}{l}\text { Main results for } \\
\text { relationship TMT } \\
\text { processes and } \\
\text { emergent states to } \\
\text { outcomes }\end{array}$ \\
\hline $\begin{array}{l}\text { 16. Lubatkin, } \\
\text { Simsek, Ling, } \\
\text { \& Veiga } \\
\text { (2006) } \\
\text { Journal of } \\
\text { Management }\end{array}$ & $\begin{array}{ll}- & \text { TMT size } \\
- & \text { TMT tenure }\end{array}$ & $\begin{array}{l}\text { Task process } \\
\text { Behavioral } \\
\text { integration (during } \\
\text { past } 3 \text { years) }\end{array}$ & $\begin{array}{l}\text { Organization level } \\
\text { - } \quad \text { Firm } \\
\text { ambidextrous } \\
\text { orientation } \\
\text { - } \quad \text { Firm } \\
\text { performance } \\
\text { (with 1-year } \\
\text { time-lag) }\end{array}$ & Questionnaires & $\begin{array}{l}139 \text { TMTs } \\
\text { from small- to } \\
\text { medium-sized } \\
\text { firms from } \\
\text { various } \\
\text { industries in } \\
\text { New England } \\
\text { (USA) } \\
\text { TMT identified } \\
\text { by: } \\
\text { CEO } \\
\text { Average TMT } \\
\text { size: } \\
4.4\end{array}$ & $\begin{array}{l}\text { Analysis: structural } \\
\text { equation modeling } \\
\text { * TMT behavioral } \\
\text { integration } \rightarrow \text { firm } \\
\text { ambidextrous } \\
\text { orientation: + } \\
\text { Firm ambidextrous } \\
\text { orientation } \rightarrow \text { firm } \\
\text { performance: + } \\
\text { NB. Model that } \\
\text { included additional } \\
\text { direct link between } \\
\text { TMT behavioral } \\
\text { integration and firm } \\
\text { performance had } \\
\text { poorer fit }\end{array}$ \\
\hline $\begin{array}{l}\text { 17. Olson, } \\
\text { Parayitam, \& } \\
\text { Bao (2007) } \\
\text { Journal of } \\
\text { Management }\end{array}$ & $\begin{array}{ll}- & \text { Cognitive } \\
& \text { diversity } \\
\text { - } & \text { TMT size } \\
\text { - } & \text { TMT tenure }\end{array}$ & $\begin{array}{l}\text { Task process } \\
\text { Task conflict } \\
\text { Relationship } \\
\text { process } \\
\text { Relationship } \\
\text { conflict } \\
\text { Emergent state } \\
\text { Competence- } \\
\text { based trust }\end{array}$ & \begin{tabular}{ll}
\multicolumn{2}{c}{ Decision level } \\
$-\quad$ Decision \\
- $\quad$ understanding \\
Decision \\
commitment \\
- $\quad$ Decision \\
quality
\end{tabular} & Questionnaires & $\begin{array}{l}85 \text { TMTS of } \\
\text { hospitals } \\
\text { (USA) } \\
\text { TMT identified } \\
\text { by: } \\
\text { CEO } \\
\text { Average TMT } \\
\text { size: } \\
4.8\end{array}$ & $\begin{array}{l}\text { Analysis: multiple } \\
\text { regression analysis } \\
\text { and structural } \\
\text { equation modeling } \\
\\
\text { Relationship conflict } \\
\rightarrow \text { task conflict: }+ \\
\text { Cognitive diversity } \rightarrow \\
\text { task conflict: }+ \\
\text { Competence-based } \\
\text { trust } \rightarrow \text { task conflict: } \\
+ \\
\text { Cognitive diversity x } \\
\text { competence-based } \\
\text { trust } \rightarrow \text { task conflict: } \\
+\end{array}$ \\
\hline
\end{tabular}




\begin{tabular}{|c|c|c|c|c|c|c|}
\hline $\begin{array}{l}\text { Author(s), } \\
\text { year of } \\
\text { publication, \& } \\
\text { journal of the } \\
\text { study }\end{array}$ & $\begin{array}{l}\text { TMT composition } \\
\text { (selection) \& TMT } \\
\text { structure }\end{array}$ & $\begin{array}{l}\text { TMT processes \& } \\
\text { emergent states }\end{array}$ & Outcome measures & Research methods & $\begin{array}{l}\text { Sample, TMT } \\
\text { identification, } \\
\text { \& average } \\
\text { TMT size }\end{array}$ & $\begin{array}{l}\text { Main results for } \\
\text { relationship TMT } \\
\text { processes and } \\
\text { emergent states to } \\
\text { outcomes } \\
\text { * Task conflict } \rightarrow \\
\text { decision } \\
\text { understanding: + } \\
\text { * Task conflict } \rightarrow \\
\text { decision } \\
\text { commitment: }+ \\
\text { * Task conflict } \rightarrow \\
\text { decision quality: }+\end{array}$ \\
\hline $\begin{array}{l}18 . \\
\text { Peterson, } \\
\text { Owens, } \\
\text { Tetlock, Fan, } \\
\text { \& Martorana } \\
\text { (1998) } \\
\text { Organizational } \\
\text { Behavior and } \\
\text { Human } \\
\text { Decision } \\
\text { Processes }\end{array}$ & n. a. & $\begin{array}{l}\text { Emergent states } \\
\text { 1. Rigidity - } \\
\text { flexibility } \\
\text { 2. Control - crisis } \\
\text { 3. Optimism - } \\
\text { pessimism } \\
\text { 4. Leader } \\
\text { weakness - } \\
\text { strength } \\
\text { 5. Factionalism - } \\
\text { cohesiveness } \\
\text { 6. Legalism - } \\
\text { corruption } \\
\text { 7. Decentralization } \\
\text { - centralization } \\
\text { 8. Risk averse - } \\
\text { risk taking }\end{array}$ & $\begin{array}{l}\text { Organization level } \\
\text { Successful and } \\
\text { unsuccessful TMTs } \\
\text { pre-defined }\end{array}$ & $\begin{array}{l}\text { Analysis of } \\
\text { historical case } \\
\text { studies (texts) by } \\
\text { using Corporate } \\
\text { Group Dynamics Q- } \\
\text { sort (GDQ) }\end{array}$ & $\begin{array}{l}7 \text { TMTs from } \\
\text { large business } \\
\text { organizations } \\
\text { in successful } \\
\text { and } \\
\text { unsuccessful } \\
\text { period } \\
\text { (USA) } \\
\text { TMT identified } \\
\text { by: } \\
\text { Researchers } \\
\text { Average TMT } \\
\text { size: } \\
\text { not reported }\end{array}$ & $\begin{array}{l}\text { Analysis: } \\
\text { correlations } \\
\text { Successful TMTs } \\
\text { showed: } \\
\text { - more } \\
\text { intellectual } \\
\text { ability } \\
\text { less } \\
\text { consciousness } \\
\text { of crisis } \\
\text { less pessimism } \\
\text { (more optimism) } \\
\text { greater leader } \\
\text { strength } \\
\text { more } \\
\text { cohesiveness } \\
\text { less corruption } \\
\text { less } \\
\text { centralization } \\
\text { more risk- } \\
\text { taking }\end{array}$ \\
\hline $\begin{array}{l}19 . \\
\text { Peterson, } \\
\text { Smith, } \\
\text { Martorana, \& } \\
\text { Owens (2003) }\end{array}$ & 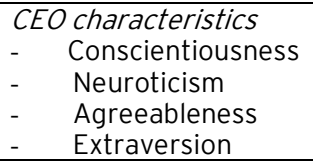 & $\begin{array}{l}\text { Emergent states } \\
\text { 1. Rigidity - } \\
\text { flexibility } \\
\text { 2. Control - crisis } \\
\text { 3. Optimism - }\end{array}$ & $\begin{array}{l}\text { Organization level } \\
\text { Income growth } \\
\text { (corrected for } \\
\text { attenuation) }\end{array}$ & $\begin{array}{l}\text { Studies of archival } \\
\text { material (written } \\
\text { reports) } \\
\text { Personality data } \\
\text { from archival }\end{array}$ & $\begin{array}{l}17 \text { CEO's of } \\
\text { different, } \\
\text { large } \\
\text { organizations } \\
\text { from the past }\end{array}$ & $\begin{array}{l}\text { Analysis: } \\
\text { correlations } \\
\text { Flexibility } \rightarrow \text { income } \\
\text { growth: }+\end{array}$ \\
\hline
\end{tabular}


Chapter 2

\begin{tabular}{|c|c|c|c|c|c|c|}
\hline $\begin{array}{l}\text { Author(s), } \\
\text { year of } \\
\text { publication, \& } \\
\text { journal of the } \\
\text { study }\end{array}$ & $\begin{array}{l}\text { TMT composition } \\
\text { (selection) \& TMT } \\
\text { structure }\end{array}$ & $\begin{array}{l}\text { TMT processes \& } \\
\text { emergent states }\end{array}$ & Outcome measures & Research methods & $\begin{array}{l}\text { Sample, TMT } \\
\text { identification, } \\
\text { \& average } \\
\text { TMT size }\end{array}$ & $\begin{array}{l}\text { Main results for } \\
\text { relationship TMT } \\
\text { processes and } \\
\text { emergent states to } \\
\text { outcomes }\end{array}$ \\
\hline $\begin{array}{l}\text { Journal of } \\
\text { Applied } \\
\text { Psychology }\end{array}$ & - $\quad$ Openness & $\begin{array}{l}\text { pessimism } \\
\text { 4. Leader } \\
\text { weakness - } \\
\text { dominance } \\
\text { 5. Factionalism - } \\
\text { cohesiveness } \\
\text { 6. Legalism - } \\
\text { corruption } \\
\text { 7. Decentralization } \\
\text { - centralization } \\
\text { 8. Risk averse - } \\
\text { risk taking }\end{array}$ & & $\begin{array}{l}\text { Sources, for } \\
\text { classifying: } \\
\text { California Adult Q- } \\
\text { Set } \\
\text { TMT group } \\
\text { dynamics, for } \\
\text { classifying: Group } \\
\text { Dynamics Q-sort }\end{array}$ & $\begin{array}{l}25 \text { years } \\
\text { (USA) } \\
\text { TMT identified } \\
\text { by: } \\
\text { Researchers } \\
\text { Average TMT } \\
\text { size: } \\
\text { not reported }\end{array}$ & $\begin{array}{l}\text { Crisis } \rightarrow \text { income } \\
\text { growth: } \mathrm{n} \text {. s. } \\
\text { Pessimism } \rightarrow \text { income } \\
\text { growth: }- \\
\text { Leader dominance } \rightarrow \\
\text { income growth: } \mathrm{n} \text {. s. } \\
\text { Cohesiveness } \rightarrow \\
\text { income growth: + } \\
\text { Corruption } \rightarrow \text { income } \\
\text { growth: } \mathrm{n} \text {. s. } \\
\text { Centralization } \rightarrow \\
\text { income growth: } \mathrm{n} \text {. s. } \\
\text { Risk taking } \rightarrow \\
\text { income growth: }+\end{array}$ \\
\hline $\begin{array}{l}20 . \\
\text { Pitcher \& } \\
\text { Smith (2001) } \\
\text { Organization } \\
\text { Science }\end{array}$ & $\begin{array}{ll}- & \text { Industry } \\
& \text { experience } \\
- & \text { TMT tenure } \\
- & \text { Functional } \\
\text { diversity } \\
-\quad \text { Personality } \\
\text { diversity } \\
\\
\text { TMT structure } \\
\text { Power distribution }\end{array}$ & $\begin{array}{ll}\text { Task processes } \\
\text { - } \quad \text { Formal vs. } \\
\text { informal } \\
\text { decision } \\
\text { making } \\
\text { process } \\
\text { Centralized } \\
\text { vs. } \\
\text { decentralized } \\
\text { decision } \\
\text { making } \\
\text { process }\end{array}$ & \begin{tabular}{ll}
\multicolumn{2}{c}{ Organization level } \\
- & Diversification \\
- & Innovation \\
- & Asset growth \\
- & Market/book \\
& value
\end{tabular} & $\begin{array}{l}\text { Observation, } \\
\text { archival data, } \\
\text { informal meetings } \\
\text { and } 50 \text { interviews } \\
\text { with TMT members }\end{array}$ & $\begin{array}{l}\text { TMT from } \\
\text { financial } \\
\text { services firm } \\
\text { over an eight } \\
\text { year period in } \\
\text { which TMT } \\
\text { composition } \\
\text { changed } \\
\text { (USA) } \\
\text { TMT identified } \\
\text { by: } \\
\text { CEO } \\
\text { Average TMT } \\
\text { size: } \\
8\end{array}$ & $\begin{array}{l}\text { Analysis: qualitative } \\
\text { analyses } \\
\text { Informal and } \\
\text { decentralized } \\
\text { decision making } \\
\text { processes were } \\
\text { associated with high } \\
\text { diversification and } \\
\text { good TMT } \\
\text { performance. } \\
\text { Increased formalized } \\
\text { and centralized } \\
\text { decision making } \\
\text { processes were } \\
\text { associated with a } \\
\text { moderate degree of } \\
\text { diversification, as } \\
\text { well as reaching an } \\
\text { assets plateau. }\end{array}$ \\
\hline
\end{tabular}




\begin{tabular}{|c|c|c|c|c|c|c|}
\hline $\begin{array}{l}\text { Author(s), } \\
\text { year of } \\
\text { publication, \& } \\
\text { journal of the } \\
\text { study }\end{array}$ & $\begin{array}{l}\text { TMT composition } \\
\text { (selection) \& TMT } \\
\text { structure }\end{array}$ & $\begin{array}{l}\text { TMT processes \& } \\
\text { emergent states }\end{array}$ & Outcome measures & Research methods & $\begin{array}{l}\text { Sample, TMT } \\
\text { identification, } \\
\text { \& average } \\
\text { TMT size }\end{array}$ & $\begin{array}{l}\text { Main results for } \\
\text { relationship TMT } \\
\text { processes and } \\
\text { emergent states to } \\
\text { outcomes }\end{array}$ \\
\hline & & & & & & $\begin{array}{l}\text { Complete formalized } \\
\text { and centralized } \\
\text { decision making } \\
\text { processes were } \\
\text { associated with low } \\
\text { diversification, low } \\
\text { innovation, and } \\
\text { decreased market- } \\
\text { book values. }\end{array}$ \\
\hline $\begin{array}{l}21 . \\
\text { Rau (2005) } \\
\text { Small Group } \\
\text { Research }\end{array}$ & $\begin{array}{ll}\text { - } & \text { Organizational } \\
\text { size } \\
\text { - } \quad \text { Organizational } \\
\text { strategy } \\
\text { - } \quad \text { Expertise } \\
\text { composition }\end{array}$ & $\begin{array}{l}\text { Relationship } \\
\text { process } \\
\text { Relationship } \\
\text { conflict } \\
\text { Emergent states } \\
\text { - } \quad \text { Trust } \\
-\quad \text { Expertise } \\
\quad \text { location (as } \\
\quad \text { dimension of } \\
\text { TMT } \\
\text { transactive } \\
\text { memory) }\end{array}$ & $\begin{array}{l}\text { Organization level } \\
\text { Return on average } \\
\text { assets at the end of } \\
\text { the year }\end{array}$ & Questionnaires & $\begin{array}{l}\text { 111 TMTs } \\
\text { from banks in } \\
\text { Minnesota } \\
\text { (USA) } \\
\text { TMT identified } \\
\text { by: } \\
\text { CEO } \\
\text { Average TMT } \\
\text { size: } \\
5.05\end{array}$ & $\begin{array}{l}\text { Analysis: multiple } \\
\text { regression analysis } \\
\text { * Relationship } \\
\text { conflict } \rightarrow \\
\text { performance: - } \\
\text { * Trust } \rightarrow \\
\text { performance: } n . \text { s. } \\
\text { ("marginally } \\
\text { significant") } \\
\text { * Expertise } \\
\text { location } \rightarrow \\
\text { performance: + }\end{array}$ \\
\hline & & $\begin{array}{l}\text { As controls: } \\
\text { Control resolution } \\
\text { (4 techniques: } \\
\text { ignoring or } \\
\text { avoiding issues, } \\
\text { smoothing over } \\
\text { issues, openly } \\
\text { confronting issues, } \\
\text { resorting to } \\
\text { authority) }\end{array}$ & & & & $\begin{array}{l}\text { Conflict resolution } \rightarrow \\
\text { performance: } n \text {. s. } \\
\text { Expertise location x } \\
\text { relationship conflict } \\
\rightarrow \text { performance: } n \text {. s. } \\
\text { ("marginally } \\
\text { significant") } \\
\text { Expertise location x } \\
\text { trust } \rightarrow \\
\text { performance: n. s. }\end{array}$ \\
\hline
\end{tabular}




\begin{tabular}{|c|c|c|c|c|c|c|}
\hline $\begin{array}{l}\text { Author(s), } \\
\text { year of } \\
\text { publication, \& } \\
\text { journal of the } \\
\text { study }\end{array}$ & $\begin{array}{l}\text { TMT composition } \\
\text { (selection) \& TMT } \\
\text { structure }\end{array}$ & $\begin{array}{l}\text { TMT processes \& } \\
\text { emergent states }\end{array}$ & Outcome measures & Research methods & $\begin{array}{l}\text { Sample, TMT } \\
\text { identification, } \\
\text { \& average } \\
\text { TMT size }\end{array}$ & $\begin{array}{l}\text { Main results for } \\
\text { relationship TMT } \\
\text { processes and } \\
\text { emergent states to } \\
\text { outcomes }\end{array}$ \\
\hline $\begin{array}{l}22 . \\
\text { Simons, } \\
\text { Pelled, \& } \\
\text { Smith (1999) } \\
\text { Academy of } \\
\text { Management } \\
\text { Journal }\end{array}$ & $\begin{array}{ll}- & \text { TMT tenure } \\
- & \text { Educational level } \\
- & \text { Functional } \\
& \text { background } \\
- & \text { TMT size } \\
- & \text { Perceived } \\
& \text { environmental } \\
& \text { uncertainty (PEU) } \\
\text { diversity }\end{array}$ & $\begin{array}{l}\text { Task process } \\
\text { Team debate }\end{array}$ & $\begin{array}{l}\text { Decision level } \\
\text { Decision } \\
\text { comprehensiveness } \\
\text { Organization level } \\
\text { - Change in } \\
\quad \text { profitability } \\
\text { - Change in } \\
\quad \text { sales }\end{array}$ & $\begin{array}{l}\text { Questionnaires } \\
\text { (about one specific } \\
\text { decision) }\end{array}$ & $\begin{array}{l}\mathrm{N}=57 \text { TMTs } \\
\text { of high } \\
\text { technology } \\
\text { firms } \\
\text { (USA) } \\
\text { TMT identified } \\
\text { by: } \\
\text { CEO } \\
\text { Average TMT } \\
\text { size: } \\
6.06\end{array}$ & $\begin{array}{l}\text { Analysis: multiple } \\
\text { regression analysis } \\
\text { * Debate } \rightarrow \\
\text { comprehensiveness: } \\
+ \\
\text { * Debate } \rightarrow \text { change } \\
\text { in profitability: } n \text {. } s \text {. } \\
\text { * Debate } \rightarrow \text { change } \\
\text { in sales: } n \text {. s. } \\
\text { Debate x PEU } \\
\text { diversity } \rightarrow \text { change } \\
\text { in profitability: }+ \\
\text { Debate } x \text { PEU } \\
\text { diversity } \rightarrow \text { change } \\
\text { in sales: }+ \\
\text { After interaction } \\
\text { effects } \\
\text { comprehensiveness } \\
\text { has mediating effect } \\
\text { on both change in } \\
\text { sales and } \\
\text { profitability }\end{array}$ \\
\hline $\begin{array}{l}23 . \\
\text { Simons \& } \\
\text { Peterson } \\
\text { (2000) } \\
\text { Journal of } \\
\text { Applied } \\
\text { Psychology }\end{array}$ & n. a. & $\begin{array}{l}\text { Task processes } \\
\text { - } \quad \text { Control tactics } \\
\text { - } \quad \text { Task conflict } \\
\text { Relationship } \\
\text { process } \\
\text { Relationship } \\
\text { conflict } \\
\text { Emergent state }\end{array}$ & n. a. & Questionnaires & $\begin{array}{l}70 \text { TMTS of } \\
\text { hotel } \\
\text { companies } \\
\text { (USA) } \\
\text { TMT identified } \\
\text { by: } \\
\text { CEO }\end{array}$ & $\begin{array}{l}\text { Analysis: multiple } \\
\text { regression analysis } \\
\text { Task conflict } \rightarrow \\
\text { relationship conflict: } \\
+ \\
\text { Intra-team trust } \rightarrow \\
\text { relationship conflict: } \\
- \\
\text { Control tactics } \rightarrow\end{array}$ \\
\hline
\end{tabular}




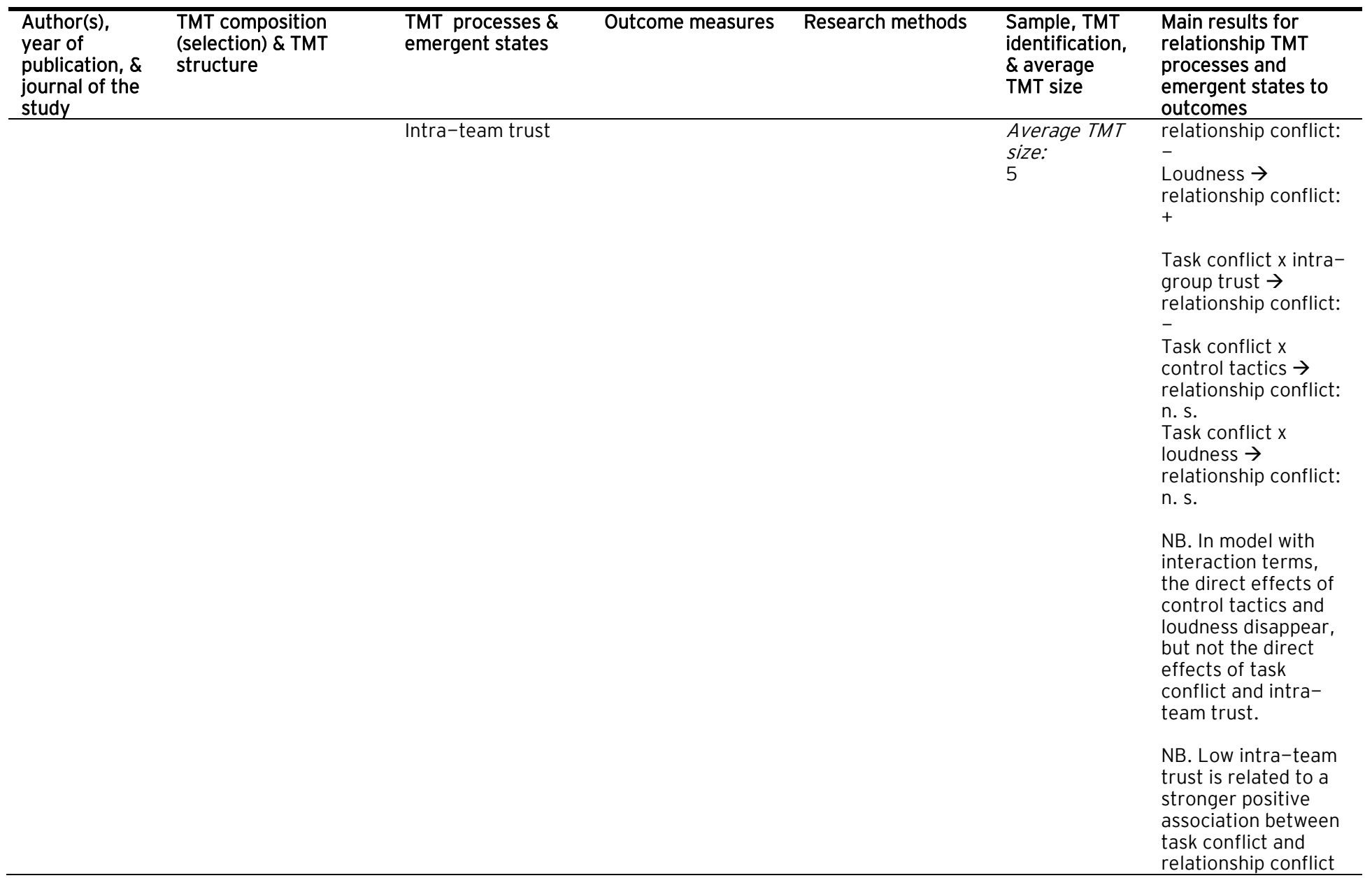




\begin{tabular}{|c|c|c|c|c|c|c|}
\hline $\begin{array}{l}\text { Author(s), } \\
\text { year of } \\
\text { publication, \& } \\
\text { journal of the } \\
\text { study }\end{array}$ & $\begin{array}{l}\text { TMT composition } \\
\text { (selection) \& TMT } \\
\text { structure }\end{array}$ & $\begin{array}{l}\text { TMT processes \& } \\
\text { emergent states }\end{array}$ & Outcome measures & Research methods & $\begin{array}{l}\text { Sample, TMT } \\
\text { identification, } \\
\& \text { average } \\
\text { TMT size }\end{array}$ & $\begin{array}{l}\text { Main results for } \\
\text { relationship TMT } \\
\text { processes and } \\
\text { emergent states to } \\
\text { outcomes }\end{array}$ \\
\hline $\begin{array}{l}24 . \\
\text { Simsek, } \\
\text { Veiga, } \\
\text { Lubatkin, \& } \\
\text { Dino (2005) } \\
\text { Academy of } \\
\text { Management } \\
\text { Journal }\end{array}$ & $\begin{array}{ll}- & \text { CEO collectivistic } \\
& \text { orientation } \\
\text { - } & \text { CEO tenure } \\
\text { - } & \text { TMT demographic } \\
& \text { diversity in terms } \\
& \text { of TMT tenure, } \\
\text { education level, \& } & \text { functional } \\
\text { background } & \text { TMT goal } \\
\text { - } & \text { preference } \\
\text { diversity } \\
\text { - TMT tenure } \\
\text { - TMT size }\end{array}$ & $\begin{array}{l}\text { Task process } \\
\text { Behavioral } \\
\text { integration } \\
\text { NB. Emergent state } \\
\text { studied as outcome }\end{array}$ & $\begin{array}{l}\text { Organization level } \\
\text { Firm performance } \\
\text { (measured as } \\
\text { control for } \\
\text { behavioral } \\
\text { integration) }\end{array}$ & $\begin{array}{l}\text { Questionnaires } \\
\text { CEO's reported } \\
\text { characteristics of } \\
\text { their TMT }\end{array}$ & $\begin{array}{l}402 \text { CEO's of } \\
\text { small and } \\
\text { medium-sized } \\
\text { firms } \\
\text { (USA) } \\
\text { TMT identified } \\
\text { by: } \\
\text { CEO } \\
\text { Average TMT } \\
\text { size: } \\
4.75\end{array}$ & $\begin{array}{l}\text { Analysis: structural } \\
\text { equation modeling } \\
\text { TMT goal preference } \\
\text { diversity } \rightarrow \\
\text { behavioral } \\
\text { integration: - } \\
\text { Firm size } \rightarrow \\
\text { behavioral } \\
\text { integration: - } \\
\text { Firm performance } \rightarrow \\
\text { behavioral } \\
\text { integration: + } \\
\mathrm{R}^{2} \text { was highest for } \\
\text { model with } \\
\text { determinants from } \\
\text { CEO, TMT, and firm } \\
\text { level } \rightarrow \text { "TMT } \\
\text { behavioral } \\
\text { integration is multi- } \\
\text { level in origin" }\end{array}$ \\
\hline $\begin{array}{l}25 . \\
\text { Smith, Smith, } \\
\text { Olian, Sims, O' } \\
\text { Bannon \& } \\
\text { Scully (1994) } \\
\text { Administrative } \\
\text { Science } \\
\text { Quarterly }\end{array}$ & $\begin{array}{ll}- & \text { TMT size } \\
- & \text { TMT tenure } \\
- & \text { TMT } \\
& \text { heterogeneity }\end{array}$ & $\begin{array}{l}\text { Task process } \\
\text { Communication } \\
\text { frequency } \\
\text { Relationship } \\
\text { process } \\
\text { Informal } \\
\text { communication }\end{array}$ & \begin{tabular}{ll}
\multicolumn{2}{c}{ Organization level } \\
$-\quad$ ROI \\
$-\quad$ One-year \\
$\quad$ sales growth
\end{tabular} & $\begin{array}{l}\text { Interviews with } \\
\text { CEOs and } \\
\text { questionnaires } \\
\text { Model testing for } \\
\text { influence } \\
\text { demographics and } \\
\text { process variables }\end{array}$ & $\begin{array}{l}53 \text { TMTS of } \\
\text { high- } \\
\text { technology } \\
\text { firms (USA) } \\
\text { TMT identified } \\
\text { by: } \\
\text { CEO }\end{array}$ & $\begin{array}{l}\text { Analysis: multiple } \\
\text { regression and path } \\
\text { analysis } \\
\text { Little support for } \\
\text { demography model. } \\
\text { Partial support for } \\
\text { intervening model. }\end{array}$ \\
\hline & & $\begin{array}{l}\text { Emergent state } \\
\text { Social integration }\end{array}$ & & & $\begin{array}{l}\text { Average TMT } \\
\text { size: } \\
5.2\end{array}$ & $\begin{array}{l}* \text { Communication } \\
\text { frequency } \rightarrow \mathrm{ROI}:- \\
* \text { Communication }\end{array}$ \\
\hline
\end{tabular}




\begin{tabular}{|c|c|c|c|c|c|c|}
\hline $\begin{array}{l}\text { Author(s), } \\
\text { year of } \\
\text { publication, \& } \\
\text { journal of the } \\
\text { study }\end{array}$ & $\begin{array}{l}\text { TMT composition } \\
\text { (selection) \& TMT } \\
\text { structure }\end{array}$ & $\begin{array}{l}\text { TMT processes \& } \\
\text { emergent states }\end{array}$ & Outcome measures & Research methods & $\begin{array}{l}\text { Sample, TMT } \\
\text { identification, } \\
\text { \& average } \\
\text { TMT size }\end{array}$ & $\begin{array}{l}\text { Main results for } \\
\text { relationship TMT } \\
\text { processes and } \\
\text { emergent states to } \\
\text { outcomes }\end{array}$ \\
\hline & & & & & & $\begin{array}{l}\text { frequency } \rightarrow \text { Sales } \\
\text { growth: }- \\
\text { * Informal } \\
\text { communication } \rightarrow \\
\text { ROI: n. s. } \\
\text { * Informal } \\
\text { communication } \rightarrow \\
\text { Sales growth: - } \\
\text { * Social integration } \\
\rightarrow \text { ROI: + } \\
* \text { Social integration } \\
\rightarrow \text { Sales growth: }+ \\
\end{array}$ \\
\hline $\begin{array}{l}26 . \\
\text { Srivastava, } \\
\text { Bartol, \& } \\
\text { Locke (2006) } \\
\text { Academy of } \\
\text { Management } \\
\text { Journal }\end{array}$ & 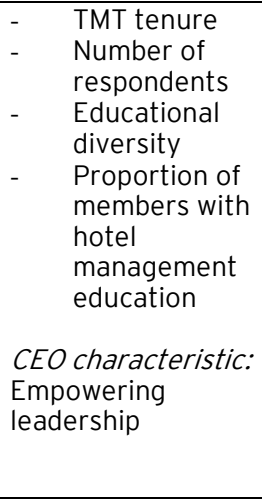 & $\begin{array}{l}\text { Task process } \\
\text { Knowledge sharing } \\
\text { Emergent state } \\
\text { TMT efficacy }\end{array}$ & $\begin{array}{l}\text { Organization level } \\
\text { Hotel property } \\
\text { performance: } \\
\text { relative room rate } \\
\text { realization as } \\
\text { compared to local } \\
\text { competitors } \\
\text { NB. The authors } \\
\text { have named this } \\
\text { 'team performance' }\end{array}$ & Questionnaires & $\begin{array}{l}102 \text { TMTs } \\
\text { of medium- } \\
\text { sized hotels } \\
\text { (USA) } \\
\text { TMT identified } \\
\text { by: } \\
\text { Organization } \\
(\rightarrow \text { real teams) } \\
\text { Average TMT } \\
\text { size: } \\
3.81\end{array}$ & $\begin{array}{l}\text { Analysis: structural } \\
\text { equation modeling } \\
\text { Empowering } \\
\text { leadership } \rightarrow \\
\text { knowledge sharing: + } \\
\text { Empowering } \\
\text { leadership } \rightarrow \text { TMT } \\
\text { efficacy: + } \\
\text { * Knowledge sharing } \\
\rightarrow \text { organizational } \\
\text { performance: + } \\
\text { * TMT efficacy } \rightarrow \\
\text { organizational } \\
\text { performance: }+\end{array}$ \\
\hline $\begin{array}{l}27 . \\
\text { West \& } \\
\text { Anderson } \\
\text { (1996) } \\
\text { Journal of }\end{array}$ & $\begin{array}{l}\text { 1. TMT size } \\
\text { 2. TMT tenure } \\
\text { 3. Proportion of } \\
\text { innovators }\end{array}$ & $\begin{array}{l}\text { Task processes } \\
\text { Team } \\
\text { objectives } \\
\text { (Clarity of and } \\
\text { commitment }\end{array}$ & $\begin{array}{c}\text { Organization level } \\
-\quad \text { Overall } \\
\text { innovation } \\
-\quad \begin{array}{l}\text { Number of } \\
\text { innovations }\end{array}\end{array}$ & $\begin{array}{ll}- & \text { Questionnaires } \\
- & \text { Minutes of } \\
& \text { TMT meetings } \\
- & \text { Audio } \\
& \text { recording of }\end{array}$ & $\begin{array}{l}27 \text { TMTs from } \\
\text { hospitals (UK) } \\
\text { TMT identified } \\
\text { by: }\end{array}$ & $\begin{array}{l}\text { Analysis: multiple } \\
\text { regression analysis } \\
\text { NB. Regressions for } \\
\text { all } 9 \text { outcome }\end{array}$ \\
\hline
\end{tabular}

- 39 - 
Chapter 2

\begin{tabular}{|c|c|c|c|c|c|c|}
\hline $\begin{array}{l}\text { Author(s), } \\
\text { year of } \\
\text { publication, \& } \\
\text { journal of the } \\
\text { study }\end{array}$ & $\begin{array}{l}\text { TMT composition } \\
\text { (selection) \& TMT } \\
\text { structure }\end{array}$ & $\begin{array}{l}\text { TMT processes \& } \\
\text { emergent states }\end{array}$ & Outcome measures & Research methods & $\begin{array}{l}\text { Sample, TMT } \\
\text { identification, } \\
\text { \& average } \\
\text { TMT size }\end{array}$ & $\begin{array}{l}\text { Main results for } \\
\text { relationship TMT } \\
\text { processes and } \\
\text { emergent states to } \\
\text { outcomes }\end{array}$ \\
\hline $\begin{array}{l}\text { Applied } \\
\text { Psychology }\end{array}$ & & $\begin{array}{ll} & \text { to) } \\
- & \text { Participation } \\
- & \text { Task } \\
\text { orientation } \\
\text { - } & \text { Support for } \\
& \text { innovation }\end{array}$ & $\begin{array}{ll}- & \text { Innovation } \\
- & \text { radicalness } \\
\text { Innovation } \\
\text { magnitude } \\
-\quad & \text { Innovation } \\
& \text { novelty } \\
-\quad & \text { Innovation } \\
\text { effectiveness } \\
-\quad & \text { Staff well- } \\
\text { being } \\
-\quad \text { Administrative } \\
\text { effectiveness } \\
\text { Team self- } \\
\text { reports of } \\
\text { innovative- } \\
\text { ness }\end{array}$ & $\begin{array}{l}\text { TMT meetings } \\
\text { NB. Longitudinal } \\
\text { study }\end{array}$ & $\begin{array}{l}\text { CEO } \\
\text { Average TMT } \\
\text { size: } \\
9\end{array}$ & $\begin{array}{l}\text { dimensions and the } 4 \\
\text { task processes as } \\
\text { predictors. } \\
\text { Team objectives } \rightarrow \\
\text { any outcome } \\
\text { measure: } n \text {. s. } \\
\text { Participation } \rightarrow \\
\text { number of } \\
\text { innovations: }+ \\
\text { Participation } \rightarrow \text { team } \\
\text { self-reports of } \\
\text { innovation: }+ \\
\text { Task orientation } \rightarrow \\
\text { administrative } \\
\text { effectiveness: }+ \\
\text { Support for } \\
\text { innovation } \rightarrow \text { overall } \\
\text { innovation: }+ \\
\text { Support for } \\
\text { innovation } \rightarrow \\
\text { innovation novelty: }+ \\
\text { All other } \\
\text { combinations of } \\
\text { processes and } \\
\text { outcome measures: } \\
\text { n. s. }\end{array}$ \\
\hline
\end{tabular}

Notes. * denotes relationship that is included in figure 2.2; n. s. = not significant; $\mathrm{n}$. a. = not applicable; ROA = Return on Assets; ROS = Return on Sales; ROI = Return on Investment 


\section{Results}

\section{Descriptives of Studies in the Review}

In this section, we will describe characteristics of the studies that investigated TMT processes and emergent states that relate to samples, research methods, data analysis, constructs, and measures of the studies.

Samples. The 27 studies in our selection included 29 samples. The sample sizes in these studies ranged between 1 and 402 TMTs with a mean of 77 and standard deviation of 73 . Most studies gathered data from most or all TMT members for an analysis on the team-level. In these cases, the criterion for the inclusion of a TMT in the study was usually that at least two TMT members had answered the administered questionnaires. Exceptions were two studies in which only CEO's were included, whom was asked to rate characteristics of their TMTs without further surveying other TMT members (Janssen et al., 1999; Simsek, Veiga, Lubatkin, \& Dino, 2005). When removing the samples that did not include measures from more than one TMT member (Janssen et al., 1999; Simsek et al., 2005), and samples in which qualitative data were analyzed (Peterson, Owens, Tetlock, Fan, \& Martorana, 1998; Peterson, Smith, Martorana, \& Owens, 2003; Pitcher \& Smith, 2001), the mean sample size was 74 TMTs with a standard deviation of 33. The average team size of the TMTs in these samples ranged from 3.44 (Amason, 1996) to 11 (Bunderson and Sutcliffe, 2003) with a mean of 5.78 TMT members.

From the 29 samples, all but 9 consisted of TMTs from the USA. Exceptions included Israel (Carmeli \& Schaubroeck, 2006), China (Chen et al., 2005), Ireland (Farrell et al., 2005; Flood et al., 2000; Knight et al., 1999) and the Netherlands and Belgium (Hendriks, 2004; Janssen et al., 1999). One study explicitly reported to have investigated TMTs from multinational companies that were based in the USA and had at least five subsidiaries outside the USA (EIron, 1997).

TMTs from a variety of industries have been studied. Particularly well represented were hightechnology firms (Farrell et al., 2005; Hendriks, 2004; Janssen et al., 1999; Knight et al., 1999; Smith et al., 1994), hospitals (Dooley \& Fryxell, 1999; Olson et al., 2007; West \& Anderson, 1996), financial services organizations (Barrick et al., 2007; Pitcher \& Smith, 2001; Rau, 2005), and hotels companies (Simons \& Peterson, 2000; Srivastava et al., 2006). Other industries included those of the consumer products (Bunderson \& Sutcliffe, 2003), food, and manufacturing (Amason, 1996).

Research methods. The research methods used for assessing TMT internal processes and emergent states were mostly the administration of questionnaires by TMT members. Organizational performance indicators were usually provided by the company, or obtained by analyzing annual reports. For the assessment of outcomes on the TMT and decision levels, data were mostly gathered from TMT members.

Data analysis. The data analysis in the studies typically consisted of multiple regression analysis on the TMT level, and sometimes structural equation modeling (Chen et al., 2005; Knight et al., 1999; Simsek et al., 2005). When processes or emergent states were added as a separate step in regression analyses, usually an increase in $R^{2}$ of around .10 was achieved (Amason, 1996; Barrick et al., 2007; Bunderson \& Sutcliffe, 2003; Carmeli \& Schaubroeck, 2006; Dooley \& Fryxell, 1999; Farrell et al., 2005; laquinto \& Fredrickson, 1997). 
Some interesting exceptions were the studies in which the researchers used qualitative techniques for analyzing observational or textual data (Peterson et al., 1998; Peterson et al., 2003; Pitcher \& Smith, 2001). For example, Peterson and colleagues $(1998,2003)$ used their organizational 'Group Dynamics Q-sort' methodology (GDQ). The GDQ consists of 100 items and eight dimensions that describe patterns of TMT dynamics, namely: rigidity - flexibility, control crisis, optimism - pessimism, leader weakness - dominance, factionalism - cohesiveness, legalism corruption, decentralization - centralization, risk averse - risk taking (Peterson et al., 1998; Peterson et al., 2003). With as raw data sources the historic texts about companies and TMTs, multiple raters completed the GDQ and thereby assessed the TMTs under study on the eight dimensions. This methodology is interesting, as it allows for the use of texts as data and a detailed analysis of TMT processes by multiple objective raters instead of relying on the self-reports of TMT members.

Another exception in terms of methodology was Pitcher and Smith's (2001) study with a combination of quantitative and qualitative data of a series of TMTs in one company during eight years. Through the use of observational, archival, interview and questionnaire data from TMT members and key others in the organization, the authors provide a rich account of relationships between top managers' personalities, TMT processes, and organizational performance. In particular, this paper showed how a case study method can be combined with large sample research and the unique knowledge that can be gained from such triangulation of methods.

Notwithstanding the insights gained from these exceptions, the majority of the reviewed studies used cross-sectional designs and static measures for assessing TMT processes and emergent states. This is noteworthy, as a process, by definition, is something which evolves over time and thus could best be captured by repeated measures of activities (Weingart, 1997). An additional problem with cross-sectional designs is that causal effects of processes and emergent states on outcomes cannot be ascertained, amongst others because the effects might become manifest only after a certain time-period. Indeed, some recent studies have incorporated a time-lag in their research design for the effects of TMT processes on outcomes (Rau, 2005; Srivastava et al., 2006), thereby providing more confidence in the conclusion that TMT processes lead to outcomes, instead of the other way around (Amason \& Mooney, 1999; Peterson \& Behfar, 2003). We will come back to the implications of this apparent neglect of a temporal dimension in research on TMT processes when discussing suggestions for future research.

Constructs: task processes. In table 2.2, the definitions of all processes and emergent states that have been studied are presented. Most of the processes were classified as task processes and most of these referred to aspects of TMT decision making. Task conflict, also called cognitive (Amason, 1996; Amason \& Mooney, 1999) or issue-based (Elron, 1997) conflict, has been studied the most, together with two other variables that essentially capture the same construct: dissent (Dooley \& Fryxell, 1999) and debate (Simons et al., 1999). Other task processes have been studied that describe characteristics of decision making even more explicitly: comprehensiveness of decision making (Simons et al., 1999), consensus decision making (Flood et al., 2000; Knight et al., 1999), and agreement seeking (Knight et al., 1999). Other task processes that describe more general characteristics of TMT interaction are knowledge sharing (Srivastava et al., 2006) and communication 
frequency (Smith et al., 1994). Finally, the concept of behavioral integration was studied as a metaconstruct encompassing information exchange, collaborative behavior, and joint decision making (Hambrick, 1994, 2007; Li \& Hambrick, 2005).

Constructs: relationship processes. Constructs referring to TMT relationship processes are informal communication (Smith et al., 1994) and relationship conflict, which was also named affective, emotional, person, or interpersonal conflict (Amason, 1996; Amason \& Mooney, 1999; Barsade et al., 2000; Janssen et al., 1999; Knight et al., 1999; Olson et al., 2007).

Constructs: emergent states. The emergent states that have been studied vary to a larger extent in scope than the task and relationship processes. Therefore, we further classified them as primarily referring to either cognitive or affective aspects of TMT states (e.g., Marks et al., 2001). States that were primarily cognitive in nature included TMT cooperativeness (Barsade et al., 2000), learning orientation (Bunderson \& Sutcliffe, 2003), competence (Dooley \& Fryxell, 1999), loyalty (Dooley \& Fryxell, 1999), agreement (laquinto \& Fredrickson, 1997), expertise location (Rau, 2005), efficacy (Srivastava et al., 2006), norms of openness and mutuality (Amason \& Mooney, 1999), and strategic consensus (Knight et al., 1999).

Emergent states that were primarily affective in nature included social integration and cohesion. In one study, social cohesion was explicitly defined as an emergent state, but could in a factor analysis not be clearly distinguished from 'communication' and the authors combined the two constructs under the heading of 'team mechanisms' (Barrick et al., 2007), which we classified as a task process. The emergent state of intra-TMT trust has both a cognitive and an affective component. Partly reflecting the variety of existing conceptualizations of trust in the larger trust literature (Rousseau, Sitkin, Burt, \& Camerer, 1998), researchers in the reviewed studies have used slightly different ways to conceptualize intra-TMT trust (Farrell et al., 2005; Olson et al., 2007; Rau, 2005). Without going into an in-depth analysis of the trust construct (but see Mayer, Davis, \& Schoorman, 1995; Rousseau et al., 1998), we assume that all studies have essentially captured a similar construct of generalized expectations of trust among the TMT members and we will treat the outcomes of the studies as comparable.

Measures. A variety of measures has been used to capture TMT processes and emergent states. Given the fact that many constructs were only used in one study, researchers have developed their own scales for measuring these constructs, often based on existing measures of team processes in research on nonmanagerial teams (Smith et al., 1994). An exception is relationship conflict, which has always been measured by using Jehn's (1995) four-item scale for this construct (Amason, 1996; Amason \& Mooney, 1999; Janssen et al., 1999; Knight et al., 1999; Olson et al., 2007; Rau, 2005; Simons \& Peterson, 2000). Another construct that has been measured in a consistent way is behavioral integration (Carmeli \& Schaubroeck, 2006; Simsek et al., 2005), but this is to date relatively new to the literature and has been related to outcomes in only two studies (Carmeli \& Schaubroeck, 2006; Lubatkin, Simsek, Yan, \& Veiga, 2006)

Results. Figure 2.2 provides a summary of the direction and significance of the investigated direct effects of task processes, relationship processes, and emergent states on organizational, TMT,

\footnotetext{
${ }^{6}$ It has also been shown to relate to firm performance for new venture TMTs (Li \& Hambrick, 2005), but the studies on new venture TMTs are not reviewed here.
} 
and decision outcomes. To ensure comparability, we report only results from studies on the TMT level that were analyzed via regression and structural equation analyses and in which processes and emergent states were modeled as determinants of TMT outcomes. This involves 19 studies from the original selection of 28 studies, in which in total 59 direct-effect relationships were investigated. The results from the remaining studies will be considered separately. Figure 2.2 shows that mostly relationships between task processes and outcomes (27 relationships) and between emergent states and outcomes (24 relationships) have been studied; relationship processes have been studied the least (8 relationships). To get a more detailed insight into the variables that had shown significant relationships to outcomes, table 2.3 specifies which TMT processes and emergent states were found to be significantly related to outcomes as well as the direction of the effects. Thus, whereas figure 2.2 presents an overview of al/ relationships, table 2.3 contains significant relationships only.

In the following, we will first discuss the main effects of task processes, relationship processes, and emergent states on outcomes. Next, we will review other findings regarding the potentially moderating role of outcome levels, sample characteristics, and relationships among different processes and emergent states.

\section{Effects of TMT Task Processes on Outcomes}

All task processes in the studies were hypothesized to be positively related to outcomes, because they were proposed to increase the quality and amount of information during decision making. For decision outcomes, such positive effects were found indeed: ten times a positive effect was found, whereas only one relationship (i.e., between cognitive conflict and decision commitment, Amason, 1996) was not significant. Moreover, no unexpected, opposite effects were found with regard to task processes and decision outcomes. The task processes task conflict, dissent, and debate (Amason, 1996; Dooley \& Fryxell, 1999; Olson et al., 2007; Simons et al., 1999), all referring to the open discussion of differences of opinion about the task or decision at hand, were associated with better decision quality, understanding, and decision comprehensiveness, and sometimes with higher commitment to the decision. However, one of the three relationships for decision commitment was not significant. Behavioral integration, which captures the degree to which mutual and collective interaction exists in a TMT, also had a positive effect on TMT members' perceptions of decision quality (Carmeli \& Schaubroeck, 2006).

Task processes were also found to positively relate to TMT and organizational outcomes. Consensus decision making (Flood et al., 2000) and productive conflict (Chen et al., 2005) both contributed to TMT members' higher perceptions of team effectiveness. Accurate communication (Hendriks, 2004) and knowledge sharing within the TMT (Srivastava et al., 2006) positively related to organizational performance. Behavioral integration was associated with less organizational decline (Carmeli \& Schaubroeck, 2006) and with a higher ambidextrous orientation of organizations (Lubatkin et al., 2006). Thus, when decision making is focused on reaching consensus and when conflict is perceived to be managed satisfactorily, TMT members perceive their team to perform well. The more TMT members perceive that information is openly shared among the members and that the information exchanged is accurate, the higher organizational performance. When more mutual and collective interaction exists among TMT members, they perceive less organizational decline. 
Table 2.2. Definitions of investigated constructs classified as task processes, relationship processes, and emergent states

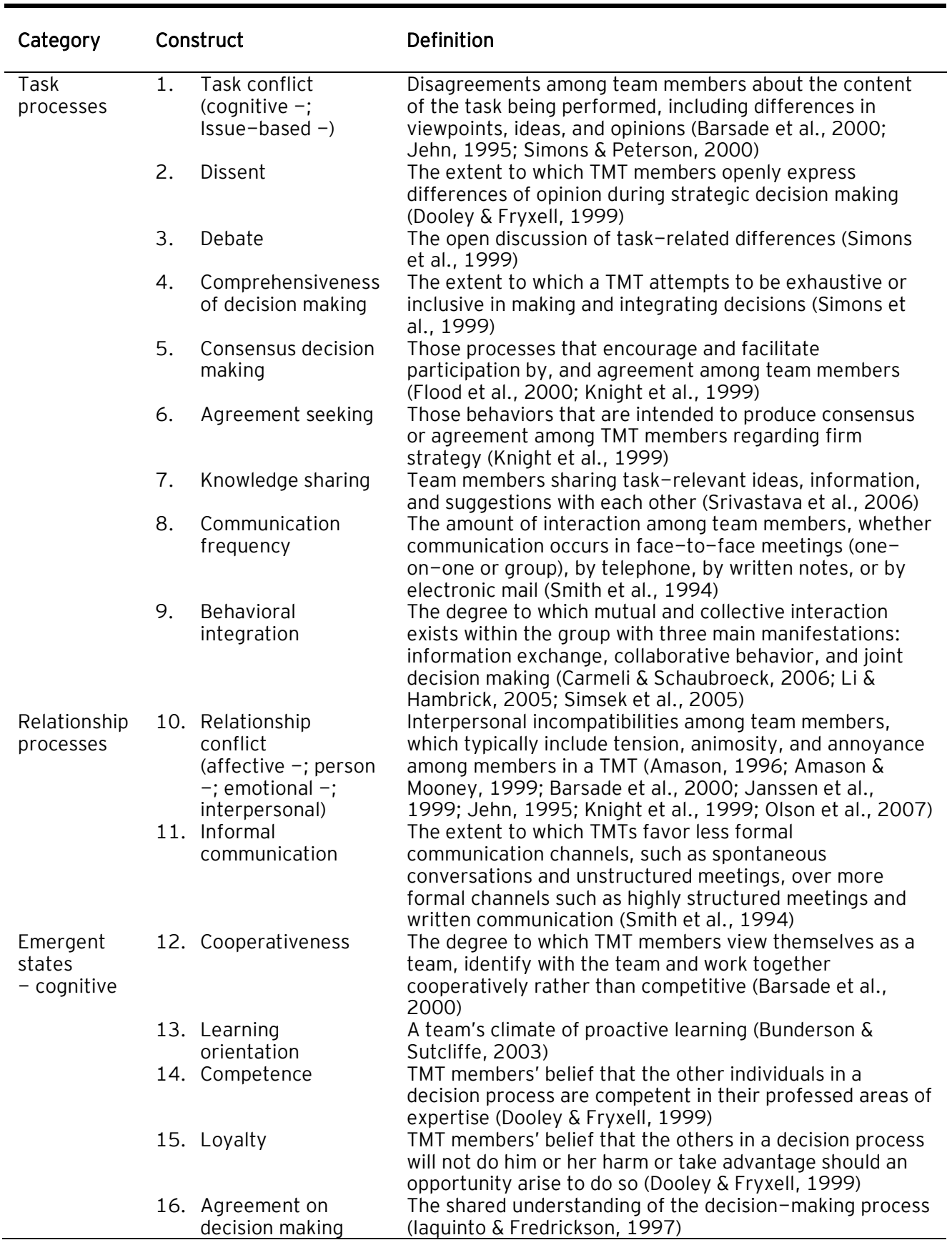




\begin{tabular}{|c|c|c|}
\hline Category & Construct & Definition \\
\hline \multirow{10}{*}{$\begin{array}{l}\text { Emergent } \\
\text { states } \\
\text { - affective }\end{array}$} & 17. Expertise location & $\begin{array}{l}\text { TMT members' awareness of the location of expertise in } \\
\text { the team, i.e.. knowing who knows what (Rau, 2005) }\end{array}$ \\
\hline & 18. Team efficacy & $\begin{array}{l}\text { The belief of team members in their joint capability of } \\
\text { executing certain behaviors necessary to attain a desired } \\
\text { level of performance on specific tasks (Srivastava et al., } \\
\text { 2006) }\end{array}$ \\
\hline & 19. Openness norms & $\begin{array}{l}\text { The TMT's willingness to engage in frank and tolerant } \\
\text { interaction (Amason \& Mooney, 1999) }\end{array}$ \\
\hline & 20. Mutuality norms & $\begin{array}{l}\text { The extent to which group members see themselves as } \\
\text { being mutually responsible and accountable for their } \\
\text { actions (Amason \& Mooney, 1999) }\end{array}$ \\
\hline & $\begin{array}{l}\text { 21. Strategic } \\
\text { consensus }\end{array}$ & $\begin{array}{l}\text { Agreement or overlap among individual team members' } \\
\text { mental models of strategy, but not necessarily implying a } \\
\text { deliberative consensus-seeking process (Knight et al., } \\
\text { 1999) }\end{array}$ \\
\hline & 22. Social integration & $\begin{array}{l}\text { The attraction to the TMT, satisfaction with other } \\
\text { members of the TMT, and social interaction among the } \\
\text { TMT members (O'Reilly, Caldwell, \& Barnett, 1989; Smith } \\
\text { et al., 1994) }\end{array}$ \\
\hline & 23. Social cohesion & $\begin{array}{l}\text { - An affective, psychological state that reflects the } \\
\text { shared commitment, attraction, and team pride that } \\
\text { emerges from the experiences and interactions } \\
\text { among team members (Barrick et al., 2007) } \\
\text { The degree to which TMT members are attracted to } \\
\text { - each other (EIron, 1997; Hendriks, 2004) }\end{array}$ \\
\hline & \multirow[t]{3}{*}{ 24. Intra-TMT trust } & $\begin{array}{l}\text { The expectations, assumptions, or beliefs about the } \\
\text { likelihood that another's future actions will be } \\
\text { beneficial, favorable, or at least not detrimental to } \\
\text { one's interests (Rau, 2005) }\end{array}$ \\
\hline & & $\begin{array}{l}\text { - A construct being based on the cognitive process of } \\
\text { choosing whom we will trust (Olson et al., 2007) }\end{array}$ \\
\hline & & $\begin{array}{l}\text { A construct being based on perceptions of TMT } \\
\text { members' ability, benevolence, and integrity (Farrell } \\
\text { et al., 2005; Mayer et al., 1995) }\end{array}$ \\
\hline
\end{tabular}




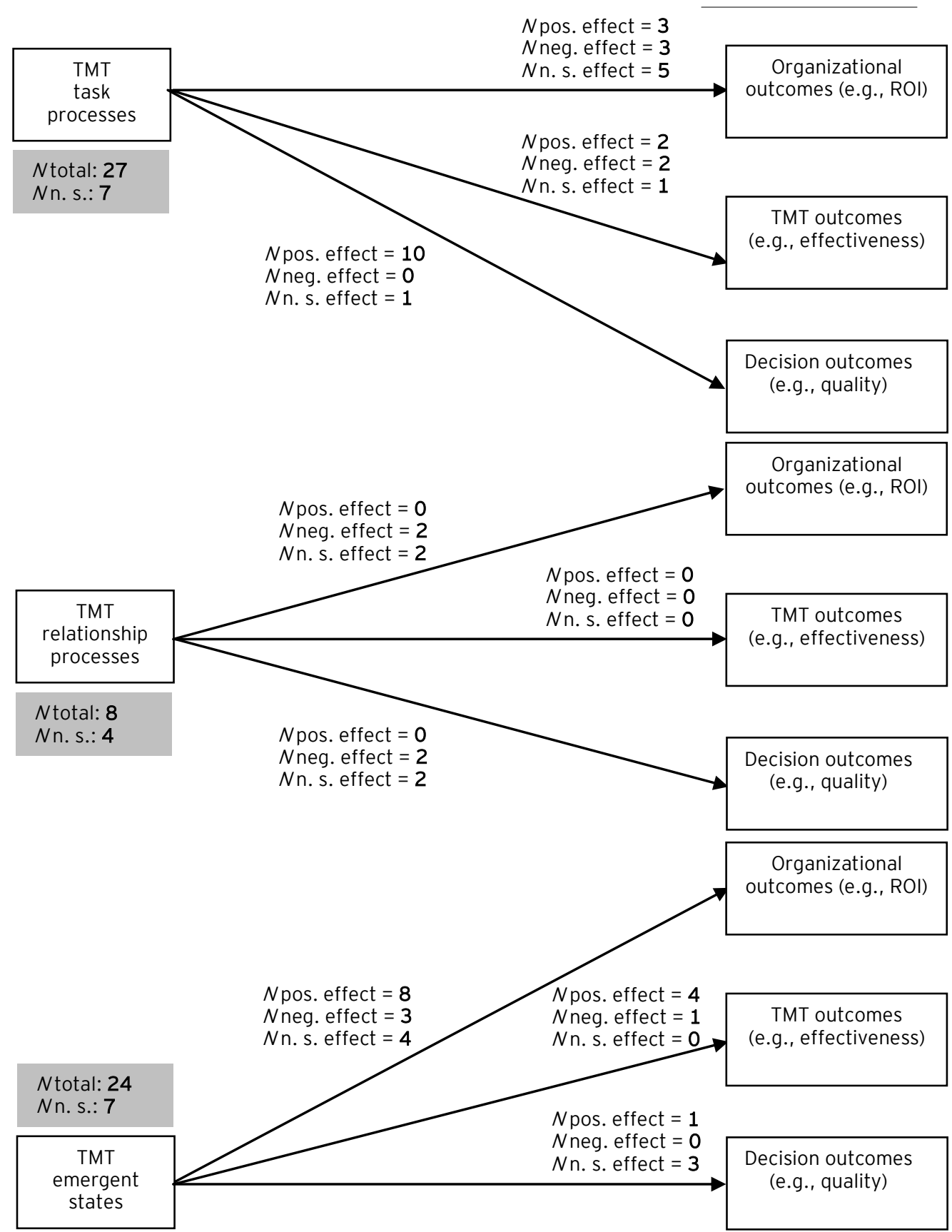

Notes. Relationships of West and Anderson (1996) are not incorporated in figure 2.2 due to the large number of tested relationships in this study (54), which would inflate the results; $\mathrm{ROI}=$ Return on Investment; n. s. = not significant

Figure 2.2. Number of positive, negative, and non significant relationships of TMT task and relationship processes and emergent states to TMT outcomes. 
Table 2.3. Overview of task processes, relationship processes, and emergent states, which have shown a significant positive or negative relationship to organizational, TMT, and decision outcomes

\begin{tabular}{|c|c|c|c|c|}
\hline & & $\begin{array}{c}\text { Organizational outcomes } \\
\text { (e.g., ROI) }\end{array}$ & $\begin{array}{l}\text { TMT outcomes } \\
\text { (e.g.. } \\
\text { effectiveness) }\end{array}$ & $\begin{array}{l}\text { Decision outcomes } \\
\text { (e.g., quality) }\end{array}$ \\
\hline \multirow[t]{2}{*}{$\begin{array}{l}\text { Task } \\
\text { processes }\end{array}$} & $\begin{array}{l}\text { Positive } \\
\text { effect }\end{array}$ & $\begin{array}{ll}- & \text { Accurate } \\
\text { communication } \\
\text { (Hendriks, 2004) } \\
\text { - } \quad \text { Knowledge sharing } \\
\text { (Srivastava et al., } \\
\text { 2006) } \\
\text { Behavioral } \\
\text { integration (Carmeli } \\
\text { \& Schaubroeck, } \\
\text { 2006; Lubatkin et } \\
\text { al., 2006) }\end{array}$ & $\begin{array}{ll}- & \text { Consensus } \\
\text { decision } \\
\text { making (Flood } \\
\text { et al., 2000) } \\
\text { Productive } \\
\text { conflict (Chen } \\
\text { et al., 2005) }\end{array}$ & $\begin{array}{ll}\text { - } & \text { Task conflict } \\
& \text { (Amason, 1996; } \\
\text { Olson et al., } \\
\text { 2007) } \\
\text { - } \quad \text { Dissent (Dooley \& } \\
\text { Fryxell, 1999) } \\
\text { - } \quad \text { Debate (Simons } \\
\text { et al., 1999) } \\
\text { - Behavioral } \\
\text { integration } \\
\text { (Carmeli \& } \\
\text { Schaubroeck, } \\
\text { 2006) }\end{array}$ \\
\hline & $\begin{array}{l}\text { Negative } \\
\text { effect }\end{array}$ & $\begin{array}{ll}\text { - } & \text { Communication } \\
\text { frequency (Smith et } \\
\text { al., 1994) } \\
\text { - } \quad \text { Team mechanisms } \\
\text { (Barrick et al., 2007) }\end{array}$ & $\begin{array}{ll}- & \text { Task conflict } \\
\text { (Elron, 1997) } \\
\text { - } \quad \text { Team } \\
\text { mechanisms } \\
\text { (Barrick et } \\
\text { al., 2007) } \\
\end{array}$ & n. a. \\
\hline \multirow[b]{2}{*}{$\begin{array}{l}\text { Relationship } \\
\text { processes }\end{array}$} & $\begin{array}{l}\text { Positive } \\
\text { effect }\end{array}$ & n. a. & n. a & n. a. \\
\hline & $\begin{array}{l}\text { Negative } \\
\text { effect }\end{array}$ & $\begin{array}{ll}- & \text { Relationship conflict } \\
\text { (Rau, 2005) } \\
-\quad \text { Informal } \\
\text { communication } \\
\text { (Smith et al., 1994) }\end{array}$ & n. a. & $\begin{array}{l}\text { Relationship conflict } \\
\text { (Amason, 1996) }\end{array}$ \\
\hline \multirow[t]{2}{*}{$\begin{array}{l}\text { Emergent } \\
\text { states }\end{array}$} & $\begin{array}{l}\text { Positive } \\
\text { effect }\end{array}$ & $\begin{array}{ll}- & \text { TMT trust (Farrell et } \\
& \text { al., 2005) } \\
- & \text { Centralization } \\
& \text { (Hendriks, 2004) } \\
- & \text { TMT agreement } \\
& \text { (laquinto \& } \\
& \text { Fredrickson, 1997) } \\
-\quad & \text { Expertise location } \\
\text { (Rau, 2005) } \\
\text { - } \quad \text { Social integration } \\
\text { (Smith et al., 1994) } \\
\text { TMT efficacy } \\
\text { (Srivastava et al., } \\
\text { 2006) }\end{array}$ & $\begin{array}{ll}\text { - } & \text { Social } \\
\text { cohesion } \\
\text { (Elron, 1997; } \\
\text { Hendriks, } \\
\text { 2004) } \\
\text { Social } \\
\text { integration } \\
\text { (Flood et al., } \\
\text { 2000) } \\
\text { Centralization } \\
\text { (Hendriks, } \\
\text { 2004) }\end{array}$ & $\begin{array}{l}\text { Competence (Dooley } \\
\text { \& Fryxell, 1999) }\end{array}$ \\
\hline & $\begin{array}{l}\text { Negative } \\
\text { effect }\end{array}$ & $\begin{array}{ll}- & \text { Team } \\
\text { interdependence } \\
\text { (Barrick et al., 2007) } \\
\text { Team learning } \\
\text { orientation } \\
\text { (Bunderson \& } \\
\text { Sutcliffe, 2003) }\end{array}$ & $\begin{array}{l}\text { Team } \\
\text { interdependence } \\
\text { (Barrick et al., } \\
\text { 2007) }\end{array}$ & n. a. \\
\hline
\end{tabular}

Notes. Relationships of West and Anderson (1996) are not incorporated in this table due to the large number of tested relationships (54), which would inflate the results; ROI = Return on Investment; n. a. = not applicable 
Some relationships between task processes and outcomes were not significant and some were even in the opposite direction. Task conflict had a negative rather than the expected positive effect on TMT performance in one study (Elron, 1997) and communication frequency was unexpectedly negatively related to organizational performance (Smith et al., 1994). In response to the negative effect of task conflict (Elron, 1997), the authors examined the effects of task conflict on subsequent organizational performance - a relationship that had not been hypothesized in their original model and found a positive relationship. The negative relationship between task conflict and self-perceived TMT effectiveness and the positive relationship between task conflict and organizational performance could indicate that self-perceptions of TMT effectiveness merely represent TMT members' satisfaction with the TMT process and that task conflict is negatively related to satisfaction (Elron, 1997). It might also imply that the relationship between task conflict and self-perceived TMT effectiveness does not only exist in researchers' analyses of TMT functioning, but also in the minds of TMT members, which is reflected in their answers on the questionnaire (Staw, 1975; Weingart, 1997). This suggests a necessity for careful consideration of the outcome measures chosen, as well as the specification of the mechanisms that are expected to lead to these outcomes. Common source and common method biases should also be considered (Podsakoff, Mackenzie, Lee, \& Podsakoff, 2003), as these are possible concerns when interpreting these relationships.

Communication frequency also had an unexpected negative relationship to organizational performance (Smith et al., 1994). Whereas the authors had expected that frequent communication would be beneficial for high-speed decision making in the fast-paced environment in which the TMTs in their sample operated, the opposite was found: less frequent communication was related to better organizational performance. Thus, it might be that frequent TMT communication is an indicator for conflict and disagreement, which could lead TMT members to react with "a flurry of meetings and written memos that detract from task-oriented activities" (Smith et al., 1994, p. 432). Infrequent communication would then indicate that the team is working well with little need for information exchange and communication (Smith et al., 1994).

A later study possibly sheds more light on the negative effect of communication frequency. Namely, team mechanisms, consisting of cohesion and communication (Barrick et al., 2007), were also found to be negatively related to TMT and organizational performance. This effect only occurred when interaction effects between team mechanisms and interdependence were included in the regression analyses. Inspection of the interaction effects showed that when interdependence was high, team mechanisms had a positive impact on TMT and organizational performance; when interdependence was low, team mechanisms had a negative impact. The interaction effects also differ somewhat depending on the outcome measure used: when considering TMT performance, TMTs with high levels of both interdependence and team mechanisms (i.e., high cohesion and communication) outperform team with low interdependence regardless of the level of team mechanisms. When considering firm performance, the case is more extreme. With low interdependence, increased team mechanisms are related to lower performance; with high interdependence, increased team mechanisms have a positive effect, but performance only rises to the same level of teams with low interdependence and low team mechanisms. In case the TMTs in the sample of Smith and colleagues 
(1994), were low in interdependence, these results might explain their unexpected findings. We will discuss the role of TMT interdependence in more detail later on in this chapter.

In summary: 1) TMT interaction that is characterized by dissent and task-related disagreements benefits strategic decision making. However, it does not always translate into better TMT and organizational performance. 2) The effects of task processes on different outcomes vary, pointing at the need for an explicit consideration of the outcome levels chosen (Barrick et al., 2007; Elron, 1997) and more insight in the mechanisms by which these outcomes are achieved. 3) Interdependence, as an aspect of TMT structure, can moderate relationships between TMT task processes and outcomes, showing that increased cohesion and communication are only beneficial for TMTs that are highly interdependent.

\section{Effects of TMT Relationship Processes on Outcomes}

As relationship processes, the constructs of relationship conflict and informal communication have been studied. Relationship conflict was found to significantly and negatively relate to decision quality and the affective acceptance of decisions (Amason, 1996), and, on the organizational level, return on assets (Rau, 2005). On the decision level, the proposed negative effects of relationship conflict on decision understanding and -commitment were not found (Amason, 1996). On the organizational level, relationship conflict did not have the expected negative effect on market adjusted return (Barsade et al., 2000). Relationship conflict was also studied on the individual level, as a single TMT member's perception of conflict in the TMT as a whole (Janssen et al., 1999). In this study, perceptions of relationship conflict were negatively related to perceptions of integrative behavior, decision quality, and affective acceptance of decisions and positively to distributive conflict behavior, which was defined as the extent to which TMT members try to maximize unequal outcomes (Janssen et al., 1999).

Thus, for relationship conflict, it can be said that although not all effects were significant, if a significant effect was found, it was always in the expected direction. We could not detect any systematic relationship between the significance of the findings and the type of outcome measures or characteristics of the sample. Furthermore, relationship conflict was found to be negatively related to the task process of TMT agreement seeking (Knight et al., 1999) and was significantly and positively associated with task conflict (Amason, 1996; Amason \& Mooney, 1999; Olson et al., 2007; Simons \& Peterson, 2000).

For the other relationship process that has been studied, informal communication, an unexpected negative effect was found on sales growth and return on investment (Smith et al., 1994). While the authors had expected a positive effect, because of the lower needs for coordination and control implied by informal communication, apparently, TMTs might need a certain degree of formality in communication to ensure frequent information exchange, even when they are socially integrated (Smith et al., 1994). Alternatively, informal communication could indicate the existence of intra-TMT politics, which may detract time and energy from productive task work and lead to decreased performance (Eisenhardt \& Bourgeois, 1988). 
In summary: 1) TMT processes that are characterized by interpersonal animosities are never beneficial for TMT outcomes in terms of decision quality and organizational performance, but they do not always harm either. 2) The negative effect of relationship conflict could theoretically be mitigated through its positive association with task conflict, which was found to positively relate to outcomes. However, since relationship conflict is also negatively related to agreement seeking in decision making, it might in practice be hard to positively influence outcomes when having relationship conflict in the TMT. 3) Informal communication might be a detrimental rather than a beneficial aspect of TMT interaction; however, more research is needed to corroborate findings on its effects.

\section{Effects of TMT Emergent States on Outcomes}

Although the term 'emergent state' is relatively new to the TMT literature (Barrick et al., 2007; Srivastava et al., 2006), we found numerous studies that had in fact measured such states. In the analysis of the main results, 24 relationships were found. Emergent states have been linked most often to organizational outcomes (15 times), and less to TMT (5 times) and decision (4 times) outcomes. Most emergent states were hypothesized and found to be positively related to outcomes.

Emergent states of a cognitive nature for which significant positive effects on outcomes were found, included TMT efficacy on organizational performance (Srivastava et al., 2006), TMT competence on decision commitment (Dooley \& Fryxell, 1999), TMT agreement on ROA (laquinto \& Fredrickson, 1997), and expertise location on ROA (Rau, 2005). Cognitive emergent states for which no significant relationships to outcomes were found, included the effect of competence on decision quality, those of loyalty on decision quality and -commitment (Dooley \& Fryxell, 1999), and the effect of cooperativeness on market adjusted return (Barsade et al., 2000).

Finally, team learning orientation was studied with the aim of testing a non-linear and moderating relationship to outcomes (Bunderson \& Sutcliffe, 2003). Although a negative main effect was found for learning orientation on the organizational level outcomes of performance-to-plan and profit-per-unit, the effects that the authors had hypothesized and found in their sample were nonlinear. Their theoretical rationale and empirical results show that although a learning orientation is positive for a team, from a certain point onward, it distracts time and energy from task behavior in which case team performance will decrease. Additionally, the relationship between learning orientation and performance is moderated by past performance in such a way that teams with lower past performance benefit more from a learning orientation than teams with higher past performance (Bunderson \& Sutcliffe, 2003).

Emergent states of an affective nature included social integration and cohesion. When TMTs were more cohesive and socially integrated as perceived by the TMT members, these members also reported the TMT to be more effective (Elron, 1997; Flood et al., 2000) and have less project problems (Hendriks, 2004). An increase in their organization's ROI and sales growth was also observed (Smith et al., 1994). In one case, however, the expected positive effect of cohesion on firm performance was not significant (Hendriks, 2004). Barrick and colleagues' (2007) study, in which cohesion and communication were combined into a single factor, suggests that the relationship between cohesion and performance might be moderated by TMT interdependence. 
Intra-TMT trust, an emergent state with both cognitive and affective components, was only studied in relation to outcomes in two studies (Farrell et al., 2005; Rau, 2005). Farrell and colleagues' (2005) results showed that trust was positively related to one measure of organizational learning, namely employees' ability to combine and exchange information, but not to their other measure, employees' motivation to combine and exchange information. Rau (2005) found no significant relationship between TMT trust and ROA. Other studies on trust that did not aim to establish a relationship between trust and outcomes, showed a positive relationship between trust and task conflict (Olson et al., 2007), a negative relationship between trust and relationship conflict (Simons \& Peterson, 2000), and an interaction effect of trust and task conflict on relationship conflict, such that the correlation between task and relationship conflict was higher when intra-TMT trust was low (Simons \& Peterson, 2000).

In summary: 1) Cognitive states that indicate increased confidence of TMT members in the team and in each other and having a team-level information system in place where TMT members know who knows what and understand their work in a similar way, seem to benefit organizational outcomes. However, since all relationships have been studied only once, the conclusions about the effects of any single state on outcomes should be interpreted tentatively. 2) For affective states, it seems that TMT cohesion would rather have a positive than a negative effect on outcomes, even more so when teams are highly interdependent. Thus, when TMTs experience a state of shared commitment, attraction, and team pride and TMT members are attracted to each other, performance benefits. However, since not all relationships were significant, the results should be interpreted tentatively. 3) The effects of trust on outcomes are indirect via its relation to processes such as task and relationship conflict, rather than direct, which was also suggested by recent research on nonmanagerial teams (De Jong, 2007; Dirks, 1999; Langfred, 2004).

\section{Moderators: TMT Structure and the Teamness of TMTs}

Some constructs in the studies described structural characteristics of the TMT: TMT interdependence and decision centralization. TMT interdependence is "the extent to which contextual features outside an individual and his or her behavior (i.e., tasks and outcomes) define a relationship between entities as collective, so that one entity should affect and be affected by the other" (Barrick et al., 2007, p. 546). Janssen and colleagues (1999, p. 117) have referred to the related construct of 'positive interdependence' as 'the perceived positive relation between the attainment of one's own and the other's goals". TMT interdependence moderated the relationships between team mechanisms - cohesion and communication - and TMT- and organizational-level outcomes (Barrick et al., 2007). The other study that also investigated interdependence - albeit with a single TMT member as data source instead of the whole TMT - proposed a direct relationship between interdependence and team decision effectiveness and suggested that team processes moderated this relationship (Janssen et al., 1999). This study's significant three-way interaction effect led the authors to suggest that interdependence is particularly important for a positive impact on team outcomes when task and relationship conflict interfere, but less so in situations where only task conflict, only relationship conflict, or no conflict at all exist. 
Decision centralization has been described as the degree to which decision rights and opportunities formally rest with the one person that is highest in the hierarchy versus are equally divided among all team members (Bunderson, 2003; Hendriks, 2004). This variable was positively related to firm profitability and negatively to project problems (Hendriks, 2004). Thus, there seem to be outcome benefits from centralized decision making, possibly relating to the proposed positive effects of a certain degree of formality in communication discussed earlier (Smith et al., 1994). However, an opposite conclusion was drawn from Pitcher and Smith's (2001) eight year multimethod study. These authors document how subsequent TMTs, with different members, in one organization increasingly relied on centralized decision-making processes and formalized procedures. This was detrimental to innovation and company performance. Investigating decision centralization as a structural characteristic that could shape TMT processes and emergent states has been proposed as a necessary step for TMT research (Bunderson, 2003; Finkelstein, 1992). The seemingly contradictory findings from the studies included in this review support the need for further research.

We also mentioned earlier that differences might exist between TMTs in their degree of 'teamness'. Although it was not possible to analyze if the TMTs under study were interdependent in their tasks, had clear boundaries and were reasonably stable over time - criteria for the extent to which a TMT is a real team (Wageman et al., 2008) - due to a lack of information, we did find some teams that clearly existed as distinct social entities in their organizations (Bunderson \& Sutcliffe, 2003; Srivastava et al., 2006) and studies in which the degree of 'teamness' was explicitly investigated (Barrick et al., 2007; Carmeli \& Schaubroeck, 2006; Simsek et al., 2005). Yet, most of the teams were identified by the CEOs and might or might not exist in their organizations as distinct social entities. Two variables that we discussed before and which could be indicators for teamness of TMTs are interdependence and behavioral integration. As interdependence was found to be a moderator for the effects of communication and cohesion on organizational performance (Barrick et al., 2007) and positive effects were found of TMT behavioral integration on outcomes (Carmeli \& Schaubroeck, 2006), more attention to the degree of teamness of TMTs seems warranted. These constructs could then be modeled as moderators of the relationships between processes, emergent states, and outcomes to possibly clarify current conflicting findings.

\section{Moderators: Characteristics of Research Designs and Samples}

In the previous section, we have discussed TMT structure and TMT teamness as potential moderators of the relationships between internal processes and states to outcomes that could possibly explain inconsistent empirical results with regard to these relationships. However, other reasons for such inconsistent results might relate to characteristics of the research designs and samples. In the following, we will discuss if differences in the outcome measures that were used or differences with regard to the country in which the TMTs operated systematically influenced the results.

Outcome measures. Multiple outcomes of TMT processes and emergent states have been proposed and tested, which we categorized in this review as organizational, TMT, and decision outcomes, and we wanted to see if the type of outcome measure was related to the reported effects 
of processes and emergent states. The majority of the investigated relationships (30) involved outcomes on the organizational level, while 10 relationships involved outcomes on the TMT level, and 19 relationships involved decision outcomes. Two studies showed differential effects based on the outcome measures that were chosen (Barrick et al., 2007; Elron, 1997). Relatively more non significant relationships were reported for organizational level outcomes than for decision and TMT outcomes. In some cases, different outcome measures were explicitly found to be related to each other. For example, firm ambidextrous orientation was positively related to firm performance (Lubatkin et al., 2006), decision quality was negatively related to organizational decline (Carmeli \& Schaubroeck, 2006), TMT effectiveness was positively related to organizational innovation (Chen et al., 2005), and TMT self-perceived performance was positively related to organizational performance (Elron, 1997).

The variety of outcome measures included in the reviewed studies and the conflicting findings regarding the effects of processes and states on different outcomes have led to at least two considerations. First, researchers need to carefully select the outcomes of interest to study the effects of processes and emergent states. For some processes or states that capture subtle differences in TMT interaction, one might expect effects on the decision level, but perhaps not on a distal measure of organizational performance. For some processes or states, it might be appropriate to select an outcome on the team level, whereas for other processes, one might prefer the objective nature of financial measures of organizational performance. Second, there seems to be a need for a comprehensive model for assessing the extent to which a TMT is performing well. Such a model should acknowledge the multi-dimensional nature of TMT performance (e.g., Edmondson et al., 2003) and could inform more detailed models of TMT impact. By acknowledging that TMTs might be good in some aspects of their work, but do less well on others, more detailed insight regarding the effects of processes and states on outcomes could be gained.

Differences between countries and industries. No systematic differences in results or studied variables could be identified between the studies that investigated US versus non-US samples (Carmeli \& Schaubroeck, 2006; Chen et al., 2005; Elron, 1997; Farrell et al., 2005; Hendriks, 2004). Thus, although there is a clear need to expand TMT research beyond the US (Hambrick, 2007), no indication so far has been found that existing theory on TMT processes and states is not generalizable across national and cultural settings.

Researchers have also argued that differences in the industries in which organizations operate might enhance or decrease the impact TMTs can have on their organizations. In particular, in industries that are dynamic and uncertain, TMTs are expected to have more discretion in influencing outcomes than in industries that are more stable (Carpenter et al., 2004; Finkelstein \& Hambrick, 1990). In our sample, 7 of the 27 studies could be identified as having been performed in an highdiscretion environment, namely those in the computer and high technology industries (e.g., Finkelstein \& Hambrick, 1990; Smith et al., 1994).

When inspecting table 2.1 and comparing significant versus non significant relationships in these 7 studies (Amason \& Mooney, 1999; Farrell et al., 2005; Flood et al., 2000; Hendriks, 2004; Knight et al., 1999; Simons et al., 1999; Smith et al., 1994) to those in the other studies, no clear differences could be observed. When inspecting the significant relationships in table 2.3 , relationships 
from these 7 studies are well-represented, but each cell of the table also contains relationships from other studies. Therefore, we conclude that the effects of TMT processes and states on outcomes are not visibly traceable to the industry in which a TMT works.

\section{Relationships among Task and Relationship Processes and Emergent States}

We have reasoned that task and relationship processes and emergent states are not independent. Task-related discussions carry interpersonal messages and interpersonal relationships may be expressed during task behavior. Furthermore, team emergent states are both the result of processes and the input to them (Marks et al., 2001). Several of our results support this notion.

First, in the studies that investigated both task and relationship processes - most notably, task and relationship conflict - correlations between these processes varied between .38 and .70 (Amason, 1996; Amason \& Mooney, 1999; Olson et al., 2007), which also reflects earlier findings from nonmanagerial teams (De Dreu \& Weingart, 2003). Second, in one study the emergent state of cohesion and the task process of communication could not be distinguished from each other and loaded on one factor in a factor analysis (Barrick et al., 2007). Third, the construct of behavioral integration has been proposed as an all-inclusive construct to capture the extent to which a TMT shares information, resources, and decision responsibilities and its measures have shown good psychometric properties in previous research as well as explanatory value in outcomes (Carmeli \& Schaubroeck, 2006; Hambrick, 2007; Simsek et al., 2005). These findings all suggest that various processes and emergent states should explicitly be studied in relation to each other. Failing to address these interdependencies might lead to an incomplete picture of the interactions of a TMT.

Most studies have looked at processes and emergent states in isolation and it is not clear if certain underlying patterns jointly influence outcomes. Some indication for the meaningfulness of studying broad patterns of processes comes from the studies of Peterson and colleagues (Peterson et al., 1998; Peterson et al., 2003) who used archival sources and a Q-sort methodology to assess how characteristics of TMT interaction influenced organizational outcomes. Their results show that TMT processes that are characterized by more flexibility, optimism, cohesiveness, and risk taking are associated with better organizational performance. Moreover, they showed that the process dimensions of the GDQ were moderately to strongly correlated (Peterson et al., 1998). Thus, it seems worthwhile to investigate relationships among processes and emergent states, which could make the resulting effects of possible counteracting forces of task and relationship processes and emergent states more clear.

\section{Conclusion: What Is Known?}

Despite the difficulty to get access to TMTs for gathering information about their internal processes (Hambrick, 2007; Pettigrew, 1992), the 27 studies included in table 2.1 demonstrate that researchers in the last ten years have managed to do so. The results of this review show that a considerable number of these processes and emergent states are significantly related to outcomes on organizational, TMT, and decision levels. Together they add to our understanding of the determinants of TMTs' impact on their organizations. 
Most notably, task processes characterized by task-related differences of opinion during strategic decision making lead to better decision outcomes and, sometimes, to better TMT and organizational outcomes. Interpersonal tensions and animosities as part of relationship conflict can, but not always do, undermine positive decision outcomes and even outcomes on the organizational level. When TMTs experience states in which members are confident of themselves and the team, and when they know who knows what, organizational performance is high relative to TMTs that experience these states less. When TMT members are in a state of attraction and shared commitment, performance also benefits. Intra-TMT trust seems to play a role as well, but the effects on outcomes are indirect rather than direct. The degree of interdependence among TMT members can determine the effects of processes and emergent states on outcomes.

\section{Conclusion: What Is Not Yet Known?}

We found that a number of investigated relationships between processes and outcomes was not significant and some effects were even significant in the opposite direction. These inconsistent results were not systematically related to country differences in the samples, or to differences in outcome levels. Since most constructs were only incorporated in one or a few studies, it is difficult to analyze whether inconsistent results are due to sample characteristics or suggest underlying theoretical concerns. Additionally, we also see other fundamental issues in the current state of the literature that limit our insight in how the processes and states influence outcomes.

First, insufficient insight exists in the potential moderating role of TMT structure in the relationship between processes and emergent states and outcomes. Although team structure has been proposed as a determinant for process - outcome relationships, both in research on TMTs (Finkelstein, 1992) and nonmanagerial teams (Stewart \& Barrick, 2000), this has not been investigated empirically in research on TMT internal processes and emergent states.

Second, processes and emergent states have been studied in a timeless manner without reference to change, duration, concurrent and sequential effects, etc. This is not surprising given the methodological singularity that characterizes the field of TMT processes research: existing studies almost exclusively draw on survey research in a cross-sectional design with multiple regression as their method of analysis. However, the 'processual' and 'emergent' characters of these constructs have been largely ignored (e.g., Weingart, 1997).

Although the neglect of time is a more general issue in organizational research (Ancona, Goodman, Lawrence, \& Tushman, 2001; Roe, 2008), it is particularly problematic for future progress in the area of TMT processes and emergent states. As processes and states might have differential effects on outcomes dependent on the team's life stage, and temporal characteristics of processes and states, such as the duration, onset, or offset, might be related to outcomes, the neglect of these aspects has potentially contributed to inconsistent results and conclusions. Finally, the joint and recursive evolution of processes and emergent states over time is so far unknown. This is problematic for future progress in the area of TMT processes as it provides an over-simplistic account of the nature of TMT work and, thus, could lead to underspecified theoretical models. 


\section{Implications for Future Research}

This review suggests that TMT internal processes and states can explain organizational, TMT, and decision outcomes and are worth of study for team and upper-echelons researchers to gain insight in TMT impact on organizations. Furthermore, the often mentioned barriers to get access to TMTs for these types of measures seem to be surmountable. With these initial concerns established, we suggest that time has now come for a next generation of studies on TMT processes. In this section, we will provide some suggestions for future research.

\section{Better Understanding of the Role of TMT Structure}

TMTs are unique in the nature of their tasks of strategic decision making and implementation, which are characterized by often complex and unstructured streams of information and demands (Ancona, 1989; Cohen \& Bailey, 1997; Hambrick, 1994). TMTs are also unique in the sense that, despite being called a 'team', they sometimes seem to have little teamness to them (Hambrick, 1994). In this review, we showed that in many studies, the TMT was defined by the CEO, which leaves the question unanswered if these TMTs are real teams. Having a TMT as a 'real team' that is interdependent in its tasks might not always be the optimal choice for an organization, depending on, for example, the complexity of the environment in which the organization operates (Wageman et al., 2008). And TMTs that are not interdependent in their tasks, are not cohesive and do not communicate much can have the same positive effects as teams that are interdependent, and exhibit high levels of cohesion and communication (Barrick et al., 2007). But TMTs characterized by more mutual and collective interaction have been shown to achieve more desirable organizational outcomes (Carmeli \& Schaubroeck, 2006; Lubatkin et al., 2006) and organizations seem to increasingly rely on teams at the top (Wageman et al., 2008; Yukl, 2006).

Future research could profit from clarification of the nature of TMTs in terms of its structure the relatively stable pattern of relationships among team members that determine the allocation of tasks, responsibilities, and authority (Forsyth, 1999; Stewart \& Barrick, 2000). Moreover, large scale investigations on the relationship between TMT structure, processes and emergent states, and outcomes would be desirable. First, descriptive research is needed to analyze the structure, tasks, and functioning of TMTs in different types of organizations and environments. This could lead to insight in the extent to which, in practice, TMTs are real teams or not and in factors that shape the choice for one or the other structure. Then, the effects of processes and emergent states could be further investigated, possibly leading to different models of how TMT processes and emergent states contribute to outcomes in real-team TMTs versus co-acting ones. Team structure might then serve as a moderator for the effects of processes and states on outcomes (Barrick et al., 2007), or alternatively, as an input for processes and emergent states (Stewart \& Barrick, 2000). Finally, it would be interesting to investigate how environmental, organizational, and TMT characteristics interact to predict the circumstances in which real teams or co-acting groups make good performance more likely. 


\section{Incorporate Temporal Dimensions and New Methodologies}

A process, by definition, is something that 'happens' over time and which implies changes and developments in the interaction between TMT members (Weingart, 1997). The use of static measures to capture processes, which has been typical in the reviewed studies, is therefore not adequate and other methods will be needed to describe, for example, the onset, duration, and offset of conflict (Roe, 2005, 2008; Weingart, 1997).

Although the temporal dimension has occasionally been addressed in the research that we reviewed, studying TMT processes with a more explicit time focus would open several new research avenues (e.g., Ancona et al., 2001). For example, the relationship between TMT processes and TMT outcomes will be better understood when it is acknowledged that these relationships need not to be stable over time. Task conflict in the beginning of a decision-making process might have different consequences than task conflict in later phases of decision making (McGrath, Arrow, \& Berdahl, 2000; Weingart, 1997). Furthermore, a temporal approach allows distinguishing between stationary processes and emergent states, and provides a better conceptual base from which to analyze relationships between these variables over shorter and longer periods of time.

In general, researchers have pleaded for dynamic and recursive models within the upperechelons paradigm to address the option of reverse causality among variables of interest (Cannella \& Holcomb, 2005; Carpenter et al., 2004), but this need is even stronger for the study of TMT processes as these constructs are dynamic by nature. Despite the commonly known demands on TMTs' and researchers' time and energy to study TMT processes in longitudinal designs and possibly with high-density measures and diary methods, we contend that such efforts are necessary to advance future research. The 27 studies included in this review that studied TMT process are the proof that it is possible to study phenomena initially deemed almost impossible. For example, studying management teams on a business unit level (Bunderson, 2003; Bunderson \& Sutcliffe, 2003), cooperating with consultancy agencies (Wageman et al., 2008), or seeking the input from managers participating in executive education programs (Barsade et al., 2000), are all ways to reach a considerable number of TMTs with the possibility of gaining their trust and commitment.

As illustrated in table 2.1, current research on TMT processes is characterized by methodological singularity with an emphasis on survey research, cross-sectional designs, and multiple regressions as method of analysis. Various researchers have acknowledged this as a problem and have called for more fine-grained, qualitative, and longitudinal approaches to study TMT functioning (Cannella \& Holcomb, 2005; Carpenter et al., 2004; Pettigrew, 1992; Priem et al., 1999). It is only when more advanced approaches, involving longitudinal multi-level analysis, time-series analysis, or survival analysis, are used that researchers would be able to gain insight in what is really going on (Roe, 2008). Other promising methodologies include ethnographic studies of management teams in action (Samra-Fredericks, 2000), and the use of daily diaries with TMT members. Diaries allow researchers to study how people perceive events and how these can influence the internal dynamics on the individual and team level (Amabile, Barsade, Mueller, \& Staw, 2005; Amabile, Schatzel, Moneta, \& Kramer, 2004). 


\section{Investigate Relationships between Processes and Emergent States}

Future empirical research should also aim to unravel the interactions between task en relationship processes and emergent states. This is particularly important as these processes have been proposed to operate according to different mechanisms. The information-processing perspective (Haleblian \& Finkelstein, 1993; Hambrick \& Mason, 1984) emphasizes TMT task processes and the importance of differentiation in information, opinions, and arguments for TMT performance. On the other hand, TMT relationship processes should be more integrative in nature (Smith et al., 1994). This review supported arguments for both mechanisms. Task processes such as task conflict and debate were positively related to decision and organizational outcomes, but less so to TMT outcomes. Relationship conflict had negative effects on outcomes, whereas the emergent states of cohesion and social integration generally had positive effects. However, the resulting effects of the joint forces of these mechanisms are currently unclear.

As most studies have only incorporated one or a few processes and not examined their interrelations, at least not over time, it is not clear what the behavioral patterns of TMTs look like when they would combine all processes and emergent states that were found to be 'desirable'. Would different combinations of patterns of processes and states lead to similar outcomes? Could a 'task style' with high task conflict and low integration lead to similar results as a 'relationship style' with low task conflict and high integration? Team researchers, who perceive teams as complex and dynamic systems, have outlined conceptual models and proposed methodologies to study these patterns (Arrow et al., 2000; McGrath et al., 2000). They have reasoned that because of the multiple interactions between variables that are part of the complex system of teamwork, it is difficult to accurately predict at any given time the value of these variables. However, the joint patterns of key variables do show regularities over time; these patterns are then proposed to be influenced by contextual variables and to have consequences for team outcomes (McGrath et al., 2000). More research that focuses on TMT evolutionary patterns of joint processes and emergent states could provide interesting theoretical insight, while capturing the complex reality of TMT work.

\section{Conclusion}

As Hambrick (2007, p. 337) recently noted: "Our desire - our need - to open up the black box is not just a matter of scholarly curiosity; it is essential for ultimately improving the insights scholars can provide executives regarding how they might surmount or overcome the biases associated with their experiences and dispositions." This review aimed to do just so by providing a picture and assessment of what is and what is not known about TMT processes in that proverbial black box. Thereby, we have contributed to knowledge on the role of TMT internal processes in four distinct ways: 1) by providing a clear framework for organizing TMT research, 2) by providing an overview of what is known, 3) by indicating what is not yet known, and 4) by outlining suggestions for future research.

Our results show that scholars have important 'elementary' knowledge on the effects of processes and states on outcomes, but they also underline the importance of studying processes and emergent states more profoundly. However, as much of the research has relied on self-perceptions, quantitative analyses, and pre-existing concepts that were applied to a TMT setting for hypothesis 
testing, we feel that time has come for delving deeper in the box with a broader and more revealing set of methodologies. Insight in temporal dynamics of processes and in actual behavior that can complement TMT members' reports, define a way forward for researchers who want to understand how the things that happen in the boardroom can influence the value of teams at the top of organizations. 


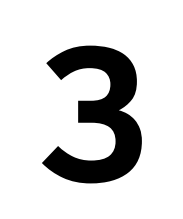

\section{Temporal Patterns of Conflict and Trust in Management Teams}

In this study, we analyze the evolution of two team internal processes (task and relationship conflict) and one team emergent state (trust). Using a longitudinal approach with five measurement moments over a period of ten months, we collected data on conflict and trust in 41 management teams of student associations. Our results show that discernable patterns of trust and conflict exist among teams. Half of the teams experienced a pattern of increasing conflict and decreasing trust, the other half of the teams showed a stable pattern of high trust and low conflict over time. Teams with the stable pattern were more effective than those with the unstable pattern. This study illustrates the necessity of studying team internal processes with a temporal perspective, which can benefit the fields of top management teams, as well as nonmanagerial teams.

This chapter is based on:

Raes, A. M. L., Heijltjes, M. G., \& Glunk, U. Exploring temporal patterns of trust and conflict in teams. Time in Organizational Research: Approaches and Methods (Eds. Roe, R. A, Waller, M. J., \& Clegg, S.). Routledge [forthcoming].

Raes, A. M. L., Heijltjes, M. G., Glunk, U., \& Roe, R. A. (2006). Conflict, trust, and effectiveness of teams performing complex tasks. METEOR Research Memorandum RM/06/008. 


\section{Introduction}

Researchers of top management teams (TMTs) are increasingly interested in the role of TMT internal processes and emergent states as determinants of TMT impact on organizations (Carpenter, Geletkanycz, \& Sanders, 2004; Peterson, Owens, Tetlock, Fan, \& Martorana, 1998; Smith et al., 1994; see also chapter 2 of this dissertation). For studying these processes and states, they often build on conceptual and theoretical work from the areas of social and organizational psychology, where the study of small groups and teams has since long been of interest (see Arrow, McGrath, \& Berdahl, 2000, for a historical overview). A recurrent issue of concern in both TMT and nonmanagerial team research is the lack of insight in the temporal nature of team behavior (Arrow et al., 2000; Carpenter et al., 2004; Certo, Lester, Dalton, \& Dalton, 2006; Ilgen, Hollenbeck, Johnson, $\&$ Jundt, 2005). In a recent review of team research it was concluded that: "Although the importance of [studying] dynamic conditions experienced over time is accepted by all, the empirical work is only beginning to consider the implications of time in research designs" (Ilgen et al., 2005, p. 536).

The lack of attention to temporal dynamics of team behavior is particularly surprising for those researchers interested in team processes and emergent states. Team processes describe the nature of team members' interaction and behavior while working on achieving the team's goals (Marks, Mathieu, \& Zaccaro, 2001). Team emergent states are the cognitive and affective states of teams that vary as a function of team context, inputs, processes, and outcomes (llgen et al., 2005; Marks et al., 2001). Two internal processes that researchers of TMTs and nonmanagerial teams have often studied are task and relationship conflict (De Dreu \& Weingart, 2003; Jehn, 1995; Simons \& Peterson, 2000), and they have studied team trust as an emergent state that is related to these processes (Dirks, 1999; Langfred, 2007; Simons \& Peterson, 2000).

Task conflict exists when team members disagree about the content of the task being performed, which includes differences in viewpoints, ideas, and opinions (Jehn, 1995). Relationship conflict, also named emotional (Barsade, Ward, Turner, \& Sonnenfeld, 2000), interpersonal (Knight et al., 1999), or affective (Amason, 1996; Amason \& Mooney, 1999; Amason \& Sapienza, 1997) conflict, occurs when interpersonal incompatibilities among team members exist, which typically include tension, animosity, and annoyance (Jehn, 1995). For trust, different conceptualizations have been proposed, but researchers among various disciplines share the view that it can be accurately described as: "a psychological state comprising the intention to accept vulnerability based upon positive expectations of the intention of the behavior of another" (Rousseau, Sitkin, Burt, \& Camerer, 1998, p. 395).

Despite an abundance of research on conflict and trust in TMTs and nonmanagerial teams (Costa, Roe, \& Taillieu, 2001; De Dreu \& Weingart, 2003; Simons \& Peterson, 2000), the temporal nature of conflict and trust is still relatively unexplored. Theories of team development suggest that conflict and trust can change over time as a result of shared experiences and increased familiarity among team members (Jones \& George, 1998; Tuckman, 1965; Tuckman \& Jensen, 1977), or by the experience of the time passed until a deadline for task completion (Gersick, 1988, 1989; Jehn \& Mannix, 2001). However, the implications of conflict and trust evolving over time periods of months or years for teams that do not work toward a specific project deadline are unclear. Researchers have 
suggested to focus on patterns of processes and emergent states instead of single variables to better understand their effects on team effectiveness (Arrow et al., 2000; McGrath, Arrow, \& Berdahl, 2000), but this has, to our knowledge, rarely been done.

The aims of this chapter are: 1 ) to provide insight in the evolution of task and relationship conflict and trust over a 10-month period in a sample of management teams ${ }^{1}$ of student associations, 2) to examine the existence of distinctive patterns of conflict and trust across teams, and 3 ) to relate patterns of conflict and trust to team effectiveness. In the following sections, we will outline our theoretical rationale and present hypotheses on the expected changes in conflict and trust over time, on joint evolutionary patterns of these variables, and on the impact of these patterns on team effectiveness.

\section{Theoretical Background}

\section{Conflict and Trust in Teams}

Task and relationship conflict have been the focus of many cross-sectional studies on team functioning (De Dreu \& Weingart, 2003; Simons \& Peterson, 2000). Researchers have studied, for example, how conflict can be triggered by diversity in team members' characteristics (Amason, 1996; Barsade et al., 2000; Pelled, Eisenhardt, \& Xin, 1999), how it is related to team effectiveness (De Dreu \& Weingart, 2003; Peterson \& Behfar, 2003), and on how it can be managed (Chen, Liu, \& Tjosvold, 2005). We focus in this chapter on the temporal nature of task and relationship conflict and on their effects on team effectiveness.

Relationship conflict is proposed to be negative for team effectiveness, because team members spend their time and energy on the conflict instead of the task, which limits the information processing ability of team members and distracts time and energy from completing team tasks (Jehn \& Mannix, 2001). It also limits team members' cognitive functioning by increasing their stress and anxiety levels. Furthermore, negative attributions of team members' behaviors can create selffulfilling prophecies and lead to conflict escalation (Simons \& Peterson, 2000). Empirical findings regarding the negative effects of relationship conflict on team performance and team member satisfaction are strong and widely established (De Dreu \& Weingart, 2003).

Task conflict is frequently proposed to be beneficial for team effectiveness, especially for teams that perform complex tasks (Amason, 1996; Jehn, 1995; Olson, Parayitam, \& Bao, 2007). Within an information-processing perspective, researchers have reasoned that team effectiveness will benefit from task conflict, as this type of conflict increases the amount and variety of information that is incorporated in team interaction which is supposed to lead to better and more innovative decisions (Amason, 1996; West \& Anderson, 1996). However, when conflict becomes too high, team

\footnotetext{
${ }^{1}$ These management teams can be characterized as TMTs, as they are, for their student associations, "the aggregate informational and decisional entity through which the organization operates and which forms the inner circle of executives who collectively formulate, articulate, and execute the strategic and tactical moves of the organization" (Eisenhardt, Kahwajy, \& Bourgeois, 1997; Klenke, 2003). However, noticing that the term 'TMT' is usually reserved for those teams of executives at the top of large business organizations and realizing that the teams in our sample can only to a limited extent be compared to such TMTs, we will in this chapter simply refer to them as 'teams'. The method section of this chapter describes the nature and tasks of the teams in our sample in more detail.
} 
members' cognitive load increases, which limits cognitive resources for taskwork. Hence, team effectiveness is likely to suffer (De Dreu \& Beersma, 2005; De Dreu \& Weingart, 2003). Since we focus on teams with complex tasks, we expect task conflict to be beneficial for effectiveness, provided that it is moderate and does not extend into relationship conflict (Olson et al., 2007).

Trust has been proposed as an important element of interpersonal relationships in general (Mayer, Davis, \& Schoorman, 1995; McAllister, 1995) and team dynamics in particular (Costa et al., 2001; Langfred, 2004). Teams with high levels of trust, as compared to teams with low levels of trust, exchange ideas more openly, search more extensively for alternative courses of action and have greater motivation to implement decisions (Zand, 1972). Deficits of trust in teams have been associated with high stress, low satisfaction, and low task performance for team members (Costa et al., 2001). With respect to trust and team effectiveness, research suggests that trust is positively related to various measures of team effectiveness (Costa et al., 2001; Peterson \& Behfar, 2003). Other researchers have proposed that the mechanisms by which trust influences team outcomes are probably indirect rather than direct, for example, via its influence on conflict, reflexivity, or monitoring behavior (De Jong, 2007; Dirks, 1999; Langfred, 2004).

Task and relationship conflict and trust are not independent. In two recent reviews, correlations between task and relationship conflict from .18 to .88 were reported (De Dreu \& Weingart, 2003; Simons \& Peterson, 2000) and in a recent study, the constructs could not even be empirically distinguished from each other (Van der Vegt \& Bunderson, 2005). Furthermore, trust has been found to be negatively related to relationship conflict (Langfred, 2007; Peterson \& Behfar, 2003; Simons \& Peterson, 2000), and both positively (Olson et al., 2007) and negatively (Peterson \& Behfar, 2003; Simons \& Peterson, 2000) to task conflict. Trust can also moderate the relationship between task and relationship conflict, such that the correlation between task and relationship conflict is higher when intra-team trust is low (Simons \& Peterson, 2000).

Despite the centrality of the constructs of conflict and trust for researchers studying team interaction and effectiveness, not much is known about changes or stability of conflict and trust over extended periods of time, and on how they dynamically influence each other. In the following paragraphs, we will pay attention to the temporal nature of these constructs from various theoretical perspectives, and analyze the few studies that did study trust and conflict over time (Jehn \& Mannix, 2001; Peterson \& Behfar, 2003).

\section{Models of Team Development}

Early psychological research has focused on changes in groups over time and scholars have proposed that aspects of group functioning, such as its task approach or group members' interpersonal relationships, are not stable over time (Bales, 1950; Tuckman, 1965; Tuckman \& Jensen, 1977). In these models, increased familiarity of team members with each other and their task is proposed to produce changes in individual- and team-level processes and outcomes. Thus, with the definition of time as "a nonspatial continuum in which events occur in apparently irreversible succession from the past through the present to the future" (Ancona, Okhuysen, \& Perlow, 2001, p. 513), time provides a dimension to organize team events and experiences. These events and 
experiences induce changes in team processes and emergent states, and can thus be seen as the 'motors' of change (e.g., Van de Ven \& Poole, 1995).

Although events and experiences vary among teams, classical models of team development assume that there is a certain predictable pattern of development that characterizes all teams. Among these models, Tuckman's stage model is currently still the most well known and often used by scholars and practitioners alike (Chang, Bordia, \& Duck, 2003; Tuckman, 1965; Tuckman \& Jensen, 1977). In this model, it is proposed that teams go through stages of 'forming', 'storming', 'norming' and 'performing' during their life time. According to Tuckman, after the initial forming stage in which members become familiar with each other, teams enter a storming stage, during which disagreements over procedures and tensions arise between team members. Subsequently, teams go trough a stage of norming in which cohesion grows, roles are established, and trust increases. Finally, during the performing stage, teams establish a high task orientation and an emphasis on performance (Tuckman, 1965; Tuckman \& Jensen, 1977). Although this model does not make specific predictions regarding conflict and trust, the proposed development of teams through the stages seems to imply that trust will increase over time, that relationship conflict will first increase and then decrease, and that task conflict will increase over time ${ }^{2}$.

Whereas early researchers of group development have focused on broad patterns of both task and relational aspects of team interaction, subsequent work has specifically addressed the dynamics of task behavior for teams. Specifically, Gersick's punctuated equilibrium theory (Gersick, 1988, 1989, 1991) proposes that teams' awareness of the time left until the end of a project leads to a sudden shift in its task approach, usually about halfway through the team's allotted time. Teams that were aware of being halfway through their time and used this 'midpoint transition' to make a qualitative shift in their task approach, were more successful than teams were also aware of the midpoint, but did not make a transition.

Conflict evolution. Some evidence for how punctuated equilibrium theory could predict conflict evolution in teams comes from a study investigating task, process, and relationship conflict levels of high and low performing student task groups during three time blocks over a 3-month period (Jehn \& Mannix, 2001). High performing teams followed a pattern in which Gersick's 'midpoint transition' could be clearly distinguished: an increase in task conflict during the middle time block was followed by a decline in task conflict during the last time block. Relationship conflict was low, but rose significantly during the last time block. Low performing groups did not experience such a midpoint transition, but instead experienced a large increase in task and relationship conflict toward the end.

The results of this study are intriguing and the authors clearly demonstrate that conflict must be examined as a dynamic process, rather than a static event (Jehn \& Mannix, 2001). One question that emerges from their study, however, is to what extent the results on the evolution of conflict are context specific. Participants in the study were students that worked in task groups during a course: teams that were put together to complete specific tasks in a limited, pre-defined period of time. When translating these results to teams that perform complex tasks over longer periods of time and

\footnotetext{
2 This is under the assumption that task conflict is beneficial for team effectiveness. As Tuckman's model predicts that teams will become increasingly effective over time, given the management tasks of the teams in our sample, increased task conflict should be one of the drivers of this increase in team effectiveness.
} 
without a specific deadline associated with the completion of the task, a number of characteristics of the conflict pattern as found by Jehn and Mannix might disappear. The midpoint transition, which is triggered by the awareness of the time remaining before a deadline (Gersick, 1988, 1989), might be less obvious in these situations and the increases in task and relationship conflict towards the specific deadline might not occur.

Trust evolution. Other theoretical work has specifically focused on the evolution of trust (Jones \& George, 1998; Lewicki, Tomlinson, \& Gillespie, 2006). In Jones and George's (1998) model, trust can evolve through three different states: conditional trust, unconditional trust, and distrust. In each state of trust, teamwork is affected in a different way. When conditional trust is present, team members are willing to interact with each other as long as their behavioral expectations are met. They are, in other words, continually testing each other's trustworthiness. When unconditional trust exists, the trustworthiness of the other party is assumed and confidence in the other's values exists. A critical assumption of this model is that team members will initially trust each other. Or, in Jones and George's words, "at the beginning of a social encounter, people suspend belief that the other is not trustworthy" (p. 535). Adopting an initial assumption of trust is the preferred option for team members, because it is more efficient in terms of cognitive demands than initial distrust. Furthermore, in organizational settings, institutional cues will often enable team members to trust each other without other first-hand knowledge (McKnight, Cummings, \& Chervany, 1998). In this initial phase, trust experiences are in a state of conditional trust.

Over time, three possibilities exist: conditional trust evolves into unconditional trust, conditional trust evolves into distrust, or conditional trust remains in place. Conditional trust can develop into unconditional trust when the experiences of team members remain positive, while conditional trust ends in distrust when positive expectations are not reciprocated (Jones \& George, 1998). Thus, based on this model, we would expect two different possibilities for trust evolution in teams. First, when conditional trust is not reciprocated and evolves toward distrust, trust levels will spiral downward. Such a hypothesis of a downward spiral has also been proposed, but not tested, by Zand (1972). Second, when conditional trust evolves into unconditional trust, we would expect an upward spiral. Although the authors are not explicit on what a transition from conditional to unconditional trust implies in terms of the level of trust, it seems likely that unconditional trust is a 'deeper' form of trust, as it is based on perceived shared values (Jones \& George, 1998). A third option is that conditional trust stays in place for the whole period of team functioning. However, as noted by Jones and George (1998), conditional trust is unlikely to promote the high involvement of people with their work and their team that is a prerequisite of successful teamwork. Thus, a permanent state of conditional trust is highly unlikely for teams that collaborate intensively for a prolonged period of time.

\section{Hypotheses}

For the evolution of conflict and trust, both Jones and George's (1998) and Tuckman's (1965) models imply that they develop as a result of team members' evaluations of repeated behavioral encounters with fellow team members, which we previously described as the 'motor' of trust (Van de Ven \& 
Poole, 1995). This is also in line with Wilson and colleagues' (2006) recent reasoning that when teams are together longer, increased social information exchange will result in increased trust. Gersick's (1988, 1989) punctuated equilibrium theory suggests that changes in processes can also be triggered by experiences related to taskwork and that qualitative changes in team processes and states occur at certain predictable moments related to the task work of the team.

According to Tuckman, these social experiences should lead to increasing levels of trust and decreasing levels of relationship conflict and these changes occur gradually over time - at least in groups that function well. Furthermore, as task conflict is proposed to be beneficial for team effectiveness and teams are proposed to become more effective over time, application of Tuckman's model would imply that task conflict should also increase over time. Gersick's punctuated equilibrium theory would suggest that changes in teams do not occur gradually, but rather at certain moments in a team's life and are preceded and followed by periods of inertia. Qualitative changes can be particularly expected to occur at the moment when teams realize that they have passed about half of their time. A recent integration of Gersick's model with a stage model of team development, such as Tuckman's, showed that a midpoint transition is most likely for task-related processes, whereas gradual changes are most likely for socio-emotional processes and states (Chang et al., 2003).

Therefore, we suggest that task conflict follows the evolutionary pattern of punctuated equilibrium theory with an increase in task conflict in the middle of team functioning, a pattern that was also found by Jehn and Mannix (2001). Since the teams in our sample worked on multiple complex tasks simultaneously while existing for a fixed 1 -year period, we did not expect that a team's midpoint transition would be tied to one specific task, but rather to the total time that the team existed. As relationship conflict is an aspect of socio-emotional team dynamics, we expected that relationship conflict changes gradually as predicted by Tuckman's stage model, which is in line with the reasoning of Chang and colleagues (2003). Although relationship conflict can be expected to slightly increase in the beginning of teamwork, indicating a storming phase, we expect an overall pattern of decreasing relationship conflict, as teams will tend to develop productive working relationships over time. Also in line with Tuckman's model, we expect that trust will increase over time. As team members build trust in each other based on repeated behavioral encounters, we expect that this increase is gradual rather than sudden. In Jones and George's terminology, this implies that we expect most teams to make the transition from conditional to unconditional trust and we assume that this is visible in an increase of the average trust level over time. Hence, we hypothesize:

Hypothesis 1a. Team relationship conflict will gradually decrease over time.

Hypothesis $1 b$. Team task conflict will increase at the midpoint of team functioning and then decrease, and it will be stable across all other times.

Hypothesis 1c. Team trust will gradually increase over time. 


\section{Patterns of Conflict and Trust and their Relationship to Team Effectiveness}

In order to capture the complex dynamics of organizational teams over time, it has been argued that researchers should go beyond the effects of single variables and examine patterns of development (Arrow et al., 2000; McGrath et al., 2000). This way, the joint effects of processes and emergent states on team effectiveness could be better understood. Since task conflict, relationship conflict and trust have been shown to be related to each other in cross-sectional research (De Dreu \& Weingart, 2003; Simons \& Peterson, 2000) and since the proposed effects of task and relationship conflict on team effectiveness are contradictory, this call seems to be particularly applicable for understanding the effects of these variables on team effectiveness. Therefore, we want to examine the pattern of joint evolution of conflict and trust for understanding their effects on team effectiveness.

A positive association exists between task and relationship conflict, because task related disagreements can be misinterpreted as personal attacks (De Dreu \& Weingart, 2003; Simons \& Peterson, 2000). Trust can play an important role in moderating this relationship. In teams with high trust, team members are less likely to misattribute task as relationship conflict, but if team members distrust each other, disagreements with others on the tasks are easily interpreted in a negative personalized manner (Simons \& Peterson, 2000). Both task and relationship conflict have been shown to be negatively related to trust, with the correlations for trust and relationship conflict being somewhat stronger than those for trust and task conflict (Peterson \& Behfar, 2003; Simons \& Peterson, 2000).

Although covariance in cross-sectional research does not necessarily imply a relationship over time, some evidence of these relationships has also been found in a longitudinal context (Langfred, 2007; Peterson \& Behfar, 2003). In the study of Peterson and Befahr (2003), the dynamic relationship between conflict and performance was demonstrated in a setting where task and relationship conflict were evoked by performance feedback. The authors show that a high level of trust helps to prevent the development of relationship conflict (Peterson \& Behfar, 2003). On the other hand, Langfred (2007) showed that existing relationship conflict decreased trust later on. When the relationships between conflict and trust as have been found in previous research persist over time, a steady increase in conflict and a decrease in trust over time may be the result. This pattern could also be described as a deviation-amplifying loop in which a change in one variable - an increase in task conflict - leads to changes in other variables - increase in relationship conflict and decrease in trust, - which, in turn, continues to amplify (Lindsley, Brass, \& Thomas, 1995). The existence of an amplifying loop makes it difficult to determine cause and effect (Weick, 1979); conflict and trust both act as causes and as effects.

Following Jones and George (1998), we assume that teams start with a certain level of conditional trust which is necessary to begin functioning as a team. During the early stages of a team's life, by shaping the attitudes, moods and emotions toward the other party, team members create mutual perceptions of trustworthiness (Jones \& George, 1998). This perceived trustworthiness can then evolve in two different ways; either trust remains to exist or trust gradually disappears. When perceived trustworthiness among team members is high, it becomes unlikely that task conflict will be perceived as a personal attack rather than as a difference in opinion about the task at hand. 
This implies that the process of misattribution (Amason, 1996; Jehn \& Mannix, 2001; Simons \& Peterson, 2000) is less likely to occur and that the start of a deviation-amplifying loop is prevented (Lindsley et al., 1995). In a way, the high level of trust makes sure that the level of task and relationship conflict remains contained within certain margins (Peterson \& Behfar, 2003). As a result, this pattern will evolve in a relatively stable manner over time.

A very different pattern will occur when trust fails to develop within a team and exchanges between team members lead to decreasing perceptions of trustworthiness. In this case, trust will not be able to prevent misattribution. A discussion on task-related issues will be more easily misperceived as a personal conflict, resulting in negative emotions among team members. As time progresses, a deviation-amplifying loop may be triggered, in which task conflict leads to relationship conflict, which in turn increases task conflict, which increases relationship conflict etc. In this case, increasing levels of relationship and task conflict over time will further deteriorate the perceptions that team members have of each others' trustworthiness, leading to a further decline in trust.

Although the actual development of conflict and trust over time may take different forms, we expect that the two types of developments as described here will prevail. The covariance of task conflict, relationship conflict, and trust over time will be referred to as 'pattern'. We thus assume that the patterns differ in the levels of task conflict, relationship conflict, and trust, in the evolution of these constructs, and in their correlations over time. Thus, we hypothesize:

Hypothesis 2. Two types of patterns of task conflict, relationship conflict, and trust can be distinguished across teams. The first is an unstable, deteriorating pattern, characterized by low levels of trust and high and increasing levels of task and relationship conflict that are strongly correlated. The second pattern is a stable pattern characterized by stable levels of high trust and moderate task and relationship conflict, in which the variables are weakly correlated.

With regard to the effects of task conflict, relationship conflict, and trust on team effectiveness, the negative effect of relationship conflict has been established most clearly, while empirical results for the expected positive effects of task conflict and trust are less consistent (De Dreu \& Weingart, 2003; De Jong, 2007; Langfred, 2004). Therefore, we expect that relationship conflict will be the primary mechanism through which the patterns of conflict and trust exert their effects on team effectiveness. When high trust prevents the misattribution of task conflict as relationship conflict, a double beneficial effect occurs for team effectiveness: trust inhibits relationship conflict and stimulates task conflict - assuming that the conditions for promoting task conflict, such as team members' cognitive diversity (Pelled et al., 1999), are present and do not systematically vary across teams. Therefore, we expect that teams with the stable pattern of conflict and trust, in which early high levels of trust contain the association between task and relationship conflict within certain margins, are more effective than teams in which low levels of trust allow correlations between task and relationship conflict to increase in an upward spiral. Thus, we formulate the following hypothesis: 
Hypothesis 3. Teams that over time show a high level of trust and a moderate level of task and relationship conflict (and thus operate in a stable pattern) are more effective than teams that over time show a low level of trust and increasing levels of task and relationship conflict (and thus operate in an unstable, deteriorating pattern).

\section{Method}

\section{Sample and Procedures}

We tested our hypotheses in a sample of 41 management teams (271 individuals) at five moments in time during a 10-month period. These teams were the executive boards of 41 large student associations scattered across twelve cities in the Netherlands. These associations consist solely of students, and their organizational goal is to provide academic-, network-, and leisurerelated activities to its members. The team members of the board have a full-time job and joint responsibility for managing the student association and are paid by university funds. The nature of the tasks the teams perform is complex, interdependent, and resembles, to a certain extent, those of top management teams of business organizations. It includes strategic and operational decision making and maintaining relationships to many different stakeholders, such as the members of the association, the university, commercial sponsors, and municipal and federal government. Furthermore, since the teams are positioned at the top of their organization, they also have a symbolic value for their stakeholders.

All teams commenced in September, at the start of the academic year, and worked together for one year during which team composition remained stable. Team members work together intensively, often working all together in one room for at least eight hours per day, and usually more, as the associations' main activities for the students take place during evenings. The primary advantages of this sample of teams were the availability of a relatively large cohort of teams starting at the same time with a stable composition over a year, and the fact that these teams - although they consisted of students - operated in real organizations with real responsibilities. The tasks of the individual team members within the teams were comparable across teams and usually organized along traditional team functions, such as chairperson, vice-chairperson, treasurer, coordinator intraorganizational affairs, coordinator external affairs, etc.

To frame the sample, websites of all universities and student related institutions in the Netherlands were searched for references to student organizations, which resulted in a sample of about 90 associations. Since task type moderates the relationship between team conflict and team effectiveness (Stewart \& Barrick, 2000), we wanted to ensure that the tasks of the teams in our sample were comparable. Therefore, the teams had to meet two criteria to be included: 'team members have a fulltime job in fulfilling the team's tasks' and 'the student association has to count at least 200 members.' Using these criteria, 55 teams were approached with a written request for participation in the study and 43 teams confirmed their participation, a response rate of $80 \%$.

As in most longitudinal studies, not all teams provided complete information for all measurement moments and we removed two teams from the sample for which we did not have complete data. This has led to a final sample of 41 teams. This sample comprised 271 team members, 
$57 \%$ of whom were male, and $98 \%$ of whom had the Dutch nationality. The mean age of respondents was 23 years with a standard deviation of 1.4 , and the majority of them (78\%) has been a member of the student association between 3 and 4 years. The average team-size was 6.6 persons.

Data collection, which also included other variables not reported in this chapter, took place during six measurement moments within a period of ten months during one academic year. Measurement moments were spread evenly over time, roughly with a 6- to 8-week time-lag, at time 1 (October 4-16), time 2 (November 22 to December 3), time 3 (January 10 to 21), time 4 (February 24 to March 11), time 5 (April 25 to May 6), and time 6 (June 20 to July 1). As no generally established guidelines exist for choosing the length of time intervals in longitudinal research (Roe, 2005), and since virtually no research has investigated the length of the time lags needed to detect changes in team processes and states over longer time periods (the most informative exception was Jehn \& Mannix, 2001), we decided to take as many measurement moments as possible and capture possible changes as fine-grained as we could, while still ensuring the cooperation of the team members and maintaining realistic data-gathering demands for the researchers.

In order to ensure $100 \%$ team-level response rates over the whole year, five researchers made personal data collection visits to every team at every measurement moment ${ }^{3}$. During these visits, scheduled when all team members were present, the researchers asked the team members to complete a questionnaire, after which these were collected by the researcher immediately. Occasionally, when a team member was absent, a response envelope was left behind that had to be returned as soon as possible. This data collection strategy proved to be fruitful: it resulted in a data set in which all team members of every team completed the questionnaire at every measurement moment. Because of the longitudinal nature of the study, questionnaires needed to be coded in order to trace every individual back to a previous measurement moment, as well as to the team; however, we assured respondents that their answers would be used confidentially. To thank the teams for their cooperation, as well as to make the research more interesting to participate in, we promised and delivered a feedback report for each team. In this report, only team-level data were reported in order to ensure anonymity of respondents' answers to their fellow team members.

\section{Measures}

At time 1, shortly after the commencement of the team, information on team composition variables was obtained that was not analyzed further for this chapter (but see Van Olffen, Raes, Blumberg, \& Chung, 2007). Conflict and trust were measured at time 2, 3, 4, 5, and 6, along with other team processes not analyzed in this chapter. Team effectiveness was measured at time 6 . Unless indicated otherwise, all items for all variables in the study had to be answered on a 5-point Likert scale with scale anchors $1=$ totally disagree and $5=$ totally agree.

Relationship conflict. We measured relationship conflict with Jehn's (1995) scale for this construct with four items. Items were translated into Dutch and adapted to the longitudinal research design of the study. A typical item is 'During the past six weeks, people often got angry while working

\footnotetext{
${ }^{3}$ This explains why every round of data collection took about two weeks, as data collectors were traveling through the Netherlands. 
in our group.' Cronbach's alpha's for the scales across the measurement moments were .82 at time 2, .79 at time $3, .83$ at time $4, .85$ at time 5 , and .85 at time $6 .^{4}$

Task conflict. This type of conflict was measured by Jehn's (1995) task conflict scale, consisting of three items. Items were translated into Dutch and adapted to the longitudinal research design. A typical item is 'During the past six weeks, people often had conflicts of ideas.' Cronbach's alpha's were .56 at time 2, .58 at time 3,.65 at time 4,.68 at time 5, and .71 at time 6. Alpha levels for task conflict are generally lower than those for relationship conflict (Jehn, 1995; Pelled et al., 1999; Simons \& Peterson, 2000), however, the values we found in this study, except for time 6, were relatively low as compared to those in other studies and below the generally accepted level of .70 (Nunnally, 1978). As the alpha levels were steadily increasing across subsequent measurement moments, it seems that in our sample, task conflict was something that team members could not clearly relate to immediately from the beginning on, but that did become a more established phenomenon over time.

Because of these relatively low alpha levels, and because one previous study had indicated that task and relationship conflict are sometimes better represented as a single factor (Van der Vegt \& Bunderson, 2005), we assessed the dimensionality of conflict in our study using confirmatory factor analysis. Using Lisrel version 8.72, we performed multi-group confirmatory factor analyses for the individual level data on the task and relationship conflict items at the five measurement moments and we compared a 1- to a 2-factor model of conflict. Examining the fit indexes of both models, we saw a better fit for the 2 -factor $\left(\chi^{2}\left(65, N_{\text {mean }}=267\right)=159.51, p<0.00, \mathrm{RMSEA}=0.07, \mathrm{NNFI}=0.97\right)$ than for the 1 -factor model $\left(\chi^{2}\left(70, N_{\text {mean }}=267\right)=383.27, p<0.00\right.$, RMSEA $=0.13, \mathrm{NNFI}=0.91 ; \Delta \chi^{2}(\Delta d f)$ $\left.=223.76_{(5)}, p<0.00\right)$. Therefore, despite the relatively low alpha levels for task conflict, but in line with the theoretical rationale and the majority of previous studies, we proceeded by treating task and relationship conflict as separate constructs.

Trust. In line with our theoretical definition of trust and previous empirical work (Dirks, 1999; Wilson et al., 2006), we view trust as fundamentally interpersonal in nature. Although researchers have also used the team-as-whole as the entity in which trust resides (Langfred, 2004; Simons \& Peterson, 2000), we adopted an approach in which trust is directed toward individual team members, as even within the social entity of a team, team members may vary in the extent to which they trust one or the other team member and such variations might blur a measure for trust in the team as a whole. Therefore, trust was measured by asking respondents to estimate on a 7-point Likert scale, anchored by 1 = very little and 7 = very much, for each of their fellow team members to what extent they could trust them, presenting the respondents with a definition that reflected trustworthiness (Costa et al., 2001; McAllister, 1995). The definition was: 'Trust is the extent to which you feel you can count on another person in situations in which this is important to you'. This way, each team member received multiple trust scores. These scores were averaged per team member to obtain one 'trust score' per team member and then aggregated to the team level by taking the average of the trust scores of all team members. Thus, in our study, trust as an emergent state on the team level represents the average trust present in all one-to-one relationships of team members to each other.

${ }^{4}$ All Cronbach's alpha's are based on the individual level data. 
Team effectiveness - self perception. This variable was measured by seven items that were based on the measure of team effectiveness of Flood and colleagues (2000). We translated these items into Dutch and adapted them to the longitudinal context of the research and the specific sample. For example, the item 'Our company goals are clear in the minds of every member of the top management group' was transformed into 'The goals of this association were clear for every member of the management team'. Cronbach's alpha for this scale was 0.81 .

Team effectiveness - stakeholder measure. To avoid common-source bias due to the fact that both dependent and independent measures were self-perceptual, we also included an external measure to assess the effectiveness of the management teams (e.g., Podsakoff, MacKenzie, Lee, \& Podsakoff, 2003). For constructing this measure, we used Hackman's $(1987,2002)$ first criterion of team effectiveness that the "productive output of the team (that is, its product, service, or decision) meets or exceeds the standards of quantity, quality, and timeliness of the team's clients-the people who receive, review, or use the output" (Hackman, 2002, p. 23). The main 'clients' of these management teams - as indicated by the team members themselves in response to an open question in our questionnaire at time 2 - were the members of their student associations. Therefore, we approached the members of the student associations from the participating teams to indicate how effective they considered their management team to be.

Questionnaire development for this stakeholder measure of team effectiveness was guided by answers to an open question at time 2, asking team members to 'describe how one can see how effective the management team is'. Via an open coding procedure involving the first author and two research assistants, elements of team effectiveness that were relevant to the members of the student associations were identified and used as the base for formulating questionnaire items. A pilot study of this questionnaire among ten students, but not part of the target organizations, led to some revisions of the questions. A sample item for this dimension of team effectiveness is 'the management team does contribute to the design of new activities' and 'the management team reached its goals'. In the appendix on page 84 , the complete version of the questionnaire for the members of the students association is presented.

Although all teams were approached for participation in this stakeholder measure of team effectiveness, the final sample consisted of the members of 28 student associations only. Multivariate analysis revealed no significant differences on the research variables between the teams from associations that did versus those that did not participate in the stakeholder measure. In total, the sample comprised 2218 members. The number of respondents per association varied between 20 and 168 with a mean of 79 respondents. The mean response rate per association was $19 \%$ of the members, and response rates varied between $6 \%$ and $35 \%$. Cronbach's alpha for this scale was 0.95 . An exploratory factor analysis showed that one factor accounted for $46 \%$ of the variance and therefore, we used an unweighted mean of the item scores as our measure of effectiveness.

Data aggregation. Since the unit of data collection in this study was the individual, while the unit of theory and analysis was the team, individual data had to be aggregated to the team level for further analysis. That is, we assumed that team members' perceptions of task conflict, relationship conflict, and team effectiveness were indicators for the corresponding team level phenomena (e.g., Hofmann, 2004). The value of $R_{w g}$ is often proposed as an indicator for within-group agreement, the 
extent to which ratings from individual team members are interchangeable (Bliese, 2000; George, 1990; James, Demaree, \& Wolf, 1984). High within-team agreement would indicate that we have indeed observed team-level phenomena. A minimum value of .70 is generally accepted as an indicator that the phenomenon can be represented as a team level variable (George, 1990).

The mean $\mathrm{R}_{\mathrm{wg}}$ over all teams and time moments for relationship conflict was .87, for task conflict .88, for self-perceived team effectiveness .80, and for the stakeholder perception of team effectiveness .90, indicating good within-team agreement for all variables. Thus, we used the mean of the scores of the items as our measures for these constructs at the team level. The data on trust are individual-on-individual data. Since the assessments of individual members about a focal member were not considered to be parallel measures of the same construct, no specific aggregation method, other than averaging to the team level, was used.

\section{Data Analysis}

To examine hypothesis $1 \mathrm{a}, 1 \mathrm{~b}$, and $1 \mathrm{c}$, we conducted repeated measures multivariate analysis of variance (MANOVA) on relationship conflict, task conflict, and trust with time moment as independent variable.

To test if some teams would exhibit an unstable and deteriorating pattern and others a stable pattern (hypothesis 2), we had to classify the teams according to their scores on conflict and trust on the five measurement moments. This way, we would be able to see if discernable patterns of these variables existed across teams. Toward this aim, a cluster analysis was performed. Cluster analysis is a technique frequently employed to search for groups in data, using measures of similarity (or dissimilarity) to determine membership either within a given group or across different groups (Hair, Anderson, Tatham, \& Black, 1995). As demonstrated by Russell (2001), using a cluster analysis is also appropriate to detect groups that are characterized by similar patterns over time. The teams that made up the clusters were then analyzed with regard to the level, evolution, and correlations of task conflict, relationship conflict, and trust.

To test if the patterns were associated with differences in team effectiveness (hypothesis 3), we performed two univariate analyses of variance (ANOVA) with cluster membership as independent and the two measures of team effectiveness as dependent variables. Separate univariate were performed instead of one multivariate analysis, because the sample sizes for the two measures differed considerably (41 versus 28 teams).

\section{Results}

\section{Descriptives}

Table 3.1 presents the means, standard deviations, $R_{w g}$ 's, Cronbach's alpha's, and correlations between all variables in the study. These results show that task conflict, relationship conflict, and trust were generally strongly correlated, also over multiple measurement moments. Autocorrelations of trust across different moments were slightly stronger than those of task and relationship conflict. Relationship conflict was strongly negatively correlated to both measures of 
team effectiveness, task conflict was less strongly, and also negatively correlated to team effectiveness, whereas trust was strongly and positively correlated to both team effectiveness measures. The self-perception and the stakeholder perception measures of team effectiveness were strongly and positively correlated to each other $\left(R^{2}=.65\right)$.

\section{Changes in Conflict and Trust over Time}

To test for longitudinal changes in task conflict, relationship conflict, and trust in the total sample, we performed repeated measures MANOVAs for these variables across measurement moments. Results showed a significant multivariate time effect for relationship conflict $\left(F_{(4,37)}=4.30\right.$, $p<0.01)$ and trust $\left(F_{(4,37)}=5.34, p<0.00\right)^{5}$, but not for task conflict $\left(F_{(4,37)}=0.44, p=\right.$ n. s. $)$. Thus, hypothesis $1 \mathrm{~b}$, stating that task conflict would increase and then decrease over time, was not supported.

An examination of the mean levels of relationship conflict across the measurement moments showed that relationship conflict increased over time from $2.08(S D=.41)$ at time 2 to $2.34(S D=$ .45 ) at time 6 . Inspection of the contrasts showed that only the difference between time 3 and time 4 was significant. Thus, relationship conflict at time 2 and 3 was significantly lower than relationship conflict at time 4, 5, and 6 . Thereby, hypothesis 1 a, stating that relationship conflict would gradually decrease over time is not supported. On the contrary, relationship conflict increased instead of decreased and this change was not gradual, but occurred at the midpoint of team functioning.

Inspection of the mean levels of trust across the measurement moments showed that trust decreased over time (Time 2: $M=5.59, S D=.34$; Time $6: M=5.43, S D=.45$ ). This was contrary to our expectations that trust would increase as a result of increased familiarity and social exchange among team members. Inspection of the contrasts showed that, again, the significant decrease in trust occurred between time 3 and time 4, whereas none of the other differences between the measurement moments was significant. Thus, hypothesis $1 \mathrm{c}$ is not supported, as trust decreased rather than increased. As was the case with relationship conflict, this decrease was observed as a sharp decrease at the midpoint of team functioning, and not as a gradual change over time.

\footnotetext{
${ }^{5}$ The reported F-values are the values of Pillai's Trace indicator. Examination of the other multivariate statistics (Wilk's Lambda, Hotelling's Trace, and Roy's Largest Root) did lead to different results. 
Table 3.1. Means, standard deviations, $R_{w g}$ 's, Cronbach's alpha's, and correlations of the variables in the study

\begin{tabular}{|c|c|c|c|c|c|c|c|c|c|c|c|c|c|c|c|c|c|c|c|c|}
\hline & $M$ & $S D$ & $R_{w g}$ & 1 & 2 & 3 & 4 & 5 & 6 & 7 & 8 & 9 & 10 & 11 & 12 & 13 & 14 & 15 & 16 & 17 \\
\hline \multicolumn{21}{|l|}{ Time 2} \\
\hline 1. Relationship conflict & 2.08 & .41 & .86 & .82 & & & & & & & & & & & & & & & & \\
\hline 2. Task conflict & 2.61 & .33 & .90 & .45 & .56 & & & & & & & & & & & & & & & \\
\hline 3. Trust & 5.59 & .34 & n.a. & -.60 & -.32 & n.a. & & & & & & & & & & & & & & \\
\hline \multicolumn{21}{|l|}{ Time 3} \\
\hline 4. Relationship conflict & 2.16 & .41 & .88 & .56 & .49 & -.52 & .79 & & & & & & & & & & & & & \\
\hline 5. Task conflict & 2.59 & .33 & .85 & .51 & .71 & -.38 & .73 & .58 & & & & & & & & & & & & \\
\hline 6. Trust & 5.62 & .40 & n.a. & -.42 & -.22 & .77 & -.58 & -.46 & n.a. & & & & & & & & & & & \\
\hline \multicolumn{21}{|l|}{ Time 4} \\
\hline 7. Relationship conflict & 2.35 & .44 & .87 & .25 & .39 & -.19 & .61 & .62 & -.27 & .83 & & & & & & & & & & \\
\hline 8. Task conflict & 2.61 & .37 & .89 & .26 & .62 & -.23 & .59 & .68 & -.30 & .58 & .65 & & & & & & & & & \\
\hline 9. Trust & 5.45 & .38 & n.a. & -.30 & -.18 & .64 & -.52 & -.44 & .74 & -.46 & -.41 & n.a. & & & & & & & & \\
\hline \multicolumn{21}{|l|}{ Time 5} \\
\hline 10. Relationship conflict & 2.39 & .52 & .87 & .22 & .27 & -.29 & .51 & .46 & -.39 & .54 & .32 & -.42 & .85 & & & & & & & \\
\hline 11. Task conflict & 2.65 & .38 & .89 & .07 & .54 & -.27 & .55 & .65 & -.41 & .61 & .60 & -.45 & .72 & .68 & & & & & & \\
\hline 12. Trust & 5.43 & .46 & n.a. & -.16 & .01 & .52 & -.45 & -.31 & .69 & -.35 & -.19 & .72 & -.60 & -.47 & n.a. & & & & & \\
\hline \multicolumn{21}{|l|}{ Time 6} \\
\hline 13. Relationship conflict & 2.34 & .45 & .87 & .39 & .15 & -.32 & .60 & .49 & -.40 & .58 & .32 & -.33 & .64 & .50 & -.47 & .85 & & & & \\
\hline 14. Task conflict & 2.61 & .33 & .89 & .28 & .46 & -.30 & .66 & .69 & -.27 & .64 & .61 & -.35 & .52 & .76 & -.35 & .57 & .71 & & & \\
\hline 15. Trust & 5.43 & .45 & n.a. & -.41 & -.25 & .69 & -.60 & -.49 & .72 & -.52 & -.37 & .76 & -.74 & -.61 & .76 & -.63 & -.53 & n.a. & & \\
\hline $\begin{array}{l}\text { 16. Team effectiveness - } \\
\text { self-perception }\end{array}$ & 3.88 & .32 & .80 & -.36 & -.14 & .46 & -.47 & -.42 & .60 & -.45 & -.30 & .65 & -.48 & -.43 & .64 & -.54 & -.41 & .79 & .81 & \\
\hline $\begin{array}{l}\text { 17. Team effectiveness - } \\
\text { stakeholder measure }\end{array}$ & 3.58 & .32 & .90 & -.39 & -.14 & .48 & -.36 & -.41 & .45 & -.33 & -.23 & .58 & -.37 & -.34 & .43 & -.36 & -.35 & .53 & .65 & .95 \\
\hline
\end{tabular}

Notes. $M=$ mean; $S D=$ standard deviation; $R_{w g}=$ mean inter-rater reliability of all teams; n.a. = not applicable. For all variables except team effectiveness stakeholder measure: $N=41$, and correlations above .31 are significant at $p<.05$, correlations above .40 are significant at $p<.01$; For team effectiveness stakeholder measure: $N=28$, and correlations above .37 are significant at $p<.05$, correlations above .44 are significant at $p<.01$; Internal consistencies of the scales (Cronbach's alpha) are presented in bold printing on the diagonal. 


\section{Patterns of Conflict and Trust across Teams}

In addition to examining the changes over time of conflict and trust as separate variables, we also wanted to examine if these constructs co-varied over time in such a way that specific patterns across teams could be distinguished. Therefore, we performed a cluster analysis on task conflict, relationship conflict, and trust at the five measurement moments. Following Russell (2001), we used Ward's hierarchical method with squared Euclidian distances (Hair et al., 1995) and we identified two separate clusters based on the dendrogram ${ }^{6}$. This two-cluster solution represented the simplest structure possible that still produced homogeneous groupings (Hair et al., 1995). The two clusters represented distinct patterns of conflict and trust development. To substantiate the robustness of the cluster solution and to examine the differences between the clusters in more detail, the clusters were further analyzed with regard to the levels, evolution, and correlations of the variables. First, to compare the levels and evolution of task conflict, relationship conflict, and trust, we used these variables as dependent variables and cluster membership as independent variable in a MANOVA. Table 3.2 shows the means, standard deviations, $F$ - and $p$-values for the two clusters.

Results of the MANOVA indicated a significant multivariate effect $\left(F_{(15,25)}=7.29, p<0.00\right)$ for differences in task and relationship conflict and trust between the clusters. All univariate analyses indicated significant differences between these variables at all measurement moments, except for task conflict $\left(F_{(1,39)}=3.07, p=0.09\right)$ and trust $\left(F_{(1,39)}=3.87, p=0.06\right)$ at time 2 . Although we had expected that differences in the level of trust early on would be the associated with the different patterns, it seems that this is rather the level of early relationship conflict. Overall, the teams in cluster 1 are characterized by higher reported levels of task and relationship conflict and lower levels of trust than the teams in cluster 2. Figures $3.1 \mathrm{a}$ and $3.1 \mathrm{~b}$ display the mean levels of these variables across measurement moments for cluster 1 and 2 respectively.

Thus, the teams in cluster 1 and 2 differed with regard to their levels of conflict and trust. Additionally, visual inspection of figure $3.1 \mathrm{a}$ and $3.1 \mathrm{~b}$ yields the impression that these clusters also differ with regard to the way these variables develop over time. The teams in cluster 1 seem to be unstable, whereas the teams in cluster 2 seem to be stable on conflict and trust. To test these impressions, within-cluster repeated measures MANOVAs were performed for each cluster to test the stability over time. For cluster 1 , a significant time effect was found with respect to relationship conflict $\left(F_{(4,17)}=5.12, p<.01\right)$, task conflict $\left(F_{(4,17)}=4.16, p<.05\right)$ and trust $\left(F_{(4,17)}=5.28, p<.01\right)$. Thus, the teams in this cluster experienced increasing levels of task and relationship conflict and decreasing levels of trust. For cluster 2 , the time effects for relationship conflict $\left(F_{(4,16)}=2.79, p=\right.$ n. s. $)$, task conflict $\left(F_{(4,16)}=.83, p=\right.$.n. s. $)$ and trust $\left(F_{(4,16)}=2.51, p=\right.$ n. s. $)$ were not significant. Thus, the teams in cluster 2 experienced a stable pattern of relationship conflict, task conflict, and trust.

\footnotetext{
${ }^{6}$ The results of this analysis can be obtained from the first author. In the book chapter Raes, A. M. L., Heijltjes, M. G., \& Glunk, U. Exploring temporal patterns of trust and conflict in teams. Time in Organizational Research: Approaches and Methods (Eds. Roe, R. A, Waller, M. J. \& Clegg, S.). Routledge [forthcoming], where the cluster analysis was performed on relationship conflict and trust only, three clusters were identified. In this analysis, one of the clusters contained teams with the stable pattern of conflict and trust, whereas the two other clusters contained teams with unstable patterns that only differed with regard to the levels of relationship conflict and trust. Thus, the results of both chapters and analysis approaches are compatible, as the two forms of the evolutionary patterns - stable versus unstable - were found in both analyses.
} 
Table 3.2. Results of MANOVA of conflict and trust between the three clusters

\begin{tabular}{|c|c|c|c|c|c|}
\hline & \multicolumn{2}{|c|}{ Cluster $1(N=21)$} & \multicolumn{2}{|c|}{ Cluster $2(N=20)$} & \multirow[b]{2}{*}{$F^{1}$} \\
\hline & $M$ & $S D$ & $M$ & $S D$ & \\
\hline Relationship conflict time 2 & 2.21 & .09 & 1.94 & .09 & $4.83^{*}$ \\
\hline Relationship conflict time 3 & 2.42 & .07 & 1.90 & .07 & $29.23 * *$ \\
\hline Relationship conflict time 4 & 2.59 & .08 & 2.10 & .08 & $18.34^{* *}$ \\
\hline Relationship conflict time 5 & 2.75 & .08 & 2.02 & .08 & $38.50 * *$ \\
\hline Relationship conflict time 6 & 2.65 & .07 & 2.01 & .07 & $41.93 * *$ \\
\hline Task conflict time 2 & 2.70 & .07 & 2.52 & .07 & 3.07 \\
\hline Task conflict time 3 & 2.76 & .06 & 2.41 & .06 & $15.69 * *$ \\
\hline Task conflict time 4 & 2.79 & .07 & 2.43 & .07 & $12.18 * *$ \\
\hline Task conflict time 5 & 2.90 & .06 & 2.39 & .06 & $35.44 * *$ \\
\hline Task conflict time 6 & 2.83 & .05 & 2.38 & .06 & $33.82 * *$ \\
\hline Trust time 2 & 5.49 & .07 & 5.70 & .07 & 3.87 \\
\hline Trust time 3 & 5.44 & .08 & 5.82 & .08 & $12.51 * *$ \\
\hline Trust time 4 & 5.28 & .08 & 5.62 & .08 & $9.82 * *$ \\
\hline Trust time 5 & 5.23 & .09 & 5.64 & .09 & $10.16 * *$ \\
\hline Trust time 6 & 5.16 & .08 & 5.71 & .08 & $24.29 * *$ \\
\hline
\end{tabular}

${ }^{1} d f=(1,39)$; Reported are the univariate results. Multivariate effect: $F_{(15,25)}=7.29, p<.00$

Notes. $M=$ mean; $S D=$ standard deviation; ${ }^{*} p<.05 .{ }^{* *} p<.01$

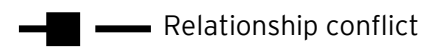

Conflict

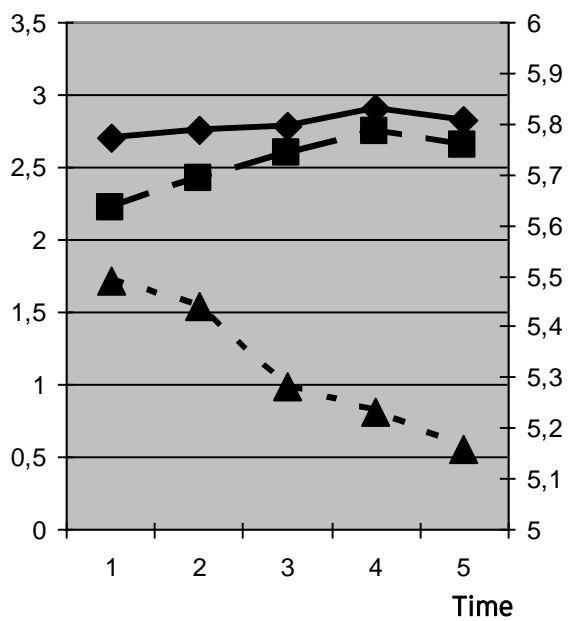

Figure 3.1a. Relationship conflict, task conflict and trust levels for teams in cluster 1

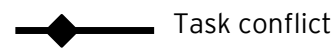

- - Trust

Conflict

Trust

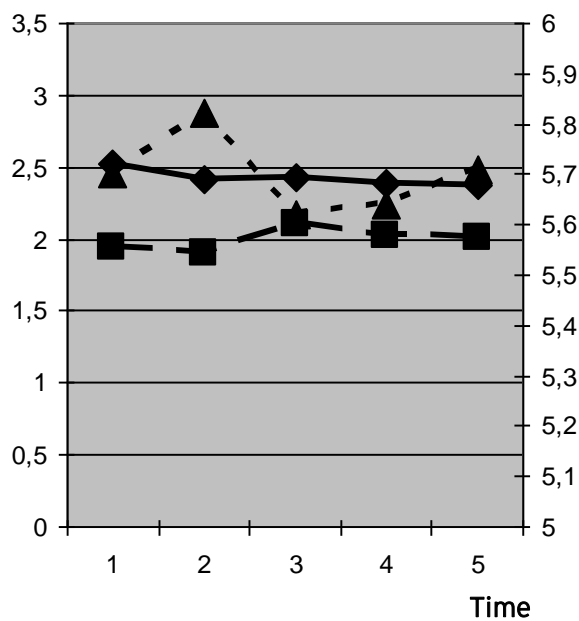

Figure 3.1b. Relationship conflict, task conflict and trust levels for teams in cluster 2 
We also examined the correlations between task and relationship conflict for the teams in the different clusters, expecting that these correlations would be weaker for the teams with the stable pattern (cluster 2) than for the teams with the unstable pattern (cluster 1). To support the hypothesized mechanism, the correlations between task conflict at time ${ }_{x}$ and relationship conflict at time $_{x+1}$ should be higher in cluster 1 than in cluster 2 . For cluster 1 , the mean of these correlations over time was $.15(S D=.25)$. For cluster 2 , the mean of these correlations was .31 ( $S D=.29)$. Thus, we found the opposite from what was expected: The teams with the unstable and deteriorating pattern showed lower correlations between task and relationship conflict than teams with the stable pattern.

Based on these analyses, it can be concluded that we found mixed support for hypothesis 2 . The hypothesis is supported with regard to the level and evolution aspects of the patterns. One category of teams developed stable high trust and low conflict, whereas another category developed a pattern of decreasing trust and increasing task and relationship conflict. However, early relationship conflict rather than early trust seems to have been an important aspect of initial conditions associated with subsequent patterns. Furthermore, the teams with the unstable pattern showed lower correlations between task and relationship conflict at each measurement moment than the teams in the stable pattern.

\section{Patterns of Conflict and Trust and Team Effectiveness}

To test if team effectiveness would be higher for teams with the stable pattern than for those with the unstable pattern (hypothesis 3 ) and because of the unequal sample sizes for the effectiveness measures, we performed separate univariate analyses of variance with team selfperceived and stakeholder effectiveness as dependent variables and cluster as independent variable.

The results showed significant cluster effects for both measures of team effectiveness ( $F_{\text {team }}$

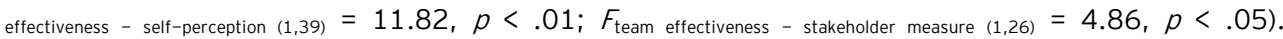
Inspection of the means showed that the teams in cluster 1 report significantly lower levels of team effectiveness $(M=3.73, S D=.33)$ than teams in cluster $2(M=4.03, S D=.22)$. On the stakeholder measure of team effectiveness, the pattern was similar with the teams within cluster 1 performing worse $(M=3.47, S D=.33)$ than those in cluster $2(M=3.70, S D=.32)$, supporting hypothesis 3.

\section{Discussion}

\section{Trust and Conflict Development in Teams}

Our results show that conflict and trust are not stable over time and that discernable patterns of these variables exist across teams over time. The results from this study are partly in line with previous research on team development (Chang et al., 2003; Jehn \& Mannix, 2001; Jones \& George, 1998; Tuckman, 1965), but also give rise to new considerations regarding the temporal nature and co-variance of task conflict, relationship conflict, and trust over time in teams with complex tasks in natural organizations. We argued that the general way in which the variables would change over time were a decrease in relationship conflict, an increase and then decrease in task conflict, and an 
increase in trust. Relationship conflict significantly increased at the midpoint of the team's life; trust decreased, not gradually over time, but with a sharp decrease around the midpoint; task conflict did not significantly change over time. Thus, although punctuated equilibrium theory has been proposed to primarily relate to task related aspects of team interaction (Chang et al., 2003; Gersick, 1988, 1989), we found a midpoint transition only with regard to socio-emotional aspects of team interaction. Moreover, as our teams were student management teams performing managerial tasks not related to a particular project deadline, our results suggest that the midpoint transition might also be triggered by the awareness of the total amount of time that is left before the teams stop working instead of a specific task-related deadline. Both findings point at a possible broader applicability of punctuated equilibrium theory than was initially proposed.

Furthermore, two main patterns of trust and conflict evolution were observed in our sample: a stable pattern with moderate conflict and high trust and an unstable deteriorating pattern with decreasing levels of trust and increasing levels of conflict over time ${ }^{7}$. This unstable deteriorating pattern was hypothesized to result from the continued reinforcement of task and relationship conflict over time when early trust was low. In line with recent theory that emphasizes the joint evolution of processes and states over time (Arrow et al., 2000; McGrath et al., 2000) and from what we had expected from previous, mainly cross-sectional, research on conflict and trust (De Dreu \& Weingart, 2003; Peterson \& Behfar, 2003; Simons \& Peterson, 2000), we found that clearly distinguishable patterns existed across teams over time. These patterns were also related to both self-perception and stakeholder measures of team effectiveness, in such a way that the teams with the stable hightrust-low-conflict pattern were more effective than teams with the unstable pattern. Possibly, this stable level of trust reflects a qualitative shift from conditional to unconditional trust (Jones \& George, 1998), which was, however, not reflected in a higher level of trust.

However, some contradictory results were also found. We had expected that differences in early levels of trust would be associated with the subsequent evolution of task and relationship conflict. However, we did not find a significant difference in trust between the teams in the two clusters at the first measurement moment, although the effect was in the expected direction and almost reached significance with $p=.06$. Furthermore, within the cluster of teams with the stable pattern, correlations between task and relationship conflict were higher than those for the teams with the unstable pattern, suggesting that the misattribution hypothesis might not have been the explaining mechanism in this case (Simons \& Peterson, 2000). Since our study was the first to assess conflict and trust evolution over a long period of time, it is not unthinkable that previously proposed mechanisms work differently over long periods of time. When team members have worked together very intensely for a long period, as was the case for the teams in our sample, misattribution might not occur anymore, because team members have come to know each others' intentions and behavior very well. Another issue that is potentially related to these contradictory findings around the correlations

\footnotetext{
${ }^{7}$ It should be noted here that even the lowest level of trust was still relatively high with 5.16 on a 7 -point scale. These high levels of trust would be in line with the notion that trust partly reflects the security people feel in a situation because of guarantees and safety nets, provided by the institution of which they are part (McKnight et al., 1998). The student associations might have provided such institution-based trust for the respondents in our sample.
} 
between task and relationship conflict, is the relatively low internal consistency that was found for task conflict. Therefore, our results should be interpreted with some caution.

Primarily based on Tuckman's model, we had expected to find an increase in trust in the teams. However, such an increase was not found in either the analysis of the variables separately or within the patterns. This finding is noteworthy, as an increase of trust is often assumed to result from the increased familiarity among people when working together. Several explanations could exist for not finding this increase. The first is simply that such an evolution in teams does not exist among members from organizational teams, or did not exist in our sample. The trust experience in the beginning of team functioning would then be the maximum level that is possible, whereas the conflict level in the beginning is the lowest possible, perhaps because teams operate under politeness norms (Jehn \& Mannix, 2001). As advocated by George and Jones (1998), it is beneficial for team members to start with high levels of trust, because of the large incentive that exist for high-trust relationships for people that have to work together closely for a prolonged time period. A second, methodological, explanation could be that we have observed a ceiling effect in our sample. Since initial trust levels were high, it was almost impossible to score significantly higher on our measure than the initial level.

A third explanation lies in the moment of our first measurement of trust. Time 2 was scheduled when the teams had been together for about three months. In terms of group development, much will have happened before this moment. Although Tuckman (1965) has suggested that developmental stages will take longer or shorter depending on the total life-span of the group (and thus, in our sample, each developmental phase could theoretically take about two months), it is unlikely that the development to the performing stage of team functioning would take six to eight months. Thus, we may have missed an increase in trust occurring in the first three months.

All in all, our temporal perspective on three commonly investigated aspects of team functioning - task conflict, relationship conflict, and trust - allowed greater insight into the nature of these variables as well as common evolutionary patterns that also make a difference for team effectiveness. The discovery of the prevalence of the unstable deteriorating pattern and the absence of teams with increasing trust over time, adds important insight to the general belief that teams over time develop better ways of handling team processes and interpersonal relationships.

\section{Implications for Further Research and Limitations}

Although we think that our research has added valuable knowledge about trust and conflict evolution in teams, we also see some limitations that should be addressed. Thereafter, we will outline the implications of our research for research and practice.

As outlined before, our first measurement of trust and conflict was relatively late, which limits our knowledge about the development of these variables during the important first phase of team development. Since we collected team composition variables at time 1 and because we needed to ensure cooperation of all team members during all six measurement moments over the 10-month period, we did not want to overburden the team members with too lengthy a questionnaire at time 1 . In addition, as the existing longitudinal research on teams has typically covered the first two or three months of team functioning (Jehn \& Mannix, 2001; Peterson \& Behfar, 2003), we were interested in examining a time span considerably longer and we showed that after this first phase, interesting 
patterns are to be discovered. Yet, it is our main recommendation for future investigations to address this initial period and study trust evolution for some weeks or months from the very beginning of a team's existence with fine-grained (e.g., daily or weekly) measures. It would be interesting to see if trust would increase and Tuckman's transition between storming and norming phases could be observed in this period.

An additional aspect of teams' initial conditions which could be worth investigating, is the extent to which previously existing relationships between team members influence the patterns over time. Although we did have some information on how the teams in the sample were brought together, possibly indicating differences in familiarity, and did not observe clear differences, the extent to which the onset of patterns is influenced by differences in familiarity of the team members instead of the level of trust, this factor remains an uncertainty. Differences between the teams in their degree of familiarity before they entered the management team could explain differences in initial trust levels. However, as we were mainly interested in assessing the temporal nature of conflict and trust over a long time period and in examining discernable patterns over time, it was not our main focus to study the initial conditions that led to these patterns.

Some further avenues for future research can be outlined. First, future research should try to replicate the occurrence of the stable and unstable patterns of conflict and trust as found in our study. It would be interesting to observe if the shape of the patterns and the two distinct forms as we found here, can be observed in other samples of teams performing complex tasks over shorter or longer time spans, in different organizational settings, and with different team structures.

Second, it would also be interesting to study the onset of these patterns. Whereas our research has shown the existence of discernable patterns among teams, we do not know yet why some teams end up in a downward spiral, while other teams remain stable in conflict and trust levels. Complexity theory would argue that differences in initial conditions might be an important variable to consider when explaining the two patterns (McGrath \& Tschan, 2004), a notion that has been supported by other team research on early successes and failures in a team's life (Ericksen \& Dyer, 2004). When examining initial levels of trust, a key question is whether trust can develop without constraints and, when a high level has been achieved, displays a stable pattern, or whether trust at the very start of the team's life determines the development over time. Next to the level of trust, the type of trust could be an important variable to examine. It would be interesting to carefully analyze Jones and George's (1998) proposition of a qualitative distinction between conditional and unconditional trust. The existence and causes of early conflict might also be interesting to study, as this might have strong consequences for the pattern in which teams find themselves later on.

Analyzing initial conditions can also include demographic and personality characteristics of team members to gain insight into how team composition influences team development over time. Since team composition has been linked to aspects of team functioning in numerous studies (Harrison, Price, Gavin, \& Florey, 2002; Jehn \& Mannix, 2001; Pelled et al., 1999), it possibly also influences patterns of conflict and trust that evolve over time.

Next to examining aspects of team composition and initial levels of conflict and trust, it would be interesting to study possible mechanisms underlying patterns of conflict and trust. For example, the concept of reflexivity - the extent to which team members overtly reflect upon, and communicate 
about the groups objectives, strategies, and processes, and adapt them to current or anticipated circumstances (Schippers, Den Hartog, Koopman, \& Wienk, 2003; West, 1996) - might be such a mechanism. Reflecting upon their own processes might be one mechanism by which teams with the stable patterns maintain trust and prevent task conflict to evolve into relationship conflict.

Along the same line, it would be interesting to study how and if managerial, coaching, or training interventions could influence the development of these patterns. Since more than half of the teams in our sample showed decreasing levels of trust and increasing levels of conflict, and since this pattern was associated with lower levels of team effectiveness than teams with high and stable levels of trust and low conflict, it would be interesting to study which interventions could reverse this pattern. Apart from the theoretically interesting question of whether it is possible to change a downward spiral, such knowledge could be useful for organizational teams and team managers.

A more general implication of our temporal focus is that it points to the necessity for new theories that acknowledge temporality. Now it is not only the level of variables, such as conflict and trust, which exerts influence, but also temporal aspects of these variables, such as the duration, onset, and offset (Roe, 2005, 2008). Would a short, but intense conflict within a team have the same impact as a milder but prolonged conflict on team effectiveness? How exactly does trust become destroyed and recovered? Additionally, the timing of events and process characteristics might have an impact on team effectiveness, trust, or conflict (Waller, 1999). Furthermore, the stability or instability of conflict and trust levels per se could influence team effectiveness, because adapting to changing situations might distract valuable time and energy from a team's task behavior.

Finally, this study also has some methodological and procedural implications for researchers who want to track teams over longer time periods. Although the demands on researchers' time and patience are considerable, carefully thinking and planning how to use existing possibilities well might lead to unexpected opportunities for data collection. In our case, the availability of these student management teams that functioned in a stable composition for the period of one year and of which a whole cohort of teams started at the same time, provided a unique possibility for tracking team dynamics over a long period. We also specifically decided to make personal visits to every team at every measurement moment, which ensured motivation and cooperation from participants.

\section{Conclusion}

This study has contributed to the understanding of temporal aspects of conflict and trust in teams. The most effective teams showed a typical pattern of high trust and low conflict that was stable over time. In contrast, in less effective teams, trust levels were lower and decreased over time, whereas both task and relationship conflict increased. All in all, we have demonstrated what previous researchers had assumed, that trust and conflict can be dynamic and that studying differences in the evolution of these concepts provides incremental insight into team functioning. Given that this is one of the first studies empirically examining evolutionary patterns of conflict and trust in organizational teams, we hope to have demonstrated the value of a temporal perspective on team functioning. As such, we have begun to "reground the study of groups in the reality of group life as it occurs in the world" (McGrath et al., 2000, p. 95). 


\section{Appendix}

\section{Items measuring team effectiveness - stakeholder measure}

1. During the past year, I have been satisfied with the state of affairs within the association.

2. During the past year, the board has contributed to a good atmosphere within the association.

3. The board performed well with respect to its daily activities.

4. During the past year, I have been satisfied with the accessibility of the board.

5. The board was open to ideas of the members.

6. The board made clear what decisions were taken.

7. During the past year, I have been satisfied with the communication between the board and the members.

8. The board contributed to the development of new activities.

9. The board implemented improvements.

10. During the past year, I have been satisfied with the commitment of the board towards the members.

11. During the past year, I have been satisfied with the functioning of the board of my student association.

12. Conflicts within the association were handled well by the board.

13. During general meetings with the members, the board performed according to my expectations.

14. The board lived up to their promises.

15. The board implemented innovations.

16. The board did not incorporate the long terms goals of the association in its policy. (reverse scored)

17. The board informed the members about the current state of affairs.

18. The board handled unforeseen circumstances adequately.

19. The board performed its task seriously and professionally.

20. External conflicts (that is, with parties outside the association) were handled well by the board.

21. The board appeared enthusiastic.

22. The board realized its goals. 


\title{
4
}

\section{Top Management Team and Middle Managers: Making Sense of Leadership}

\begin{abstract}
This study provides insight about the process of top management team (TMT) sensemaking about leadership of middle managers - a process that has so far been neglected by researchers. In a longitudinal case study design, we analyzed observational data from 23 TMT meetings and transcripts from interviews with TMT members. Results indicate that TMT sensemaking consisted of images of middle managers, the TMT self-image, and reflection on action and action planning. Furthermore, the importance of TMT unity in actions toward middle managers is highlighted as an important aspect of TMT leadership. It is suggested to incorporate TMT sensemaking about leadership, as well as actual leadership actions toward middle managers, as processes for explaining how TMT composition influences organizational performance.
\end{abstract}

This chapter is based on:

Raes, A. M. L., Glunk, U., Heijltjes, M. G., \& Roe, R. A. (2007). Top management team and middle managers: Making sense of leadership. Small Group Research, 38, 360-386. 


\section{Introduction}

During the 1980s, both scholars and managers started to emphasize the importance of top management teams (TMTs) for steering strategic decision making and organizational performance. Different from other types of teams, a TMT has been defined as the aggregate informational and decisional entity through which the organization operates and which forms the inner circle of executives who collectively formulate, articulate, and execute the strategic and tactical moves of the organization (Eisenhardt, Kahwajy, \& Bourgeois, 1997; Klenke, 2003). Predominantly drawing on upper-echelons theory (Hambrick \& Mason, 1984), a vital stream of research has emerged that relates TMT characteristics to strategic decisions and organizational performance. Although this research has succeeded in underlining the general value of a team-based approach to strategic decision making, reviews have repeatedly concluded that findings are inconsistent, especially concerning the relationship between TMT composition and organizational performance (Cannella \& Holcomb, 2005; Carpenter, Geletkanycz, \& Sanders, 2004; Certo, Lester, Dalton, \& Dalton, 2006).

Critics of upper-echelons research have diagnosed two interrelated areas of concern: TMT researchers' reliance on databases and large-scale surveys and the related neglect of processes that link TMT composition and decision making to organizational performance (Pettigrew, 1992; Priem, Lyon, \& Dess, 1999; see also chapter 2 of this dissertation). To gain more insight into these processes, qualitative and longitudinal research methods have been advocated, the use of which should lead to a more realistic picture of how strategic decisions are made in real-world firms (Cannella \& Monroe, 1997; Carpenter et al., 2004; Samra-Fredericks, 2000; see also chapter 2). This study aims to respond to both concerns by presenting a qualitative study of a process through which TMTs influence organizational performance.

We used a case study design to study the TMT of a medium-sized Dutch public organization. The first author attended 23 TMT meetings during 6 months and conducted in-depth interviews with individual TMT members. She was also allowed full access to the organization's documents and the minutes of TMT meetings. We expected that the TMT would use its meetings to exchange information on various strategic issues, to discuss different courses of action, and to make decisions, but an unexpected theme emerged that, without being formally scheduled, repeatedly turned up during the meetings and also appeared unprompted during the interviews. This was the TMT's responsibility for ensuring decision implementation through the next echelon. Intrigued by the obvious importance of this leadership task for a TMT, we decided to follow this thread more thoroughly.

The concept of sensemaking is used to explain how the TMT understands and acts on its leadership role (see Weick, 1995). More specifically, we analyzed how TMT members collectively make sense of their relationship with middle managers (MMs) and reason how this can be expected to influence decision implementation. In the following parts of this chapter, we describe the role of TMT leadership toward MMs and identify the absence of a relational dimension between TMT and MMs as a gap in existing TMT research. Then, we emphasize TMT sensemaking as a key process and formulate our research question. Thereafter, we describe our research methods and analysis of the qualitative data. Finally, we present our results, discuss these in light of existing theory, and formulate suggestions for further research. 


\section{TMT Leadership toward MMs}

Leadership can be defined as "the process of influencing others to understand and agree about what needs to be done and how to do it, and the process of facilitating individual and collective efforts to accomplish shared objectives" (Yukl, 2006, p. 8). The concept of strategic leadership, more specifically, is used to designate leadership at the top of organizations and has been described as a strategic and relational activity between leaders and their immediate followers (Vera \& Crossan, 2004). Upper-echelons theory has focused on strategic leadership as a team-based activity and has emphasized the strategic aspect of the TMT task. However, this theory tends to downplay the role of relational aspects of leadership (Cannella \& Monroe, 1997). This relational aspect of strategic leadership has been extensively studied on the level of the individual CEO, for example, by investigating the effectiveness of transactional and transformational styles (see Yukl, 2006, for an overview of leadership styles). As this research illustrates, relational aspects of top leadership are key for ensuring decision implementation and organizational performance.

TMT researchers have mainly focused on intra-TMT factors, such as the team's composition or decision-making process, and have studied how these factors relate to organizational performance (Certo et al., 2006). With this strong internal focus, it seems almost as if upper-echelons research has conceived of the TMT as an independent, not to say omnipotent, entity that directly influences organizational performance without any intermediary process. Realists, or those with senior executive experience, might find this all the more surprising, as the political reality within organizations clearly shows how much TMTs depend on MMs (Balogun \& Johnson, 2004; Currie \& Procter, 2005). As stated by Weick (1979), it is the pattern of relationships within organizations, not the fact that "great men" sit at the top of them, which makes it possible to exert influence and enhance organizational performance - a statement that is clearly in accord with relational views of power in organizations (Clegg, Courpasson, \& Phillips, 2006).

Managing the interface with MMs can be considered an important aspect of the TMT task because of the catalytic role that MMs play in the implementation of strategic decisions (Balogun \& Johnson, 2004). In this article, the term middle manager (or MM) is used to denote the management layer between the TMT and first-level supervisors (i.e., managers of divisions or subsidiaries; Dopson, Stewart, \& Risk, 1992). MMs are important for creating alignment in organizations and influencing organizational performance (Balogun \& Johnson, 2004; Currie \& Procter, 2005; Floyd \& Wooldridge, 1997). They are also found to be able to redirect strategies, delay implementation, reduce the quality of implementation, and sometimes even sabotage it completely (Guth \& MacMillan, 1986). This can occur in situations where MMs' self-interest is at stake, when they perceive the new strategy as flawed, or when they are incapable of implementing it (Guth \& MacMillan, 1986). Thus, to be effective, top managers have to find ways to gain MMs' commitment or, at least, their compliance.

\section{TMT Sensemaking about Leadership}

Strategic leadership on the TMT level implies that the process of influencing others to achieve shared objectives is carried out by more than one person. Thus, TMT leadership contains an extra, collective dimension as compared to leadership on the individual-CEO level. TMT members will have to coordinate and align their individual ideas and actions to develop a common understanding of their 
leadership approach that they carry out collectively. However, to our knowledge, no studies have reported how TMT members understand this leadership aspect of their task. In our initial observations, we observed that leadership issues were indeed surfacing during TMT interaction, and we decided to study this issue more systematically. To understand and describe how leadership issues play a role in TMT interaction, we use the concept of sensemaking.

Sensemaking is a process through which individuals make sense of uncertainties in the environment through interaction with others (Weick, 1979, 1995). This way, they negotiate among themselves an acceptable account of what is going on. This process of interpreting events to create meaning is triggered by perceptions that events are somehow ambiguous, surprising, or confusing (Maitlis, 2005). Because TMTs must comprehend a great deal of vague, ambiguous, and often conflicting information from many sources (Edmondson, Roberto, \& Watkins, 2003), including information related to MMs, sensemaking seems an adequate concept to capture characteristics of TMT interaction about leading MMs. Recent research shows that a team context is particularly suitable for sensemaking, as the interdependence and team identity create a setting in which team members interpret their collective experiences and construe attributions of those experiences (Robertson, 2006).

Sensemaking is intimately connected to action. Action both precedes interpretation and meaning giving and follows it. Weick (1995) has used the concept of enactment to describe the phenomenon that when people act according to the sense they see, they construct parts of their environment. Thus, sensemaking is an iterative process of meaning giving and enactment (Weick, Sutcliffe, \& Obstfeld, 2005). Moreover, characteristics of the sensemaking process are consequential for the actions that follow (Maitlis, 2005). Sensemaking is also adaptive over time when truths of the moment change, develop, and take shape over time; it is only when the content of sensemaking is both believed and doubted that systems are able to learn and update their actions and meanings in ways that adapt to changes in the system and its context (Weick et al., 2005).

TMT sensemaking has been studied during strategic change (Gioia \& Thomas, 1996), in the context of shared cognitions about strategy (Knight et al., 1999), and in terms of the interpretative ambiguity that results from cognitive diversity (Kilduff, Angelmar, \& Mehra, 2000). However, TMT sensemaking about leadership has, to our knowledge, never been addressed in previous research. The fact that sensemaking is a social process implies that at least two dimensions can be distinguished: the content and the process of sensemaking. We will focus mainly on the content of sensemaking (i.e., what sense is made) because we are interested in the concrete substance of a TMT's understanding of its leadership role. Therefore, we come to the following research question: What is the content of TMT sensemaking about leading MMs, and how can this be expected to influence decision implementation?

\section{Method}

We studied the TMT of a public organization in the Netherlands using a longitudinal case study design (Yin, 2003) with a 6-month period of observation. This qualitative approach for studying TMT interaction is in accordance with suggestions from several TMT researchers (Carpenter et al., 2004; 
Samra-Fredericks, 2000). In our case, a qualitative approach was especially appropriate because we were interested in TMT sensemaking and the TMT members' understandings of their leadership role (Brown \& Gioia, 2002).

As noticed by Jarzabkowski and Wilson (2002), in-depth case studies of top managers in action are inherently risky because they require high-quality access to senior people and often highly confidential data over time. Because gaining access to TMTs is difficult, we used the researchers' personal contacts to approach the TMT. We asked if one of the researchers could attend its weekly board meetings for 6 months and sought each member's cooperation in being interviewed about the functioning of the TMT. We informed them about the goal of the study, stating that we were interested in strategic decision making in TMTs and the factors that contribute to the effectiveness of the team. We gained approval to conduct observations and interviews under strict conditions of confidentiality.

Our focal process of interest, TMT sensemaking, is inferred from observations collected during the weekly meetings as well as from the individual interviews. Although sensemaking activities cannot be expected to be limited to official meetings, we are confident that we have covered the most substantial part of this process, as the observed TMT's weekly meetings were very extensive, lasting for 4 to 6 hours, and because managers indicated that a substantive part of their interaction took place during these meetings.

\section{The TMT and the Organization under Study}

We promised anonymity for the organization as a condition for reporting, so we refer to the studied organization as Alpha and will not reveal any details regarding the type of organization or the content of any of the strategic topics that the TMT discussed. Although this is a disadvantage for the reader (Yin, 2003), we think that even without this information, the study provides unique and valuable insights into TMT interaction.

Alpha has about 3,000 employees and operates in the public domain in the Netherlands. The organization can best be characterized as a professional bureaucracy, which implies that Alpha relies, in its structural configuration, on the skills and knowledge of its operating professionals (Mintzberg, 1983). This structure is common in general hospitals, educational institutions, public accounting firms, social work agencies, and some production firms (Mintzberg, 1983). Although Alpha operates in the public domain, the TMT has considerable freedom and opportunity for deciding on strategy, budget, size, and activities. The environment in which the organization operated during the research period can be characterized as rather turbulent: Government regulations for the industry in which the organization operated were subject to major changes that affected the choice of appropriate strategies with which to survive the turbulence.

The executive board of this organization was a TMT consisting of three members: the president, the vice president, and the chief operating officer ( $\mathrm{COO}$ ). All were male and roughly around the age of 50. Given the size of the organization, the size of this TMT is not uncommon in the Netherlands. Previous research on the top 30 companies in the Netherlands (which have an average number of employees about 10 times larger than Alpha) indicated that even in these companies, the average TMT size is five (Glunk, Heijltjes, \& Olie, 2001). In this team, only the COO had reached his 
current position through a career within the organization. The other members had entered from outside. This TMT operated as a social entity and could, therefore, be studied as an intact team. The TMT reported to the supervisory board of the organization. Although the president had the final responsibility, the team functioned on a basis of equality. This structure, where power is shared between members of the TMT, has become increasingly popular in organizations (Yukl, 2006).

The tasks of the TMT at Alpha, as stated in official organizational sources, can be described as having the final responsibility for the policy of the organization, including appointing key personnel, taking the initiative for major organizational changes (e.g., growth and restructuring), and managing finances and centralized staff functions. At the beginning of the observational period, the team had been working together for about 1 year. The president was mainly responsible for the external contacts of the organization, the vice president for finance and human resource management, and the $\mathrm{COO}$ for the internal operations of the organization. MMs in Alpha were responsible for divisions of the organization. Within the limits of general rules and procedures, these units operated with considerable autonomy. MMs formed the link between the TMT and their operational divisions, having to combine demands from the top and from the bottom.

\section{Data Sources}

Direct observation. The first author observed the 23 weekly board meetings of the TMT during six months in the period from January to June 2005. Since tape or video recording was not allowed, the researcher took detailed notes during the meetings. These notes consisted, as far as possible, of verbatim records, following recommendations of Bachiochi and Weiner (2002). To ensure accuracy and internal validity, the notes were checked with the meeting's secretary, which resulted in quasiverbatim transcripts of the meetings. In addition to these transcripts, general impressions of each meeting were written down during and immediately after each meeting. Information about one meeting that could not be observed was gained from the minutes of this meeting as well as through oral explanations from the meeting's secretary.

TMT meetings were held weekly and lasted about 4 to 6 hours. In addition to the three TMT members, a secretary and the head of the strategy department attended the meetings. An agenda, typically consisting of about 15 to 20 items, structured the course of the meetings. During most of the meetings, discussion of all items on the agenda was completed. Sometimes, items were adjourned to the following week, usually when a TMT member was absent. Agendas were always structured in the same way. First, the minutes of the previous week's meeting were reviewed and approved. Second, strategic issues were discussed, which might involve discussing a document, preparing for a meeting or talk, sharing information about events that had occurred, or discussing scenarios for the future. Further agenda items were scheduled according to topics relevant at that moment, either by TMT members themselves or at the request of others. Regularly, other people, including MMs, were invited to the TMT meetings to attend to a specific agenda item when a particular contribution was required. To coordinate their actions and activities, the TMT members also took time to review and question each other's agendas for the upcoming week, illustrating the importance placed on knowing each other's activities as well as maintaining a sense of collective responsibility. 
In observational research, it is possible that the presence of an observer will influence the situation under study. We are confident that this effect has been minimized during actual observations for several reasons. First, strict confidentiality contracts had to be signed by the researcher that prohibited revealing any sensitive information about the TMT meetings. This increased the likelihood that the TMT members would feel confident enough to follow their normal behavior. Second, because of the large number of meetings that was observed, it would have been extremely inefficient for the team to not act sincerely during the meetings and adjust decisions afterward, without the presence of the researcher. Third, the meeting's secretary, as well as the head of the strategy department, independently indicated that TMT interaction during the observational period did not differ from earlier TMT interaction.

Interviews. Interviews were conducted with each of the TMT members at two points during the study. The first round took place after five TMT meetings had been observed. These interviews lasted about 1 hour. This timing allowed us to test initial observations during the meetings and to gain knowledge about the way in which TMT members understood past developments and current issues. Interviews were semi-structured to ensure that some core questions were addressed on each occasion. For example, we asked each member to describe the strengths and weaknesses of the TMT as well as how effective he considered the team to be. The second interview round took place 4 months after the observational period. During these interviews, preliminary ideas about events and interpretations were discussed with each of the TMT members to check whether they matched the views of the team members. An initial report was presented to the TMT members for comments about 1 month after the second interview. We incorporated the comments in a first version of the article. This was presented to the TMT about 1 year after data collection was completed and elicited no further comments.

Minutes of meetings and other organizational documents. The minutes of the meetings were examined to assist in the analysis of TMT sensemaking. These documentary sources both provided a context for the researcher to understand the issues dealt with and acted as a formal record, in a minimal manner, of the understandings achieved by the participants themselves. We drew on these documentary materials to frame, verify, and occasionally deepen our understanding of the data. In addition to the observer of the meetings, a second member of the research team was allowed full access to Alpha's archive, which ensured a thorough knowledge of the history of the agenda items as well as background information for the meetings.

\section{Data Analysis}

To study the content of sensemaking from the TMT's interaction, we followed an open coding approach (Strauss \& Corbin, 1998), using the qualitative software package NVivo to code the transcripts of all 23 meetings. It should be noted that most of the meeting time was spent on sharing information, discussing strategic alternatives, and making decisions on important strategic issues. Leadership sensemaking was usually embedded in these discussions. However, in four meetings, the TMT explicitly discussed leadership issues involving MMs, which illustrates the importance and relevance of this topic for the TMT. 
Because of the confidentiality of the data, the TMT did not allow us to make use of more than two coders. In the first round of coding, we selected relevant text fragments by searching via NVivo for fragments that mentioned the term middle manager(s), the name of one of the MMs, or the organizational units led by MMs. Assuming that these fragments would comprise implicit or explicit views of the relations between the TMT and the MMs, they are labeled episodes of leadership sensemaking. All of the 23 meetings contained at least one episode of leadership sensemaking, and in total, 79 such episodes were identified. The term middle manager and the names of the individual MMs were mentioned 264 times in total in these episodes.

In the second round of coding, we wanted to structure and classify these episodes. Thus, a categorization system was developed that was grounded in the data. Two researchers separately went through all episodes to develop initial ideas about appropriate categories. These initial ideas were compared and discussed until agreement was reached. For example, agreement was reached to have no more than two levels in the categorization system for the categories to contain sufficient units of analysis for an adequate coverage of content. Then, several sensemaking episodes were coded by the two researchers separately at the beginning, middle, and end of the observational period to check the reliability of our categorization system. After some adjustments were made, agreement was reached on a final categorization system, which consisted of a category relating to images of MMs, a category for TMT self-image, and a category relating to action. Using this categorization scheme, all episodes were coded by both researchers; differences were discussed until agreement was reached. Because 1 episode could contain different categories, the total number of times we used a categorization label (241) is higher than the total number of 77 episodes. Table 4.1 shows these categories, the number of times the category was mentioned in the episodes, and representative examples of text fragments.

Having categorized the episodes, NVivo could generate a matrix that showed for all categories and all meetings the coded text fragments. This allowed us to inspect in detail for every meeting and over the course of the observational period how TMT sensemaking developed over time.

We also analyzed the transcribed interviews to trace the TMT members' individual perspectives on leadership toward MMs. Again, we used NVivo to search for fragments that mentioned the term middle manager $(s)$, the name of one of the MMs, or the organizational units led by MMs. This resulted in 12 episodes in which specific matters that related to leading MMs were discussed. Additionally, we identified 9 episodes in which leading MMs was mentioned more implicitly. For example, when a TMT member talked about the relationship between the TMT and other organizational actors in general, without specifically mentioning MMs, we included this as an episode. All TMT members spontaneously mentioned the relationship between TMT and MMs as being important, and all interviews contained at least 2 episodes.

\section{Results and Discussion}

In this study, we wanted to identify how a TMT made sense of its leadership role toward MMs as well as make inferences about how this influences decision implementation. In the following section, we 
describe the analysis of the interviews with TMT members and the transcripts of the meetings. We also discuss the results in light of existing theory and answer the research question.

\section{Results from Interviews: TMT Unity in Actions}

During the interviews, the relationship between the TMT and MMs was mentioned in several ways. First, TMT members mentioned the importance of TMT unity in actions toward MMs (6 of 21 episodes). For example, the president noted the importance of consistency in action among TMT members: "Everyone should do the same things in every situation. Otherwise, if you don't operate as a team, middle managers play off the TMT members against each other." Along the same line, the vice president pointed out, "If your employees get the impression that if you say 'turn left,' it can easily be 'right,' because another TMT member might say that, your decisions will not be readily implemented." The vice president also described an example of a situation where he got the impression that the president had said things to MMs that were contrary to what the TMT had decided earlier. His reaction was to immediately confront the president with his impressions, indicating the importance he put on unity in actions by the TMT.

Second, it became clear that all TMT members perceived decision implementation through MMs as an important, yet sometimes problematic, TMT task (5 of 21 episodes). For example, the COO noted, "Decision implementation is often a problem in Alpha. When middle managers don't want something, it is just not going to happen." As the best way to handle this, he stated, "Therefore, it is so important to keep on massaging things and have many bilateral consultations, in order to achieve legitimization for your decisions." He specifically advocated influencing people through one-to-one contacts as compared to formal meetings with all the MMs. The president mentioned a desire for more power sharing between the TMT and MMs. He would like to work with all MMs on the TMT level: "This way, your decisions will be broadly based, which is beneficial for decision implementation. Now, middle managers perceive themselves as each others' competitors."

The remaining ten episodes from the interviews dealt with various topics, such as the advantage of having a TMT in place instead of a single manager for dividing tasks: "You can sometimes make a few adjustments to the various roles of the TMT members. If, for example, one member can't deal with a certain middle manager too well, you could switch certain issues and tasks around." Furthermore, the COO mentioned, "The TMT has too much on the agenda and actually should make more room to include the people around us." Despite the limited number of episodes in this analysis to base conclusions on, it seems that leading MMs was a topic that was in the minds of the TMT members. Furthermore, the importance of decision implementation through MMs was mentioned by all TMT members, who also advocated TMT unity in actions toward them for achieving this. 
Table 4.1. Categories of top management team (TMT) sensemaking with representative text examples

\section{Category Units Representative examples}

1. Images of middle managers

a) as

idiosyncratic

individuals

b) as a barrier to decision implementation

c) as organizational element

\section{TMT self-image}

\section{Action}

a) planning

b) reflection

77
He locks himself into a position he can't get out of anymore.... He is getting himself into trouble.

That's right, he's the one we want to keep on board.

I see it differently ... he has a hidden agenda.

The ... in his organizational unit is giving him a headache. His unit is not the easiest ;

I think that [name of middle manager] is doing a tremendous job.

41 Organizational units are very independent. If you propose something that's within the scope of your responsibility, they dig their heels in. ... I I agree, but if you want to get break out of that. . . I I don't know....

What strikes me is that if middle managers don't agree on something, it can drag on and on....

They can do whatever they want, but we might come up with something totally different.

Middle managers don't want to pull the wagon, so that's why we have to do it and then they dig their heels in.

12 Yes, this is about structures, but not about puppets; I agree.... Yes, middle managers must anticipate that they will be closely watched by the TMT.

I have talked to.... He told me that he controls his middle managers by cutting off and opening up the money flow. I find that difficult. It sounds like blackmail and just arbitrariness.

37 Here we are, three people who tend to want to control things. I predict that this is not going to work out very well. As Alpha, we're so busy talking to each other. More for less control!

I would consider this a defeat for Alpha when. ... .

It's great how things seem to be going, but we're just holding our breath.

We are of two minds sometimes.

Our task-and especially your task, P-is to establish the contacts and give them the tools, but then we have to pass the ball to the organizational units

51 I want to warn him that he's underestimating the problem.

This is a bit suspicious. We really have to talk with [name of middle manager] about this.

Most important is the note about. ... Let's listen to what the middle managers have to say about this.

Then, let's prepare what we're going to say to [name of middle manager]. We have to find out how he feels about. . .

Maybe we should get the middle managers around the table here monthly or so. This has to be worked out within the organization.

In this letter, we need to be sharp.

23 I don't want to give away any control ... At the same time, you hit a sore spot.

What can we do about this? Except talk, talk, talk? We do go into the organizational units with many issues. I can well imagine that leads to stubbornness.

Do we want too much?

To what extent do we want to interfere into... ?

Is this because of the way we have started this procedure? 
The importance of such unity in action for a TMT is intuitively appealing: To successfully lead MMs, TMT members should be consistent in their actions and act as one to the outside world. Yet this intuitive logic has not been reflected in scientific knowledge on teams. As outlined before, TMT researchers have mainly focused on factors inside the team or external to the organization (Carpenter et al., 2004) and seldom on the relationship between TMT and lower echelons. Research on nonmanagerial teams has also mainly focused on internal team factors (Cohen \& Bailey, 1997), and when external activities have been taken into account (e.g., Ancona \& Caldwell, 1992), a detailed analysis of how team members coordinate their actions toward others is missing. Some indication for the importance of such a construct exists in Jarzabkowski and Searle's (2004) concept of TMT collective action, but they, too, neglect the relationship between TMT and others. Although relatively absent in research, the notion seemed important for the TMT we studied. Therefore, we propose to use the term TMT unity in actions to designate the process whereby TMT members coordinate their actions toward others in such a way that the team is perceived by others as a unified whole. In the results of the analysis of TMT interaction during the meetings, the importance of TMT unity in actions will be emphasized once more.

\section{Results from Observations: TMT Images of Leadership}

The elements of TMT sensemaking that appeared from our categorization (see Table 4.1) were the images of MMs, the TMT self-image, and action planning and reflection. Below, we will describe these categories in more detail and reflect on their implications.

Images of MMs. The TMT expressed images of MMs in three different ways: generalized images of MMs as a barrier to decision implementation, images of idiosyncrasies of specific MMs, and images of MMs as strategic organizational elements. Sensemaking of MMs as a barrier to decision implementation often occurred as a means to explain why decision implementation did not go as the TMT members would have liked. Thus, it is not surprising that when the TMT talked about the MMs as a group, they were rather critical and perceived the MMs' behavior as resistance toward TMT initiatives. A metaphor that appeared repeatedly clearly illustrates this perceived resistance, namely, the image of the MMs as people who "dig their heels in" as a reaction to TMT initiatives. The president was the first to use it in Meeting 2 in the context of a new project that was launched by the TMT: "When you propose something that is entirely within the scope of your responsibility, then they dig their heels in." Later, in Meetings 11,12, and 19, the metaphor was mentioned again by the COO and by the head of the strategy department when the TMT members were reflecting on past events and issues that did not go as well as they had expected. Moreover, the TMT assumed that the MMs felt that they "always had to come running up" and that they had a "deeply rooted distrust" of the TMT.

Thus, the TMT, in making sense of MMs' perceived behavior, referred to MMs as one group to understand why decision implementation in Alpha did not always go exactly as the members would like. This observation is in line with the fact that sensemaking occurs whenever the current state of the world is perceived to be different from the expected state of the world (Weick et al., 2005), which was also the case for this TMT. Talking about the MMs in a generalized way implies that the members saw the cause of the MMs' resistance more in the position of the MMs in the organization than in the 
MMs personally. This can be illustrated by the COO's bringing up the proposition that "middle managers are torn" or "caught in the middle" between the TMT and their organizational units.

In addition to talking about MMs as a group, the TMT discussed the idiosyncrasies of specific MMs. Thirty-seven of the 77 units in this category explicitly dealt with one specific MM in the organization about whom the TMT kept worrying because he seemed frequently not to act as the TMT wanted. The remaining 40 units dealt with other MMs, some more than others. In talking about specific MMs, the TMT discussed possible intentions, emotions, and behaviors of the MMs, for example, saying that an MM "did not operate sensibly" or "was disappointed." Where the images of MMs as a barrier to decision implementation were mostly generalized across time and situations, images of individual managers were more closely linked to certain situations or persons at a specific time. For example, when the TMT wanted an MM who "did not operate sensibly" to be kept within the organization during earlier discussions, members stated that they were willing to let him go later, should that prove more beneficial to the organization as a whole.

Talking about individual MMs focused TMT members' attention on the human side of these managers as people whose behavior, cognitions, and emotions were at issue. Sometimes this was triggered by negative evaluations of an MM. In another case, when the TMT member perceived an MM to be disappointed with a certain issue, he specifically stated that he had to "manage his expectations" because he wanted to keep him within the organization. Focusing on MMs as individuals during sensemaking can thus lead to tailored actions from which decision implementation could benefit.

TMT members also discussed the function of the MMs as strategic organizational element. For example, when a new MM had to be appointed, TMT members discussed the specific requirements for the new appointment. Working on their vision for the organization, they expressed that it would be beneficial to appoint an MM with certain characteristics as well as to design the MM's organizational function in a certain way. Furthermore, they discussed the future MM position after the restructuring of an organizational unit. In this process, some MMs were perceived to be afraid that their level of responsibilities and involvement in power relations would be reduced to an unacceptable level. The TMT members discussed their need to make clear to these MMs that they did not want this to happen. Discussing MMs as strategic organizational elements allowed the TMT to, once in a while, rethink the position of MMs in the organization. For example, the TMT considered changing the MM position and the specific contents and requirements of the job, if necessary, to adjust to a current or future situation.

Self-image of the TMT. In addition to the TMT's images of the MMs, our analysis showed references to its self-image. TMT members discussed their identity as a TMT with regard to their leadership role, addressing questions such as "Who are we as a TMT? What should we do as a TMT? Where do we want to go in future?" In doing so, TMT members made sense of their tasks and roles vis-à-vis MMs. For example, they stated that the TMT's task is to "establish contacts, give them the tools, and then pass the ball to the different departments." A metaphor that was often used, and is representative of the content of this category, is that the TMT is supposed "to pull the wagon." This implies the idea that if the TMT does not move the organizational wagon, no one will do it. Combined with the analysis of the interviews, the self-image of the TMT seems to center on being a couple of 
very hardworking people, trying to pull everyone in the organization forward. This is considered to be necessary, as the TMT sees the environment as changing in ways that MMs sometimes do not. The fact that this TMT self-image emerged from our categorization as a central concept confirms once again that we have indeed observed sensemaking, as the establishment and maintenance of identity is a core preoccupation in sensemaking (Weick, 1995).

Combination of TMT self-image and images of MMs. The TMT members would only rarely make explicit references to a specific leadership approach. However, their dominant ideas about leadership are evident from the images they exchanged. The images of the MMs and the TMT self-image imply views on how to best lead MMs. The main metaphors used - the wagon that the TMT wants to pull and the MMs who dig their heels in - suggest a relationship of two opposing forces in which the TMT keeps on pulling and the MMs resisting. Several times, the TMT members expressed their wish to be supported by MMs in pulling the organizational wagon. In the absence of this happening, the TMT members thought they had to take the lead, something boosted by their self-image as "three people with a tendency to control." Their orientation to control is further illustrated by some remarks in which they stated that they "do not want to hand over control." These images of having to take the lead and wanting to be in control point to a preference for a directive leadership approach. When discussing the idiosyncrasies of specific MMs, the TMT referred to a father-child type of relationship. For example, TMT members noted that an MM "is getting himself into trouble, and we have to get him out of it" or that "we should have a firm talk with these organizational units." This exemplifies a paternalistic leadership notion.

It is interesting that TMT sensemaking about leadership also included discussing what members thought might be the preferred leadership style by the MMs. For example, they assumed that MMs found it an ideal situation when the TMT was on vacation, which was pointed out during the meetings as well as in the interviews. Contrary to the TMT's own preferences of rather directive and paternalistic leadership approaches, members assumed that the MMs wanted a more laissez-faire type of leadership. These assumptions about the MMs' preferred leadership approaches are also in line with the perceived resistance from MMs and the expression that MMs have a "deeply rooted distrust" toward the TMT. The discrepancy between the TMT's images of leadership (directive, paternalistic) and the leadership model the TMT assumed to be desired by MMs (laissez-faire) was an important trigger for TMT leadership being a recurrent theme in the meetings and formed the need for continued sensemaking.

Thus, it appears from our observations of the TMT meetings as well as from the interviews that the TMT members exchanged images of MMs and themselves to construct shared images that helped them to make sense of their leadership role. They did not explicitly discuss these images. Usually, a certain image would be mentioned by a TMT member in the first place, after which the expressed image (e.g., the corrective father-child notion or the directive idea of the wagon that has to be pulled forward) was readily accepted by the other team members. When analyzing the observations over time, we saw not only that certain ideas were proposed and evolved into shared images but also that certain images reappeared at later moments. Thus, we noted a tendency among TMT members to invoke established images to make sense of ongoing events. 
It is interesting to note that we did not observe changes in images of the MMs or the TMT itself nor indications of changes in the leadership role. Yet we would think that such changes might occur in situations that can no longer be explained from the established images. Sticking to such images might be counterproductive, especially in situations of change or crisis (Weick, 1979; Weick et al., 2005). This focuses attention on the question of how the TMT responds to discrepant information. In our case, we saw that the TMT noted some discrepancy between what MMs would have preferred but did not use this information to adapt their views and leadership approach. We saw the coo more often referring to what he assumed to be the desired leadership style of MMs (laissez-faire) than the others. The other members seemed to trust his perspective given his internal career and used the perceived discrepancy to insist on their own preferred leadership approach. To better understand the dynamics and implications of this process, we will first discuss the enactment part of the sensemaking process.

Action planning and reflection on past actions. A typical feature of sensemaking is its iterative nature with meaning giving and enactment. In analyzing episodes of TMT interaction that related to actions toward MMs, we saw two temporal foci: planning for future actions toward MMs and reflecting about past actions and their results.

Concerning action planning, one conclusion stands out as the most clear: In the view of the TMT, action toward the MMs often necessitates talking. This can be illustrated by the fact that 24 of 51 units of analysis explicitly mentioned that the TMT planned to talk to one or several MMs. Ten other units mentioned a specific strategy to be followed when talking to MMs. Conversations with MMs were prepared in detail during TMT meetings. The TMT discussed the goal of the conversation, the tone of it, and sometimes, the specific division of roles, which points at the importance of coordinating future actions toward MMs, labeled earlier as TMT unity in actions. That is, to everyone outside the TMT (including MMs), it should be clear that the TMT is unified in its ideas and plans. Even though discussions take place within the boardroom, none of that should be visible externally.

Other action planning units involved writing memos or, on a more complex and abstract level, designing evaluation and incentive systems. In these episodes, action planning included a focus on developing standards with which organizational units could be evaluated and to which incentives could be linked. The prevalence of this type of action planning increased over the course of the observational period. This course of action was mainly triggered by the TMT's images of MMs as a barrier to decision implementation and thoughts about how to overcome resistance and motivate MMs to achieve decision implementation. Several times, TMT members expressed a wish to use more incentives, a transactional leadership notion, with which they hoped to gain MMs' support.

The TMT not only planned future actions but also reflected on past actions. This occurred in 23 units. Reflections were on past actions or behavior of the TMT itself ("I don't think we have endless discussions"; "Shouldn't we have done more here?"), their expectations from MMs ("Maybe we should not expect this from them"), and how they had approached MMs in certain issues ("We have presented that as a possibility, which is different from . . ."). Reflecting about past actions was regularly followed by expressing intentions for the future in terms of planning to communicate better and making things more clear. 
In both action categories, we saw the emphasis on direct contact and unity in actions as being the TMT's generic leadership approach. The directive leadership image came back in the team's preference for explaining and imposing as compared to listening when preparing its meetings with MMs. The paternalistic image was reflected in subtleties, such as when talking about the tone of voice that would be used in meetings with MMs. Furthermore, the intention to install incentive structures and evaluation mechanisms as means to direct and correct suggests an image of transactional leadership as an effective way to achieve decision implementation (Yukl, 2006).

These observations regarding the enactment part of the sensemaking cycle confirm the view that emerged from the analysis of the TMT's images. The TMT appears to act in accordance with the image it holds of its leadership role. Reflecting on the results of its actions, the TMT confirms the images of the MMs and of itself, deciding to persist in the leadership approach associated with it. Again, looking for trends over time, we were not able to perceive any changes. Discrepant information, in particular about middle managers resisting the approach, seemed to strengthen the earlier adopted patterns of meaning and associated action, rather than to change it.

\section{TMT Sensemaking about Leadership}

On the basis of the foregoing, we can answer the first part of our research question ("What is the content of TMT sensemaking about leadership of middle managers?"). As we have illustrated in this article, sensemaking about leadership contains three elements: (a) images of followers and their leadership expectations, (b) self-image and preferred leadership approaches, and (c) the relationship between the two as a basis for action. Consistent with the view on leadership as a relational activity (Vera \& Crossan, 2004), TMT sensemaking includes elements from both sides of this relationship: the MMs and the TMT. The category of action is indicative of the fact that meaning giving and action are closely linked in an iterative sequence (Weick, 1979). The presence of the TMT self-image as a category illustrates that identity construction is a basic function of sensemaking (Weick, 1995).

Our analysis revealed clear links between these categories-between the images of MMs and the self-image, between the two temporal foci for action, and between the images and action categories-suggesting that they form a coherent set of ideas that can be understood as the TMT's understanding about its leadership role. It was also found that the categories were reiterated over time, with images and actions confirming each other, and that there was a strong agreement between TMT members that was maintained over time. In some cases, we could observe how an image proposed by an individual member was accepted and upheld by the TMT as a whole. Furthermore, the TMT's preference for directive and transactional leadership was also reflected in its actions, even when the results of its actions were not as the members had desired.

The second part of our research question ("How can this be expected to influence decision implementation?") can be answered only partially, as our observations did not extend to the actual process of decision implementation in the organization. If we confine ourselves to what did, and did not, happen in the TMT, we see two points to make. First, sensemaking as a process of gaining a shared understanding enables the TMT to "speak with one voice," which can enhance the effectiveness of its interaction with the MMs. The importance of such TMT unity in actions toward 
MMs was also advocated in the interviews and was put into practice when the TMT prepared meetings with MMs by coordinating and clarifying in detail how it would act.

Second, we have noted a clear self-confirming tendency in the sensemaking process. The TMT's views and preferred actions remained the same during the observation period of 6 months, even though MMs were perceived to be resisting its decisions. Occasional discrepant information, showing that the approach taken had limited success, resulted in opting for "more of the same"-that is, "talking more" and "explaining even better" - rather than changing views in a new sensemaking effort. It is also interesting to note that as far as we are aware, the images of the MMs - and those of the TMT itself - were never discussed in contacts with those MMs. This points at the closed nature of the images, which prevents them from being adjusted in case of poor fit. What this implies for decision implementation can only be inferred.

Although TMT unity in action might be seen as an antecedent of effective decision implementation and achieving shared understandings through sensemaking might contribute to this, a self-confirmatory pattern of sensemaking may pose a risk when maintained over a longer period of time. There is an extensive body of literature about the need for vigilant information processing and renewed sensemaking for continuous learning and adapting (Janis, 1982; Weick et al., 2005). The theory of organizational learning (Argyris, 1999; Senge, 1990) makes similar points. These general notions also apply to the TMT and its relationship with the MMs. If the TMT fails to pick up signs of discrepant information from the side of MMs, decision implementation is most likely to suffer. Given the powerful role of the middle managers, as mentioned by Currie and Procter (2005) and Floyd and Wooldridge (1997), one would expect that self-confirmatory sensemaking will undermine decision implementation in the long run.

In Figure 4.1, the central concepts that emerged from our analysis are summarized. As such, this figure should be understood as an overview of our research rather than as a well-grounded theoretical model. However, it may serve as a tentative framework for more rigorous testing and theory development. We also included in the figure the concepts of TMT composition and organizational performance, as these are often the central variables in upper-echelons research, and we wanted to show how our model describes a mechanism through which these variables might be related. TMT composition is proposed to influence sensemaking, as characteristics of the TMT members will influence what and how they make sense (see also Weick, 1995). Content and process of TMT sensemaking are proposed to influence the TMT leadership style, TMT unity in actions, and, subsequently, decision implementation and organizational performance.

\section{Implications for TMT Research and Limitations}

The TMT literature of the past few years has shown an increasing number of studies on processes happening within the TMT (Carpenter et al., 2004). However, attention for interactions between the TMT and others in the organization has been limited thus far. Conspicuously lacking has been the interaction with MMs, who fulfill a crucial role in implementing decisions of the TMT. In our study, we have been able to study a TMT during a 6-month period, collecting and analyzing data on its relationship with MMs. We have demonstrated that transcripts of meetings are a useful source of information and that content analysis, especially when supplemented by a temporal analysis, can 
provide information on the TMT's sensemaking regarding its leadership role toward MMs. We expect that further research using these methods can shed more light on how TMTs think about and interact with MMs. There are a number of issues that require further study.

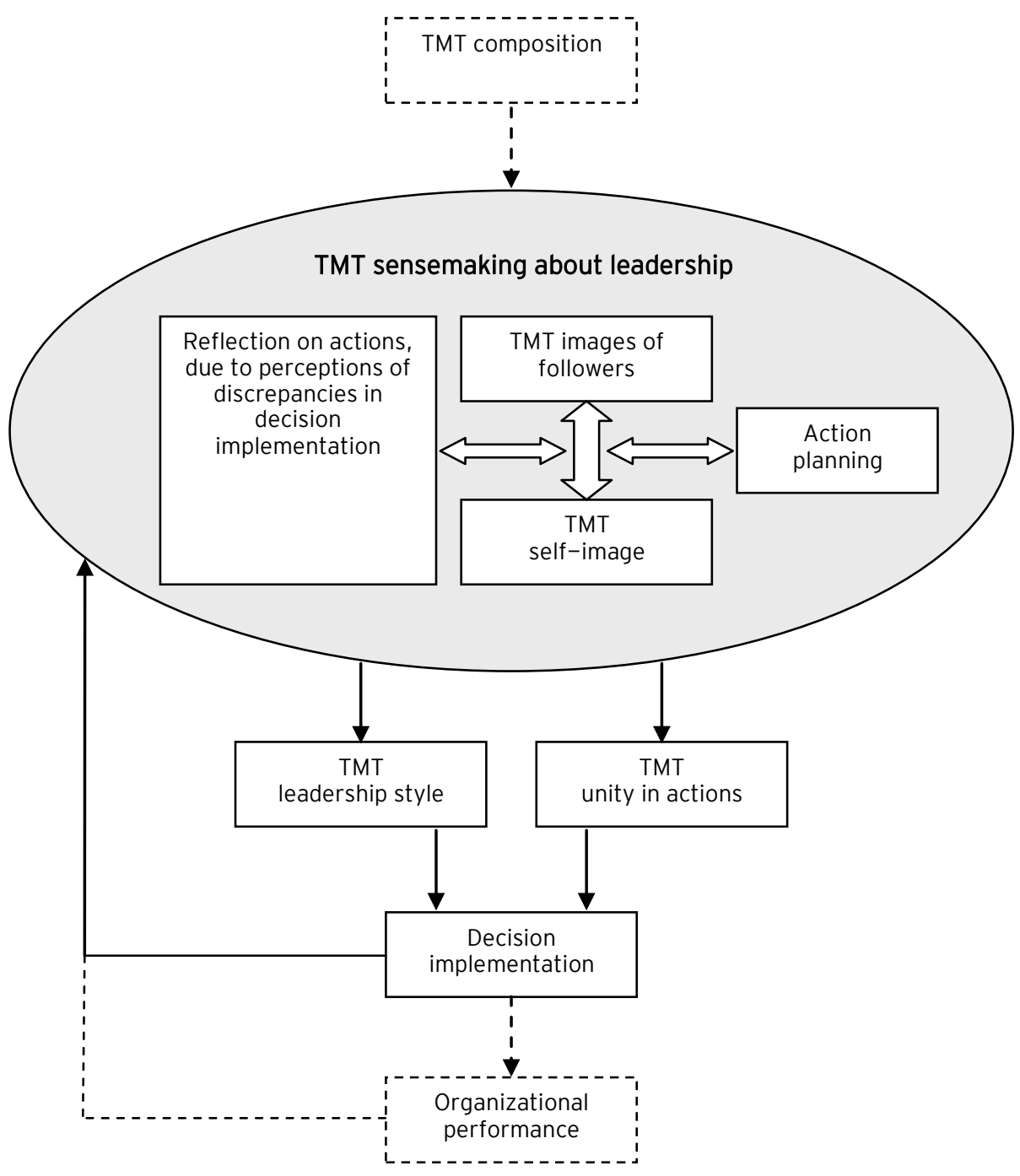

Figure 4.1. Summary and suggested model: top management team (TMT) sensemaking, leadership style, TMT unity in actions, and decision implementation as mechanisms that link TMT composition and organizational performance 
First, we recommend further study of TMT sensemaking with regard to content and changes in content over time. In our study, we did keep track of what was said in meetings, but we believe the recording could be refined. Once detailed recordings are available, analyses could be done that give a deeper insight into the social dynamics of the sensemaking process, which is especially important for understanding how shared meaning is created. Such analyses might also shed more light on the iteration of meaning generation and enactment over time and on changes in views that could be taken as signs of team learning. Along the same lines, it would be useful to replicate our way of categorizing content. Although the set of categories that we have developed seems to be reliable and exhaustive in the case of the TMT we studied, it may have to be complemented or modified in other cases, especially when TMTs in organizations with another structure or another history of power relations are examined.

Future research should also include the MMs' perceptions of the TMT - individually and collectively - particularly as they evolve over time. This would deepen our understanding of how effective the TMT is in handling the primary part of the decision implementation process. At later stages, research might be expanded to include the actual interactions between the TMT and the MMs. This would open a way to study the adequacy of the way in which the TMT defines and enacts its leadership role. Also, this could shed light on the relationships between TMT sensemaking, TMT unity in actions toward MMs, decision implementation, and organizational performance.

Our results and suggestions should be understood in light of some limitations of this study. As outlined before, we had to rely on handwritten information for our recordings, because no audio or video recording was allowed during observations and interviews. Although these accounts were checked with the meeting's secretary to ensure internal validity, some aspects of TMT interaction will have been missed because of the high speed and long length of TMT interaction during their meetings. Doubtless, real-time recording electronically would provide the best data.

A second issue is that we have used the personal contacts of the researchers to gain access to the TMT. Inasmuch as TMTs are often not very willing to allow an observer into their board meetings, using personal contacts might be one of the best possible ways to access them. However, the fact that this TMT did allow access could indicate that this team was special in some respects: It was interested in hearing the observations of a researcher, it probably felt confident about how it performed, and it was open to suggestions. Yet even in this TMT, with a particular interest in reflection, we observed a tendency for a self-confirmatory pattern of sensemaking. This would mean that our results would be an underestimation of the degree to which TMTs show such a pattern.

Finally, as with all case study research, we do not know how generalizable our findings are to other settings. We have studied the TMT of a Dutch public organization, and certain aspects of the team naturally will be influenced by aspects of Dutch culture and the type of organization. Although these aspects can and will be a source of differences in TMT dynamics, we think that our resulting theoretical interpretation is not too prone to this effect. Because we have combined the data with existing theories, the conclusions and implications for further research should be valuable across cultures and organizations. 


\section{Conclusion}

The starting point of this study was to find evidence for TMT sensemaking about leading MMs while enriching TMT research with a qualitative account of a TMT in action. Transcripts of TMT meetings and interviews were analyzed to see how a TMT made sense of its leadership task toward MMs. This has resulted in several key constructs: images of leadership during TMT sensemaking (directive, transactional, paternalistic), characteristics of the sensemaking process (self-confirmatory), and TMT unity in action as determinant of decision implementation.

More specifically, our results indicated that TMT sensemaking was organized along one dimension for understanding MMs' behavior, one for understanding its self-image in relation to MMs, and one related to the enactment of its understandings. By considering sensemaking as an iterative process, we concluded that sensemaking in the TMT that we studied could be seen as selfconfirmatory: The TMT expressed an image about leading MMs, enacted this image, and persisted in its approach, even when it encountered discrepancies in its images and those of MMs. Additionally, the importance of TMT unity in actions was emphasized as a key success factor for leadership on the TMT level. Thus, it seems that sensemaking can be seen as a process that facilitates the development of shared understandings, yet when such sensemaking leads to self-confirming cycles, decision implementation is likely to suffer. By analyzing TMT sensemaking in a qualitative and longitudinal design, we have provided insight in a so far neglected aspect of the TMT task: the relationship between TMTs and MMs as a key mechanism for ensuring decision implementation and organizational performance. 
Authors' Note. An earlier version of this article was presented on July 28, 2006, at the first annual conference of the Interdisciplinary Network for Group Research, Pittsburgh, Pennsylvania. The authors would like to thank the top management team (TMT) members who permitted the presence of a researcher during their meetings as well as the analysis of their interaction. Without their generous support, this research would not have been possible. We also thank the TMT's secretaries for their assistance in establishing internal validity of the observational data. Furthermore, we would like to thank Stewart Clegg, Barbara Lawrence, Mary Waller, the University of California, Los Angeles research seminar in the winter quarter of 2006 , and the reviewers of this special issue for their valuable comments on earlier versions of this article. 


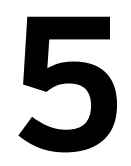

\title{
The Dimensionality of Top Management Team Performance: Expectations and Evaluations of Middle Managers
}

\begin{abstract}
To measure the outcomes of top management team (TMT) impact on organizations, researchers have often relied on indicators of financial organizational performance. This approach, however, has contributed to the current inconsistencies in models of TMT impact and neglects the inherent multi-dimensionality of the performance construct. We argue for a stakeholder approach to TMT performance and the inclusion of multiple aspects beyond financial performance. Based on literature and expert interviews, TMT performance aspects are identified and we investigate the expectations and evaluations of middle managers on these aspects. Exploratory and confirmatory factor analyses show a five-dimensional model comprising company results, strategic leadership, connectedness, TMT unity, and moral leadership.
\end{abstract}

This chapter is based on:

Raes, A. M. L., Glunk, U., Heijltjes, M. G., \& Roe, R. A. The dimensionality of top management team performance: Expectations and evaluations of middle managers. Manuscript submitted for publication. 


\section{Introduction}

The impact of top management teams (TMTs) on organizations is of central interest to scholars of organizational behavior and strategy. The performance of such TMTs can be understood as the overall assessment of how well a TMT achieves the requirements of its task (e.g., Ancona, 1989). Researchers have argued that an important indicator for TMT performance is the performance of the organization as a whole, reasoning that this is the ultimate criterion against which TMTs should be evaluated (Carpenter, Geletkanycz, \& Sanders, 2004; Hambrick \& Mason, 1984). Yet, organizational performance is influenced by many factors not directly related to the TMT (Simons, 1996) and the effects of TMTs' activities on organizational performance are likely to crystallize only after some time lag (e.g., Ancona, Goodman, Lawrence, \& Tushman, 2001). Moreover, scholars studying the performance of individuals, nonmanagerial teams, and organizations have reasoned that 'performance' is an inherently multi-dimensional construct (Cameron, 1986a; Cohen \& Bailey, 1997; Hackman, 1987). Although researchers have started addressing aspects of TMT performance beyond financial organizational performance, such as decision quality and TMT self-perceived effectiveness, insight in the dimensionality of TMT performance is lacking.

The conceptualization and measurement of team performance has since long been of interest to researchers of small groups and nonmanagerial teams (see Cohen \& Bailey, 1997, for an overview of team performance measures). In this field, researchers have suggested that the extent to which a team meets the expectations of important people in its environment is central for understanding team performance, because these people have to 'work with' the outcomes of the team (Hackman, $1987,2002)$. The stakeholder approach to organizational performance makes a similar argument for assessing the expectations and evaluations of organizations' stakeholders, because organizations rely on them for the attainment of goals (Denison, Hooijberg, \& Quinn, 1995; Freeman \& Reed, 1983; Schneider, 2002). With regard to individual-level leadership, researchers have assessed the evaluations of followers as sources of insight in leadership effectiveness (Denison et al., 1995; Hooijberg \& Choi, 2000; Hooijberg, Hunt, \& Dodge, 1997). In line with this previous research, we assess the expectations and evaluations of TMTs' stakeholders to achieve a more comprehensive model of TMT performance.

For TMTs, an important category of intra-organizational stakeholders are middle managers (MMs), the managers who work in the layer between the TMT and first-level supervisors, as they are key actors for implementing TMTs' strategic decisions (Currie \& Procter, 2005; Dopson, Risk, \& Stewart, 1992; Floyd \& Wooldridge, 1997). MMs have been found to have the power to delay strategy implementation, reduce the quality of implementation, or even sabotage it completely (Floyd \& Wooldridge, 1997; Guth \& MacMillan, 1986; Pye, 2005). They also have a sensemaking function visà-vis their subordinates (Sims, 2003). Therefore, MMs can be seen as a particularly relevant group of stakeholders when studying TMT performance. Although not investigated here, MMs' expectations and evaluations might be consequential for outcomes related to themselves, such as their satisfaction and commitment, to the TMT, as they might give or withhold resources that can influence TMT performance, and to employees, as MMs influence sensemaking (e.g., Dirks \& Ferrin, 2002; Mayer \& Gavin, 2005). 
The specific aims of this study are: 1) to identify potential dimensions of TMT performance based on a literature review and expert interviews, 2) to test in a sample of MMs in different countries if $\mathrm{MMs}^{\prime}$ expectations and evaluations can be organized along the identified aspects of TMT performance and if this dimensionality is similar for the expectations and evaluations, and 3) to investigate if MMs' expectations and evaluations are systematically influenced by characteristics of MMs, their TMTs, or the organizations in which they work and if discrepancies exist between MMs' expectations and evaluations. In the following, we will describe the theoretical background of this study, which is based on research on TMTs and team performance, as well as on research on the role of MMs, theories of implicit leadership, and knowledge on followers' cognitions about leaders. Thereafter, we specify the research questions that guide our empirical study and present the methods and results of the study.

\section{Theoretical Background}

\section{Perspectives on TMT Performance}

Academic interest in TMTs has flourished since Hambrick and Mason's (1984) presentation of 'upper-echelons theory'. These authors argued that organizational leadership is a shared activity and that understanding the background of TMT members is of central interest for explaining strategic choice and organizational performance. Since then, a stream of research has evolved trying to link TMT composition - for example in terms of heterogeneity of age, tenure, or functional background to organizational performance (for recent reviews, see Carpenter et al., 2004; Certo, Lester, Dalton, \& Dalton, 2006). The basic assumption of upper-echelons research is that TMTs with a specific composition perform better than others and that this improved TMT performance is reflected in better organizational performance. As the vast majority of this research relies on archival data, organizational performance is typically assessed with accounting indicators, such as Return on Assets (ROA) or Return on Investment (ROI) (see, for example, laquinto \& Fredrickson, 1997; Smith et al., 1994). These measures provide aggregated performance information and have the advantage of being easily accessible and supposedly objective (Cohen \& Bailey, 1997).

Although researchers have argued that organizational performance should be the ultimate criterion for a TMT's performance, inferring TMT performance from organizational performance is problematic for conceptual and theoretical reasons. The conceptual problem is that the two constructs refer to different levels: TMT versus organization. Organizational performance is the result of a variety of factors not necessarily under control of the TMT, among which employees' efforts, competitors' behavior, the business environment, and even luck (Simons, 1996). The related theoretical problem is that models that link TMT composition to organizational performance run the risk of being underspecified. Indeed, a recent meta-analysis on the effects of TMT composition on organizational performance showed that the effects "do not hold across the TMT indicators, nor do they hold across the performance indicators; as importantly, those relationships that are significant indicate relatively modest associations between the relevant TMT indicators and firm performance" (Certo et al., 2006, p. 829). To achieve more comprehensive models of how TMT composition 
influences organizational performance, researchers have proposed to incorporate mediators and moderators in this relationship, such as conflict or communication (Carpenter et al., 2004).

We underline this reasoning and propose to take it one step further. To achieve a better insight in TMT impact on their organizations, researchers should not only theorize about new independent variables, but also critically evaluate their dependent variables. That is, by placing the focus on financial organizational performance, intermediary, more proximal indicators of TMT performance have been neglected. This is problematic, because studies that did incorporate both organizational and team-level outcomes showed that the effects of TMT composition and processes on outcomes vary with the outcomes chosen (Barrick, Bradley, Kristof-Brown, \& Colbert, 2007; Elron, 1997). Additionally, the effects of TMT composition and internal processes on organizational performance might present themselves only after a certain period of time, whereas their effects on proximal measures can be more immediate (e.g., Ancona et al., 2001). The timely monitoring of TMT performance with proximal indicators could thus function as an early-warning system so that the malfunctioning of a TMT could be detected before it translates in poor organizational performance.

A further consideration in not equating TMT to financial organizational performance only is the inherent multi-dimensional nature of TMT performance (cf., Roe, 1999). As it is likely that TMTs differ in the degree of success with which they fulfill various tasks, a focus on the outcomes of only one of these tasks leads to an incomplete picture of performance. For example, a TMT might be very good in signaling market opportunities and formulating high-quality strategic decisions, but it might do less well in ensuring the implementation of these decisions. The multi-dimensional nature of performance has been incorporated in many conceptualizations of the performance of individuals, teams and organizations.

On the individual level, researchers in the field of personnel psychology studying employee performance have pleaded for a balanced account of performance aspects (Russell, 2001). On the team level, researchers have used a variety of indicators to assess team performance and they have suggested that it is advisable to combine different indicators to get a complete picture of team performance (Cohen \& Bailey, 1997; Hackman, 1987, 2002). On the organizational level, researchers have proposed that performance can only be understood when acknowledging that it is a multidimensional construct and that dimensions might sometimes be conflicting (Cameron, 1986a, 1986b). On this level, researchers have also developed instruments such as the balanced scorecard, to measure multiple dimensions of performance simultaneously (Kaplan \& Norton, 1992, 1993).

Thus, while sophisticated performance evaluation approaches exist for individuals, nonmanagerial teams, and organizations, no comparable system can be found for TMTs. One theoretical paper exists, however, in which the authors base themselves on previous research on nonmanagerial teams (Hackman, 1987, 2002) and suggest that TMT performance can be seen as a three-dimensional construct (Edmondson, Roberto, \& Watkins, 2003). Therefore, we suggest that it is meaningful to consider multiple dimensions of TMT performance simultaneously.

\section{MMs' Expectations and Evaluations of TMT Performance}

As the starting point for establishing the dimensionality of TMT performance, we take Hackman's $(1987,2002)$ notion that the first important indicator of a team's performance is that the 
"productive output of the team (that is, its product, service, or decision) meets or exceeds the standards of quantity, quality, and timeliness of the team's clients - the people who receive, review, or use the output" (Hackman, 2002, p. 23). From a different angle, the stakeholder literature makes a similar argument on the organizational level for assessing the expectations of stakeholders, and meeting these expectations, for the optimal functioning of organizations (Cameron, 1986a; Connolly, Conlon, \& Deutsch, 1980; Freeman \& Reed, 1983; Schneider, 2002). As stakeholders have the power to give or withhold resources, such as information, materials, and their own efforts, which are critical for the TMT's chance to achieve its objectives (Schneider, 2002; Tsui, Ashford, Clair, \& Xin, 1995), meeting their expectations is of central importance for a TMT. We focus specifically on MMs as important stakeholders, or 'clients', of the TMT, as MMs are central in both strategy formulation and implementation.

MMs have mostly been studied with the aim of clarifying their organizational roles. For example, researchers have emphasized that MMs are not only crucial for the implementation of strategy, but can also influence strategy formulation, for example by issue-selling or synthesizing information for the TMT (Currie \& Procter, 2005; Dutton, Ashford, O'Neill, Hayes, \& Wierba, 1997; Floyd \& Wooldridge, 1992, 1997). They have also described how MMs have both upward and downward influence, and designated MMs as 'linking pins' in organizations (Floyd \& Wooldridge, 1992, 1997). With this role as linking pins, MMs make sense of what happens in the organization for their subordinates and, thus, can influence how other people in the organization think about the TMT (Gibson \& Schroeder, 2003; Sims, 2003). That is, the sense that MMs make regarding TMT performance feeds into the processes of their employees' speculating and talking about how top management is doing its job. This way, MMs can also influence the trust that their subordinates have in the TMT, which has been found to be related to employees' job performance, organizational citizenship behavior, job satisfaction, and commitment (Dirks \& Ferrin, 2002; Mayer \& Gavin, 2005; Simons, 2002). Thus, top managers depend on MMs to achieve organizational goals and have to find ways to gain MMs' commitment or, at least, compliance for their course of action.

For individual-level leadership, researchers have argued that leaders and managers should increase their awareness of how subordinates think about their performance, because they depend on them for the attainment of goals (Boal \& Hooijberg, 2000; Hooijberg \& Choi, 2000). This research also shows that subordinates have clear expectations for their managers (Hooijberg \& Choi, 2000). Along the same line, we propose that MMs will have expectations about their TMT and that they are inclined to evaluate their TMT's performance ${ }^{1}$.

A large-scale assessment of subordinates' cognitions about leadership was reported in the GLOBE study, in which respondents from different countries participated. In this research program, researchers were interested in assessing respondents' perceptions of 'current practices of leadership'

\footnotetext{
${ }^{1}$ We assume in this study that the TMT in an organization exists as a social entity and MMs can perceive it as such. Although the meaning of 'team' in TMT is sometimes considered to be ambiguous, and scholars have used various conceptualizations and measures to identify the TMTs under study (Certo et al., 2006; Cohen \& Bailey, 1997), it seems that organizations increasingly rely on real teams at the top (Wageman, Nunes, Burruss, \& Hackman, 2008; Yukl, 2006). Moreover, since research has shown that the TMT in the European two-tier system is more distinguishable as a distinct social entity ('executive board of directors') than TMTs in the Angelo-Saxon one-tier system (Glunk, Heijltjes, \& Olie, 2001) and since our research took place among MMs in European countries, this assumption seems warranted for our data.
} 
and their 'ideal practices of leadership' (Den Hartog, House, Hanges, Ruiz-Quintanilla, \& Dorfman, 1999; Dickson, Resick, \& Hanges, 2006; Hanges \& Dickson, 2004). This way, the researchers could get insight in potential discrepancies between actual and idealized leadership and assess the consequences of such discrepancies. In line with this approach, we were interested in two types of cognitions from MMs: their expectations and evaluations, which we see as two types of cognitions with different temporal foci.

Expectations are cognitive structures that an individual can hold about future activities and are, in an organizational setting, often associated with the occupancy of a certain organizational role (Katz \& Kahn, 1978). As such, they capture a future, and possibly idealized, situation. MMs are likely to hold expectations for their TMT based on the TMT's role at the top of the organization. Researchers have studied such expectations of leadership under the headings of 'implicit leadership theories' (Den Hartog et al., 1999; Keller, 2003), 'effectiveness models' (Hooijberg \& Choi, 2000) and 'cognitive prototypes of effective leadership' (Dickson et al., 2006). Previous work on these constructs has shown that employees' expectations of leadership have consequences for their perceptions of their leaders, as well as for their attitudes and behavior (Epitropaki \& Martin, 2005; Weick, 1995).

Evaluations are also cognitive structures, but they have a focus on past activities instead of future ones and capture MMs' subjective assessments of actual behavior of the TMT. They typically include some notion of 'cause' or 'responsibility'. That is, there is a normative dimension involved in an evaluation, as an action or entity is measured against a standard. Social psychological research on attribution processes has shown that individuals in almost all situations are motivated to form evaluations as they search for causes of events and assign responsibility for the outcomes of events (Brehm, Kassin, \& Fein, 1999; Malle \& Knobe, 1997; Martinko, Harvey, \& Douglas, 2007). In organizations, the actions of top managers, because these managers are authority figures that are highly visible in their role at the top of the organization, are particularly prone to be the focal concept of evaluative processes (Gibson \& Schroeder, 2003). Once evaluations are formed, their effects on people's thinking and acting are pervasive and subsequent attributions tend to be consistent with people's initial explanations (Anderson, Lepper, \& Ross, 1980). This way, evaluations and expectations can influence and reinforce each other.

In sum, we propose that assessing MMs' expectations and evaluations provides a meaningful way to achieve a comprehensive model of TMT performance. This is because team performance should be assessed from the perspective of stakeholders (Hackman, 1987, 2002) and because MMs are important stakeholders of a TMT. As performance on individual, team and organizational levels has been acknowledged to be multi-dimensional, we propose that this is likely to be the case for TMT performance as well. In the following, we will identify aspects of TMT performance from previous research and complement these with our findings from interviews with TMT members and others. These aspects will form the base for testing the dimensionality of TMT performance among MMs.

\section{Identification of TMT Performance Aspects}

To identify aspects of TMT performance that could be incorporated in our model, we performed a literature review of TMT research and identified dimensions of TMT performance. Since 
much of the existing TMT research had focused on financial measures of organizational performance, we also broadened our scope to the literature on nonmanagerial teams. To be included in our conceptualization, we selected the aspects present in previous studies against the criterion that they should be usable in a stakeholder measure of TMT performance. We also sought to obtain a set of dimensions that would apply to MMs, but at the same time could later serve as a base from which other stakeholders could assess TMT performance.

In addition to using existing studies on TMTs and nonmanagerial teams, we performed semistructured interviews with managers and Human Resources (HR) professionals. These interviews aimed to capture aspects of TMT performance that were emphasized by experts from practice, which could inform our selection and measurement of the dimensions. Interviews were conducted with four top executives (i.e., functioning in a TMT), two former top executives (i.e., previously functioning in a TMT and now retired) and three HR professionals from different large organizations. During the interviews, we were interested in performance criteria for TMT work, as well as more generally in TMT functioning, and our questions to the interviewees followed these two broad themes. The interviews lasted between 30 minutes and 2 hours and were tape recorded with the consent of the interviewees. The verbatim transcripts of the interviews were content analyzed by two researchers, one of whom had also been the interviewer. The coders independently listed and categorized all aspects of TMT performance that were mentioned during the interviews. Aspects of TMT performance surfaced during all interviews. Combining the results from the interviews and the literature review, we came to six aspects of TMT performance that will be further outlined below: company results, strategic leadership, connectedness, TMT unity, moral leadership, and learning capacity.

In line with most existing research on TMTs, the first aspect of TMT performance that we identified was 'company results' (Carpenter et al., 2004; Certo et al., 2006; Hambrick \& Mason, 1984). This aspect is defined as the overall outcomes of the organization expressed in financial indicators and in the degree to which the organization has reached its goals. The interviewees also mentioned the importance of organizational performance for assessing how well a TMT is performing. Thus, as argued before, although organizational performance should not be the only outcome along which TMT performance is assessed, we did include it as one of the six aspects in our model.

The second aspect is 'strategic leadership', representing the main duty of the TMT: carrying the responsibility for making and implementing strategic decisions that contribute to the overall success of the organization (Boal \& Hooijberg, 2000; Edmondson et al., 2003). Strategic leadership activities comprise, for example, making strategic decisions, creating and communicating a vision for the future, developing organizational structures, and managing multiple constituencies (Boal \& Hooijberg, 2000). In previous TMT research, 'strategic leadership' was often represented by its outcomes when researchers assessed strategic decision quality or TMT members' commitment to strategic decision implementation (for example, Amason, 1996; Dooley \& Fryxell, 1999).

The third aspect represents the extent to which the TMT develops and maintains relationships to other intra- and extra-organizational actors (Collins \& Clark, 2003; Finkelstein \& Hambrick, 1996; Mintzberg, 1973), which we have labeled 'connectedness'. For top managers, it is an essential part of their work to be connected to others in their environment both inside and outside their organization. 
Therefore, the quality, quantity, and diversity of the contacts and network of the TMT is proposed to be an aspect of its performance (Ancona, 1989; Carmeli \& Tishler, 2006; Collins \& Clark, 2003).

Then, we identified 'TMT unity', the extent to which the TMT acts as a team toward others, as a fourth aspect of TMT performance. More specifically, TMT unity is the degree to which TMT members coordinate their actions toward others in such a way that the TMT is perceived by others as a unified whole (Raes, Glunk, Heijltjes, \& Roe, 2007; see also chapter 4). This also relates to the concept of 'TMT collective action', which researchers have previously described as the capability of the TMT to take collective action despite holding differences of opinion (Jarzabkowski \& Searle, 2004, p. 405). TMT unity is different from concepts that describe the extent to which TMT members internally agree with each other, such as agreement seeking or strategic consensus (Knight et al., 1999), as TMT unity toward others outside the team can be present, at least theoretically, even when TMT members internally disagree. TMT unity is an aspect of TMT performance, because it captures the specific demands of having a team in place at the top for its leadership task instead of a single individual.

Fifth, there is the aspect of 'moral leadership', defined as the alignment between a TMT's words and deeds while influencing others to achieve shared objectives, as perceived by MMs (Simons, 2002). Our aspect of 'moral leadership' closely aligns to the concept of integrity, which is typically associated with honesty, consistency, and the adherence to moral principles (Parry \& ProctorThomson, 2002; Worden, 2003) and behavioral integrity, which the perceived pattern of alignment between a manager's words and deeds (Davis \& Rothstein, 2006; Simons, 2002). However, we included 'leadership' in formulating this aspect to refer to the domain in which integrity is exercised, namely in influencing others to achieve shared objectives (e.g., Yukl, 2006).

The final aspect that we identified is 'TMT learning capacity', the degree to which the TMT demonstrates its ability to learn from its experiences. Prior research has illustrated that a moderate amount of learning in management teams leads to increased team performance (Bunderson \& Sutcliffe, 2003). Research on nonmanagerial teams has also outlined the role of team learning as beneficial for team performance (Edmondson, 1999). Although previous research has addressed team learning as a determinant of performance rather than as an indicator for it, we wanted to test if the demonstration of learning might also be something that MMs see as an aspect of TMT performance.

\section{Research Questions}

We have proposed that MMs have expectations about their TMT and are inclined to evaluate it, and we identified six aspects of TMT performance. Now, we are interested to see whether MMs' expectations and evaluations can be organized along these aspects. We assume that such expectations and evaluations are important, not only because they influence MMs' readiness to execute the TMT's decisions, but also because they can influence the attitudes and behavior of MMs' subordinates towards the TMT, the decisions of the TMT, and even to the organization in general. Although the importance of assessing expectations and evaluations has been shown for individual-level leadership (Denison et al., 1995; Hooijberg \& Choi, 2000; Schneider, 2002), this issue has never been explored in the context of TMT performance and MMs. Thus, our first research question is: Can the aspects of 
company results, strategic leadership, connectedness, TMT unity, moral leadership, and TMT learning capacity be identified as dimensions of TMT performance in the expectations and evaluations of MMs?

Based on attribution theories and implicit-leadership theory (Epitropaki \& Martin, 2005; Keller, 2003; Simons, 2002), we expect that MMs' perceptions of TMT performance might vary as a function of characteristics of the MMs, TMT, and organization. For instance, there may be divergence in ratings due to differences in characteristics of the MMs themselves, such as gender and work experience (Martinko et al., 2007). Similarly, because the role of TMTs in smaller and larger organizations is different, MMs in various organizations may vary in the aspects of TMT performance they emphasize (Martinko et al., 2007). Additionally, there might also be cultural and national differences that influence the cognitions of MMs in different countries. The research on TMTs until now has predominantly used data from North American organizations, which recently led Hambrick (2007) to plead for supplementing this US-based knowledge with an international perspective. Previous research has pointed at country- and culture-related differences in work values (Hofstede, 2001), leadership preferences (Dickson, Den Hartog, \& Mitchelson, 2003), the meaning of 'teamwork' (Gibson \& Zellmer-Bruhn, 2001), and the composition and functioning of TMTs (Glunk et al., 2001; Peck \& Ruigrok, 2000). Therefore, we formulated a second research question: To what extent do MMs' expectations and evaluations depend on MM, TMT, and organizational characteristics, and to what extent do they differ between countries?

As implied by stakeholder theory, the extent to which managers, teams, or organizations meet the expectations of important stakeholders can influence the attainment of critical resources that these stakeholders supply (Coombs \& Gilley, 2005; Freeman \& Reed, 1983; Schneider, 2002). Research within the GLOBE project has shown that there might be discrepancies between employees' perceptions of actual and idealized leadership, which can have consequences for satisfaction and commitment (Den Hartog et al., 1999; Dickson et al., 2003; Dickson et al., 2006). Although the objective of this research was not to assess MMs' attitudes or behavior that result from their expectations and evaluations of TMT performance, we were interested in the extent to which discrepancies existed between these two types of cognitions. Therefore, our final research question is: To what extent are MMs' expectations and evaluations on the performance dimensions similar and do discrepancies exist between MMs'scores on the expectations and evaluations?

\section{Method}

\section{Sample and Data Collection}

Our sample consisted of 108 French and 143 Dutch MMs. This sample was drawn from the client pool of an international consultancy firm that included organizations from various industries and countries. In the context of the firm's annual research among its clients, taking place in March 2005, all MMs in the pool were invited to answer a web-based questionnaire on TMT performance. The questionnaire was available in four languages: English, German, French, and Dutch. In total, 2430 emails were delivered to respondents in 19 countries and 530 filled questionnaires were returned, a response rate of $22 \%$. 
To be able to make reliable comparisons, we only used data of the two countries with more than 100 respondents: France $(N=162)$ and The Netherlands $(N=188)^{2}$. We excluded respondents that reported their TMT to have fewer than three or more than ten members $(N=55)$, which is outside the range of typical TMT sizes in European organizations (Glunk et al., 2001; Heijltjes, Olie, \& Glunk, 2003). We also excluded all respondents whose job titles raised doubt regarding their position as MMs $(N=44)$, resulting in the final sample of 108 French and 143 Dutch MMs.

Table 5.1 displays the characteristics of the sample in terms of respondents' sector of operation, gender, work experience, TMT size and organizational size. More than three quarters of the respondents were male. The majority worked in either the secondary (i.e., manufacturing, chemical, energy, IT, telecom) or the tertiary sector (i.e., service, media, leisure). They came from 152 different organizations of various sizes with a maximum of 8 respondents from the same organization. MMs' work experience ranged from less than 5 to more than 20 years.

Table 5.1. Descriptive statistics of MMs, TMTs, and organizations in the sample

\begin{tabular}{|c|c|c|c|}
\hline & $\begin{array}{l}\text { Total sample } \\
(N=251)\end{array}$ & $\begin{array}{l}\text { Netherlands } \\
(N=143)\end{array}$ & $\begin{array}{l}\text { France } \\
(N=108)\end{array}$ \\
\hline \multicolumn{4}{|l|}{$M M s^{\prime}$ sector of operation $(N)$} \\
\hline Primary (agriculture, extraction of raw material) & 23 & 11 & 12 \\
\hline $\begin{array}{l}\text { Secondary (manufacturing, chemical, energy, IT, } \\
\text { telecom) }\end{array}$ & 91 & 56 & 35 \\
\hline $\begin{array}{l}\text { Tertiary (financial services, public services, } \\
\text { consulting, transport, retailing, media, leisure) }\end{array}$ & 109 & 65 & 44 \\
\hline \multicolumn{4}{|l|}{$M M s^{\prime}$ gender $(N)$} \\
\hline Male & 186 & 109 & 77 \\
\hline Female & 49 & 27 & 22 \\
\hline \multicolumn{4}{|l|}{$M M s^{\prime}$ work experience in years $(N)$} \\
\hline $0-5$ & 55 & 32 & 23 \\
\hline $6-10$ & 52 & 26 & 26 \\
\hline $11-15$ & 47 & 28 & 19 \\
\hline $16-20$ & 34 & 19 & 15 \\
\hline More than 20 & 48 & 30 & 18 \\
\hline \multicolumn{4}{|l|}{ TMT size } \\
\hline Mean & 5.89 & 5.27 & 6.71 \\
\hline Standard deviation & 2.22 & 1.87 & 2.38 \\
\hline \multicolumn{4}{|l|}{ Organizational size - number of employees $(N)$} \\
\hline $1-50$ & 16 & 11 & 5 \\
\hline $51-100$ & 30 & 21 & 9 \\
\hline $101-500$ & 54 & 30 & 24 \\
\hline $501-1000$ & 32 & 18 & 14 \\
\hline $1001-5000$ & 59 & 38 & 21 \\
\hline $5001-10000$ & 15 & 10 & 5 \\
\hline More than 10000 & 31 & 9 & 22 \\
\hline
\end{tabular}

Note. The total number respondents in sample was 251; when numbers in a category do not add up to 251 , the remaining respondents did not provide information on this category and these data were treated as missing values.

\footnotetext{
${ }^{2}$ The number of respondents for the 17 other countries varied between 1 and 48 with a mean of 10.29. The large number of respondents from France and the Netherlands reflects that the consultancy firm was most active in these countries.
} 


\section{Measures}

We wanted to assess MMs' expectations and evaluations of the TMT performance aspects to establish the dimensionality of TMT performance. Given the fact that TMT performance has to our knowledge never been assessed from MMs' - or any stakeholder's - perspective, we developed new scales to capture the TMT performance aspects 'company results', 'strategic leadership', 'connectedness', 'TMT unity', 'moral leadership', and 'TMT learning capacity'. We developed two parallel sets of items that were similar in content, but that were presented to the respondents in two different ways to measure their expectations and evaluations. Based on existing literature and the interview results, we developed three to five items for each performance aspect. An example of an item for the aspect 'company results' is: 'The company achieves outstanding financial results', for strategic leadership: 'The TMT has a clear vision of the company's future', for connectedness: 'The TMT is well-connected to important players inside the company', for learning capacity: 'The TMT develops new skills and knowledge within the team', and for moral leadership: 'The TMT brings into practice what it preaches'. In table 5.3, all items for all performance aspects are shown.

MMs' expectations and evaluations. To measure MMs' expectations, they were asked the following question: 'Suppose you were asked to judge whether the top management team of your company effectively performs its task. Which criteria would you consider important to make this judgment?' They were asked to indicate on a 5-point Likert scale, with scale anchors $1=$ totally disagree and 5 = totally agree, the extent to which they agreed with the statement that 'a top management team effectively performs its task, if [text item] ;' To measure MMs' evaluations of their TMTs' performance, respondents were asked to indicate on a 5-point Likert scale, with scale anchors $1=$ totally disagree and $5=$ totally agree, the extent to which they agreed with the statement that 'the top management team of my organization [text item];' They were also asked to report any aspect of TMT performance that they had missed in the list of items. Analyses of the answers to this open question did not give indications that we had missed an important aspect.

The final questionnaire consisted of two times 24 items, which were shuffled and presented to the respondents. As TMT researchers have used varying definitions of the TMT in their studies (Certo et al., 2006), we presented MMs the following definition of a TMT: 'The term "top management team" stands for the group of people who are responsible for the general course of the company; usually these are the CEO and several executive directors. Depending on your national background, you might be more familiar with the terms Executive Board, Vorstand, Comité de Direction, or Raad van Bestuur.'

MM, TMT, and organizational characteristics. As characteristics of MMs, we asked respondents to indicate their gender and years of work experience. For TMT characteristics, we asked respondents to indicate the number of TMT members in their organization as a measure of TMT size. Finally, we asked respondents to report the number of employees in their organization as a measure for organizational size and we asked them to indicate the sector in which they were working. This variable 'sector' was later coded as primary (agriculture, extraction of raw material), secondary (manufacturing, chemical, energy, IT, telecom), or tertiary (financial services, public services, consulting, transport, retailing, media, leisure). 


\section{Data Analysis}

The data obtained for MMs' expectations and evaluations in two countries resulted in four data sets: expectations-Netherlands, expectations-France, evaluations-Netherlands, evaluations-France. Our data-analysis approach consisted of several steps, which followed the order of the research questions. First, we performed exploratory (EFA) and confirmatory factor analyses (CFA) to establish the dimensionality of TMT performance. In the confirmatory factor analyses equality constraints were introduced, so that we could test if the obtained expectations and evaluations models fitted the data equally well in both countries.

To answer research questions 2 and 3, we calculated expectation and evaluation scales per dimension from the separate items and established their reliabilities. We then inspected the means and standard deviations of the performance dimensions and performed multivariate analyses of variance to see if individual and organizational variables were related to differences in the expectations and evaluations of the performance dimensions and if differences existed between countries. Then, correlations were obtained between MMs' expectations and evaluations on all performance dimensions to assess the extent to which the two constructs overlapped. Finally, t-tests were used to compare the ranking of the performance dimensions for MMs' expectations and evaluations to get insight in potential discrepancies between what MMs find important and what they observe in practice.

\section{Results}

\section{The Dimensionality of TMT Performance: Exploratory Factor Analyses}

We performed exploratory principal axis factoring (abbreviated as exploratory factor analysis, or EFA) with direct oblimin oblique rotation on MMs' expectations and evaluations. Oblique rotation was chosen, because we assumed that the TMT performance dimensions would be correlated. That is, if someone perceived the TMT as performing particularly well on strategic leadership, we expected that this would be related to the evaluation of, for example, company performance. To judge items if they were good or not so good indicators of the underlying factors, we used the criterion to only keep the items that had factor loadings higher than .40 on the expected factor and cross-loadings lower than .32 on other factors (Hinkin, 1998; Tabachnick \& Fidell, 2007). Since we had multiple data sets, we set the additional criterion to keep items that showed the desired properties in at least two data sets.

EFA - step 1. The first four EFAs on the four data sets resulted in 6, 5, 5, and 4 factors respectively, with eigenvalues higher than $1^{3}$. Five items did not fulfill our criteria. Therefore, we removed from the aspect of strategic leadership the item 'the TMT takes timely decisions' and from moral leadership 'the TMT is trusted by its employees'. For the items of learning capacity, we observed that they did not load on a separate factor and all but one factor loadings were below .40 . Thus, it seemed that 'learning capacity' might theoretically be an important and distinguishable

\footnotetext{
${ }^{3}$ Full results from all EFAs are available from the first author. The total amount of variance explained can not be reported, as principal axis factoring with oblique rotation does not generate a total amount of variance.
} 
dimension of TMT performance, but that MMs could not in a consistent way relate to it. Therefore, we removed all items from learning capacity from further analyses.

EFA - step 2. In step 2, we re-ran the factor analyses with the remaining 19 items and we set the number of factors to five, representing our new theoretical model. Based on the same criteria as outlined before, we deleted two more items that did not show factor loadings higher than .40 on the expected factor or had cross-loadings on other factors higher than .32. These were 'the TMT takes decisions that contribute to the company's performance' and 'the TMT dares to take risky decisions', both from strategic leadership. In the final EFAs with 17 items, Kaiser's measures of sampling adequacy ranged from .86 to .90 , indicating that the sample sizes relative to the number of items were appropriate for factor analyses procedures (Tabachnick \& Fidell, 2007). Furthermore, the tables of reproduced correlations indicated that between 12 and $16 \%$ non-redundant residuals $(p>0.05)$ existed between the observed and the reproduced correlations, suggesting an adequate fit of this 5factor model to the data. The factor structure was further tested in confirmatory factor analyses.

\section{The Dimensionality of TMT Performance: Confirmatory Factor Analyses}

CFA - expectations. To test if the hypothesized factor structure for the remaining 17 items and 5 latent factors provided a good fit to the expectations data from France and the Netherlands, we performed a multi-group confirmatory factor analysis using Lisrel version 8.72. Following Byrne's (1998) guidelines, we specified a structural model with the five performance dimensions as latent variables and the items per dimension as the observed variables. We only allowed the observed variables to load on the pre-defined associated latent construct and we set the value of the first item for each latent construct to 1 for scaling purposes. We also introduced equality constraints, requiring a solution in which the factor loadings would be identical in both countries. This model was fitted to MMs' response data for France and the Netherlands. For the data from France, 3 cases were deleted because they contained at least 1 missing value, and for the data for the Netherlands, 4 such cases were deleted. Thus, in subsequent analyses, the sample size for France was 105 and for the Netherlands 139.

Overall, the 5 -factor model showed a good fit to the data $\left(\chi^{2}(230, N=244)=332.03, p<\right.$ 0.00 , RMSEA $=0.06, \mathrm{NNFI}=0.97$ ). When inspecting the fit indexes for both countries separately, it became clear that, although the model fitted well for both countries, the fit was better for the Netherlands than for France: contribution to chi-square from the Netherlands $=131.57(37.95 \%$, and SRMR Netherlands $=0.06$; contribution to chi-square from France $=215.15(62.05 \%$, and SRMR France $=0.09$. For the overall model, the RMSEA was with 0.06 below the upper limit of 0.08 and $\mathrm{NNFI}$ exceeded the threshold of 0.90 (Vandenberg \& Lance, 2000). For the Netherlands, a value of SRMR $=0.06$ indicates an excellent fit, whereas SRMR $=0.09$ for France is acceptable as it is below the upper limit of 0.10 (Vandenberg \& Lance, 2000).

CFA - evaluations. We followed the same procedure for establishing the factor structure for the data about MMs' evaluations of their TMT's performance. First, we deleted all cases that had at least one missing value. For the Netherlands, we removed 41 respondents, and for France 28 respondents. Multivariate analyses did not show differences in characteristics of the respondents - in terms of gender, work experience, TMT size, organizational size, and industry - between these 
respondents and those remaining in the sample, nor in their scores on the performance dimensions. Thus, our samples for these analyses consisted of 89 Dutch and 75 French MMs.

The results showed that the five-factor model fitted the data about evaluations less well than the previously analyzed expectations data $\left(\chi^{2}(230, N=164)=379.80, p<0.00, \mathrm{RMSEA}=0.09\right.$, $N N F I=0.96)$. The RMSEA was with 0.09 above the upper limit of 0.08 , but the NNFI exceeded the minimum value of good fit of 0.90 (Vandenberg \& Lance, 2000). Inspection of the fit indexes for the countries separately again showed that the model fitted better for the Netherlands than for France: contribution to chi-square from the Netherlands $=157.29(40.56 \%$, and SRMR Netherlands = 0.07; contribution to chi-square from France $=230.47(59.44 \%$, and SRMR France $=0.09$. For the Netherlands, the value of SRMR $=0.07$ indicated a good fit, whereas SRMR $=0.09$ for France indicated an adequate fit, being below the upper limit of 0.10 (Vandenberg \& Lance, 2000).

CFA - alternative models. Since the fit indexes showed some ambiguity for the evaluations data, we tested alternative models to see if these would better describe the data. First, since moral and strategic leadership had loaded on one factor in step 2 of the exploratory factor analyses, we specified a model with four factors in which moral and strategic leadership loaded together on one factor. Furthermore, since the scree-plots of the exploratory factor analyses had shown a sharp decrease after the first factor, we tested if the TMT performance dimensions were better represented as a single-factor model and we performed analyses in which all items loaded on one latent factor. Finally, we tested a second-order factor model in which the five performance dimensions loaded on a second-order latent construct, which we called 'overall TMT performance'. Table 5.2 displays the fit indexes for all models.

Table 5.2. Fit indexes for 5-, 4-, 1-, and second-order factor confirmatory factor analysis models

\begin{tabular}{|c|c|c|c|c|c|c|c|}
\hline Model & $\chi^{2}$ & $d f$ & $\Delta \chi_{(\Delta d f)}^{2}$ & RMSEA & NNFI & $\underset{\mathrm{NL}^{3}}{\mathrm{SRMR}}$ & $\begin{array}{l}\text { SRMR } \\
\text { France }\end{array}$ \\
\hline \multicolumn{8}{|l|}{ Expectations } \\
\hline Model A (5-factor) & 332.03 & 230 & & 0.06 & 0.97 & 0.06 & 0.09 \\
\hline Model B (4-factor) & 472.52 & 239 & $140.49_{(9)} * *$ & 0.09 & 0.95 & 0.07 & 0.10 \\
\hline Model C (1-factor) & 802.84 & 254 & $470.81_{(24)} * *$ & 0.13 & 0.89 & 0.10 & 0.12 \\
\hline $\begin{array}{l}\text { Model D (second- } \\
\text { order model) }{ }^{1}\end{array}$ & 360.41 & 245 & $28.38_{(15)}{ }^{*}$ & 0.06 & 0.97 & 0.08 & 0.11 \\
\hline \multicolumn{8}{|l|}{ Evaluations } \\
\hline Model A (5-factor) & 379.80 & 230 & & 0.09 & 0.96 & 0.07 & 0.09 \\
\hline Model B (4-factor) & 452.81 & 239 & $73.01_{(9)} * *$ & 0.11 & 0.95 & 0.08 & 0.09 \\
\hline Model C (1-factor) & 727.54 & 254 & $347.74_{(24)} * *$ & 0.15 & 0.90 & 0.10 & 0.12 \\
\hline $\begin{array}{l}\text { Model D (second- } \\
\text { order model) }^{1}\end{array}$ & 397.96 & 245 & $18.16_{(15)}$ & 0.09 & 0.96 & 0.09 & 0.11 \\
\hline
\end{tabular}

${ }^{1}$ In model $D$, the 5 performance dimension were modeled to load on a second-order latent construct

${ }^{2} \Delta \chi^{2}$ and $\Delta_{d f}$ values report the difference in $\chi^{2}$ between the reported model and model $\mathrm{A}$

${ }^{3} \mathrm{NL}=$ Netherlands

Notes. Expectations: $N_{\text {Netherlands }}=139$ and $N_{\text {france }}=105$; Evaluations: $N_{\text {Netherlands }}=89$ and $N_{\text {france }}=75$; Model A: full model with 18 items and 5 factors; Model B: moral and strategic leadership items together on one factor; Model C: all items on one factor; Model D: 5-factor model with all factors loading on one secondorder factor; The reported indexes are the global fit indexes that indicate overall model-fit to the data from France and the Netherlands; All analyses were performed with equality constraints for the data from the two countries; $* p<.05 ; * * p<.01$ 
When subsequent models are nested in the original model, the difference in chi-square in combination with the change in degrees of freedom between the models can be seen as an indication of a better or worse fit of alternative models (Byrne, 1998). Based on this assessment, the results indicated that the 4-factor (expectations: $\Delta \chi^{2}{ }_{(\Delta d f)}=140.49_{(9),} p<.01$; evaluations: $\Delta \chi_{(\Delta d f)}^{2}=73.01_{(9),} p$ $<.01)$ and the 1 -factor (expectations: $\Delta \chi_{(\Delta d f)}^{2}=470.81_{(24)}, p<.01$; evaluations: $\Delta \chi_{(\Delta d f)}^{2}=347.74_{(24),} p$ $<.01)$ models showed a significantly worse fit than the 5 -factor model in both data sets. The secondorder model showed a significantly worse fit than the 5 -factor model in the expectations data ( $\Delta \chi^{2}(\Delta d f$ $\left.=28.38_{(15),} p<.05\right)$, but not in the evaluations data $\left(\Delta \chi_{(\Delta d f)}^{2}=18.16_{(15),} p=\right.$ n. s.).

These analyses confirmed what we had suspected from theory and exploratory factor analyses, that TMT performance from the perspective of MMs can be seen as a multi-dimensional construct and that moral and strategic leadership are best conceptualized as distinct dimensions. Additionally, since the inclusion of a second-order factor did not provide a better fit of the model, while fitting less well to our theoretical rationale of correlated, but separate dimensions of TMT performance, we concluded from testing the alternative models that a five-factor model of TMT performance provided the best way to describe the data. In the five-factor model, the RMSEA value for the evaluations data was higher than desirable, but the other fit statistics for these data were satisfactorily (Vandenberg \& Lance, 2000). Additionally, since we had imposed strong restrictions on our model, i.e., equality constraints for both countries and no allowance of cross-loadings or correlated errors, we decided that the model can be seen as acceptable for these data. Table 5.3 displays the factor loadings of the items on the five dimensions in the four data sets.

\section{Middle Manager, TMT, Organizational, and Country Differences}

Having established the dimensionality of TMT performance, we proceeded towards research question 2, in which we were interested in how MM, TMT, organizational, and country differences contributed to differences in expectations and evaluations. Therefore, we first assessed the internal consistency of the scales for each construct by calculating Cronbach's alpha's. For all dimensions, we obtained good Cronbach's alpha's that ranged between .74 and .90, and we concluded that the items could be combined to single scores for the expectations and evaluations on every performance dimension. We calculated the means of the item scores as scale scores for every respondent. The means, standard deviations, and Cronbach's alpha's of the expectations and evaluations dimensions are depicted in table 5.4 .

Subsequently, we performed separate multivariate analyses of variance (MANOVA) for the two data sets with the five performance dimensions as dependent variables. For both MANOVA's, the independent variables were gender, sector (primary, secondary, tertiary), and country (France, Netherlands) and we included as covariates organizational size, TMT size, and years of work experience. We also included interaction terms for sector, organizational size, TMT size, and years of work experience with country to see if the effects of these variables differed per country.

In the expectations data, the results showed no significant multivariate effects for the independent variables and covariates. Thus, MMs' expectations on the various dimensions of TMT performance were unrelated to their gender, work experience, to the size of their TMT or organization, or to the country in which they worked. Also for the evaluations, no significant 
multivariate effects were found. Thus, in response to research question 2, no differences in MMs expectations and evaluations were found across countries, sectors of operation, MMs' gender and work experience, and TMT and organizational size.

Table 5.3. Standardized factor loadings of scale items per dimension of TMT performance from confirmatory factor analyses, and items deleted after exploratory factor analyses

\begin{tabular}{|c|c|c|c|c|}
\hline & \multicolumn{2}{|c|}{$\begin{array}{l}\text { Factor loadings } \\
\text { Expectations }\end{array}$} & \multicolumn{2}{|c|}{$\begin{array}{l}\text { Factor loadings } \\
\text { Evaluations }\end{array}$} \\
\hline & $\mathrm{NL}^{1}$ & France & NL & France \\
\hline \multicolumn{5}{|l|}{ Company results } \\
\hline the company's viability is secured & .83 & .67 & .82 & .84 \\
\hline the company meets its strategic goals & .76 & .73 & .86 & .88 \\
\hline the company is ahead of competition & .65 & .59 & .68 & .58 \\
\hline the company achieves outstanding financial results & .49 & .47 & .66 & .62 \\
\hline \multicolumn{5}{|l|}{ Strategic leadership } \\
\hline the TMT has a clear vision of the company's future & .84 & .85 & .73 & .81 \\
\hline it takes decisions in line with a defined strategy & .78 & .86 & .82 & .91 \\
\hline it sets measurable company goals & .68 & .73 & .65 & .72 \\
\hline \multicolumn{5}{|l|}{ Connectedness } \\
\hline $\begin{array}{l}\text { it is well-connected to important players inside the } \\
\text { company }\end{array}$ & .65 & .85 & .62 & .77 \\
\hline it is well-connected to the external world & .69 & .85 & .76 & .77 \\
\hline it can count on an external support network & .51 & .66 & .80 & .84 \\
\hline \multicolumn{5}{|l|}{ TMT unity } \\
\hline it acts as a team & .89 & .83 & .94 & .90 \\
\hline it has a shared view on the future & .71 & .69 & .87 & .86 \\
\hline it speaks with one voice & .67 & .58 & .81 & .83 \\
\hline it takes decisions collectively & .71 & .67 & .68 & .65 \\
\hline \multicolumn{5}{|l|}{ Moral leadership } \\
\hline it brings into practice what it preaches & .85 & .85 & .87 & .86 \\
\hline it acts with a high level of integrity & .77 & .79 & .77 & .84 \\
\hline it serves as an example for others & .76 & .87 & .86 & .89 \\
\hline \multicolumn{5}{|l|}{ Items deleted after exploratory factor analyses } \\
\hline \multicolumn{5}{|c|}{$\begin{array}{l}\text { it takes decisions that contribute to the company's performance - strates } \\
\text { it takes timely decisions - strategic leadership } \\
\text { it dares to take risky decisions - strategic leadership } \\
\text { it is trusted by its employees - moral leadership } \\
\text { it learns from mistakes - learning capacity } \\
\text { it evaluates the outcomes of decisions taken - learning capacity } \\
\text { it develops new skills and knowledge within the team - learning capacity }\end{array}$} \\
\hline
\end{tabular}


Table 5.4. Means, standard deviations, Cronbach's alpha's, and Pearson correlations of MMs' expectations and evaluations on five dimensions of TMT performance

\begin{tabular}{|c|c|c|c|c|c|c|c|c|c|c|c|c|}
\hline & $M$ & $S D$ & $\begin{array}{l}\text { Cronbach's } \\
\text { alpha }\end{array}$ & 1 & 2 & 3 & 4 & 5 & 6 & 7 & 8 & 9 \\
\hline \multicolumn{13}{|l|}{ Expectations } \\
\hline 1. Company results & 3.90 & .68 & .76 & & & & & & & & & \\
\hline 2. Strategic leadership & 4.27 & .73 & .81 & $.47^{* *}$ & & & & & & & & \\
\hline 3. Connectedness & 3.92 & .73 & .74 & $.43^{* *}$ & $.54 * *$ & & & & & & & \\
\hline 4. TMT unity & 4.05 & .70 & .81 & $.50 * *$ & $.49 * *$ & $.42 * *$ & & & & & & \\
\hline $\begin{array}{l}\text { 5. Moral leadership } \\
\text { Evaluations }\end{array}$ & 4.32 & .74 & .84 & $.42 * *$ & $.60 * *$ & $.48 * *$ & $.58 * *$ & & & & & \\
\hline 6. Company results & 3.38 & .83 & .83 & .05 & .09 & .04 & .04 & .12 & & & & \\
\hline 7. Strategic leadership & 3.37 & .87 & .78 & .04 & .12 & -.01 & .01 & .03 & $.54 * *$ & & & \\
\hline 8. Connectedness & 3.37 & .86 & .78 & .04 & .04 & .01 & .04 & .12 & $.57 * *$ & $.52 * *$ & & \\
\hline 9. TMT unity & 3.20 & .93 & .89 & $.18^{* *}$ & $.15^{*}$ & .09 & .09 & $.15^{*}$ & $.57 * *$ & $.54 * *$ & $.54 * *$ & \\
\hline 10. Moral leadership & 3.27 & .99 & .90 & .05 & .06 & -.04 & .05 & .03 & $.57^{* *}$ & $.63 * *$ & $.60 * *$ & $.61^{* *}$ \\
\hline
\end{tabular}

Notes. $N_{\text {expectations }}=251$ and $N_{\text {evaluations }}=233 ; M=$ mean, $S D=$ standard deviation; $* p<.05 * * p<.01$ 


\section{To What Extent Are MMs' Expectations and Evaluations Similar and Are There Discrepancies in MMs' scores?}

With the dimensionality of the TMT performance aspects established, we were interested in assessing the extent to which MMs' expectations and evaluations were similar and to what extent discrepancies existed between their expectations and their evaluations - as formulated in research question 3. To answer this question, we first calculated the correlations between MMs' expectations and evaluations on all performance dimensions. If the correlation between $\mathrm{MMs}^{\prime}$ expectations and evaluations of, for example, moral leadership would be high, we would conclude that these two types of cognitions are related and that it might be difficult to make a distinction between them. If the correlations would be low, this would indicate that they were separate constructs and that it would be meaningful to assess if discrepancies existed between $\mathrm{MMs}^{\prime}$ scores on the expectations and evaluations. Second, we compared the relative importance of the performance dimensions to see whether the ranking would be similar or different for the expectations and evaluations.

Correlations. The correlations between every pair of dimensions for expectations and evaluations are depicted in table 5.4. These results show that the correlations between the evaluations and expectations on the same performance dimension were very low to moderate, ranging from .01 to .18 and only three out of 25 correlations were significant. The significant correlations showed a positive association between MMs' evaluations of TMT unity and their expectations of company results, strategic leadership, and moral leadership. In contrast, the correlations between the TMT performance dimensions within the expectations and within the evaluations data ranged between .42 and .63 and were all significant with $p<.01$. Thus, although the underlying dimensionality of TMT performance is similar for MMs' expectations and evaluations of TMT performance, the two types of cognitions do represent different and almost uncorrelated constructs.

Ranking of the dimensions. Table 5.4 also depicts the mean levels of MMs' expectations and evaluations on each performance dimension. To test if the mean scores among the dimensions for expectations and evaluations were significantly different, we performed t-tests between every pair of dimensions in both data sets. MMs' expectations were highest for the dimensions of moral leadership $\left(M_{\text {moral leadership }}=4.32\right)$ and strategic leadership $\left(M_{\text {strategic leadership }}=4.27\right)$, and these two dimensions did not significantly differ from each other. Expectations for TMT unity $\left(M_{\mathrm{TMT}}\right.$ unity $=4.05$ ) were significantly lower than those for strategic leadership $(t=4.70, p<.01)$, but higher than for connectedness ( $\left.M_{\text {connectedness }}=3.92, t=-2.78, p<.01\right)$. Connectedness and company results ( $M_{\text {company }}$ results $=3.90)$ did not differ from each other.

For the evaluations data, company results $\left(M_{\text {company results }}=3.38\right)$, strategic leadership $\left(M_{\text {strategic }}\right.$ leadership $=3.37$ ), and connectedness scored highest $\left(M_{\text {connectedness }}=3.37\right)$ and did not differ significantly. MMs evaluated their TMT lowest on moral leadership ( $\left.M_{\text {moral leadership }}=3.27\right)$ and TMT unity $\left(M_{\text {TMT }}\right.$ unity $=$ 3.20), and these dimensions did not differ significantly. The remaining t-tests showed that evaluations of company results were significantly higher than those for moral leadership $(t=2.02, p$ $<.05)$ and TMT unity $(t=3.20, p<.01)$, and that evaluations of TMT unity were also significantly lower than those for strategic leadership $(t=2.62, p<.01)$ and connectedness $(t=2.85, p<.01)$. All other differences were not significant. 
Thus, the relative order of the dimensions is not identical for the expectations and evaluations. Particularly interesting in this ranking is the reverse order of company results and moral leadership across the two types of cognitions. Whereas MMs have the highest expectations for TMT moral leadership and strategic leadership and the lowest for company results and connectedness, they evaluate TMTs highest on company results and lowest on moral leadership and TMT unity. Thus, there seems to be a discrepancy between MMs' relatively high expectations regarding moral leadership from their TMT, and their relatively low evaluations of their TMT on this dimension. On the other hand, they find company performance a relatively unimportant aspect of TMT performance, but they evaluate their TMT to perform particularly well on this dimension.

\section{Discussion}

In this study, we sought to obtain insight in the dimensionality of TMT performance as perceived by middle managers. We analyzed MMs' expectations and evaluations of their TMT and found a similar underlying structure of TMT performance dimensions in both types of cognitions, consisting of company results, strategic leadership, TMT unity, connectedness, and moral leadership. Despite this similar structure, expectations and evaluations were only weakly correlated and discrepancies could be observed between what the French and Dutch MMs expected from their TMT and what they observed. The results and implications of this study will now be discussed in more detail.

Between the evaluations and expectations on the five dimensions, low to moderate correlations were found, suggesting that $\mathrm{MMs}^{\prime}$ expectations and evaluations were different constructs. Research on cognition and perception indicates that biases of availability might colour people's perceptions and experiences (Martinko et al., 2007; Tversky \& Kahneman, 1974) and that such cognitive biases can lead to a focal construct getting more salient. Thus, MMs' expectations of TMT performance could have coloured their evaluations of it. However, whereas relatively high correlations were found between the dimensions for either the expectations or the evaluations, the correlations between the expectations and evaluations dimensions were low and almost none was significant. Thus, these two types of cognitions about TMT performance are clearly different constructs.

In this respect, the observed discrepancy between MMs' high expectations of TMT moral leadership and their relatively low evaluations of it, are intriguing. The relevance of moral leadership and perceptions of integrity of management for individual outcomes have been found in previous studies (Dirks \& Ferrin, 2002; Mayer \& Gavin, 2005). These studies have shown that employees' perceptions of top management integrity are positively related to satisfaction, commitment, and organizational citizenship behavior and negatively to intentions to quit their job (Dirks \& Ferrin, 2002; Mayer \& Gavin, 2005). In contrast, perceptions of non-integrity have been related to reduced TMT credibility, employees' disenchantment (Cha \& Edmondson, 2006), reduced support (Tsui et al., 1995), and counter-productive behavior (Brown \& Treviño, 2006; Mayer \& Gavin, 2005). Given our results on discrepancies and prior research on the potential effects on such discrepancies, more research is clearly warranted to further explore the determinants and consequences of $\mathrm{MMS}^{\prime}$ cognitions on moral leadership. 
Previous research had suggested that differences in implicit leadership theories (Keller, 2003) and attributions of TMT outcomes (Gibson \& Schroeder, 2003; Malle \& Knobe, 1997) could have led to differences in MMs' expectations and evaluations. Yet, TMT size, organizational size, MMs' gender and years of work experience were not associated with such differences. The absence of country effects in the two culturally distinct settings of France and the Netherlands (Brodbeck et al., 2000; Hofstede, 2001; Ronen \& Shenkar, 1985), is also noteworthy in this respect. These results are a first indication that this model of TMT performance might apply to MMs with various demographic characteristics, working in organizations from different sizes, and in different countries.

Initially, the aspect of 'learning capacity' was also identified as a potential dimension of TMT performance, yet, it could not be established as such in the factor analyses. Although previous research has associated this dimension with team effectiveness (Bunderson \& Sutcliffe, 2003; Edmondson, 1999), MMs in our sample could not in a consistent way relate to it as a dimension of TMT performance. As we suggested earlier, learning capacity might be a dimension that can only be judged by TMT members internally and is not so easily visible to outsiders.

\section{Contributions and Implications of the Study}

Although previous research on the individual, team, and organizational level had conceptualized performance as a multi-dimensional construct (Cameron, 1986b; Cohen \& Bailey, 1997), no such model existed for TMT performance. Yet, based on the variety of measures that previous research had used as indicators for TMT performance and the complexity and multidimensionality of the TMT task, we reasoned that also TMT performance should be conceptualized as a multi-dimensional construct. Although most upper-echelons researchers have focused on financial measures of the organizations as performance indicators, our literature review and interview results revealed the existence of several other relevant aspects. By developing measurement scales and by testing these in a series of exploratory and confirmatory factor analyses, we have established a model for evaluating TMT performance that goes beyond financial indicators. Although our main interest was in the group of MMs, this instrument might be used by other stakeholders as well, provided that they are close enough to the TMT to observe outcomes of the TMT's work.

The establishment of TMT performance dimensions in this study provides insight for at least three areas of research. First, the study enriches TMT research by contributing to the specification of more detailed models on the effects of TMT composition and TMT internal processes on various dimensions of TMT performance (Hambrick, 2007; Priem, Lyon, \& Dess, 1999). Since research on the effects on TMT composition and internal processes on TMT performance until now is inconclusive and sometimes inconsistent (Certo et al., 2006; see also chapter 2), an appropriate choice of TMT performance indicators might help to achieve more insight into the effects of TMT composition and processes and possibly explain previous inconsistent results.

Second, the study adds to the literature on performance evaluations and implicit leadership (Epitropaki \& Martin, 2005; Hooijberg \& Choi, 2000; Hooijberg et al., 1997), as the performance dimensions can be used to explore in more detail the expectations and evaluations that MMs have of their TMT. Since leadership effectiveness models and implicit leadership theories have been shown to be consequential for individual and organizational outcomes (Dirks \& Ferrin, 2002; Epitropaki \& 
Martin, 2005; Mayer \& Gavin, 2005), insight in the contents, determinants, and consequences of such models would be valuable. In this study, the establishment of the five performance dimensions provides insight in the contents of MMs' models of TMT performance. Future research could delve deeper into determinants and consequences of these models or could pay attention to the congruence between MMs' and TMT's expectations and evaluations of TMT performance.

Third, our results also provide a starting point for exploring the actual relationship between TMT and MMs in more detail. In line with previous research that has pointed at the importance of alignment and coordination between these two organizational echelons (Balogun \& Johnson, 2004; Floyd \& Wooldridge, 1997), our study gives insight in what one party in the relationship emphasizes when evaluating the performance of the other. It would be interesting to further assess the relationships between TMTs' actions and MMs' perceptions. For example, one could ask how the amount and type of communication from the TMT toward MMs are related to MMs' perceptions of TMT moral leadership, or if the degree to which the TMT is coordinating its actions toward MMs relates to company performance.

The dimension of 'TMT unity' might be particularly interesting in this respect, as almost no prior research has considered this aspect of TMT leadership. Since most of the studies on leadership expectations and evaluations have investigated individual-level leadership (Denison et al., 1995; Hooijberg \& Choi, 2000), a dimension of 'TMT unity', which only exists on the team level, was never an issue. Yet, our analyses showed that this factor is a separate dimension of TMT performance, which MMs in both countries found important. This supports recent qualitative findings on 'TMT unity in actions' as a process for ensuring TMT impact on lower echelons (Raes et al., 2007). Thus, in order to successfully perform its tasks, it is important that the TMT is acting as one unit that is consistent across time and situations in communicating its decisions and that MMs perceive the TMT to act as such. Future research could explore the role of TMT unity in more detail.

The results of this study also have some practical implications. First, our results provide TMTs with knowledge about MMs' expectations concerning top managerial performance. Researchers have argued before that leaders should enhance their knowledge about the performance expectations of their subordinates (Hooijberg \& Choi, 2000; Tsui et al., 1995). This is important for TMTs as well, as they face demands from different stakeholder groups, and these stakeholders make decisions to give or withhold resources that are required for organizational performance (Post, Preston, \& Sachs, 2002; Tsui et al., 1995). Yet, previous research has shown that many senior executives fail to recognize the importance of others' perceptions for their own reputation (Treviño, Hartman, \& Brown, 2000). Moreover, the outward appearance of TMTs and stakeholder uneasiness with TMT deterioration have been shown as part of the downward spiral of large corporate bankruptcies (Hambrick \& D'Aveni, 1992). MMs' emphasis on moral leadership might be particularly noteworthy in this respect, as previous research - albeit not on MMs specifically - has shown that organizations where employees see managers as practicing what they preach, experience higher organizational commitment, customer satisfaction, and financial performance (Mayer \& Gavin, 2005; Simons, 2002).

Furthermore, the identification and measurement of multiple dimensions of TMT performance could assist TMTs and supervisory boards in monitoring TMT impact more closely, and this study 
provides a first step into that direction. Since the outcomes of TMT work are more closely related to TMT than to organizational performance (Barrick et al., 2007) and a positive relationship between TMT and organizational performance exists (Elron, 1997), the timely monitoring of TMT performance could function as an early indicator for subsequent effects on the organizational level. Such outcome dimensions could also be of interest to trainers and coaches who work with TMTs to improve their work for both goal setting and for examining effects of their interventions (e.g., Kets de Vries, 2005).

\section{Limitations}

The results of this study should be seen in light of some limitations of the research. While we are confident to have identified important dimensions of TMT performance, future research should reassess their relevance for MMs and other stakeholder groups. Taking into account that this study was a first step in establishing a multi-dimensional model of TMT performance, we would welcome further developments in the definition and measurement of dimensions. This could also include studying the perspectives of other stakeholders of the TMT, by which it would then become possible to compare TMT performance expectations of different groups (see Hooijberg \& Choi, 2000, for comparisons of multi-source assessments of leadership effectiveness).

From a methodological perspective, we consider it an advantage to have had access to a relatively large pool of international respondents via the consultancy company. However, the inherent disadvantage was that we had relatively little control over the actual data collection process. In absence of that, we were limited in our possibilities to take actions to increase the response rate and get a multi-country sample. More in general, this research had an exploratory focus and although we drew on extensive research on MMs and the consequences of employees' cognitions about top leadership, we did not test such consequences in our research, nor did we relate MMs' perceptions to actual TMT performance. As such, this study should be considered as a first step in a process of understanding the dynamics between TMT actions and MMs' cognitions and the consequences of such dynamics.

\section{Conclusion}

Our research has provided insight in the dimensionality of TMT performance by exploring MMs' expectations and evaluations on the five performance dimensions company results, strategic leadership, connectedness, TMT unity, and moral leadership. Although a variety of indicators has been used for TMT performance, a comprehensive test of the dimensionality of this construct was lacking until now. The study illustrates the importance of MMs' expectations and evaluations as sources of insight in TMT performance. Obtaining the perceptions of important stakeholders as indicators for performance is already well-established for individual-level leadership (Denison et al., 1995; Hooijberg \& Choi, 2000), as well as in the psychology literature on nonmanagerial teams (Hackman, 1987, 2002). Yet, a comparable effort for TMTs was not undertaken until now. Since these expectations and evaluations were not significantly related to individual, organizational, and country differences, we propose that our five-dimensional model of TMT performance is relevant for MMs from different backgrounds, organizations, and countries. 


\title{
6
}

\section{The Interface of Top Management Team and Middle Managers: A Process Model}

\begin{abstract}
This chapter proposes a process model of the interface of top management team (TMT) and middle managers to address current inconsistent findings regarding TMT impact on organizational performance. Information exchange and mutual influencing are proposed as the key mechanisms of the interface. These affect strategic decision quality, top and middle managers' implementation commitment, and organizational performance. Building on role theory, the interface mechanisms are proposed to be influenced by TMT leadership style and middle managers' follower style and to shape TMT and middle managers' perceptions of each other. This chapter contributes to the literature on TMTs, middle managers, and TMT leadership.
\end{abstract}

This chapter is based on:

Raes, A. M. L., Heijltjes, M. G., Glunk, U., \& Roe, R. A. (2008) The interface of top management team and middle managers. Academy of Management Proceedings. 


\section{Introduction}

Both researchers and practitioners often assume that the performance of organizations is influenced by their top management team (TMT). According to the upper-echelons theory (Hambrick, 2007; Hambrick \& Mason, 1984), the composition of a TMT can influence strategic decision making and organizational performance (for reviews, see Carpenter, Geletkanycz, \& Sanders, 2004; Certo, Lester, Dalton, \& Dalton, 2006). This 'classical model' of TMT impact is schematically depicted in figure 6.1a. More recently, researchers have focused on TMT internal processes, such as conflict, communication, and behavioral integration as additional determinants of organizational performance and as mediators of the TMT composition - performance relationship (Amason, 1996; Carmeli \& Schaubroeck, 2006; Smith et al., 1994; see also chapter 2 of this dissertation). This 'intervening processes model' is depicted in figure $6.1 \mathrm{~b}$. Although TMT composition and internal processes have both been found to 'matter' for organizational performance, findings about their effects on outcomes are inconsistent (Barrick, Bradley, Kristof-Brown, \& Colbert, 2007; Certo et al., 2006). As a reaction to these inconsistent findings, researchers have suggested that there are other unexplored mechanisms that might more fully explain TMTs' impact on their organizations (Carpenter et al., 2004; Certo et al., 2006; Priem, Lyon, \& Dess, 1999).

The aim of this chapter is to explore one such mechanism: the way in which a TMT interacts with middle managers with regard to strategy making and implementation. Middle managers (MMs), the group of managers in the organizational layer between TMT and first-level supervisors (Dopson, Risk, \& Stewart, 1992) are 'linking pins' whose actions have both upward and downward influence in organizations (Floyd \& Wooldridge, 1992, 1997). MMs have the power to delay strategy implementation, reduce the quality of implementation, or even sabotage it completely (Floyd \& Wooldridge, 1997; Guth \& MacMillan, 1986; Pye, 2005). They can also influence how other people in the organization think about the TMT via their sensemaking function vis-à-vis subordinates (Gibson \& Schroeder, 2003; Sims, 2003) and influence the trust that their subordinates have in the TMT (Dirks \& Ferrin, 2002; Mayer \& Gavin, 2005; Simons, 2002). Thus, top managers depend on MMs for achieving organizational goals and have to find ways to gain MMs' commitment to their course of action. Despite the acknowledged importance of the alignment of TMT and MMs (Balogun \& Johnson, 2004; Currie \& Procter, 2005), research on these two echelons has largely evolved along separate lines. Hence, little is known about how the interaction between TMT and MMs can influence strategic decision quality and implementation, both precursors of organizational performance (Guth \& MacMillan, 1986; Srivastava, Bartol, \& Locke, 2006).

We define the interface of TMT and MMs as the verbal and nonverbal behaviors of these two echelons in relation to each other. In this chapter, we propose the 'interface model' as a process model of TMT impact on organizational performance through middle managers. To develop this model in detail, we build on theories related to TMT and MMs, as well as theories that shed light on the relationship between them. In particular, for understanding TMT functioning and organizational impact, we build on upper-echelons theory (Hambrick \& Mason, 1984) and research on teams' internal and external processes (Ancona \& Caldwell, 1992; Marks, Mathieu, \& Zaccaro, 2001). To understand the work of MMs, we build on theories regarding the function of MMs in organizations for 
strategy making and implementation (Currie \& Procter, 2005; Floyd \& Wooldridge, 1992, 1997; Wooldridge \& Floyd, 1990). And finally, to understand how these two echelons relate to each other, we build on role theory (Biddle, 1986; Katz \& Kahn, 1978), research on strategic leadership (Boal \& Hooijberg, 2000; Vera \& Crossan, 2004), and theories on the role of trust and control in organizations (Eisenhardt, 1989; Mayer, Davis, \& Schoorman, 1995).

Using these theories, we will first develop the theoretical background of the interface model and then present it in detail. The implications of the interface model are summarized in propositions throughout the chapter. We will end by addressing boundary conditions of the model and outlining implications for research on TMTs and MMs, as well as for practicing top and middle managers.

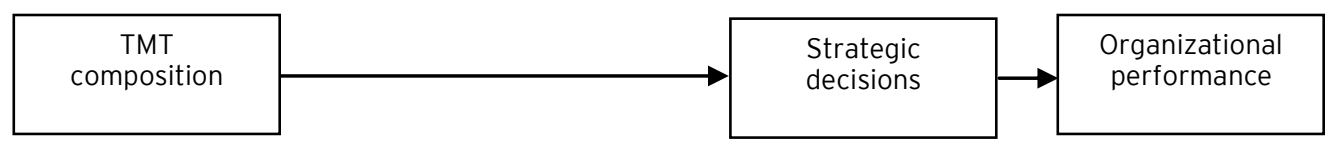

Figure 6.1a. The classical model of TMT impact on organizational performance (e.g., Hambrick \& Mason, 1984)

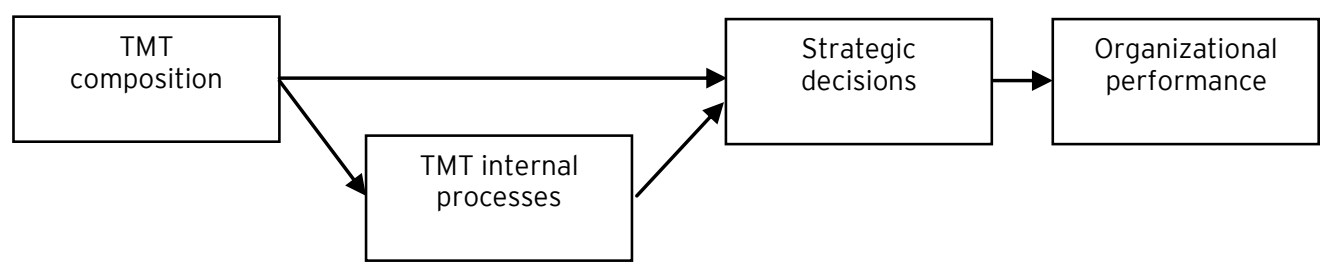

Figure 6.1b. The intervening processes model of TMT impact on organizational performance (e.g., Smith et al., 1994)

\section{Theoretical Background}

\section{Strategy Formulation and Implementation through TMT Leadership}

TMTs can influence their organizations' performance through their work of formulating and implementing strategy (Boal \& Hooijberg, 2000; Guth \& MacMillan, 1986; Hambrick \& Mason, 1984). While strategy making consists of the choice for a particular course of strategic action, strategy implementation comprises the subsequent actions to actually make that strategy happen (Mintzberg, 1983; Nutt, 1986). In the research on strategy making, the quality of strategic decisions has been a focal topic of interest. For example, Hambrick and Mason (1984), in presenting their upper-echelons 
theory, have reasoned that the strategic choices top managers make are a function of their values, cognitions, and personalities (Hambrick, 2007; Hambrick \& Mason, 1984). To optimize the quality of strategic decisions, researchers have pleaded for increasing the diversity in cognitive backgrounds of the managers involved in decision making and for having TMT interaction processes in which task related differences in information and opinions are discussed (Dooley \& Fryxell, 1999; Olson, Parayitam, \& Bao, 2007). Both TMT cognitive diversity and the open discussion of task-related disagreements have been found to positively relate to strategic decision quality (Amason, 1996; Dooley \& Fryxell, 1999; Olson et al., 2007).

Most TMT researchers have studied strategy making rather than implementation. Yet, decision implementation is key for a TMT to have an impact on its organization (Hickson, Miller, \& Wilson, 2003; Nutt, 1999). Even when a TMT internally achieves an optimal decision-making process and superior decision quality, the effects of its decisions ultimately depend upon the success with which their content materializes in the organization. Although decision-implementation success might be partly related to TMT internal processes (e.g., Amason, 1996; Dooley \& Fryxell, 1999), a successful decision-making process in itself does not guarantee success in implementation. On the contrary, about half of the decisions in organizations fail to achieve the intended effects and the main causes for these failures occur during decision implementation rather than decision making (Nutt, 1999). Furthermore, these causes are generally under management control instead of resulting from uncontrollable external factors (Hickson et al., 2003; Nutt, 1999).

For both strategy making and implementation, top managers rely on their relationships with others, who serve as channels of information and influence (Mintzberg, 1973; Tengblad, 2006; Weick, 1979). A detailed investigation of TMTs' activities showed that most time was spent on evaluating, monitoring, reviewing, and discussing current organizational affairs; activities that imply interaction with others (Roberto, 2003). In contrast, only $20 \%$ of TMT members' collective time was devoted to planning and formulating strategy (Roberto, 2003). Therefore, it is surprising that most of the research on TMT impact has focused on intra-team factors as determinants of organizational performance, while neglecting the fact that TMTs can only achieve their goals through their relationships with others.

As TMTs achieve strategy making and implementation through their relationships with followers, the task of a TMT implies strategic leadership (Cannella \& Monroe, 1997; Vera \& Crossan, 2004). Leadership, in general, can be described as "the process of influencing others to understand and agree about what needs to be done and how to do it, and the process of facilitating individual and collective efforts to accomplish shared objectives" (Yukl, 2006, p. 8). Strategic leadership in particular designates leadership by those managers at the top of organizations, and researchers have emphasized that this implies both strategic and relational aspects (Cannella \& Monroe, 1997).

Some evidence exists that studying TMT leadership generates explanatory power when predicting organizational performance. For example, previous research has shown that TMTs in which team members possess superior skills for managing people have a higher positive impact on organizational performance than TMTs with superior intellectual abilities (Carmeli \& Tishler, 2006). The amount and quality of TMT members' intra- and extra-organizational relationships, in terms of network-size, network-range, and the strength of ties, are also positively related to organizational 
performance (Collins \& Clark, 2003). Thus, maintaining relationships to intra-organizational actors is an inherent aspect of TMT members' work and doing so successfully is beneficial for organizational performance.

\section{The Importance of Middle Managers for Strategy Making and Implementation}

A critical intra-organizational group of stakeholders for a TMT is the echelon of middle managers - those managers who mediate between top and operating management (Currie \& Procter, 2005; Floyd \& Lane, 2000; Floyd \& Wooldridge, 1997). Scholars studying MMs have emphasized their roles in both strategy making and implementation (Currie \& Procter, 2005; Floyd \& Wooldridge, $1992,1997)$. MMs influence strategy making by, for example, synthesizing information, championing

alternatives (Currie \& Procter, 2005; Floyd \& Wooldridge, 1992), and selling issues to top management (Dutton \& Ashford, 1993; Dutton, Ashford, O'Neill, Hayes, \& Wierba, 1997). MMs can also influence strategy implementation by facilitating necessary adaptation of the strategy and by putting into practice the selected strategy (Currie \& Procter, 2005). The involvement of MMs in strategy has been associated with increased organizational performance (Wooldridge \& Floyd, 1990). On the negative side, when MMs are not committed to implementation, they may create obstacles or sabotage it (Guth \& MacMillan, 1986). Thus, although strategy making and implementation are traditionally seen as the exclusive domain of top management, a TMT depends on MMs for the successful execution of both of them.

As indicators for the success of strategy making, TMT researchers have focused on the quality of strategic decisions (Amason, 1996; Dooley \& Fryxell, 1999; Hambrick \& Mason, 1984). Decision quality can be described as the normative evaluation of the decisions that are taken, to be reviewed in light of the degree to which they contribute to organizational performance in the short and longer term (Amason, 1996; Edmondson, Roberto, \& Watkins, 2003). As indicator for the success of strategy implementation, the commitment from both top and middle managers to implementing strategic decisions has been emphasized (Amason, 1996; Dooley \& Fryxell, 1999; Nutt, 1986). Decision commitment is managers' cognitive and affective attachment toward implementing strategic decisions and their willingness to exert high levels of effort to achieve this. TMT commitment has been found to positively relate to implementation success (Dooley, Fryxell, \& Judge, 2000). When using the term 'decision commitment' in this chapter, we mean the commitment of both top and middle managers.

In summary, the TMT literature has traditionally focused on how TMT composition and internal processes influence decision quality (Carpenter et al., 2004; Hambrick \& Mason, 1984) and, to a lesser extent, TMT decision commitment (Dooley \& Fryxell, 1999; Dooley et al., 2000). However, the previous discussion suggests that decision quality and decision commitment are actually achieved through the TMT's interaction with MMs. In studies that aim to explain TMT impact on organizations, a failure to incorporate the interaction between TMT and MMs in explanations of organizational performance is thus likely to result in underspecified models. The current inconsistent findings regarding how TMT composition and internal processes relate to decisional, TMT, and organizational outcomes support this conclusion (Carpenter et al., 2004; Certo et al., 2006; Hambrick, 2007; see also chapter 2). The literature on MMs has focused on MMs' contribution to strategy making and 
implementation, but has not addressed the actual interactions of TMT and MMs. Hence, little is known about what TMTs do to manage the interface with MMs and vice versa. Furthermore, the issue of how TMT composition and internal processes influence the interactions between TMT and MMs has never been addressed.

In the following, we will introduce the interface model and outline key mechanisms that describe the interaction of TMT and MMs in terms of information and influence. Then, we continue with elaborating on how TMT and MM related factors influence these interface mechanisms.

\section{The Interface Model}

According to the Oxford English dictionary, an interface is "A means or place of interaction between two systems." In our model, the interface concerns two organizational echelons: top management team and middle managers. They interact through their observable, verbal and non-verbal, behavior to each other. Both parties have an expertise, power, and interest base and they are interdependent in their aim of achieving optimal organizational performance through strategy making and implementation.

The relationship of TMT and MMs can be characterized as one of a leader - the TMT, and followers - the MMs. However, it is different from regular leadership relationships in that the leader function is occupied by a team of top managers instead of a single individual. Although the 'teamness' of TMTs is a topic of debate among scholars (Barrick et al., 2007; Hambrick, 1994), it seems that many organizations nowadays do have teams at the top in which its members function on the base of shared goals and responsibilities (Edmondson \& Smith, 2006; O'Toole, Galbraith, \& Lawler, 2002; Wageman, Nunes, Burruss, \& Hackman, 2008). The interface model applies to organizations in which the TMT exists as a distinct organizational entity (e.g., Cohen \& Bailey, 1997), which is perceived as such by MMs. The implications of what it means for a TMT to lead 'as a team' will be outlined in more detail later in the chapter.

Role theory (Biddle, 1986; Katz \& Kahn, 1978) posits that organizational actors hold social positions in their organization and that their behavior is influenced by their perceptions of and expectations about themselves and each other in their positions. For the interface model, this implies that TMT and MMs understand the TMT to have a leadership role and MMs to have a follower role. The interactions between TMT and MMs are thus influenced by their expectations of each other in their respective roles and will be evaluated against those role expectations (see chapter 5 for an assessment of MMs' expectations and evaluations of their TMTs). TMT and MMs might also have other roles - according to themselves and/or others - and associated behavioral patterns. Yet, we expect that the roles of leader and follower are salient and influential for TMT and MMs and influence their interaction in the interface.

Figure 6.2 presents the interface model of TMT impact on organizational performance. We posit that the key mechanisms in the interface are the exchange of information and the management of mutual influence. In line with role theory and the description of a 'role episode' (Katz \& Kahn, 1978), we propose that TMT leadership style and MM follower style influence these interface mechanisms and that TMT perceptions of MMs and MMs' perceptions of the TMT are outcomes of the 
interface mechanisms. Subsequently, TMT perceptions influence TMT leadership style and MMs' perceptions influence MM follower style via a mechanism of trust. To embed the interface model in the current TMT paradigm, we also include TMT composition and internal processes, which are proposed to influence both TMT leadership style and TMT perceptions about MMs.

In the following, we will address the elements and relationships of the interface model. First, we describe the interface mechanisms information exchange and mutual influencing and outline how they can be expected to influence strategic decision quality and implementation. Then, we address the primary determinants of the interface mechanisms - TMT leadership style and MM follower style and continue with outcomes of the interface mechanisms: TMT and MMs' perceptions of each other's integrity. Finally, we complete the episode by outlining how TMT and MMs' perceptions influence their leadership and follower styles, respectively.

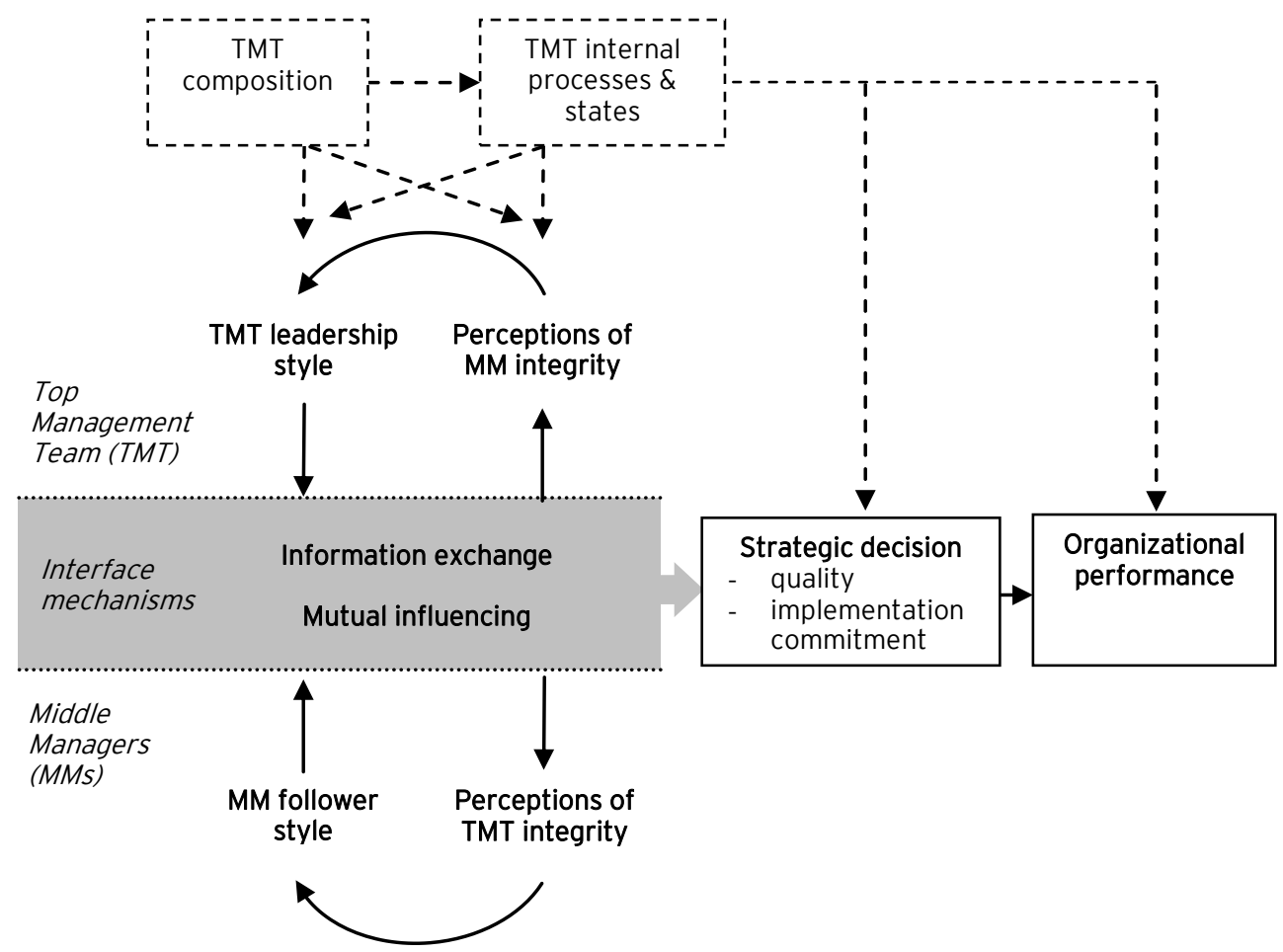

Figure 6.2. The interface model of TMT impact on organizational performance and, indicated with dashed lines, the relationships of the model to previous research on TMT impact 


\section{Interface Mechanisms: Information Exchange and Mutual Influencing}

A recent replication and update of Mintzberg's (1973) 'The nature of managerial work' showed that top managers spend on average $69 \%$ of their time on interacting with subordinates (Tengblad, 2006). Furthermore, about $60 \%$ of the verbal contacts of the CEOs' under study were classified as 'informational', consisting of the giving, receiving, and reviewing of information (Tengblad, 2006). Although this study did not further classify subordinates as being MMs or not, we may assume that managers in this adjacent layer of the organization are heavily involved in these informational processes. Other research has indeed shown that MMs are important sources of information for top management (Currie \& Procter, 2005; Dutton \& Ashford, 1993). Researchers of upper-echelons theory, using an information-processing argument, have emphasized that the incorporation of more and more diverse information in decision making will yield a higher decision quality (Hambrick \& Mason, 1984; Leifer \& Mills, 1996). Consistent with this theoretical rationale, within-TMT cognitive diversity and TMT internal processes in which task-related differences in information and opinions are discussed, have been found to positively relate to decision quality and organizational performance (Dooley \& Fryxell, 1999; Olson et al., 2007).

We propose that the information-processing argument can be extended to the interaction between TMT and MMs. Thus, when the interaction between TMT and MMs is characterized by taskrelated differences and the open discussion of disagreements, decision quality will benefit. MMs, because of their organizational position, have better access to information from operational levels of the organization than the TMT has (Dutton \& Ashford, 1993; Floyd \& Wooldridge, 1992). Therefore, MMs' information is likely to be more discrepant from the information generated by the TMT itself and its inclusion can lead to more comprehensive and context sensitive strategies that have a greater likelihood of successful implementation (e.g., Currie \& Procter, 2005). Thus, an important mechanism of the interface of TMT and MMs is the exchange of information between TMT and MMs.

The task of the TMT also implies ensuring MMs' commitment to strategy implementation, which researchers have previously emphasized as a key aspect of strategic leadership (Boal \& Hooijberg, 2000). There are multiple ways by which a TMT could achieve such commitment. A first approach is to give MMs the opportunity of 'voice' during the decision-making process. When people involved in a decision have the opportunity to express their ideas and concerns, their understanding, acceptance, and commitment to the decision are likely to increase (Amason, 1996; Dooley \& Fryxell, 1999; Peterson, 1997). Second, expectancy-value theory proposes that MMs' commitment is based on their expectancies of the results of strategic decisions in combination with the extent to which these results are desirable for them (Guth \& MacMillan, 1986; Lawler, 1994). MMs' commitment to a decision and course of action can be increased when they expect that the proposed strategy will work and when they perceive an alignment in the strategy's results and their own desired results (Guth \& MacMillan, 1986). Concretely, a TMT could influence MMs' perceptions by listening to and understanding MMs' positions and by exercising influence mechanisms such as persuasion, coercion and obligation to align MMs' goals with the TMT's goals (Guth \& MacMillan, 1986). Third, there is the theory of perceived procedural justice, in which MMs' perceptions of the fairness of the TMT's decision-making processes are a major determinant of their reactions to these decisions (Kim \& Mauborgne, 1993; Korsgaard, Schweiger, \& Sapienza, 1995). Perceptions of procedural justice are of 
general importance for organizational employees and can increase decision commitment and trust in leaders (Korsgaard et al., 1995). Thus, if the TMT can convince MMs of the procedural fairness of the decision process, MMs' commitment is likely to increase.

Conversely, MMs influence the TMT in order to shape strategy making and implementation (Currie \& Procter, 2005; Floyd \& Wooldridge, 1992, 1997). The extent to which MMs engage in such influencing behavior might depend on MMs' structural position in the organization (Currie \& Procter, 2005; Dutton \& Ashford, 1993), their perceptions of openness and support of top management (Dutton \& Ashford, 1993), their perceptions of favorability of the context (Dutton et al., 1997), and their perceptions of top management's image of themselves (Dutton \& Ashford, 1993; Dutton et al., 1997). When MMs do exert influence, decision quality may increase through the availability of more comprehensive information for the TMT; MM decision commitment may increase through the positive experiences associated with voice (e.g., Amason, 1996; Dooley \& Fryxell, 1999; Peterson, 1997), increased expectancies that valued outcomes will be achieved (e.g., Guth \& MacMillan, 1986; Lawler, 1994), and perceptions of greater procedural justice in the decision-making process (e.g., Kim \& Mauborgne, 1993; Korsgaard et al., 1995).

In conclusion, two key mechanisms can be derived that shape the interaction of TMT and MMs: information exchange and mutual influencing. First, in order to achieve high quality decisions, the TMT needs information from MMs, as this is likely to be of incremental value beyond information from the TMT members themselves. MMs receive information and feedback from the TMT regarding the intended strategy and about the results of their efforts. Therefore, a key aspect of the interface of TMT and MMs is the two-way process of information exchange between TMT and MMs. The quality of information exchange is higher when it is characterized by timely, accurate, and sufficient information exchange between TMT to MMs.

Second, in order to receive the necessary information and enhance MMs' decision commitment, the TMT will exert influence on them. MMs also influence the TMT to have an impact on the content of strategy by championing alternatives, synthesizing information, or issue selling (Dutton \& Ashford, 1993; Dutton et al., 1997; Floyd \& Wooldridge, 1992). Therefore, a second twoway process in the interface of TMT and MMs is mutual influencing. When the exercise of influence is mutually balanced within the realm of both parties' responsibilities and power bases, TMT and MMs will effectively influence each others' behavior. This implies that the TMT exercises influence over the expectancies and perceived procedural justice of MMs and MMs' exercise influence over the content and implementation of strategic decisions. If one of these two conditions is not satisfied, mutual influencing can be seen as unbalanced and decision quality and commitment will suffer. The following two propositions summarize the implications of this reasoning:

Proposition 1. When information exchange between TMT and MMs is of high quality, strategic decision quality and implementation commitment will be higher.

Proposition 2. When mutual influencing between TMT and MMs is balanced rather than unbalanced, strategic decision quality and implementation commitment will be higher. 


\section{The Role of Trust for the Interface Model}

TMT and MMs depend on each other for the attainment of information and both have their own bases from which to exercise influence. However, the parties are not equally powerful and asymmetries of information and influence exist. Such asymmetries are described as the degrees to which TMT and MMs hold divergent information and influence with regard to a particular strategic decision (e.g., Edmondson et al., 2003). The TMT has the formal power base of its organizational function and has an overview of a wide array of information from many intra- and extraorganizational sources (Collins \& Clark, 2003). Thus, the TMT derives its information and influence from its formal position at the top of the organization. MMs have good access to intra-organizational information from lower echelons and they have the power to delay strategy implementation and create obstacles (Balogun \& Johnson, 2004; Guth \& MacMillan, 1986). Thus, MMs derive their information and influence from their organizational role as linking pins. Given the different organizational roles of TMT and MMs, there might also be an asymmetry of interests between both parties, as MMs might pursue goals in the primary interest of their business units that shape their choices and behavior, which are not necessarily fully in line with the goals of top management (Balogun \& Johnson, 2004; Guth \& MacMillan, 1986).

The asymmetry of information, influence, and interests in a relationship between two parties is a primary assumption of agency theory (Eisenhardt, 1989). This theory predicts that in absence of complete information and with possibly diverging interest of TMT and MMs, the TMT will experience a risk in relying on the information from MMs. To reduce this risk, the TMT will be inclined to install monitoring mechanisms in their interactions with MMs, the amount of which will vary with the TMT's trust in MMs and the team's perception of information and interest alignment (e.g., Eisenhardt, 1989). Trust can be defined as a "psychological state comprising the intention to accept vulnerability based upon positive expectations of the intention of the behavior of another" (Rousseau, Sitkin, Burt, \& Camerer, 1998, p. 395). In general, the more trustworthy employees are perceived to be, the less top management will monitor them (Langfred, 2004).

MMs, as followers and 'agents' in the interface, also experience the asymmetry of information, influence, and interests. Although the TMT has formal and informal control mechanisms to obtain MMs' information and compliance, we propose that MMs have a considerable degree of control over the extent to which they allow top management's influence. Therefore, MMs' trust in the TMT is likely to play an important role in their behavior toward the TMT. Trust in leadership has been proposed to affect individual behavior in two different ways: by reciprocating an experienced positive relationship with the leader with positive behavior, and/or by refraining from non-productive controlling mechanism due to confidence in the character of the leader (Dirks \& Ferrin, 2002; Mayer \& Gavin, 2005). Thus, when MMs' trust in the TMT is high, they will accept the vulnerability that comes with the power difference between them, and they can be expected to spend more time on productive organizational efforts and less on self-protective and defensive behaviors (Mayer \& Gavin, 2005).

In summary, the TMT's trust in MMs will determine how much influence they allow from MMs in decision making and the extent to which they rely on formal monitoring mechanisms (e.g., Smith et al., 1994). MMs' trust in the TMT drives the extent to which MMs are open to accept TMT influence and their willingness to provide accurate information to the TMT. MMs' trust will influence and be 
influenced by MMs' perceptions of the TMT, its functioning, and its performance. In the following paragraphs, we will introduce and elaborate on 'TMT leadership style' and 'MM follower style', which are hypothesized to be influenced by TMTs' and MMs' trust in each other and are proposed as the key determinants of the interface mechanisms of information exchange and mutual influencing.

\section{Determinants of Interface Mechanisms: TMT Leadership Style and MM Follower Style}

We have pointed out that a TMT's main interest in the interface with MMs is to ensure that information and feedback come through, to make high quality strategic decisions, and to generate MMs' commitment to the implementation of these decisions. Leadership style is the specific manner and approach of influencing others and consists of a series of actions from leaders toward their followers (Yukl, 2006). For understanding TMT leadership style, it has to be acknowledged that having a team as the origin of leadership actions is different from having an individual performing those actions. Previous literature has started investigating the issue of shared leadership (Ensley, Hmieleski, \& Pearce, 2006; Ensley, Pearson, \& Pearce, 2003), but the 'sharedness' of this concept applies to the alternating leadership roles among TMT members. These studies do not address the issue of how a TMT coordinates and executes its collective leadership actions toward MMs or others. A recent case study of TMT sensemaking pointed out that TMT members collectively make sense of their leadership role toward MMs and analyzed the contents of such sensemaking (Raes, Glunk, Heijltjes, \& Roe, 2007; see also chapter 4). We propose here that collective sensemaking about TMT leadership will translate into the actual leadership style that a TMT as a team exhibits towards MMs.

Based on the work of Raes and colleagues (2007) and in absence of further conceptual or theoretical work on what TMT collective leadership toward MMs implies, we propose - as a first step in developing this construct - that TMT leadership style might vary in content and in betweenmember consistency. These dimensions will be addressed in more detail below. As we proposed trust theory to understand how TMT leadership style influences the interface mechanisms of information exchange and mutual influencing, we focus on two key factors related to trust in which TMTs might vary with regard to the content of leadership: TMT monitoring and TMT openness to information.

TMT monitoring. TMT monitoring is the extent to which the TMT relies on formal control mechanisms, such as rules and procedures, for the surveillance and awareness of MMs' activities and outputs (Langfred, 2004; Smith et al., 1994). Monitoring organizational systems is a frequent activity of TMTs (Roberto, 2003) and has been identified as a key behavior that routinizes contact between people in organizations (Eisenhardt, 1989; Langfred, 2004). In line with agency theory and recent findings on the role of trust and monitoring in teams (Eisenhardt, 1989; Langfred, 2004), we expect that a moderate amount of TMT monitoring of MMs is optimal for achieving high-quality information exchange and mutual influencing. Too much monitoring from the TMT is likely to result in a negative cycle in which MMs' perceptions of not being trusted by their TMT leads MMs to act in accordance with these perceptions (Brower, Lester, Korsgaard, \& Dineen, 2008). This will decrease MMs' willingness to provide information to the TMT, as they rather keep that information for themselves to protect their own position (e.g., Mayer \& Gavin, 2005). On the other hand, too little monitoring, in combination with an asymmetry of interests between TMT and MMs, can be expected to lead to MMs acting opportunistic and mainly in their self-interests (Eisenhardt, 1989; Langfred, 2004). 
TMT openness to information. TMT openness to information is the degree to which the TMT actively seeks information from MMs that is relevant for strategy making and implementation. This might also include seeking feedback about TMT functioning and strategic or operational matters and can be more or less formalized. Much information comes to TMTs via formalized organizational systems (Roberto, 2003). However, MMs can provide additional information that is more fluid and less easily obtainable for a TMT and we expect that TMTs' efforts to obtain this information are beneficial for information exchange in the interface. Since an often mentioned risk for a TMT is to fall victim to closed-mindedness and to become detached from reality (Janis, 1982; Peterson, Owens, Tetlock, Fan, \& Martorana, 1998), we expect that explicitly seeking information and feedback from MMs is essential for fulfilling the interface mechanisms of information exchange and mutual influencing.

When MMs perceive the TMT to be open to information and feedback from their side, MMs will have more trust in the TMT and will be more likely to engage in high-quality information exchange. Along the same line, when the TMT is open to information and MMs perceive the TMT to act as such, mutual influencing is likely to be balanced, so that the TMT can influence MMs' expectancies and perceptions of procedural justice and MMs can influence the TMT in strategy making and implementation.

Between-member consistency. Consistency in leadership actions is the extent to which the behavior of the TMT toward MMs is similar across TMT members, time and situations (e.g., Kelley, 1973). This also implies consistency in the underlying values, goals, and intentions, which is implicitly communicated with TMT behavior. The concept is comparable to what has been previously designated as 'TMT unity in actions' (Raes et al., 2007). We propose that between-TMT-member consistency in actions is beneficial for information exchange and mutual influencing for two reasons. First, when TMT members' behavior with regard to obtaining information or achieving decision commitment from MMs is more consistent between TMT members and across time, the cumulative effect of these efforts is higher and TMT members will be more efficient in sending and receiving information respectively to and from MMs. Second, when TMT members are more consistent in their behavior, MMs attribute the observed TMT behavior more to the capabilities of the TMT as a whole than to external circumstances or single individuals (e.g., Malle \& Knobe, 1997; Martinko, Harvey, \& Douglas, 2007; Raelin, 1993). When these attributions are positive, MMs will see the TMT as more capable and credible, thereby enhancing their trust in the TMT (Mayer et al., 1995; Mayer \& Gavin, 2005) and, hence, the quality of information exchange and balance of mutual influence.

Proposition 3. A moderate level of TMT monitoring will be positively related to the quality of information exchange and the balancing of mutual influence between TMT and MMs, whereas both high and low levels of monitoring will be negatively related to the quality of information exchange and the balancing of mutual influence between TMT and MMs.

Proposition 4. TMT openness to information will be positively related to the quality of information exchange and the balancing of mutual influence between TMT and MMs. 
Proposition 5. Consistency between TMT members across time and situations in leadership behavior toward MMs will be positively related to the quality of information exchange and the balancing of mutual influence between TMT and MMs.

In the previous sections, we have outlined how aspects of TMT leadership style - the specific manner and approach a TMT deploys to influence MMs - are likely to influence the interface mechanisms of information exchange and mutual influencing through the trust that TMT and MMs have in each other. In the following, we will address how MM follower style can be expected to influence the interface mechanisms. Although the concept of 'follower style' has not been extensively investigated in current literature, there is some research that addresses this 'specific manner and approach MMs deploy to influence and be influenced by the TMT consisting of a series of actions of MMs to their TMT' (e.g., Kelley, 1992; Yukl, 2006). To outline aspects of MM followership, we have drawn on existing research on this construct and adapted it to the setting of MMs being followers of a TMT. Hence, we propose two factors of MM follower style: active engagement and political behavior. Both factors are expected to influence the interface mechanisms through the trust that MMs have in their TMT.

MM active engagement. MM active engagement is the extent to which MMs are interested and actively involved in thinking about strategy making and implementation and refrain from extensive self-protective behavior. In the research in which follower style is described with regard to individual leaders, a distinction is made between 'active' versus 'passive' followers and between 'critical independent' versus 'non-critical dependent' followers (Kelley, 1992). In addition, research on employees' trust in leadership has focused on the extent to which employees focus on their work versus spend time on self-protective behavior (Mayer \& Gavin, 2005). Self-protective behavior comes from employees' unwillingness to be vulnerable to management, and consists of actions that aim to decrease the risk that management will do harm to them. For example, employees may extensively document their performance achievements to prevent management from firing them (Mayer \& Gavin, 2005). Based on this previous research, we expect that MMs' active engagement will positively relate to the quality of information exchange and the balance of mutual influence. When MMs are interested in strategy making and implementation, they are likely to contribute with more and better resources to the information exchange with the TMT. When MMs' behavior is focused upon making productive contributions instead of extensive self-protection and when they have more trust in the TMT, we expect that they will be more inclined to allow top management's influence and exert influence themselves.

MM political behavior. An additional dimension of followership that comes into play when there is a team instead of a single individual in a leadership position is MMs' political behavior. Political behaviors are "the observable, but often covert actions, by which executives enhance their power to influence decisions" (Eisenhardt \& Bourgeois, 1988, p. 738). They are detrimental for organizational performance, because they are time-consuming and restrict an open information-flow (Eisenhardt \& Bourgeois, 1988). In the case of MMs, political behavior toward the TMT would imply that they seek coalitions with individual TMT members and try to play TMT members off against each other to achieve their goals. We expect that MMs will engage in more political behavior when they have less 
trust in the TMT than when they have more trust, because they are less confident that they will be able to exert influence through open communication. Political behavior in turn is expected to decrease the quality of information exchange and the balancing of mutual influence, because it focuses MMs' motivation and energy on the process of politics instead of organizational goals. In summary, we propose that:

Proposition 6. MM active engagement will be positively related to the quality of information exchange and the balancing of mutual influence between TMT and MMs.

Proposition 7. MM political behavior will be negatively related to the quality of information exchange and the balancing of mutual influence between TMT and MMs.

\section{TMT and MMs' Perceptions of Integrity}

In line with role theory (Biddle, 1986; Katz \& Kahn, 1978), we propose that MMs' trust in the TMT and the TMT's trust in MMs are shaped by their perceptions of each other during their interaction in the interface. MMs have many opportunities to observe the TMT's behavior at formal and informal occasions. In addition, MMs are salient and important organizational actors through which TMTs implement strategy (Balogun \& Johnson, 2004; Raes et al., 2007). Social psychological research on attribution processes has shown that individuals are generally motivated to search for causes of events and assign responsibility for the outcomes of events (Brehm, Kassin, \& Fein, 1999; Malle \& Knobe, 1997) and that such attributions are consequential for subsequent attitudes and behavior (Gibson \& Schroeder, 2003; Mayer \& Gavin, 2005). Therefore, we expect that TMT and MMs' perceptions are shaped by the interface mechanisms and are consequential for their trust in each other. TMT and MMs may have many different perceptions of each other that might be consequential for their trust and subsequent behavior (e.g., Dirks \& Ferrin, 2002; Mayer \& Gavin, 2005; Simons, 2002), but here we focus on perceptions of integrity, which can be expected to be particularly central in this context (see also chapter 5).

The concept of integrity is commonly used in both the scientific community and popular press and is typically associated with honesty, consistency, and the adherence to moral principles (Parry \& Proctor-Thomson, 2002; Simons, 2002; Worden, 2003). Current debates evolve along the question if integrity includes the morality of principles or only the adherence to principles (Simons, 2002; Worden, 2003). We follow the general conception of integrity as the perceived pattern of word-deed alignment or misalignment from an individual or team with regard to a variety of issues (Simons, 2002). Perceived integrity of an entity is subjective in nature and is likely to be influenced by the actor (here, the TMT), the perceiver (here, an individual MM), the relationship between actor and observer, and the history and state of mind of the perceiver (Mayer \& Gavin, 2005; Simons, 2002). Perceptions of integrity have mostly been studied from the perspective of followers about their leaders and are a key determinant of employees' trust in leadership (Mayer et al., 1995; Mayer \& Gavin, 2005). We propose that the effects of perceptions of integrity will be similar with respect to leaders' perceptions of their followers. Thus, we assume that MMs generate perceptions of their TMT and that the TMT generates perceptions of MMs. 
While exchanging information and balancing mutual influence in the interface, TMT and MMS generate perceptions of integrity of each other. Since these perceptions apply to the alignment of words and deeds of the other party, the main determinant is the actual pattern of word-deed alignment (Simons, 2002). However, perceptual filters may be at place that shape the field of vision and the interpretations of the observers, such as the dependence on the other party or the focal person's caring about a certain issue (Simons, 2002). We expect that a high quality information exchange and balance of mutual interest are beneficial for integrity perceptions. Because a high quality information exchange also implies feedback loops about issues discussed before, this should increase the number of positive perceptions of word-deed alignment. Although such feedback loops might also emphasize the absence of deeds following the words, it is likely that the absence of such feedback loops would be even more detrimental. Likewise, when mutual influencing is balanced and both parties are satisfied with the balance and amount of influence, this could make it more likely that filters are coloured favourably for the other party and they are sometimes given the 'benefit of the doubts' in cases where the actual word-deed alignment is unclear.

TMT and MMs' perceptions of integrity also feed back in their leadership and follower styles respectively via their influence on trust. Therefore, MMs' perceptions of high TMT integrity can be expected to positively influence $\mathrm{MMs}^{\prime}$ active engagement and negatively influence MMs' political behavior, because such perceptions increase MMs' trust in the TMT. Along the same line, we expect that a TMT's perceptions of high MM integrity will increase their trust in MMs, and, hence, decrease monitoring behavior and increase openness to information.

\section{Proposition 8. High-quality information exchange and the balancing of mutual interests between TMT and MMs will result in perceptions of greater integrity among TMT and MMs of the other party.}

Proposition 9. TMT perceptions of MM integrity will decrease TMT monitoring behavior and increase TMT openness to information.

Proposition 10. MM perceptions of TMT integrity will increase MM active engagement and decrease MM political behavior.

\section{Discussion and Implications}

In the previous sections of this chapter, we have described the interface model of TMT and MMs. We have outlined how the interface mechanisms of information exchange and mutual influencing relate to strategic decision quality and implementation commitment, which are both precursors of organizational performance. We have introduced the concepts of TMT leadership style, MM follower style, and have argued that these concepts are influenced by TMT and MMs' perceptions of each other. In the final parts of this paper, we will outline how the interface model can be related to previous research on TMT impact on organizational performance. We will also highlight important 
boundary conditions of the applicability of the interface model, and describe implications of our model for research and practice.

\section{Existing TMT Research and the Interface Model}

The current TMT literature seeks to understand TMT impact on organizational performance. In doing so, researchers have focused, amongst others, on TMT composition and internal processes as performance determinants of interest (Carpenter et al., 2004; Hambrick, 2007). However the effects of these factors on organizational performance are sometimes inconsistent and inconclusive (Barrick et al., 2007; Certo et al., 2006; Elron, 1997). Therefore, researchers have suggested exploring additional mechanisms of interests and we have proposed that the interface of TMT and MMs may entail such mechanisms. In this section, we will discuss how the interface model can be integrated with existing research. That is, we will describe how TMT composition and internal processes relate to TMT leadership style and TMT perceptions of MM integrity.

We have reasoned that TMT leadership style can vary in content and consistency. As far as we are aware, no research until now has addressed how a TMT as a team coordinates leadership actions toward MMs or others. However, there is some research on nonmanagerial project teams, which suggests that the way in which teams act towards others in their environment is influenced by what happens inside the team (Ancona \& Bresman, 2007; Ancona \& Caldwell, 1992). Although project teams' activities toward others are different from a TMT leading MMs, especially in terms of the hierarchical power difference between TMT and MMs, the theoretical implications of this work are informative and may help understanding TMT leadership at the interface with MMs. From this research, it becomes clear that teams' 'external processes' can be influenced by both the composition and the internal dynamics of a team (Ancona \& Caldwell, 1992). Therefore, we will examine how TMT leadership style can be influenced by both the characteristics of individual TMT members and TMT internal processes.

TMT composition. The composition of the TMT can influence the content of TMT leadership in terms of monitoring and openness to information as well as TMT perceptions of MMs' integrity. Building on Hambrick and Mason's upper-echelons theory (Hambrick, 2007; Hambrick \& Mason, 1984), we propose that TMT members' values, cognitions, and personalities shape their leadership behavior and perceptions of integrity. For example, when TMT members value close control and directive leadership, they can be expected to engage in more monitoring and to be less open to information and feedback from MMs. This reasoning is also consistent with other research on individual level leadership, in which leaders' values and motivations have been shown to be related to their leadership style (Hooijberg \& Choi, 2000; Hooijberg, Hunt, \& Dodge, 1997)

In addition to the effects of the 'mean levels' of TMT members' characteristics, researchers studying TMT composition have also focused on the effects of homogeneity and heterogeneity of managers' characteristics (Cannella \& Holcomb, 2005; Hambrick \& Mason, 1984). In this respect, diversity - the term often used to designate the extent to which a TMT is heterogeneous with regard to its members' characteristics - has been referred to as a 'double-edged sword' (Milliken $\&$ Martins, 1996). Although diversity is often theorized to be beneficial for teams with high informationprocessing demands, it has also been shown to lead to increased conflict and decreased social 
cohesion, hampering team performance (Harrison, Price, \& Bell, 1998). This would suggest that diversity in TMT members' values and cognitions with regard to their leadership style can negatively relate to the consistency of TMT leadership behavior.

TMT structure and internal processes. In order to effectively perform their leadership task, a TMT needs to achieve, at least in a minimal matter, some shared understanding about the collective leadership actions of the team, which has previously been analyzed as TMT sensemaking about leadership (Raes et al., 2007). One aspect of TMT structure - interdependence - and one internal process - relationship conflict - can be expected to be particularly influential for the content and consistency of TMT leadership. Previous research on TMT interdependence has shown that the extent to which a TMT engages in information-exchange, collaborative behavior, and joint decision making is positively related to organizational performance (Barrick et al., 2007; Carmeli \& Schaubroeck, 2006; Lubatkin, Simsek, Yan, \& Veiga, 2006). Other research has pointed at TMT collective action-defined as the TMT's ability to work together while retaining the capacity for ongoing questioning and debate throughout the strategy process-as crucial for TMT impact on organizations (Jarzabkowski \& Searle, 2004 , p. 405). This would suggest that high TMT interdependence will positively influence the consistency of TMT leadership behavior toward MMs.

TMT relationship conflict can be described as the interpersonal incompatibilities among TMT members, which typically include tension, animosity, and annoyance (Jehn, 1995) and has been found to be negatively related to decisional and organizational performance (Amason, 1996; Rau, 2005). Since relationship conflict decreases the quality of interpersonal relationships, we expect that it will result in less willingness among TMT members to coordinate their actions toward middle managers so that less consistency in leadership behavior is achieved.

\section{Boundary Conditions of the Interface Model}

Although the applicability of the interface model in different organizations remains to be tested empirically, there are a few a-priori boundary conditions that we will address now. The first is that the model applies only to organizations with a relatively large size. An important reason for the importance of the interface is $\mathrm{MMs}^{\prime}$ influence in strategy making and implementation (Currie \& Procter, 2005; Floyd \& Wooldridge, 1992; Wooldridge \& Floyd, 1990). Such a role of MMs is most likely in organizations with a considerable number of employees - from several hundred onwards - as the TMT depends more on information access from MMs when they have less opportunities themselves to interact with their employees. Along the same line, the interface would be particularly important for complex organizations with a multi-divisional structure or operating in multiple countries.

Another boundary condition of our model is that it assumes that MMs have some expectations regarding the 'teamness' of their TMT (e.g., Hambrick, 1994). Although the actual unity and TMT members' consistency in leadership might vary, thus producing differences in leadership style and MMs' perceptions, this reasoning does not apply if MMs do not in itself expect some degree of consistency or unity in actions from their TMT. This also implies that we assume that MMs in dealing with TMT members, perceive TMT members primarily as representatives of the TMT as a whole, rather than as single top-level managers. People have a tendency to see members that belong to a 
different group than their own ('the outgroup') as more homogeneous in terms of personal characteristics and behaviors (Tajfel \& Turner, 1986; Turner, 1982). Additionally, perceivers of a group generally assume that individual group members' beliefs and characteristics can be inferred from their group's decisions and general characteristics (Forsyth, 1999). To the extent to which MMs see the TMT as a group and identify with being a 'middle manager' themselves, these basic human tendencies should make it likely that MMs will classify their interactions with a TMT member primarily in terms of a 'representative of the TMT' rather than as a manager acting on his or her own behalf.

\section{Implications for Research and Practice}

Although the interface model as presented here is grounded in existing theories and the proposed relationships are based on previous empirical studies, the model as such is new and comprises relationships that have not been tested before. Although the interface model may be of value for further theory development, we see its ultimate contribution to the TMT literature in the empirical test. Therefore, we encourage researchers interested in TMT impact on their organizations to incorporate the interface mechanisms and the TMT and MM related determinants in their research designs. According to our model, this should result in higher explained variance of organizational performance and in more consistent relationships between TMT composition, internal processes, and performance.

We encourage researchers to use qualitative and quantitative techniques to further specify the practices of the interface mechanisms. We have posited that information exchange and mutual influencing are expressed in observable behaviors and could thus be studied by researchers with observational techniques. Such methods could result in a detailed set of activities describing the interaction between TMT and MMs that could serve as the base for designing questionnaires. Further insight in the mechanisms from the perspectives of the participants could then be gained by distributing the questionnaires to TMTs and MMs. This also allows for an exploration of potential discrepancies in experiences between both parties. A subsequent step is then to link measures of the interface mechanisms to decision quality, implementation, and, ultimately, organizational performance.

We would also be particularly interested in further conceptual and empirical work on the concept of TMT leadership style, as well as MM follower style. As we indicated before, a growing interest seems to exist in leadership research toward understanding 'shared' leadership (Ensley et al., 2006; Ensley et al., 2003; O'Toole et al., 2002). However, this research does not address how a team of managers collectively leads others in the organization. Yet, we can expect that such TMT collective leadership can be particularly challenging as it requires awareness, insight, and appreciation of one's own, one's co-leader's, and the collective leadership styles. As indicated by a previous qualitative account of sensemaking about leadership (Raes et al., 2007), such sensemaking and coordinating for action is a challenging cognitive and behavioral endeavor. As leadership by teams instead of single managers seems to be increasingly common (Wageman et al., 2008), we would be interested in an assessment of the common and best practices of TMT collective leadership.

A further avenue beyond the direct implications of the interface model might be to assess TMT leadership toward other organizational actors. Although we see the relationship between TMT and 
MMs as particularly important, as MMs translate strategic decisions to the rest of the organization for implementation and because of their sensemaking function vis-à-vis their subordinates (Currie \& Procter, 2005; Floyd \& Wooldridge, 1992; Sims, 2003), MMs are not the only stakeholder group that is of possible interest. TMTs generally have many contacts and stakeholders both inside and outside the organization, such as financial institutions, suppliers, and competitors (Collins \& Clark, 2003). It might be interesting, to see if the content and consistency of TMT leadership actions are also related to TMT impact on shareholders, the board of directors, or employees lower in the organization, etc.

From a practice perspective, our model implies that those involved in recruiting, consulting, or training TMTs for increasing their organizational impact should consider an additional dimension: TMT collective leadership toward MMs and others. Much scientific research and practice efforts have focused on achieving a TMT composition that is somehow 'right' for the organization, industry, and specific circumstances (Hambrick, 2007; Hambrick \& Mason, 1984). In a similar vein, research has focused on how TMTs could best use the knowledge and skills from their members during TMT strategy making (Dooley \& Fryxell, 1999) and there is much practical consideration from trainers and consultants involved in team coaching that have focused on achieving 'good' TMT internal processes (Edmondson \& Smith, 2006). However, the empirical effects of both TMT composition and internal processes on organizational performance are currently inconclusive. The proposition of the interface model is that much insight can be gained from examining the interface mechanisms by which TMT and MMs work together to enhance organizational performance. As it is the pattern of relationships within organizations, not the fact that 'great men' sit at the top of them, that makes it possible to influence and enhance organizational performance (Weick, 1979), the managers, consultants, or trainers interested in understanding the impact of TMTs on their organizations' performance, would benefit from taking into account TMT leadership toward MMs.

\section{Conclusion}

Researchers have emphasized the need for exploring the 'black box' of TMT composition organizational performance relationships (Lawrence, 1997; Priem et al., 1999). Yet, they have paid almost exclusive attention to those processes that are internal to the TMT, such as interaction processes and emergent states (Kilduff, Angelmar, \& Mehra, 2000; Smith et al., 1994). However, to fully understand how a TMT influences organizational performance, another aspect of that black box needs to be understood: the way in which a TMT exerts influence on MMs to make sure that strategic decisions are implemented and acted upon. We contend that understanding the interface of TMT and MMs is crucial for our knowledge of how TMTs influence their organizations. The proposed interface model is theoretically relevant, because it illuminates part of the gap in the causal chain between TMT composition and organizational performance. Practically, such a model can benefit TMTs, because the mechanisms by which TMTs exert influence might be easier to change and to learn for a TMT than aspects of TMT composition. All in all, we urge TMT researchers to start thinking outside the box and to examine how what happens inside the boardroom translates into what happens outside. 
- 146 - 


\section{References}

Amabile, T. M., Barsade, S. G., Mueller, J. S., \& Staw, B. M. (2005). Affect and creativity at work. Administrative Science Quarterly, 50, 367-403.

Amabile, T. M., Schatzel, E. A., Moneta, G. B., \& Kramer, S. J. (2004). Leader behaviors and the work environment for creativity: Perceived leader support. Leadership Quarterly, 15, 5-32.

Amason, A. C. (1996). Distinguishing the effects of functional and dysfunctional conflict on strategic decision making: Resolving a paradox for top management teams. Academy of Management Journal, 39, 123-148.

Amason, A. C., \& Mooney, A. C. (1999). The effects of past performance on top management team conflict in strategic decision making. International Journal of Conflict Management, 10 , 340-359.

Amason, A. C., \& Sapienza, H. J. (1997). The effect of top management team size and interaction norms on cognitive and affective conflict. Journal of Management, 23, 495-516.

Ancona, D. G. (1989). Top management teams: Preparing for the revolution. In J. Carroll (Ed.), Social Psychology in Business Organizations (pp. 99-128). Hillsdale, NJ: Lawrence Erblaum.

Ancona, D. G., \& Bresman, H. (2007). X-teams: How to build teams that lead, innovate, and succeed. Boston, MA: Harvard Business School Press.

Ancona, D. G., \& Caldwell, D. F. (1992). Bridging the boundary: External activity and performance in organizational teams. Administrative Science Quarterly, 37, 634-661.

Ancona, D. G., Goodman, P. S., Lawrence, B. S., \& Tushman, M. L. (2001). Time: A new research lens. Academy of Management Review, 26, 645-563.

Ancona, D. G., Okhuysen, G. A., \& Perlow, L. A. (2001). Taking time to integrate temporal research. Academy of Management Review, 26, 512-529.

Anderson, C. A., Lepper, M. R., \& Ross, L. (1980). Perseverance of social theories: The role of explantion in the persistence of discredited information. Journal of Personality and Social Psychology, 39, 1037-1049.

Argyris, C. (1999). On organizational learning. Malden, MA: Blackwell.

Armstrong, M. (1999). Managing activities. London: CIPD House.

Arrow, H., McGrath, J. E., \& Berdahl, J. L. (2000). Small groups as complex systems: Formation, coordination, development, and adaptation. Thousand Oaks, CA: Sage Publications, Inc.

Bachiochi, P. D. \& Weiner, S. P. (2002). Qualitative data collection and analysis. In S. Rogelberg, (Ed.) Handbook of research methods on industrial and organizational psychology (pp. 161183). Malden, MA: Blackwell Publishing.

Bales, R. F. (1950). Interaction process analysis: A method for the study of small groups. Reading, MA: Addison-Wesley. 
Balkundi, P., \& Harrison, D. A. (2006). Ties, leaders, and time in teams: Strong inference about network structure's effects on team viability and team performance. Academy of Management Journal, 49, 49-68.

Balogun, J., \& Johnson, G. (2004). Organizational restructuring and middle manager sensemaking. Academy of Management Journal, 47, 523-549.

Barrick, M. R., Bradley, B. H., Kristof-Brown, A. L., \& Colbert, A. E. (2007). The moderating role of top management team interdependence: Implications for real teams and working groups. Academy of Management Journal, 50, 544-557.

Barsade, S. G., Ward, A. J., Turner, J. D. F., \& Sonnenfeld, J. A. (2000). To your heart's content: A model of affective diversity in top management teams. Administrative Science Quarterly, 45, 802-836.

Biddle, B. J. (1986). Recent developments in role theory. Annual Review of Sociology, 12, 67-92.

Bliese, P. D. (2000). Within-group agreement, non-independence, and reliability: Implications for data aggregation and analysis. In K. J. Klein \& S. W. J. Kozlowski (Eds.), Multilevel theory, research, and methods in organizations: Foundations, extensions, and new directions. San Francisco, CA: Jossey-Bass.

Boal, K. B., \& Hooijberg, R. (2000). Strategic leadership research: Moving on. Leadership Quarterly, 11, 515-549.

Brehm, S. S., Kassin, S. M., \& Fein, S. (1999). Social psychology. Boston, MA: Houghton Mifflin Company.

Brodbeck, F. C., Frese, M., Akerblom, S., Audia, G., Bakacsi, G., Bendova, H., et al. (2000). Cultural variation of leadership prototypes across 22 European countries. Journal of Occupational and Organizational Psychology, 73, 1-29.

Brodbeck, F. C., Kerschreiter, R., Mojzisch, A., \& Schulz-Hardt, S. (2007). Group decision making under conditions of distributed knowledge: The information asymmetries model. Academy of Management Review, 32, 459-479.

Brower, H. H., Lester, S. W., Korsgaard, M. A., \& Dineen, B. R. (2008). A closer look at trust between managers and subordinates: Understanding the effects of both trusting and being trusted on subordinate outcomes. Journal of Management, forthcoming.

Brown, M. E., \& Gioia, D. A. (2002). Making things click: Distributive leadership in an online division of an offline organization. Leadership Quarterly, 13, 397-419.

Brown, M. E., \& Treviño, L. K. (2006). Ethical leadership: A review and future directions. Leadership Quarterly, 17, 595-616.

Bunderson, J. S. (2003). Team member functional background and involvement in management teams: Direct effects and the moderating role of power centralization. Academy of Management Journal, 46, 458-474.

Bunderson, J. S., \& Sutcliffe, K. M. (2003). Management team learning orientation and business unit performance. Journal of Applied Psychology, 88, 552-560.

Byrne, B. M. (1998). Structural equation modeling with LISREL, PRELIS, and SIMPLIS: Basic concepts, applications, and programming. Mahwah, NJ: Lawrence Erlbaum Associates. 
Cameron, K. S. (1986a). Effectiveness as paradox: Consensus and conflict in conceptions of organizational effectiveness. Management Science, 32, 539-553.

Cameron, K. S. (1986b). A study of organizational effectiveness and its predictors. Management Science, 32, 87-112.

Cannella, A. A., Jr., \& Holcomb, T. R. (2005). A multi-level analysis of the upper-echelons model. Multi-Level Issues in Strategy and Methods, 4, 197-237.

Cannella, A. A., Jr. \& Monroe, M. J. (1997). Contrasting perspectives on strategic leaders: Toward a more realistic view of top managers. Journal of Management, 23, 213-237.

Carmeli, A., \& Schaubroeck, J. (2006). Top management team behavioral integration, decision quality, and organizational decline. Leadership Quarterly, 17, 441-453.

Carmeli, A., \& Tishler, A. (2006). The relative importance of the top management team's managerial skills. International Journal of Manpower, 27, 9-36.

Carpenter, M. A., Geletkanycz, M. A., \& Sanders, W. G. (2004). Upper echelons research revisited: Antecedents, elements, and consequences of top management team composition. Journal of Management, 30, 749-778.

Certo, S. T., Lester, R. H., Dalton, C. M., \& Dalton, D. R. (2006). Top management teams, strategy and financial performance: A meta-analytic examination. Journal of Management Studies, 43, 813-839.

Cha, S., \& Edmondson, A. C. (2006). When values backfire: Leadership, attribution, and disenchantment in a values-driven organization. Leadership Quarterly, 17, 57-78.

Chang, A., Bordia, P., \& Duck, J. (2003). Punctuated equilibrium and linear progression: Toward new understanding of group development. Academy of Management Journal, 46, 106117.

Chen, G., Liu, C., \& Tjosvold, D. (2005). Conflict management for effective top management teams and innovation in China. Journal of Management Studies, 42, 277-300.

Clegg, S. R., Courpasson, D. \& Phillips, N. (2006). Power in organizations. Thousand Oaks, CA: Sage.

Cohen, S. G., \& Bailey, D. E. (1997). What makes team work: Group effectiveness research from the shop floor to the executive suite. Journal of Management, 23, 239-290.

Collins, C. J., \& Clark, K. D. (2003). Strategic human resource practices, top management team social networks, and firm performance: the role of human resource practices in creating organizational competitive advantage. Academy of Management Journal, 46, 740-751.

Connolly, T., Conlon, E., \& Deutsch, S. J. (1980). Organizational effectiveness: A multipleconstituency approach. Academy of Management Review, 5, 211-217.

Coombs, J. E., \& Gilley, K. M. (2005). Stakeholder management as a predictor of CEO compensation: Main effects and interactions with financial performance. Strategic Management Journal, 26, 827-840.

Costa, A. C., Roe, R. A., \& Taillieu, T. (2001). Trust within teams: The relation with performance effectiveness. European Journal of Work and Organizational Psychology, 10, 225-244.

Currie, G., \& Procter, S. J. (2005). The antecedents of middle managers' strategic contribution: The case of a professional bureaucracy. Journal of Management Studies, 42, 1325-1356. 
Cyert, R. M., \& March, J. G. (1963). A behavioral model of the firm. Englewood Cliffs, NJ: Prentice Hall.

Davis, A. \& Rothstein, H. (2006). The effects of the perceived behavioral integrity of managers on employee attitudes: A meta-analysis. Journal of Business Ethics, 67, 407-419

De Dreu, C. K. W., \& Beersma, B. (2005). Conflict in organizations: Beyond effectiveness and performance. European Journal of Work and Organizational Psychology, 14, 105-117.

De Dreu, C. K. W., \& Weingart, L. R. (2003). Task versus relationship conflict, team performance, and team member satisfaction: A meta-analysis. Journal of Applied Psychology, 88, 741749.

De Jong, B. A. \& Elfring, T. (2007). Mediated and differential effects of trust on performance: A study of ongoing work teams. Academy of Management Proceedings.

Den Hartog, D. N., House, R. J., Hanges, P. J., Ruiz-Quintanilla, S. A., \& Dorfman, P. W. (1999). Culture specific and cross-culturally generalizable implicit leadership theories: Are attributes of charismatic/transformational leadership universally endorsed? Leadership Quarterly, 10, 219-256.

Denison, D. R., Hooijberg, R., \& Quinn, R. E. (1995). Paradox and performance: Toward a theory of behavioral complexity in managerial leadership. Organization Science, 6, 524-540.

Dickson, M. W., Den Hartog, D. N., \& Mitchelson, J. K. (2003). Research on leadership in a crosscultural context: Making progress, and raising new questions. Leadership Quarterly, 14, 729-768.

Dickson, M. W., Resick, C. J., \& Hanges, P. J. (2006). Systematic variation in organizationallyshared cognitive prototypes of effective leadership based on organizational form. Leadership Quarterly, 17, 487-505.

Dirks, K. T. (1999). The effects of interpersonal trust on work group performance. Journal of Applied Psychology, 84, 445-455.

Dirks, K. T., \& Ferrin, D. L. (2002). Trust in leadership: Meta-analytic findings and implications for research and practice. Journal of Applied Psychology, 87, 611-628.

Dooley, R. S., \& Fryxell, G. E. (1999). Attaining decision quality and commitment from dissent: The moderating effects of loyalty and competence in strategic decision-making teams. Academy of Management Journal, 42, 389-402.

Dooley, R. S., Fryxell, G. E., \& Judge, W. Q. (2000). Belaboring the not-so-obvious: Consensus, commitment, and strategy implementation speed and success. Journal of Management, 26, 1237-1257.

Dopson, S., Risk, A., \& Stewart, R. (1992). The changing role of the middle manager in the United Kingdom. International Studies of Management and Organization, 22, 40-53.

Dutton, J. E., \& Ashford, S. J. (1993). Selling issues to top management. Academy of Management Review, 18, 397-428.

Dutton, J. E., Ashford, S. J., O'Neill, R. M., Hayes, E., \& Wierba, E. E. (1997). Reading the wind: How middle managers assess the context for selling issues to top managers. Strategic Management Journal, 18, 407-423. 
Edmondson, A. C. (1999). Psychological safety and learning behavior in work teams. Administrative Science Quarterly, 44, 350-383.

Edmondson, A. C., \& McManus, S. E. (2007). Methodological fit in management field research. Academy of Management Review, 32, 1155-1179.

Edmondson, A. C., Roberto, M. A., \& Watkins, M. D. (2003). A dynamic model of top management team effectiveness: Managing unstructured task streams. Leadership Quarterly, 14, 297325.

Edmondson, A. C., \& Smith, D. M. (2006). Too hot to handle? How to manage relationship conflict. California Management Review, 49(1), 6-31.

Eisenhardt, K. M. (1989). Agency theory: An assessment and review. Academy of Management Review, 14, 57-74.

Eisenhardt, K. M., \& Bourgeois, L. J. (1988). Politics of strategic decision-making in high-velocity environments: Toward a midrange theory. Academy of Management Journal, 31, 737770 .

Eisenhardt, K. M., Kahwajy, J. L., \& Bourgeois, L. J. (1997). Conflict and strategic choice: How top management teams disagree. California Management Review, 39(2), 42-62.

Elron, E. (1997). Top management teams within multinational corporations: Effects of cultural heterogeneity. Leadership Quarterly, 8, 393-412.

Ensley, M. D., Hmieleski, K. M., \& Pearce, C. L. (2006). The importance of vertical and shared leadership within new venture top management teams: Implications for the performance of startups. Leadership Quarterly, 17, 217-231.

Ensley, M. D., \& Pearce, C. L. (2001). Shared cognition in top management teams: Implications for new venture performance. Journal of Organizational Behavior, 22, 145-160.

Ensley, M. D., Pearson, A. W., \& Amason, A. C. (2002). Understanding the dynamics of new venture top management teams: Cohesion, conflict, and new venture performance. Journal of Business Venturing, 17, 365-386.

Ensley, M. D., Pearson, A., \& Pearce, C. L. (2003). Top management team process, shared leadership, and new venture performance: $A$ theoretical model and research agenda. Human Resource Management Review, 13, 329-346.

Epitropaki, O., \& Martin, R. (2005). From ideal to real: A longitudinal study of the role of implicit leadership theories on leader-member exchanges and employee outcomes. Journal of Applied Psychology, 90, 659-676.

Ericksen, J., \& Dyer, L. (2004). Right from the start: Exploring the effects of early team events on subsequent project team development and performance. Administrative Science Quarterly, 49, 438-471.

Farrell, J. B., Flood, P. C., Mac Curtain, S., Hannigan, A., Dawson, J., \& West, M. (2005). CEO leadership, top team trust and the combination and exchange of information. Irish Journal of Management, 26, 22-40.

Finkelstein, S. (1992). Power in top management teams: Dimensions, measurement, and validation. Academy of Management Journal, 35, 505-538. 
Finkelstein, S., \& Hambrick, D. C. (1990). Top-management-team tenure and organizational outcomes: The moderating role of managerial discretion. Administrative Science Quarterly, $35,484-503$

Finkelstein, S., \& Hambrick, D. C. (1996). Strategic leadership: Top executives and their effects on organizations. St. Paul, MN: West Publishing Company.

Flood, P. C., Hannan, E., Smith, K. G., Turner, T., West, M. A., \& Dawson, J. (2000). Chief executive leadership style, consensus decision making, and top management team effectiveness. European Journal of Work and Organizational Psychology, 9, 401-420.

Floyd, S. W., \& Lane, P. J. (2000). Strategizing throughout the organization: Managing role conflict in strategic renewal. Academy of Management Review, 25, 154-177.

Floyd, S. W., \& Wooldridge, B. (1992). Middle management involvement in strategy and its association with strategic type: A research note. Strategic Management Journal, 13, 153167.

Floyd, S. W., \& Wooldridge, B. (1997). Middle management's strategic influence and organizational performance. Journal of Management Studies, 34, 465-485.

Forbes, D. P., \& Milliken, F. J. (1999). Cognition and corporate governance: Understanding boards of directors as strategic decision-making groups. Academy of Management Review, 24, 489-505.

Forsyth, D. R. (1999). Group dynamics (3rd ed.). Belmont, CA: Wadsworth Publishing Company.

Freeman, R. E., \& Reed, D. L. (1983). Stockholders and stakeholders: A new perspective on corporate governance. California Management Review, 25 (3), 88-106.

George, J. M. (1990). Personality, affect, and behavior in groups. Journal of Applied Psychology $75,107-116$.

Gersick, C. J. G. (1988). Time and transition in work groups: Toward a new model of group development. Academy of Management Journal, 31, 9-41.

Gersick, C. J. G. (1989). Marking time: Predictable transitions in task groups. Academy of Management Journal, 32, 274-309.

Gersick, C. J. G. (1991). Revolutionary change theories: A multi-level exploration of the punctuated equilibrium paradigm. Academy of Management Review, 16, 10-36.

Gibson, D. E., \& Schroeder, S. J. (2003). Who ought to be blamed? The effects of organizational roles on blame and credit attributions. International Journal of Conflict Management, 14, 95-117.

Gibson, C. B., \& Zellmer-Bruhn, M. E. (2001). Metaphors and meaning: An intercultural analysis of the concept of teamwork. Administrative Science Quarterly, 46, 274-303.

Gioia, D. A., \& Thomas, J. B. (1996). Identity, image, and issue interpretation: Sensemaking during strategic change in academia. Administrative Science Quarterly, 41, 370-403.

Glunk, U., Heijltjes, M. G., \& Olie, R. (2001). Design characteristics and functioning of top management teams in Europe. European Management Journal, 19, 291-300.

Guth, W. D., \& MacMillan, I. C. (1986). Strategy implementation versus middle management selfinterest. Strategic Management Journal, 7, 313-327. 
Hackman, J. R. (1987). The design of work teams. In J. Lorsch (Ed.), Handbook of organizational behavior (pp. 315-342). Englewood Cliffs, NJ: Prentice-Hall.

Hackman, J. R. (2002). Leading teams: Setting the stage for great performances. Boston, MA: Harvard Business School Press.

Hair, J. F., Anderson, R. E., Tatham, R. L., \& Black, W. C. (1995). Multivariate data analysis (4th ed.). Englewood Cliffs, NJ: Prentice Hall.

Haleblian, J., \& Finkelstein, S. (1993). Top management team size, CEO dominance, and firm performance: The moderating roles of environmental turbulence and discretion. Academy of Management Journal, 36, 844-863.

Hambrick, D. C. (1994). Top management groups: A conceptual integration and reconsideration of the "team" label. Research in Organizational Behavior, 16, 171-213.

Hambrick, D. C. (2007). Upper echelons theory: An update. Academy of Management Review, 32, 334-343.

Hambrick, D. C., \& D'Aveni, R. A. (1992). Top team deterioration as a part of the downward spiral of large corporate bankruptencies. Management Science, 38, 1445-1466.

Hambrick, D. C., \& Mason, P. A. (1984). Upper echelons: The organization as a reflection of its top managers. Academy of Management Review, 9, 193-206.

Hanges, P. J., \& Dickson, M. W. (2004). The development and validation of the GLOBE culture and leadership scales. In R. J. House, P. J. Hanges, M. Javidan, P. Dorfman \& V. Gupta (Eds.), Culture, leadership, and organizations: The GLOBE study of 62 societies. Thousand Oaks, CA: Sage Publications.

Harrison, D. A., Price, K. H., \& Bell, M. P. (1998). Beyond relational demography: Time and the effects of surface- and deep-level diversity on work group cohesion. Academy of Management Journal, 41, 96-107.

Harrison, D. A., Price, K. H., Gavin, J. H., \& Florey, A. T. (2002). Time, teams, and task performance: Changing effects of surface- and deep-level diversity on group functioning. Academy of Management Journal, 45, 1029-1045.

Heijltjes, M. G., Olie, R., \& Glunk, U. (2003). Internationalization of top management teams in Europe. European Management Journal, 21, 89-97.

Hendriks, W. (2004). Top management team diversity and firm performance: An empirical study on Belgian and Dutch IT firms. Maastricht: Universiteit Maastricht.

Hickson, D. J., Miller, S. J., \& Wilson, D. C. (2003). Planned or prioritized? Two options in managing the implementation of strategic decisions. Journal of Management Studies, 40 , 1803-1836.

Hinkin, T. R. (1998). A brief tutorial on the development of measures for use in survey questionnaires. Organizational Research Methods, 1, 104-121.

Hofmann, D. A. (2004). Issues in multilevel research: Theory, development, measurement, and analysis. In S. G. Rogelberg (Ed.), Handbook of research methods in industrial and organizational psychology. Malden, MA: Blackwell Publishing.

Hofstede, G. (2001). Culture's consequences: Comparing values, behaviors, institutions, and organizations across nations. London: Sage. 
Hooijberg, R., \& Choi, J. (2000). Which leadership roles matter to whom? An examination of rater effects on perceptions of effectiveness. Leadership Quarterly, 11, 341-364.

Hooijberg, R., Hunt, J. G., \& Dodge, G. E. (1997). Leadership complexity and development of the leaderplex model. Journal of Management, 23, 375-408.

laquinto, A. L., \& Fredrickson, J. W. (1997). Top management team agreement about the strategic decision process: A test of some of its determinants and consequences. Strategic Management Journal, 18, 63-75.

Ilgen, D. R., Hollenbeck, J. R., Johnson, M., \& Jundt, D. (2005). Teams in organizations: From input-process-output models to IMOI models. Annual Review of Psychology, 56, 517-543.

James, L. R., Demaree, R. G., \& Wolf, G. (1984). Estimating within-group interrater reliability with and without response bias. Journal of Applied Psychology, 69, 85-98.

Janis, I. L. (1982). Groupthink: Psychological studies of policy decisions and fiascos (2nd ed.). Boston, MA: Houghton Mifflin.

Janssen, O., Van de Vliert, E., \& Veenstra, C. (1999). How task and person conflict shape the role of positive interdependence in management teams. Journal of Management, 25, 117-141.

Jarzabkowski, P., \& Searle, R. H. (2004). Harnessing diversity and collective action in the top management team. Long Range Planning, 37, 399-419.

Jarzabkowski, P., \& Wilson, D. C. (2002). Top teams and strategy in a UK university. Journal of Management Studies, 39, 355-381.

Jehn, K. A. (1995). A multimethod examination of the benefits and detriments of intragroup conflict. Administrative Science Quarterly, 40, 256-282.

Jehn, K. A., \& Mannix, E. A. (2001). The dynamic nature of conflict: A longitudinal study of intragroup conflict and group performance. Academy of Management Journal, 44, 238251.

Jones, G. R., \& George, J. M. (1998). The experience and evolution of trust: Implications for cooperation and teamwork. Academy of Management Review, 23, 531-546.

Kaplan, R. S., \& Norton, D. P. (1992). The balanced scorecard - measures that drive performance. Harvard Business Review, 70 (1), 71-79.

Kaplan, R. S., \& Norton, D. P. (1993). Putting the balanced scorecard to work. Harvard Business Review, 71 (5), 134-147.

Katz, D., \& Kahn, R. L. (1978). The social psychology of organizations (2nd ed.). New York, NJ: John Wiley \& Sons.

Keller, T. (2003). Parental images as a guide to leadership sensemaking: An attachment perspective on implicit leadership theories. Leadership Quarterly, 14, 141-160.

Kelley, H. H. (1973). The processes of causal attribution. American Psychologist, 28, 107-128.

Kelley, R. E. (1992). The power of followership: How to create leaders people want to follow and followers who lead themse/ves. New York, NY: Doubleday/Currency.

Kets de Vries, M. F. R. (2005). Leadership group coaching in action: The zen of creating high performance teams. Academy of Management Executive, 19(1), 61-76.

Kilduff, M., Angelmar, R., \& Mehra, A. (2000). Top management team diversity and firm performance: Examining the role of cognitions. Organization Science, 11, 21-34. 
Kim, W. C., \& Mauborgne, R. A. (1993). Procedural justice, attitudes, and subsidiary top management team compliance with multinationals' corporate strategic decisions. Academy of Management Journal, 36, 502-526.

Klenke, K. (2003). Gender influences in decision-making processes in top management teams. Management Decision, 41, 1024-1034.

Knight, D., Pearce, C. L., Smith, K. G., Olian, J. D., Sims, H. P., Smith, K. A., et al. (1999). Top management team diversity, group process, and strategic consensus. Strategic Management Journal, 20, 445-465.

Korsgaard, M. A., Schweiger, D. M., \& Sapienza, H. J. (1995). Building commitment, attachment, and trust in strategic decision-making teams: The role of procedural justice. Academy of Management Journal, 38, 60-84.

Langfred, C. W. (2004). Too much of a good thing? Negative effects of high trust and individual autonomy in self-managing teams. Academy of Management Journal, 47, 385-399.

Langfred, C. W. (2007). The downside of self-management: A longitudinal study of the effects of conflict on trust, autonomy, and task interdependence in self-managing teams. Academy of Management Journal, 50, 885-900.

Lawler, E. E. (1994). Motivation in work organizations. San Fransisco, CA: Jossey-Bass.

Lawrence, B. S. (1997). The black box of organizational demography. Organization Science, 8, 122.

Leifer, R., \& Mills, P. K. (1996). An information processing approach for deciding upon control strategies and reducing control loss in emerging organizations. Journal of Management, 22, 113-137.

LePine, J. A., Piccolo, R. F., Jackson, C. L., Mathieu, J. E., \& Saul, J. R. (2008). A meta-analysis of teamwork processes: Tests of a multi-level model and relationships with team effectiveness criteria. Personnel Psychology, 61, 273-307

Lewicki, R. J., Tomlinson, E. C., \& Gillespie, N. (2006). Models of interpersonal trust development: Theoretical approaches, empirical evidence, and future directions. Journal of Management, 32, 991-1022.

Li, J., \& Hambrick, D. C. (2005). Factional groups: A new vantage on demographic faultlines, conflict, and disintegration in work teams. Academy of Management Journal, 48, 794-813.

Lindsley, D. H., Brass, D. J., \& Thomas, J. B. (1995). Efficacy-performing spirals: A multilevel perspective. Academy of Management Review, 20, 645-678.

Lubatkin, M. H., Simsek, Z., Yan, L., \& Veiga, J. F. (2006). Ambidexterity and performance in small- to medium-sized firms: The pivotal role of top management team behavioral integration. Journal of Management, 32, 646-672.

Maitlis, S. (2005). The social processes of organizational sensemaking. Academy of Management Journal, 48, 21-49.

Malle, B. F., \& Knobe, J. (1997). Which behaviors do people explain? A basic actor-observer asymmetry. Journal of Personality and Social Psychology, 72, 288-304.

March, J. G., \& Simon, H. A. (1958). Organizations. New York, NY: Wiley. 
Marks, M. A., Mathieu, J. E., \& Zaccaro, S. J. (2001). A temporal based framework and taxonomy of team processes. Academy of Management Review, 26, 356-376.

Martinko, M. J., Harvey, P., \& Douglas, S. C. (2007). The role, function, and contribution of attribution theory to leadership: A review. Leadership Quarterly, 18, 561-585.

Mayer, R. C., Davis, J. H., \& Schoorman, F. D. (1995). An integrative model of organizational trust. Academy of Management Review, 20, 709-734.

Mayer, R. C., \& Gavin, M. B. (2005). Trust in management and performance: Who minds the shop while the employees watch the boss? Academy of Management Journal, 48, 874-888.

McAllister, D. J. (1995). Affect- and cognition-based trust as foundations for interpersonal cooperation in organizations. Academy of Management Journal, 38, 24-59.

McGrath, J. E. (1964). Social psychology: A brief introduction. New York, NY: Holt, Rinehart and Winston.

McGrath, J. E. (1984). Groups: Interaction and performance. Engelwood Cliffs, NJ: Prentice-Hall.

McGrath, J. E., Arrow, H., \& Berdahl, J. L. (2000). The study of groups: Past, present, and future. Personality and Social Psychology Review, 4, 95-105.

McGrath, J. E., \& Tschan, F. (2004). Temporal matters in social psychology: Examining the role of time in lives of groups and individuals. Washington: American Psychological Association.

McKnight, D. H., Cummings, L. L., \& Chervany, N. L. (1998). Initial trust formation in new organizational relationships. Academy of Management Review, 23, 473-490.

Milliken, F. J., \& Martins, L. L. (1996). Searching for common threads: Understanding the multiple effects of diversity in organizational groups. Academy of Management Review, 21, 402433.

Mintzberg, H. (1973). The nature of managerial work. New York, NY: Harper \& Row.

Mintzberg, H. (1983). Structure in fives. Englewood Cliffs, NJ: Prentice-Hall.

Nunnally, J. C. (1978). Psychometric theory (2nd ed.). New York, NY: McGraw-Hill.

Nutt, P. C. (1986). Tactics of implementation. Academy of Management Journal, 29, 230-261.

Nutt, P. C. (1999). Surprising but true: Half the decisions in organizations fail. Academy of Management Executive, 13 (4), 75-90.

Olson, B. J., Parayitam, S., \& Bao, Y. (2007). Strategic decision making: The effects of cognitive diversity, conflict, and trust on decision outcomes. Journal of Management, 33, 196-222.

O'Reilly, C. A., Caldwell, D. F., \& Barnett, W. P. (1989). Work group demography, social integration, and turnover. Administrative Science Quarterly, 34, 21-37.

O'Toole, J., Galbraith, J., \& Lawler III, E. E. (2002). When two (or more) heads are better than one: The promises and pitfalls of shared leadership. California Management Review, 44 (4), 6583.

Parry, K. W., \& Proctor-Thomson, S. B. (2002). Perceived integrity of transformational leaders in organisational settings. Journal of Business Ethics, 35, 75-96.

Peck, S., \& Ruigrok, W. (2000). Hiding behind the flag? Prospects for change in German corporate governance. European Management Journal, 18, 420-430.

Pelled, L. H., Eisenhardt, K. M., \& Xin, K. R. (1999). Exploring the black box: An analysis of work group diversity, conflict, and performance. Administrative Science Quarterly, 44, 1-28. 
Peterson, R. S. (1997). A directive leadership style in group decision making can be both virtue and vice: Evidence from elite and experimental groups. Journal of Personality and Social Psychology, 72, 1107-1121.

Peterson, R. S., \& Behfar, K. J. (2003). The dynamic relationship between performance feedback trust, and conflict in groups: A longitudinal study. Organizational Behavior and Human Decision Processes, 92, 102-112.

Peterson, R. S., Owens, P. D., Tetlock, P. E., Fan, E. T., \& Martorana, P. (1998). Group dynamics in top management teams: Groupthink, vigilance, and alternative models of organizational failure and success. Organizational Behavior and Human Decision Processes, 73, 272-305.

Peterson, R. S., Smith, D. B., Martorana, P. V., \& Owens, P. D. (2003). The impact of chief executive officer personality on top management team dynamics: One mechanism by which leadership affects organizational performance. Journal of Applied Psychology, 88, 795808.

Pettigrew, A. M. (1992). On studying managerial elites. Strategic Management Journal, 13, 163182.

Pitcher, P., \& Smith, A. D. (2001). Top management team heterogeneity: Personality, power, and proxies. Organization Science, 12, 1-18.

Podsakoff, P. M., MacKenzie, S. B., Lee, J.-Y., \& Podsakoff, N. P. (2003). Common method biases in behavioral research: A critical review of the literature and recommended remedies. Journal of Applied Psychology, 88, 879-903.

Post, J. E., Preston, L. E., \& Sachs, S. (2002). Managing the extended enterprise: The new stakeholder view. California Management Review, 45(1), 6-28.

Priem, R. L., Lyon, D. W., \& Dess, G. G. (1999). Inherent limitations of demographic proxies in top management team heterogeneity research. Journal of Management, 25, 935-953.

Pye, A. (2005). Leadership and organizing: Sensemaking in action. Leadership, 1, 21-40.

Raelin, J. A. (1993). The Persean ethic: Consistency of belief and action in managerial practice. Human Relations, 46, 575-622.

Raes, A. M. L., Glunk, U., Heijltjes, M., \& Roe, R. A. (2007). Top management team and middle managers: Making sense of leadership. Small Group Research, 38, 360-386.

Rau, D. (2005). The influence of relationship conflict and trust on the transactive memory performance relation in top management teams. Small Group Research, 36, 746-771.

Rau, D. (2006). Top management team transactive memory, information gathering, and perceptual accuracy. Journal of Business Research, 59, 416-424.

Reagans, R., \& Zuckerman, E. W. (2001). Networks, diversity, and productivity: The social capital of corporate R\&D teams. Organization Science, 12, 502-517.

Roberto, M. A. (2003). The stable core and dynamic periphery in top management teams. Management Decision, 41, 120-131.

Robertson, Q. M. (2006). Justice in teams: The activation and role of sensemaking in the emergence of justice climates. Organizational Behavior and Human Decision Processes, 100, 177-192. 
Roe, R. A. (1999). Work performance: A multiple regulation perspective. In G. Cooper \& I. T. Robertson (Eds.), International Review of Work and Organizational Psychology (pp. 231335). Chichester: Wiley.

Roe, R. A. (2005). No more variables, please. Giving time a place in work and organizational psychology. In H. Kepir Sinangil, F. Avallone \& A. Caetano (Eds.), Convivence in organizations and society (pp. 11-20). Milano: Guerini.

Roe, R. A. (2008). Time in applied psychology: Studying what happens rather than what is. The European Psychologist, 13, 37-52.

Ronen, S., \& Shenkar, O. (1985). Clustering countries on attitudinal dimensions: A review and synthesis. Academy of Management Review, 10, 435-454.

Rousseau, D. M., Sitkin, S. B., Burt, R. S., \& Camerer, C. (1998). Not so different after all: A crossdiscipline view of trust. Academy of Management Review, 23, 393-404.

Russell, C. J. (2001). A longitudinal study of top-level executive performance. Journal of Applied Psychology, 86, 560-573.

Samra-Fredericks, D. (2000). Doing 'boards-in-action' research - an ethnographic approach for the capture and analysis of directors' and senior managers' interactive routines. Corporate Governance: An International Review, 8, 244-257.

Schippers, M. C., Den Hartog, D. N., Koopman, P. L., \& Wienk, J. A. (2003). Diversity and team outcomes: The moderating effects of outcome interdependence and group longevity and the mediating effect of reflexivity. Journal of Organizational Behavior, 24, 779-802.

Schneider, M. (2002). A stakeholder model of organizational leadership. Organization Science, 13, 209-220.

Senge, P. M. (1990). The fifth discipline: The art and the practice of the learning organization. New York, NY: Currency Doubleday.

Simons, T. (1996). Executive conflict management: Keys to excellent decisions and smooth implementation. Cornell Hotel and Restaurant Administration Quarterly, 37(6), 34-41.

Simons, T. (2002). Behavioral integrity: The perceived alignment between managers' words and deeds as a research focus. Organization Science, 13, 18-35.

Simons, T., Pelled, L. H., \& Smith, K. A. (1999). Making use of difference: Diversity, debate, and decision comprehensiveness in top management teams. Academy of Management Journal, $42,662-673$.

Simons, T. L., \& Peterson, R. S. (2000). Task conflict and relationship conflict in top management teams: The pivotal role of intragroup trust. Journal of Applied Psychology, 85, 102-111.

Sims, D. (2003). Between the millstones: A narrative account of the vulnerability of middle managers' storying. Human Relations, 56, 1195-1211.

Simsek, Z., Veiga, J. F., Lubatkin, M. H., \& Dino, R. N. (2005). Modeling the multilevel determinants of top management team behavioral integration. Academy of Management Journal, 48, 69-84.

Smith, K. G., Smith, K. A., Olian, J. D., Sims, H. P. J., O'Bannon, D. P., \& Scully, J. A. (1994). Top management team demography and process: The role of social integration and communication. Administrative Science Quarterly, 39, 412-438. 
Srivastava, A., Bartol, K. M., \& Locke, E. A. (2006). Empowering leadership in management teams: Effects on knowledge sharing, efficacy, and performance. Academy of Management Journal, 49, 1239-1251.

Staw, B. M. (1975). Attribution of the "causes" of performance: A general alternative interpretation of cross-sectional research on organizations. Organizational Behavior and Human Performance, 13, 414-432.

Steiner, I. D. (1972). Group process and productivity. New York, NY: Academic Press.

Stewart, G. L. (2006). A meta-analytic review of relationships between team design features and team performance. Journal of Management, 32, 29-54.

Stewart, G. L., \& Barrick, M. R. (2000). Team structure and performance: Assessing the mediating role of intrateam process and the moderating role of task type. Academy of Management Journal, 43, 135-148.

Strauss, A., \& Corbin, J. (1998). Basics of qualitative research: Techniques and procedures for developing grounded theory (2nd ed.). Thousand Oaks, CA: Sage Publications.

Tabachnick, B. G., \& Fidell, L. S. (2007). Using multivariate statistics (5th ed.). Boston, MA: Pearson Education.

Tajfel, H., \& Turner, J. (1986). The social identity theory of intergroup behavior. In S. Worchel \& W. C. Austin (Eds.), The social psychology of intergroup relations (pp. 7-24). Chicago, IL: Nelson-Hall.

Tengblad, S. (2006). Is there a 'new managerial work'? A comparison with Henry Mintzberg's classic study 30 years later. Journal of Management Studies, 43, 1437-1461.

Treviño, L. K., Hartman, L. P., \& Brown, M. (2000). Moral person and moral manager: How executives develop a reputation for ethical leadership. California Management Review, 42 (4), 128-142.

Tsui, A. S., Ashford, S. J., Clair, L. S., \& Xin, K. R. (1995). Dealing with discrepant expectations: Response strategies and managerial effectiveness. Academy of Management Journal, 38 , 1515-1543.

Tuckman, B. W. (1965). Developmental sequence in small groups. Psychological Bulletin, 63, 384399.

Tuckman, B. W., \& Jensen, M. A. C. (1977). Stages of small group development revisited. Group and Organizational Studies, 2, 419-427.

Turner, J. (1982). Toward a cognitive redefinition of the social group. In H. Tajfel (Ed.), Social identity and intergroup relations (pp. 15-40). Cambridge, England: Cambridge University Press.

Tversky, A., \& Kahneman, D. (1974). Judgment under uncertainty: Heuristics and biases. Science, 185, 1124-1131.

Vandenberg, R. J., \& Lance, C. E. (2000). A review and synthesis of the measurement invariance literature: Suggestions, practices, and recommendations for organizational research. Organizational Research Methods, 3, 4-70.

Van de Ven, A. H., \& Poole, M. S. (1995). Explaining development and change in organizations. Academy of Management Review, 20, 510-540. 
Van der Vegt, G. S., \& Bunderson, J. S. (2005). Learning and performance in multidisciplinary teams: The importance of collective team identification. Academy of Management Journal, 48, 532-547.

Van Olffen, W., Raes, A. M. L., Blumberg, B. F., \& Chung, Y. (2007). Potential and actual subgroups in teams: Intra-team networks as validation for faultlines. Paper presented at the Academy of Management Annual Meeting, Philadelphia, PA.

Vera, D., \& Crossan, M. (2004). Strategic leadership and organizational learning. Academy of Management Review, 29, 222-240.

Wageman, R., Nunes, D. A., Burruss, J. A., \& Hackman, J. R. (2008). Senior leadership teams: What it takes to make them great. Boston, MA: Harvard Business School Press.

Waller, M. J. (1999). The timing of adaptive group responses to nonroutine events. Academy of Management Journal, 42, 127-137.

Weick, K. E. (1979). The social psychology of organizing (2nd ed.). Reading, MA: Addison-Wesley.

Weick, K. E. (1995). Sensemaking in organizations. Thousand Oaks, CA: Sage.

Weick, K. E., Sutcliffe, K. M., \& Obstfeld, D. (2005). Organizing and the process of sensemaking. Organization Science, 16, 409-421

Weingart, L. R. (1997). How did they do that? The ways and means of studying group process. Research in Organizational Behavior, 19, 189-239.

West, M. A. (1996). Reflexivity and work group effectiveness: A conceptual integration. In M. A. West (Ed.), Handbook of work group psychology (pp. 555-579). Chichester: John Wiley \& Sons Ltd.

West, M. A., \& Anderson, N. R. (1996). Innovation in top management teams. Journal of Applied Psychology, 81, 680-693.

Wilson, J. M., Straus, S. G., \& McEvily, B. (2006). All in due time: The development of trust in computer-mediated and face-to-face teams. Organizational Behavior and Human Decision Processes, 99, 16-33.

Wooldridge, B., \& Floyd, S. W. (1990). The strategy process, middle management involvement, and organizational performance. Strategic Management Journal, 11, 231-241.

Worden, S. (2003). The role of integrity as a mediator in strategic leadership: A recipe for reputational capital. Journal of Business Ethics, 46, 31-44.

Yin, R. K. (2003). Case study research: Design and methods (3rd ed.). Thousand Oaks, CA: Sage.

Yukl, G. (2006). Leadership in organizations (6th ed.). Upper Saddle River, NJ: Pearson Education, Inc.

Zand, D. E. (1972). Trust and managerial problem solving. Administrative Science Quarterly, 17, 229-239. 


\section{Summary}

Top management teams (TMTs) are expected to make a difference for the organizations in which they work. This dissertation addresses the question if and how TMTs actually exert such influence. To better understand this issue, I build on two different theoretical paradigms: upper-echelons theory and psychological research on nonmanagerial teams. To advance knowledge on TMT impact, I use multiple ways of scientific inquiry, among which a literature review, quantitative and qualitative empirical studies, and new theory development.

In the first chapter, a TMT is defined as 'the aggregate informational and decisional entity through which an organization operates and which forms the inner circle of executives who collectively formulate, articulate, and execute the strategic and tactical moves of the organization.' TMT impact is defined as 'the effect that the TMT has on the operation and outcomes of the organization, which can be positive, negative, neutral, or even absent.' The research paradigms are introduced and gaps in current knowledge are identified. I conclude that TMT research should examine the role of TMT internal processes as determinants of TMT impact, as well as explore new determinants through qualitative and longitudinal research.

TMT internal processes describe the nature of team members' interaction and behavior while working on achieving the TMT's goals. Despite widespread interest from TMT researchers in the role of these processes, empirical research is relatively scarce and a clear overview on their effects lacks. To achieve such an overview, we build on recent insights from the team literature to make a distinction between task processes, relationship processes, and emergent states. Using this framework to classify investigated variables, chapter 2 reports a review on empirical studies that measure the relationship between TMT internal processes, emergent states, and outcomes. From this review, the necessity is identified to examine broader patterns of processes and states over longer time periods to complement existing cross-sectional studies on single processes.

In chapter 3, we do just so by examining patterns of task conflict, relationship conflict, and trust in 41 management teams of student associations with five measurement moments over a 10month period. This sample was chosen, as it provides the advantage of a large cohort of teams that started working together at the same moment and in a stable composition for one year. The results indicate that two main patterns exist that characterize the joint evolution of conflict and trust. Half of the teams experienced a stable level of low conflict and high trust, whereas the other half experienced a pattern of increasing conflict and decreasing trust. The teams with the stable pattern were more effective than the teams with the unstable pattern. This study illustrates the insight that can be gained from taking a temporal perspective on team processes, as well as how creative thinking about data collection can lead to unexpected possibilities for longitudinal studies over relatively long periods of time. 
TMT researchers have advocated the use of qualitative and longitudinal approaches to get a 'realistic picture' of how TMTs operate and influence their organizations. Therefore, I entered the boardroom of a Dutch organization and conducted observations of TMT meetings and interviews with individual managers, the results of which are described in chapter 4. Transcripts of the meetings were analyzed with a grounded theory approach with the purpose of building new theory about TMT impact. The issue of TMT sensemaking about leading middle managers turned out to be a recurrent topic of discussion in this TMT. By combining the results from data analysis with existing theories about strategic leadership, sensemaking, and team processes, we propose a model about TMT sensemaking, TMT unity in actions, and actual TMT leadership, in relation to decision implementation and organizational performance.

In chapter 5, the relationship between TMT and middle managers is explored from the perspective of middle managers. This chapter addresses the problem that researchers until now have mainly focused on financial organizational performance as the outcome of TMT impact, while neglecting more proximal indicators of TMT performance. This is problematic, because it can lead to inconsistent findings regarding the effects of TMT internal processes and states on outcomes, as identified in chapter 2. In order to obtain insight in the dimensionality of TMT performance, we build on stakeholder theory and on conceptualizations of team effectiveness in research of nonmanagerial teams that both suggest obtaining stakeholders' evaluations of TMT performance. Analyzing the expectations and evaluations of 251 middle managers - an important group of intra-organizational stakeholders of a TMT - in France and the Netherlands with exploratory and confirmatory factor analyses, a five-dimensional model of TMT performance is proposed, which comprises company results, strategic leadership, connectedness, TMT unity, and moral leadership.

Taking together the findings from chapters 1 to 5 , it seems that the time has come for a new direction in TMT research in which determinants of TMT impact from inside the boardroom - internal processes and states - are complemented by factors from outside: the way in which TMTs lead middle managers. Therefore, chapter 6 presents a new theoretical model of TMT impact, which is called the interface model of TMT and middle managers. This model complements and extends current research on TMT impact and has the potential of generating more detailed explanations and empirical insights on this issue. The two central mechanisms through which the interface model is proposed to work are information exchange and mutual influencing, which are influenced by TMT leadership style and middle managers' follower style.

All in all, this dissertation contributes to understanding the role of TMTs in their organizations by specifying temporal patterns of team internal dynamics and by introducing a focus on TMT leadership of middle managers. By doing that, researchers of TMTs and nonmanagerial teams could formulate more detailed models for TMT impact and possibly resolve current inconsistent findings. Practicing TMTs and consultants could also benefit from the dissertation by considering that TMTs' impact on organizations resides not only inside but also outside the boardroom. 


\section{Samenvatting}

Van een topmanagementteam - in dit proefschrift afgekort als 'TMT' en in het Nederlands vaak aangeduid als 'Raad van Bestuur' - verwacht men dat het een invloed heeft op de organisatie waarin het werkt. In dit proefschrift staat de vraag centraal hoe TMTs dat eigenlijk doen. Ik benader deze vraag vanuit twee verschillende theoretische perspectieven: 'upper echelons' theorie en psychologisch onderzoek naar niet-managementteams. Ook gebruik ik verschillende onderzoeksmethoden - literatuuronderzoek, kwalitatieve en kwantitatieve empirische studies en theorie-ontwikkeling - om zo de wetenschappelijke kennis over TMT impact te vergroten.

In het eerste hoofdstuk wordt een TMT gedefinieerd als 'een collectieve entiteit in een organisatie voor het verwerken van informatie en het nemen van beslissingen, bestaande uit een kleine kring van managers die samen de strategische en tactische beslissingen van een organisatie neemt en uitvoert'. TMT impact is gedefinieerd als 'het effect dat een TMT heeft op het functioneren en de uitkomsten van de organisatie; dit kan positief, negatief, neutraal of afwezig zijn'. Ook worden in dit hoofdstuk de twee verschillende theoretische perspectieven geïntroduceerd en worden lacunes in de huidige wetenschappelijke kennis geïdentificeerd. Ik concludeer in dit hoofdstuk dat toekomstig TMT onderzoek twee dingen zou moeten doen, namelijk de rol van TMT interne processen als determinanten van TMT impact onderzoeken én nieuwe determinanten exploreren door middel van kwalitatieve en longitudinale onderzoeksmethoden.

TMT interne processen beschrijven de aard van de interactie en het gedrag van de teamleden tijdens het werken aan de doelen van het TMT. Veel TMT onderzoekers hebben interesse getoond in de rol van deze processen, maar empirisch onderzoek is nog relatief schaars. Het bestaande onderzoek geeft bovendien geen eenduidig beeld van de effecten van deze processen. Om hierin een beter inzicht te krijgen, gebruiken we - ikzelf en mijn co-auteurs - in hoofdstuk 2 recente kennis uit de teamliteratuur. Op basis daarvan maken we een onderscheid tussen TMT taakprocessen, relatieprocessen en dynamische toestanden. Vervolgens gebruiken we deze indeling om een overzicht te geven van de resultaten van bestaand onderzoek naar de effecten van TMT interne processen en toestanden op verschillende aspecten van TMT impact. Uit dit overzicht komt als conclusie naar voren dat het noodzakelijk is om te kijken naar patronen van verschillende processen en toestanden over een langere periode voor het verkrijgen van een goed inzicht in de rol van deze processen voor team effectiviteit.

In hoofdstuk 3 is dit wat we doen. We bestuderen namelijk patronen van taakconflict, relatieconflict en vertrouwen in een steekproef van 41 besturen van studentenverenigingen in heel Nederland over een periode van tien maanden met vijf meetmomenten. We hebben gekozen voor deze specifieke steekproef vanwege de beschikbaarheid van een relatief grote groep teams met een gelijk startpunt van werken voor de periode van een jaar in dezelfde samenstelling. De resultaten geven aan dat er in teams twee duidelijke patronen zijn voor de ontwikkeling van conflict en 
vertrouwen over de tijd. De helft van de teams liet een stabiel patroon van weinig conflict en veel vertrouwen zien, terwijl de andere helft een patroon vertoonde van stijgend en relatief veel conflict en dalend, relatief weinig vertrouwen. De teams met het stabiele patroon waren effectiever dan de teams met het onstabiele patroon. Deze studie illustreert het inzicht dat wetenschappers kunnen krijgen van een temporeel perspectief op teamprocessen en ook hoe het creatief nadenken over dataverzameling kan leiden tot onverwachte mogelijkheden voor longitudinale studies over een relatief lange tijdsperiode.

TMT onderzoekers hebben aangeraden om kwalitatieve en longitudinale onderzoeksmethoden te gebruiken om een realistisch beeld te krijgen van hoe TMTs functioneren en hun organisaties beïnvloeden. Daarom heb ik gedurende een half jaar het TMT van een Nederlandse organisatie geobserveerd tijdens de wekelijkse vergaderingen en individuele interviews gehouden met de teamleden. De resultaten van dit onderzoek staan beschreven in hoofdstuk 4. De transcripten van vergaderingen en interviews zijn geanalyseerd volgens een methode van 'grounded theory' met als doel het genereren van nieuwe theoretische inzichten over TMT impact. Uit deze analyses bleek dat er een terugkerend thema was tijdens de vergaderingen van het TMT: de relatie tussen het TMT en de middenmanagers van de organisatie. De manier waarop het TMT de interactie met middenmanagers begrijpt en stuurt, wordt verklaard vanuit de literatuur over 'sensemaking' - de constructie van betekenis uit dingen die gebeurd zijn. Door de resultaten van de data-analyse te combineren met bestaande theorieën over strategisch leiderschap, sensemaking en teamprocessen, zijn we tot een theoretisch model gekomen. Dit model verbindt TMT sensemaking, TMT eenheid van handelen en TMT leiderschapsgedrag met de succesvolle implementatie van strategische beslissingen en positieve organisatieresultaten.

In hoofdstuk 5 wordt de relatie tussen TMT en middenmanagers bekeken vanuit het perspectief van de middenmanagers door te analyseren wat zij belangrijk vinden om te beoordelen of een TMT goed presteert. Onderzoekers hebben tot nu toe meestal gekeken naar de financiële resultaten van de organisatie als indicator voor TMT prestaties, ten koste van indicatoren die dichter bij het directe werk van het TMT liggen, zoals de kwaliteit van strategische beslissingen. Dit is een probleem, omdat het mogelijk heeft bijgedragen aan de inconsistente resultaten wat betreft de effecten van TMT interne processen en toestanden op uitkomsten, zoals ook in hoofdstuk 2 besproken is. In dit hoofdstuk baseren we ons op 'stakeholder' theorie en op onderzoek naar teameffectiviteit van nietmanagementteams om meer inzicht te krijgen in de multi-dimensionaliteit van TMT prestaties. Deze beide theoretische perspectieven suggereren dat het de moeite waard is om de mening van belangrijke stakeholders van een TMT te analyseren, omdat het TMT uiteindelijk van hen afhankelijk is voor het uitvoeren van strategische beslissingen. We analyseren in deze studie de verwachtingen en evaluaties van 251 middenmanagers uit Frankrijk en Nederland over de prestaties van hun TMT. Uit exploratieve en confirmatieve factor analyses blijkt dat een vijf-dimensionaal model voor TMT prestaties aannemelijk is, bestaande uit organisatieresultaten, strategisch leiderschap, verbondenheid, TMT eenheid en moreel leiderschap.

Wanneer we de resultaten van de voorgaande hoofdstukken bij elkaar nemen, lijkt het erop dat de tijd rijp is voor een nieuwe richting in het onderzoek naar de determinanten van TMT impact. Namelijk een richting waarin niet alleen wordt gekeken naar de factoren die zich binnen de 
bestuurskamer afspelen - zoals TMT interne processen en toestanden - maar vooral ook naar hoe TMTs leiding geven aan hun middenmanagers. Een eerste aanzet tot een dergelijke nieuwe richting wordt gegeven in hoofdstuk 6 door middel van een theoretisch model: het interface model van TMT en middenmanagers. Dit model bouwt op bestaand TMT onderzoek, maar heeft het potentieel om meer gedetailleerde verklaringen en empirische inzichten te geven voor TMT impact op organisaties. De twee centrale mechanismen die in het interface model worden voorgesteld zijn het uitwisselen van informatie en het in evenwicht houden van wederzijdse invloed. Deze twee mechanismen worden verondersteld beïnvloed te worden door TMT leiderschapsstijl en de zogenaamde 'volgersstijl' van middenmanagers.

Samenvattend kan ik zeggen dat dit proefschrift bijdraagt aan het begrijpen van de rol van TMTs in hun organisaties door het specificeren van temporele patronen van interne teamprocessen en door het introduceren van een focus op TMT leiderschap van middenmanagers. Hierdoor kunnen TMT onderzoekers in het vervolg meer gedetailleerde modellen formuleren over TMT impact en daardoor mogelijk ook de huidige inconsistente onderzoeksresultaten beter begrijpen. TMTs zelf, alsmede hun adviseurs en trainers, kunnen van dit proefschrift profiteren door in te zien dat de invloed van TMTs op hun organisaties niet alleen binnen, maar juist ook buiten de bestuurskamer wordt uitgeoefend. 


\section{About the Author}

Anneloes Raes was born on October 27, 1979 in Raamsdonksveer, the Netherlands. In 1992, she started her high school education at Newmancollege in Breda, obtaining her gymnasium degree in 1998. She studied Psychology at the Katholieke Universiteit Nijmegen - now named Radboud University - where she graduated in Work and Organizational Psychology in November 2003 with the qualification 'cum laude'. In September 2000, she put her studies on hold for a year to work as a journalist and chief editor for the student newspaper ANS.

In January 2004, she started her PhD research at the Department of Organization and Strategy of Maastricht University. Between January and April 2006, she was a visiting PhD student at the University of California Los Angeles (UCLA) Anderson School of Management, and in the period of April to August 2007, she was a visiting PhD student at Harvard University in the department of Psychology. In May 2008, Anneloes started working as a senior research fellow at the University of St. Gallen's Institute for Leadership and Human Resource Management in Switzerland. 